\title{
THE PETROLOGY, GEOCHEMISTRY AND GEOCHRONOLOGY OF BACK-ARC STRATOVOLCANOES IN THE SOUTHERN KERMADEC ARC-HAVRE TROUGH, SW PACIFIC
}

Alexander D.C. Zohrab

A thesis submitted to Victoria University of Wellington in partial fulfilment of the requirements for the degree of Master of Science in Geology

Victoria University of Wellington

School of Geography, Environment and Earth Sciences

Wellington, New Zealand 



\section{Frontispiece}

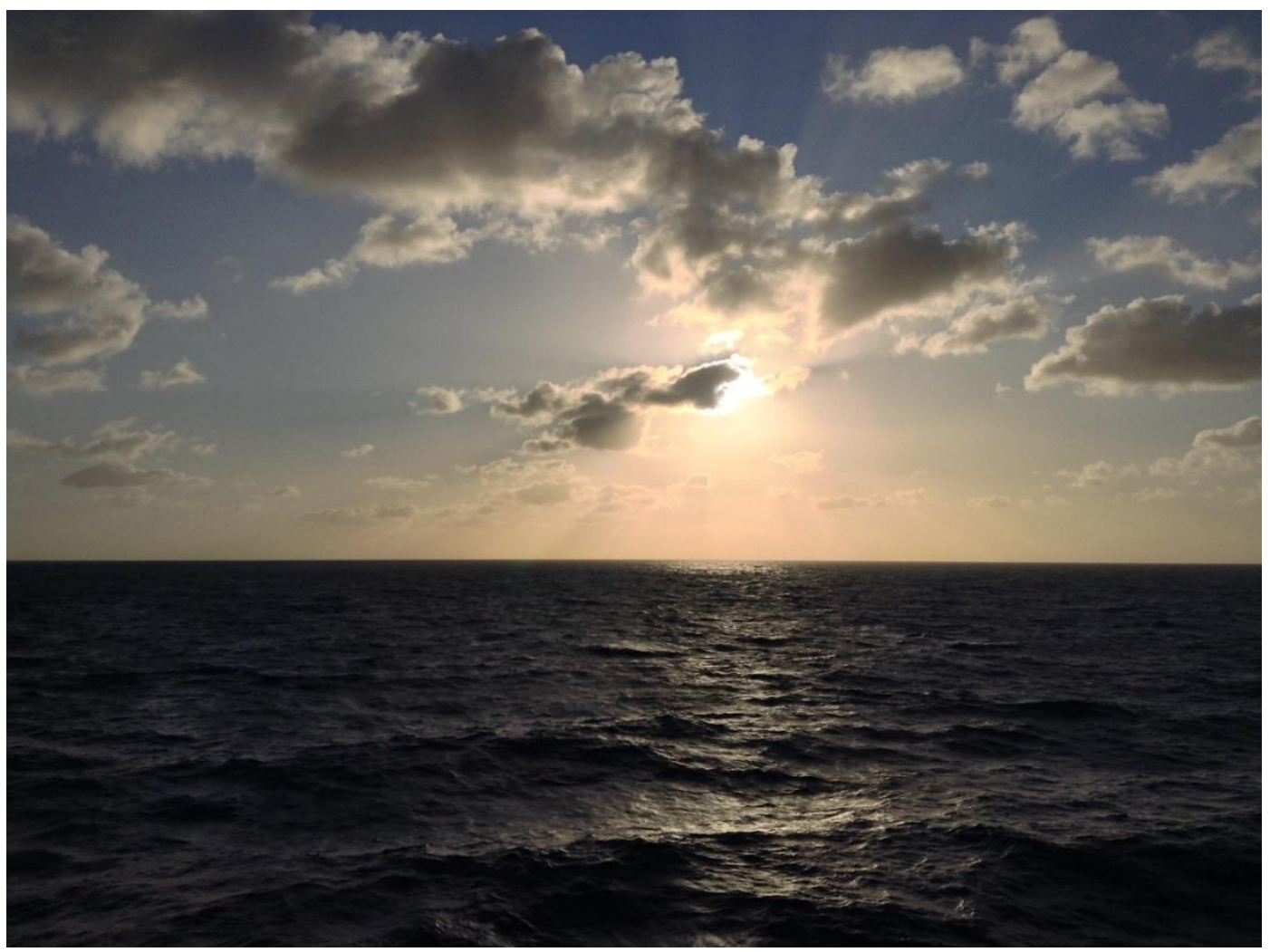

View of the Pacific Ocean above the Kermadec Arc, image taken during the R/V Tangaroa TAN1513 in 2015. 



\section{Abstract}

The Kermadec Arc-Havre Trough (KAHT) is widely regarded as a classical example of an intra-oceanic arc-back-arc system, where subduction-driven arc magmatism is focused at the Kermadec volcanic arc-front, and magmatism within the Havre Trough back-arc system results from decompression-related melting. In detail, however, the Havre Trough has not been well-studied, and data for very few lavas have been reported.

Recent mapping undertaken in the southern Havre Trough has resulted in the discovery of several prominent submarine stratovolcanoes, Gill Seamount, Rapuhia Seamount and the related Rapuhia Ridge, Yokosuka Seamount, and Giljanes Seamount, situated in the middle of deep rifts and on elevated crustal plateaux. The origin and evolution of these stratovolcanoes is unknown. The first detailed dataset of whole rock major and trace element geochemistry, mineral chemistry, and ${ }^{40} \mathrm{Ar} /{ }^{39} \mathrm{Ar}$ isotope data, for lavas erupted from these volcanoes is presented here, and used to investigate the processes that drive volcanism in the Havre Trough back-arc.

${ }^{40} \mathrm{Ar} /{ }^{39} \mathrm{Ar}$ ages obtained from back-arc stratovolcanoes range from ca. 1167 953 ka for Gill Seamount, and ca. 107 - 50 ka for Rapuhia Ridge. These ages overlap with known ages for arc-front lavas, indicating that both back-arc and arc-front volcanism are coeval. These ages are all significantly younger than the inferred initation of Havre Trough rifting ca. 5 - 6 Ma.

Lavas analysed from Gill Seamount and Rapuhia Ridge are basaltic to basalticandesitic in whole rock composition and contain a phenocryst assemblage of olivine \pm orthopyroxene + clinopyroxene \pm plagioclase. Lavas from Rapuhia Seamount, Yokosuka Seamount and Giljanes Seamount range from andesitic to dacitic in composition, and have a phenocryst assemblage consisting primarily of plagioclase \pm clinopyroxene \pm amphibole $\pm \mathrm{Fe}$-Ti oxides \pm apatite. Variations in mineral assemblages and whole rock compositions of the lavas are consistent with crystal fractionation of their respective phenocryst phases. The more evolved compositions of Rapuhia Seamount, Yokosuka Seamount and Giljanes Seamount, all sited on an 
elevated crustal plateau, are inferred to result from prolonged assimilation + fractional crystallisation (AFC) in the mid- to upper- crust.

Mineral compositions provide additional evidence for fractional crystallisation, and most crystals are inferred to have crystallised in equilibrium with their host melt. However, compositions of some olivine phenocrysts in Gill Seamount and Rapuhia Ridge indicate multiple populations of olivine, suggesting their magmatic systems were open to contributions from secondary processes. Variations in Or content in plagioclase crystals for a given lava suite suggests the sample suites crystallised from melts with different starting $\mathrm{K}_{2} \mathrm{O}$ compositions.

Elevated ratios of $\mathrm{Nb} / \mathrm{Yb}$ in the mafic Gill Seamount and Rapuhia Ridge lavas indicate the back-arc volcanoes and ridges originated from a less depleted mantle than that present underneath the Kermadec volcanic arc-front, likely a consequence of trenchward advection of mantle within a suprasubduction wedge and/or partial melting of a fusible enriched mantle component.

All whole rock samples from these back-arc volcanoes have trace element characteristics that resemble those of typical volcanic arc magmas, indicating that they are variably modified by subducting plate-derived components despite their rear-arc setting. However, the extent of fluid enrichment is less than that at the Kermadec volcanic arc-front. Elevated REE patterns and $(\mathrm{La} / \mathrm{Sm})_{\mathrm{N}}$ ratios suggest the subductioncomponent modifying back-arc volcano magmas is dominated by subducting sediment. This sediment component is not consistent with aqueous fluid transfer or bulk mixing, but by the addition of a sediment-derived partial melt with residual accessory phases monazite + zircon + rutile. HFSE/REE fractionated trace element patterns overlap for unmodified basalts from Gill Seamount and Rapuhia Ridge, and Rumble V Ridge back-arc constructional volcanism to the south. This suggests that a similar mechanism triggers constructional back-arc volcanism at both locations in the southern Havre Trough, likely a consequence of thermal anomalies inferred to be present in the mantle wedge (Todd et al. (2011)). 


\section{Acknowledgements}

My thesis is complete! As with any thesis, this research resulted from a collarobative effort from a number of people expertising in a vast array of disciplines, techniques and understanding of different fundamental aspects vital for the success of the project. I have received an incredible amount of support and guidance from a lot of people, who have made my time undertaking this research so incredibly rewarding and fulfilling. There are a many people I have to thank.

First, I owe a big thank you to my three awesome supervisors. Thank you all for organising and allowing me to work on what has truly been a fascinating and exciting research project! To my primary supervisor, Monica Handler, thank you for all your help with discussing various aspects of the project, especially regarding sample preparing and ICP-MS analysis in the geochemistry laboratory. You were always available and willing to listen in on my progress regarding any part of my research, from sample cleaning to geochemical processes, which I am extremely grateful for. Your planning regarding constructing and organising ideas and thoughts with the discussion was invaluable. Richard Wysoczanski, thank you for providing the samples for the project, and for being so welcoming whenever I visited NIWA. I am extremely grateful for all your help with the major element analyses and bathymetric maps, and of course for the opportunity to participate the Tangaroa voyage, an experience I will never forget! Christian Timm, thank you for providing the funding for the Ar/Ar analyses, and for all your input on the mineral data! Your feedback helped clarify some very important ideas and processes, which I am very thankful for! Thank you guys again for taking me on, and especially for reviewing and providing feedback on all my written (and very late!) material. And thank you guys for providing some very critical unpublished data!

NIWA and GNS are both thanked for providing funding for the project.

I would not have obtained anywhere as high a quantity or quality of a dataset without the technical support from a wide number of people. Thanks goes to Stewart Bush, for preparing thin sections, Julie Vry, for assistance with using the Optical microscope, Dez Tessler, for providing conductivity meters, Jane Chewings, for providing resources in the sedimentology and volcanology labs, and storage for my (many!) boxes of samples, Sabrina Lange, for help with sample preparation, Bruce Charlier, for help with running/tuning the ICP-MS, Spectrachem, for preparing glass disks for major element analysis, Ian Schipper, for help with EPMA analysis, and Graham Leonard and Andrew Calvert, for analysing the samples for Ar/Ar analysis. Graham is especially thanked for help with funding, sample selection and especially for instilling in me some very critical efficiency skills!

I would also like to thank the scientific team and crew who participated in the $R / V$ Tangaroa TAN1513 'SAMSARA' voyage. It was truly one of the greatest and most unforgettable experiences of my life!

To the senior VGP students, Elliot, Celine, Leo, and Chris (Condor) Conway, thank you for all your advice regarding sample preparation, EPMA analysis, and for always being receptive of any concerns I had regarding research techniques at any stage of the project. Condor is especially thanked for helping with the sample preparation for Ar/Ar dating, and for showing me the ins and outs of dealing with submarine rocks. 
Thank you to all the other post-grad students who I have been studying with throughout these years, especially Matt, Juergen, Marcel, Hines, Steve, Webber, Cam, Kraus, Keys, Ben, Olya and Anya. You guys have all ensured that my time studying geology at Victoria so incredibly fun and enjoyable. Thanks to all other staff and post-grads at Vic who have taught and helped me in some form or another whilst I've been studying here. There are many of you.

I owe a big thank you to all the office crew in $\mathrm{CO} 421$, who have all been exceptionally friendly, and with lots of communal banter and occasional venting (mainly from me..). In particular I would like to thank Aidan, Josh, Lauren, Emily, Andrea, Hannah, and Gracie. Thank you all for looking out of me and helping me stay positive when at times it seemed like all was lost. Gracie (my academic sister) is especially thanked for help and provision of adobe illustrator, suggestions for formatting and editing the parts of the thesis, and of course for all the many good yarns about research and academic life. Your passion and enthusiasm for science and research is contagious.

I am especially thankful of Condor and Gracie for proof reading parts of my written material and providing valuable feedback to help important ideas. Discussions with John Gamble helped clarify some very important points and gave valuable suggestions for portraying figures and geochemical data.

To all the legends whom I have lived with on Kelburn Parade, Matt, Elliot, Swhite, Seaston, Kate, Johnny, and Tim, thank you all for making my time living here so unbelievably fun and enjoyable, and simply a blast! You guys never failed to entertain and put a smile on my face. Many more adventures are waiting!

Finally, I would like to thank my family. Thank you to Helen, Denise, Ian, Michelle, Alan, Marie. I am very thankful of all the hospitality you guys have provided through all these years. I promise I'll be more in touch in the future... To Irene, Teddy, Karl, Anya, and Isabella, thank you all for all of your encouragement and support.

This thesis is dedicated to my two lovely parents, Lesley and John. There is no way I would have been able to have done any this without all of your love, advice, encouragement and especially for all of your support throughout all these years. You have both taught me how to work hard, aim high, embrace challenges, never give up regardless of the situation, and especially for always encouraging me to follow my dreams and passions. You have no idea how much I love this work. Thank you guys for everything. 


\section{Table of Contents}

Frontispiece

Abstract .........................................................................................................................................

Acknowledgements ...................................................................................................................... iii

Table of Contents ................................................................................................

List of Figures ............................................................................................................. vii

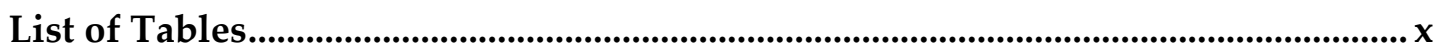

Chapter 1: Introduction............................................................................................................... 1

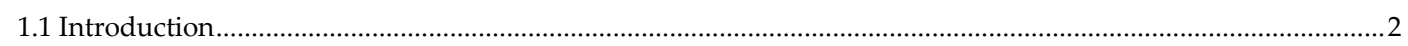

1.2 Back-Arc Volcanism in Intra-Oceanic Arc Systems ....................................................................................

1.3 Back-Arc Volcanism in the Southern Kermadec Arc-Havre Trough.....................................................................

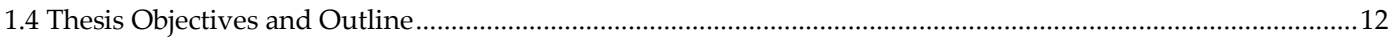

Chapter 2: Geological Setting and Sample Locations ............................................................ 16

2.1 The Kermadec Arc-Havre Trough Subduction System: An Overview ...............................................................17

2.2 Background to Magmatism at the Kermadec Convergent Margin..........................................................................22

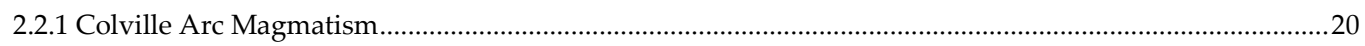

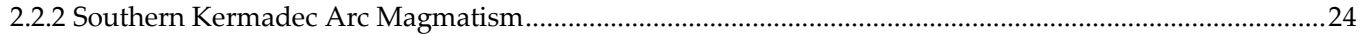

2.3 Back-Arc Extension in the Southern Kermadec Arc-Havre Trough ...................................................................27

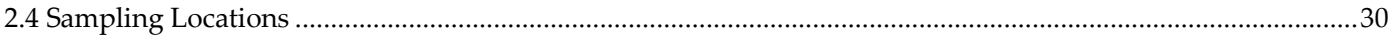

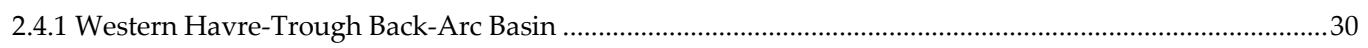

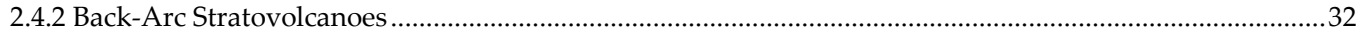

Chapter 3: Analytical Techniques .............................................................................................. 37

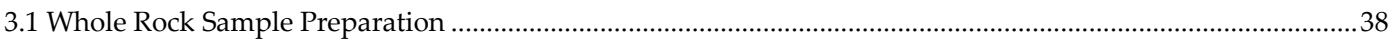

3.2 Whole Rock Major Element Geochemistry Analysis............................................................................................39

3.3 Whole Rock Trace Element Geochemistry Analysis.......................................................................................... 40

3.3.1 Laboratory Protocol and Beaker Preparation.................................................................................................... 40

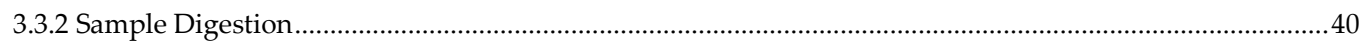

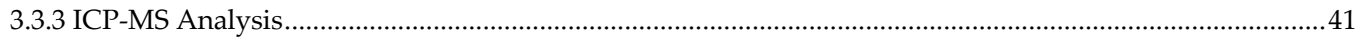

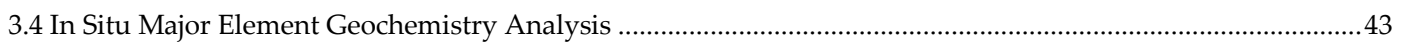

3.5 Mineral Separate Geochronology Analysis ...................................................................................................... 45

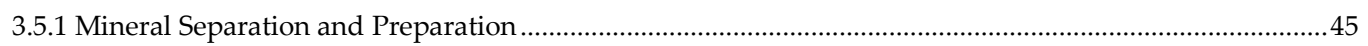

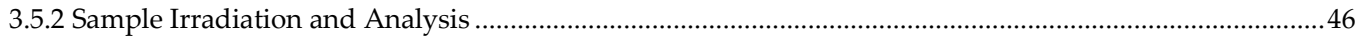




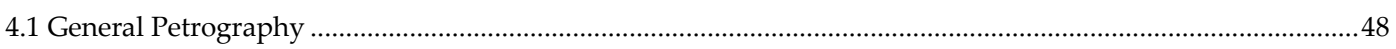

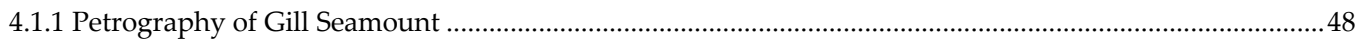

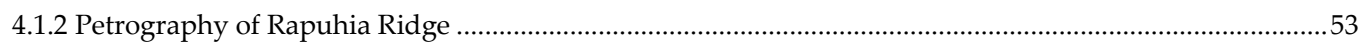

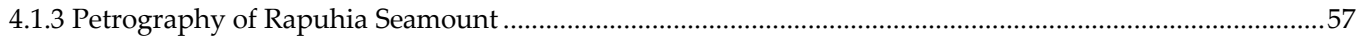

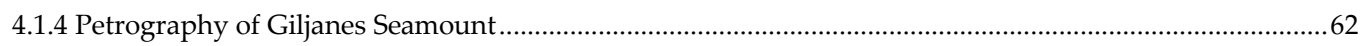

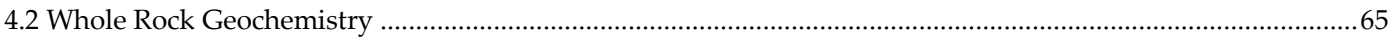

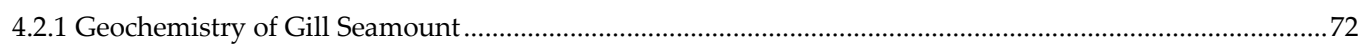

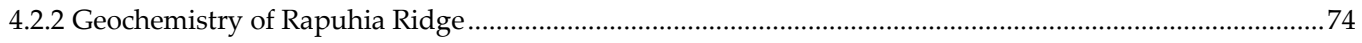

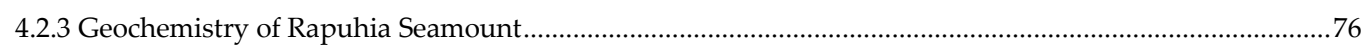

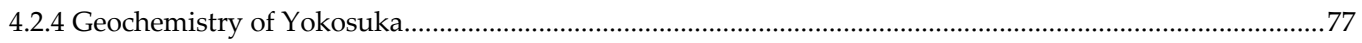

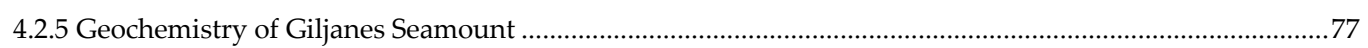

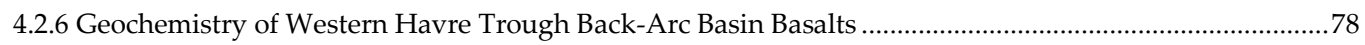

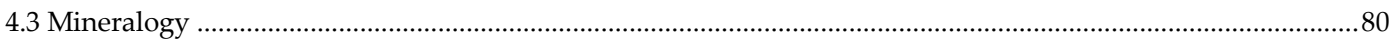

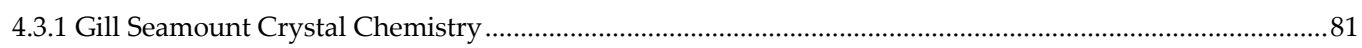

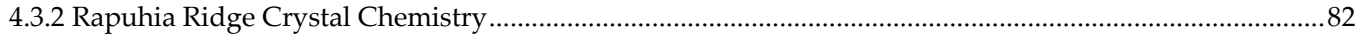

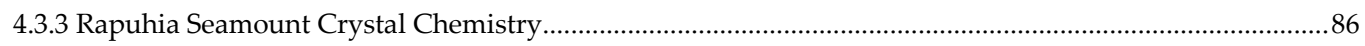

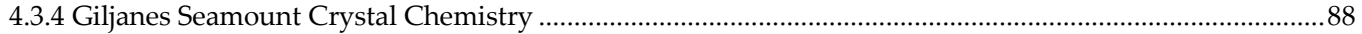

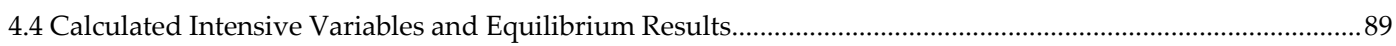

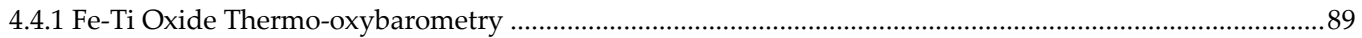

4.4.2 Amphibole Geothermobarometry and Hygrometry ................................................................................90

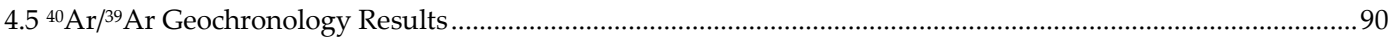

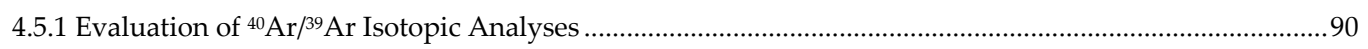

4.5.2 ${ }^{40} \mathrm{Ar} /{ }^{39} \mathrm{Ar}$ Geochronology of Gill Seamount and Rapuhia Ridge........................................................92

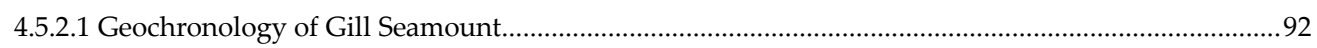

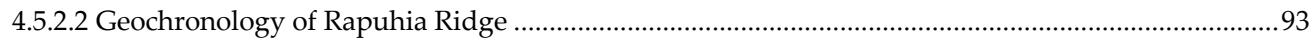

Chapter 5: Discussion .................................................................................................................... 94

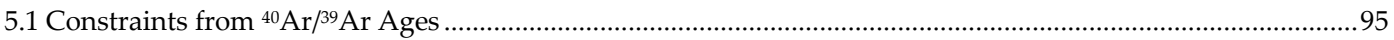

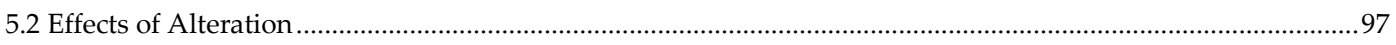

5.3 Magmatic Processes for Back-Arc Volcanoes in the Southern Kermadec Arc ...............................................98

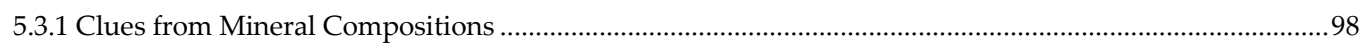

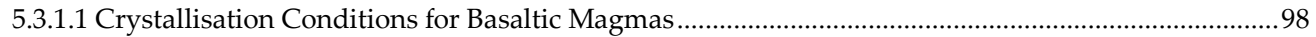

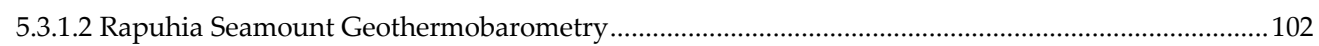

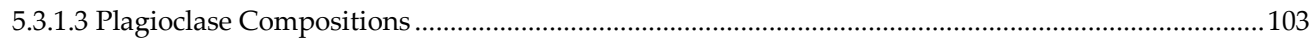

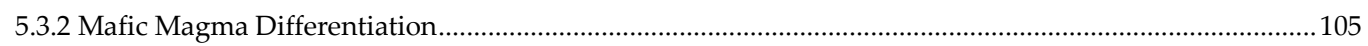

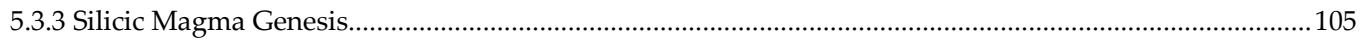

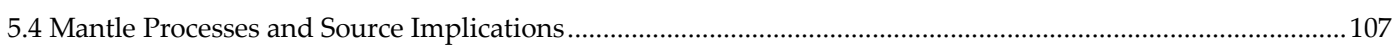

5.4.1 The Southern Havre Trough Ambient Mantle Wedge............................................................................109

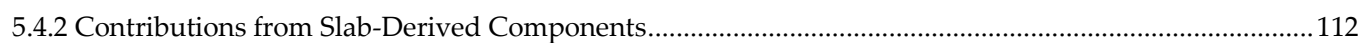

5.4.2.1 The Role of Fluid Transfer from the Subducting Slab ..............................................................113 


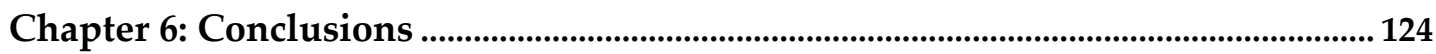

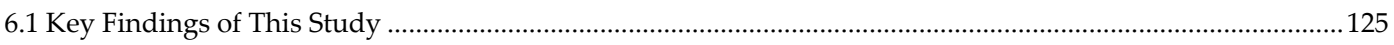

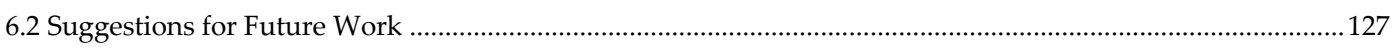

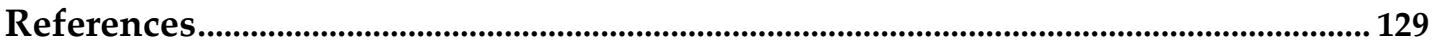

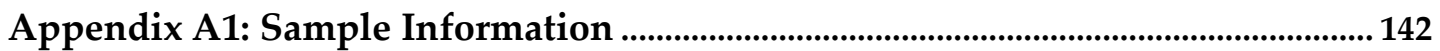

Appendix A2: Representative Petrographic Descriptions .............................................. 144

Appendix A3: Analytical Standards and Uncertainties................................................. 153

Appendix A4: Additional EPMA Information ....................................................163

\section{Electronic Appendices}

EA1. Whole Rock Major Oxide and Trace Element Data

EA2. BSE Images

EA3. EPMA

EA4. Geothermobarometry 


\section{List of Figures}

\section{Chapter 1}

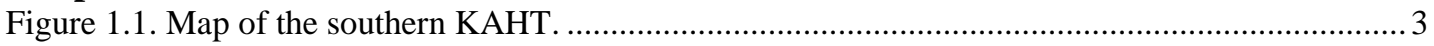

Figure 1.2 Schematic model for subduction zone magmatism in the southern KAHT. ....................... 6

Figure 1.3. Plots showing the relationship of whole rock and plagioclase compositions of samples

from the Colville Arc, Kermadec Arc-front, and Havre Trough Back-Arc Basins.....

\section{Chapter 2}

Figure 2.1. Regional setting of the southern Kermadec Arc-Havre Trough.

Figure 2.2. Plots showing the relationship of whole rock and plagioclase compositions between

Colville Arc, Kermadec Arc-front, and Havre Trough analyses.

Figure 2.3. Plots showing the relationships between total subduction components and source depletion for lavas from the Colville Arc, Kermadec Arc-front volcanoes, and Havre Trough Back-arc basins.23 Figure 2.4. Digital topographic maps of the ocean floor between the Kermadec Ridge and the Colville

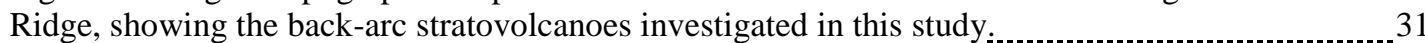

Figure 2.5. Map of Gill Seamount, in the southern KAHT.

\section{Chapter 4}

Figure 4.1. Photomicrographs in cross-polarised light of selected clinopyroxene phenocrysts in various samples from Gill Seamount. 49

Figure 4.2. Photomicrographs of representative plagioclase phenocrysts in various samples from Gill

Seamount, in cross-polarised light.

Figure 4.3. Photomicrographs of selected olivine phenocrysts from Gill Seamount, in cross-polarised light.

Figure 4.4. Photomicrographs of crystalline groundmass from Gill Seamount. ............................52 Figure 4.5. Examples of the effect of amygdales on physical appearance of rock specimens from the TAN1007-012 suite from Gill Seamount.

Figure 4.6. Photomicrographs in cross-polarised light of representative olivine phenocrysts in samples from Rapuhia Ridge.

Figure 4.7. Photomicrographs in cross-polarised light of pyroxene phenocrysts from selected samples

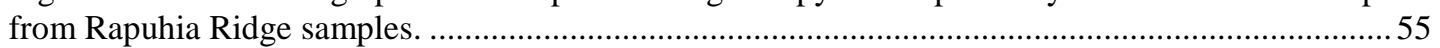

Figure 4.8. Photomicrographs of crystalline groundmass from Rapuhia Ridge...............................56 Figure 4.9. Photomicrographs in cross-polarised light of plagioclase phenocrysts in various samples from Rapuhia Seamount

Figure 4.10. Photomicrographs of amphibole phenocrysts in cross-polarised light from TAN0205-101 lavas from Rapuhia Seamount.....

Figure 4.11. Examples of clinopyroxene, apatite, and Fe-Ti oxides in various samples from Rapuhia Seamount.

Figure 4.12. Photomicrographs of xenolith fragments from Rapuhia Seamount, in cross-polarised

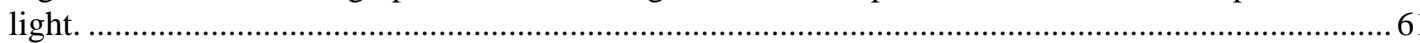

Figure 4.13. Photomicrographs of crystalline groundmass from Rapuhia Seamount. ....................... 61 Figure 4.14. Photmicrographs of plagioclase phenocrysts from sample TAN0205-100-03, from

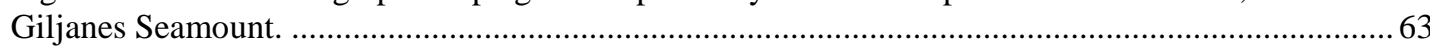
Figure 4.15. Photomicrographs of clinopyroxene and amphibole phenocrysts from sample TAN0205100-03, from Giljanes Seamount, in cross-polarised light. ..................................................... 64 Figure 4.16. Photomicrographs of framework groundmass of sample TAN0205-100-03 from Giljanes Seamount, showing the same area in a), plane-polarised light, and in b) cross-polarised light. ..........64 Figure 4.17. Plots showing whole rock wt $\%$ of a) total alkali, b) $\mathrm{FeO} * / \mathrm{MgO}$, and c) $\mathrm{K}_{2} \mathrm{O}$ against $\mathrm{SiO}_{2}$, for back-arc lavas investigated in this study................................................................6 66 Figure 4.18. Plots of a) $\mathrm{K}_{2} \mathrm{O}$ versus $\mathrm{SiO}_{2}$. Plots b) to e) are of $\mathrm{Ni}, \mathrm{Hf}, \mathrm{Cr}$, and $\mathrm{Zr}$, plotted against $\mathrm{MgO}$.

Figure 4.19. N-MORB normalised Multi-element plot of TAN1007-012 and TAN1007-011 samples from Gill Seamount. 
Figure 4.20. N-MORB normalised Multi-element plot plot of TAN1007-015 and TAN1007-016 samples from Rapuhia Ridge

Figure 4.21. N-MORB normalised Multi-element plot of TAN1007-014 and TAN0205-101 samples from Rapuhia Seamount.

Figure 4.22. N-MORB normalised Multi-element plot of TAN0205-102 (Yokosuka) and TAN0205-

100 (Giljanes) samples.

Figure 4.23. Major oxide plots of a) $\mathrm{FeO}^{*}$ b) $\mathrm{TiO}_{2}$, c) $\mathrm{CaO}$, d) $\mathrm{P}_{2} \mathrm{O}_{5}$, e) $\mathrm{Na}_{2} \mathrm{O}$, f) $\mathrm{Al}_{2} \mathrm{O}_{3}$, and g) $\mathrm{SiO}_{2}$, versus $\mathrm{MgO}$.

Figure 4.24. Chondrite-normalised REE plots for samples from Gill Seamount. ............................ 74

Figure 4.25. Chondrite-normalised REE plots for samples from Rapuhia Ridge. ........................... 75

Figure 4.26. REE chondrite-normalised values for TAN0205-101 and TAN1007-014 samples from

Rapuhia Seamount. ................................................................................................ 77

Figure 4.27. REE chondrite-normalised plot for samples from Yokosuka Seamount (TANO205-102)

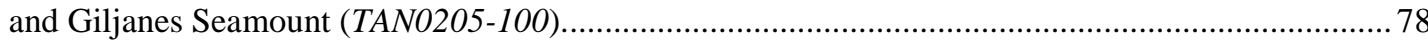

Figure 4.28. Multi-element N-MORB-normalised plot for Western Havre Trough BABB samples... 79

Figure 4.29. Plot showing the relationship between Olivine forsterite content and whole rock $\mathrm{Mg \#}$ for

samples analysed from Gill Seamount.

Figure 4.30. Plots of a) clinopyroxene from TAN1007-012 samples, b) clinopyroxene analyses from TAN1007-011 samples, and c) Orthoclase (Or) versus Anorthite (An) content of plagioclase from Gill Seamount.

Figure 4.31. Plots showing olivine compositions of samples from Rapuhia Ridge. ......................... 84

Figure 4.32. Plots of Rapuhia Ridge mineral compositions. .................................................... 85

Figure 4.33. Plots showing compositions of clinopyroxene and plagioclase crystals from Rapuhia Seamount.

Figure 4.34. Plot of Orthoclase (Or) against Anorthite (An) content for plagioclase from sample

TAN0205-100-03 from Giljanes

Figure 4.35. Plots of age spectra and isochron diagrams for a) 012-01, b) 011-04, c) 015-04, and d) 016-01.

\section{Chapter 5}

Figure 5.1. Plots of clinopyroxene compositions from Gill Seamount and Rapuhia Ridge.

Figure 5.2. Plot showing compositions of crystals in chemical equilibrium with the host melt, and accumulation for olivine phenocrysts, from Gill Seamount and Rapuhia Ridge. ........................... 100 Figure 5.3. Plots of a) $\mathrm{MgO}$ and b) $\mathrm{TiO}_{2}$ versus $\mathrm{SiO}_{2}$, for compositions of amphibole crystals from Rapuhia Samount, dredge TAN0205-101 ............................................................................. 102 Figure 5.4. Plot of Orthoclase (Or) versus versus Anorthite (An) for plagioclase crystals from the Colville Arc, Rumble II West, Rumble II East, Kermadec Arc-front, Gill Seamount, Rapuhia Seamount, Rapuhia Ridge, and Giljanes Seamount 104 Error! Bookmark not defined. Figure 5.5. Plot showing the relationship between $\mathrm{Nb} / \mathrm{Yb}$ and distance from Kermadec arc-front. 110 Figure 5.6. Plot of $\mathrm{Th} / \mathrm{Yb}$ versus $\mathrm{Nb} / \mathrm{Yb}$.

Figure 5.7. Plots of a) $\mathrm{Ba} / \mathrm{Nb}$, and b) $\mathrm{Ba} / \mathrm{Th}$ versus $(\mathrm{La} / \mathrm{Sm})_{\mathrm{N}}$, for lavas from Gill Seamount, Rapuhia Ridge, the Rumble V Ridge, Kermadec Arc-front volcanoes, and Havre-Trough Back-arc basins ..... 113 Figure 5.8. Plot of $\mathrm{Th} / \mathrm{La}$ vs $\mathrm{Sm} / \mathrm{La}$, showing the effect of sediment mixing between bulk KAHT sediment and depleted MORB mantle.

Figure 5.9. Plots of a) $\mathrm{Hf}^{*} / \mathrm{Hf}^{*}$ versus $\mathrm{Th} / \mathrm{Yb}$, and $\mathrm{b}$ ) $\mathrm{Th} / \mathrm{Yb}$ versus $\mathrm{Nb} / \mathrm{Yb}$.

Figure 5.10. Plot of $\mathrm{MgO}$ (wt \%) versus $\mathrm{SiO}_{2}$ (wt \%), for analyses of samples from Gill Seamount, Rapuhia Ridge, Rapuhia Seamount, Yokosuka Seamount, Giljanes Seamount, Western Havre Trough Back-arc basins, Kermadec Arc-front Volcanoes, Havre Trough Back-arc basins, and the Colville Arc.

\section{Appendix A2}

Figure A2.1. Photographs and micrographs of samples from back-arc stratovolcanoes 


\section{List of Tables}

\section{Chapter 1}

Table 1.1. Recent marine research voyages that have been undertaken in the KAHT

\section{Chapter 2}

Table 2.1. Stratovolcanoes investigated in this study

\section{Chapter 3}

Table 3.1. Samples selected for high precision ${ }^{40} \mathrm{Ar} /{ }^{39} \mathrm{Ar}$ isotope analysis

\section{Chapter 4}

Table 4.1. Samples selected for electron probe micro analysis.

Table 4.2. Ages and Uncertainties obtained for each sample selected for ${ }^{40} \mathrm{Ar} /{ }^{39} \mathrm{Ar}$ isotope analysis.. 92

\section{Chapter 5}

Table 5.1. Range of Forsterite content of olivine phenocrysts that crystallised in equilibrium with the host melt from each sample from Gill Seamount and Rapuhia Ridge shown in Figure 5.2

Table 5.2. Temperature estimates for Gill and Rapuhia obtained using the method of Danyushevsky and Sobolev (1994).

Table 5.3. List of Mineral/melt partition coefficients for accessory mineral phases present in subducting sediment at the southern Kermadec Arc, modelled by Todd et al. (2010).

\section{Appendix A1}

Table A1.1. List of Samples investigated in this study

\section{Appendix A3}

Table A3.1 Precision and accuracy of internal standards used during XRF analysis.

Table A3.2. List of preferred values for element abundances of whole rock powdered standards BHVO-

2 and BCR-2 used for trace element solution ICP-MS analysis.

Table A3.3. Summary of trace element data obtained for USGS international standard BCR-2. 1156

Table A3.4. Summary of trace element data obtained for duplicate dissolutions of samples TAN1007-

011-06 and TAN1007-011-03, providing estimates of the reproducibility of ICP-MS analyses.

Table A3.5. Summary of trace element data obtained for duplicate dissolutions of samples TAN1007-

011-11, providing estimates of the reproducibility of ICP-MS analyses.

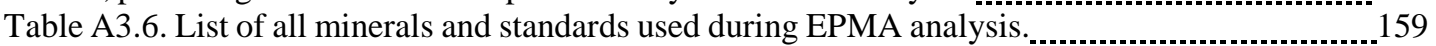

Table A3.7 Summary of EMPA data acquired for mineral standards.

\section{Appendix A4}

Table A4.1 Summary of measurement times and average counts for each element during EPMA analysis of standards 




\section{Chapter 1: \\ Introduction}




\subsection{Introduction}

Magmatism at subduction zones occurs as a result of volatile fluxing in the mantle at convergent margins, and is typically formed along arcuate chains of arcfront volcanoes (Gill, 1981; Wallace, 2005; Wysoczanski et al., 2006). Located behind the volcanic arc-front on the overriding plate, back-arc volcanoes can provide valuable information regarding processes that contribute to compositional heterogeneity within the mantle wedge (Hochstaedter et al., 2000, 2001; Tollstrup et al., 2010). Analyses of the erupted lavas of back-arc volcanoes have revealed compositions that are generally similar to those of arc-front magmas (e.g. Hochstaedter et al., 2000, 2001; Tollstrup et al., 2010), suggesting that they are also the surficial expression of partial melting in the mantle wedge as a result of the release of fluid-derived components from the subducting slab. However, the extent to which slab-derived components are transferred from the subducting slab and interact with the convecting mantle in the back-arc to facilitate arc magmatism is not well understood, and remains a matter of interest and considerable debate. The Kermadec Arc-Havre Trough (KAHT) (Figure 1.1) is a young intra-oceanic, active arc-back-arc system, located in the southwest Pacific Ocean, and provides an excellent opportunity to investigate back-arc petrogenesis (Ruellan et al., 2003).

The majority of studies that have investigated magmatically-driven processes in the KAHT have involved the use of marine research voyages to explore localised regions in detail. These studies have focused primarily on the volcanoes of the Kermadec Arc volcanic-front, and in comparison there has been relatively limited exploration undertaken in the Havre Trough back-arc rift system (Wysoczanski and Clark, 2012). Thus the evolution of the Havre Trough, in particular the nature and timing of onset of back-arc extension, is poorly constrained. In recent years, detailed surveying of the southern Havre Trough has resulted in the discovery of large backarc stratovolcanoes in the southern Havre Trough (e.g 40-55 $\mathrm{km}^{3}$ in volume) (Wright et al., 2006; Wysoczanski et al., 2010), situated in both deep basins and on elevated basal plateaux. The magmatic processes associated with the formation of stratovolcanoes in these regions of the Havre Trough back-arc are investigated in this thesis, by examining a suite of lavas that have erupted from a series of stratovolcanoes, Gill Seamount, Rapuhia Seamount, Rapuhia Ridge, Yokosuka Seamount and Giljanes 
Seamount that are situated in the southern Havre Trough, and are aligned in a profile orthogonal to the Kermadec Arc-front at $\sim 34.5^{\circ} \mathrm{S}$ (Figure 1.1).

The primary aim of this study is to constrain the origin and evolution of backarc volcanism in the southern KAHT, by carrying out the first detailed petrological and geochemical study on lavas erupted from these four back-arc stratovolcanoes.

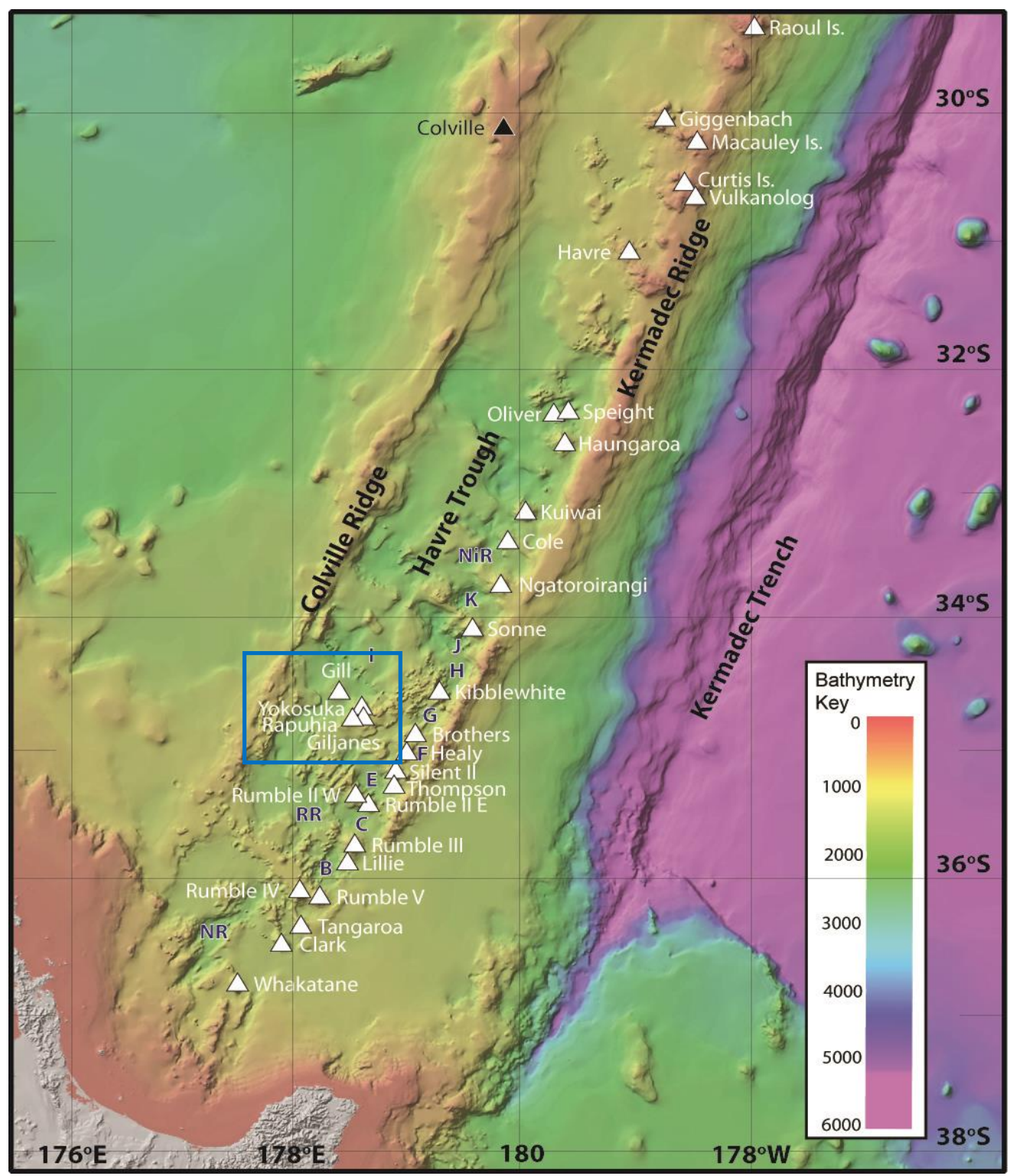

Figure 1.1. Map of the southern KAHT.

All Kermadec Arc-front volcanoes are shown in white triangles, labelled in white, and all Colville Arc volcanoes are shown in black triangles, labelled in black. Havre Trough back-arc basins are labelled with blue abbreviations. The Colville Ridge, Havre Trough, Kermadec Ridge, and Kermadec Trench are labelled in black text. The main stratovolcanoes investigated in this study are shown in blue rectangle. Image courtesy of NIWA. 


\subsection{Back-Arc Volcanism in Intra-Oceanic Arc Systems}

Since early studies confirmed the links between convergent margins and arc volcanism (e.g. Dickinson and Hatherton, 1967), and between extension and back-arc basins (e.g. Karig, 1970), seminal models for arc-back-arc systems predicted arc volcanism to occur within a confined region parallel to the subduction zone, where the underlying subducting plate is 100-130 km deep (e.g. Gill, 1981; Tatsumi et al., 1986; Syracuse and Abers, 2006), and for magmatism in the back-arc region behind the arc front, on the overriding plate, to be driven predominantly by extension (e.g. Weissel et al., 1981; Martinez and Taylor, 2006). It was not until the discovery of volcanic constructs within the back-arc region behind the northern Mariana Arc, (e.g. Hussong and Fryer, 1983), that it became evident that studies and models needed to be refined to explain the occurrence of constructional back-arc volcanoes and relate their magmatic evolution to that of coincident volcanic arc-front and back-arc basins. As a result of ongoing marine studies, back-arc volcanoes have been discovered in multiple regions within arc-back-arc systems, and generally form associations of individual stratovolcanoes or ridges oriented orthogonal to the volcanic arc front (e.g. Stern et al., 1993, 2006; Martínez et al., 1995; Wright et al., 1996).

Detailed geochemical analyses have confirmed that back-arc magmas have similar compositions to arc front magmas, confirming they originate from partial melting as a result of the transfer of slab-derived components into the ambient mantle wedge (Stern et al., 1993, 2006, 2014; Ryan et al., 1995; Hochstaedter et al., 2000, 2001; Machida and Ishii, 2003; Tollstrup and Gill, 2005; Duggen et al., 2007; Portnyagin et al., 2007; Machida et al., 2008; Todd et al., 2010, 2011; Tollstrup et al., 2010). Their back-arc setting reflects the juxtaposition of an arc magma source within an extension-dominated regime. A number of studies have been undertaken to investigate and constrain the origin and evolution of back-arc volcanoes (e.g. Stern et al., 1993, 2006; Woodhead et al., 1993; Hochstaedter et al., 2000, 2001; Machida and Ishii, 2003; Pearce et al., 2005; Portnyagin et al., 2007; Machida et al., 2008; Todd et al., 2010, 2011), in particular how their magmatic processes relate to other magmatic and tectonic processes associated with arc-back-arc systems. Recent work has been undertaken to constrain how subduction processes modify the compositions of backarc melts, in particular the nature and composition of the subducting components 
(Hochstaedter et al., 2001; Todd et al., 2010; Tollstrup et al., 2010), the extent to which the subducting components interact with the convecting mantle (Pearce et al., 2005; Tollstrup and Gill, 2005; Pearce and Stern, 2006; Duggen et al., 2007; Machida et al., 2008), magma differentiation after partial melting and before eruption (Machida and Ishii, 2003; Stern et al., 2014), and pre-existing heterogeneity in the ambient mantle (Hochstaedter et al., 2000; Todd et al., 2011).

Oceanic arc volcanism occurs at convergent margins where the two colliding plates are composed of oceanic lithosphere and there is subduction of one oceanic plate beneath the other (Gill, 1981). Magma generation beneath the volcanic arc front occurs as a result of partial melting in the mantle wedge after it has been hydrated with components derived from the subducting slab, which lower the solidus of mantle peridotite (Tatsumi et al., 1983, 1986; McCulloch and Gamble, 1991; Hattori and Guillot, 2003). As the subducting slab, which is composed of oceanic lithospheric mantle, altered oceanic crust, and a sediment veneer, descends to greater depths, aqueous fluids and silicate melts are released from the down-going slab and into the mantle wedge (Schmidt and Poli, 1998; Mibe et al., 1999) (Figure 1.2). These components initially form a layer of serpentinite, which then gets dragged down and subsequently dehydrates and releases the slab-derived components into the mantle wedge at greater depths (Hattori and Guillot, 2003; Wysoczanski et al., 2006) (Figure 1.2). However, if the subducting slab is relatively cold, and/or if the geothermal gradient is shallower, water can be retained in the oceanic crust and serpentinised mantle and the slab-derived components can be released at greater depths (Rüpke et al., 2004). More comprehensive reviews for subduction zone magmatism are outlined in Gill (1981); Tatsumi et al. (1983, 1986); Tatsumi (1989); Furukawa (1993); Iwamori (1998); Peacock and Wang (1999).

Aqueous fluids and silicate melts are widely regarded as the two end-member slab-derived components that drive partial melting and magma generation in volcanic arc settings. These slab components enrich the mantle wedge in large ion lithophile elements (LILE) and light rare earth elements (LREE), respectively (Gill, 1981; Ryan et al., 1995). Arc magmas are characterised by near-ubiquitous enrichments in LILE, which are highly soluble in aqueous fluid, and thus indicate prevalent enrichment of 


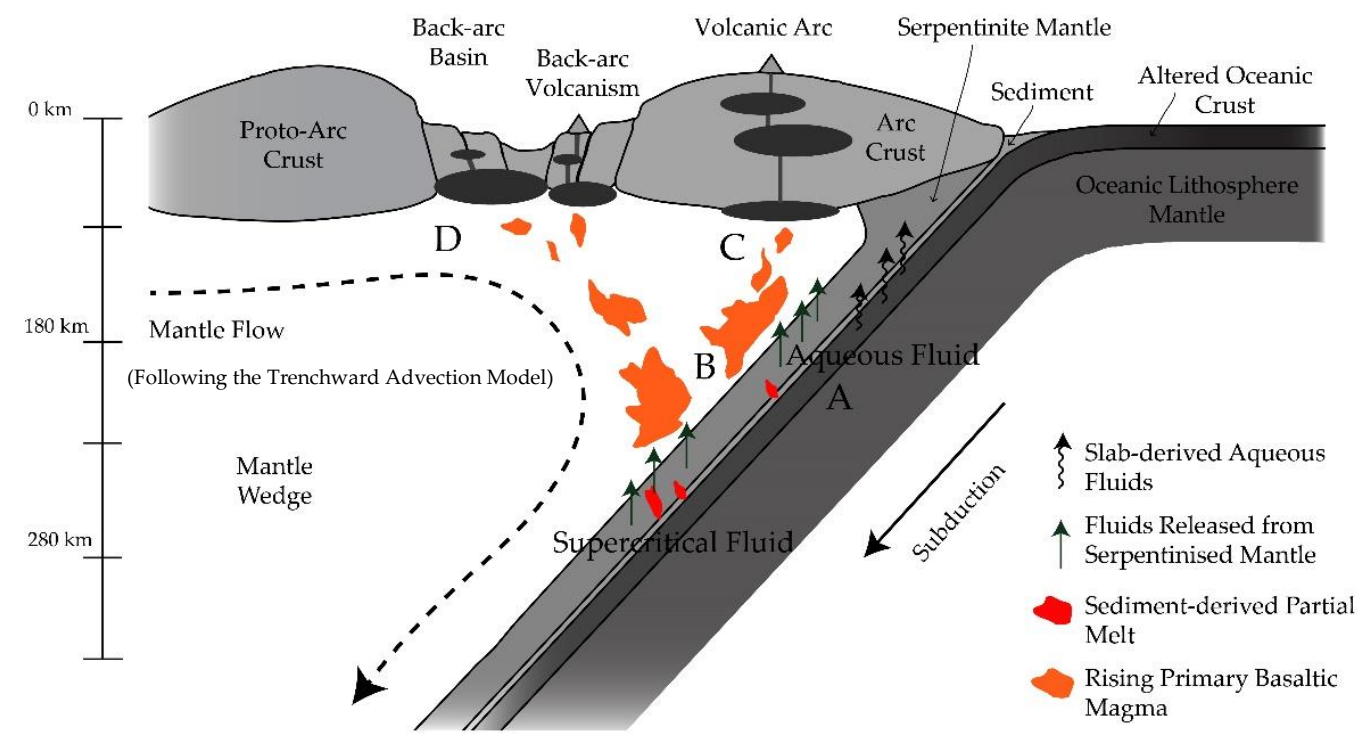

Figure 1.2 Schematic model for subduction zone magmatism in the southern KAHT.

A. Fluids and melts released from the slab get transferred into serpentinite mantle, then into the mantle wedge. B. Partial melts rise upward to the base of the overriding oceanic crust. C. Arc magmas differentiate from ascending partial melts. D. Back-arc magmas can originate from (i) slab-derived partial melts, or (ii) decompression melting of the mantle wedge, or a combination of both. Depths correspond to estimated depth of subducting slab underneath the volcanic arc-front and Havre Trough in the southern KAHT from Syracuse et al. (2010). Predicted regions of aqueous fluid transfer and supercritical fluid transfer are from Kessel et al. (2005) and Todd et al. (2011). Modified from Wysoczanski et al. (2012).

aqueous fluid in the mantle wedge, at relatively shallow depths (Brenan et al., 1995; Keppler, 1996; Brenan et al., 1998; Pearce and Stern, 2006). LREE are less soluble in aqueous fluids, and their enrichments in arc magmas are interpreted to be due to the addition of a silicate melt component into the ambient mantle wedge (Elliott et al., 1997; Hawkesworth et al., 1997; Plank and Langmuir, 1998; Johnson and Plank, 2000). Subducting sediment may be transferred into the mantle wedge as a fluid or a melt (Tatsumi, 2001; Tollstrup and Gill, 2005; Duggen et al., 2007; Portnyagin et al., 2007). High field strength elements (HFSE) are strongly compatible ${ }^{1}$ in mineral phases that are refractory at subduction settings beneath the arc front, and in comparison to other trace elements with similar partition coefficients, are generally depleted in arcfront magmas (Gill, 1981; Woodhead et al., 1993; Pearce et al., 1999).

Melting experiments undertaken by Kessel et al. (2005) have demonstrated that at higher pressure ( $\geq 6 \mathrm{GPa}$ ), aqueous fluids and silicate melts converge into a single phase that they defined as a supercritical liquid. When compared with aqueous fluids, they found that supercritical fluids are characterised by higher fluid/rock

\footnotetext{
${ }^{1}$ Elements with a solid/melt partition coefficient as $>1$
} 
distribution coefficients for both LILE and most rare earth elements (REE). Supercritical fluids have been regarded to be the predominant fluid phase that transfers LILE and REE from the subducting slab at greater depths in the back-arc region behind the arc front (e.g. $\leq 180 \mathrm{~km}$ deep), than those beneath the arc-front (Kessel et al., 2005; Klemme et al., 2005; Hermann et al., 2006).

A number of studies have indicated that enrichments in LILE in back-arc magmas may also be attributed to the release of $\mathrm{H}_{2} \mathrm{O}$-rich fluids from serpentinites at greater depths in the back-arc region behind the arc front, compared with depths beneath the arc-front (e.g. Rüpke et al., 2004; Stern et al., 2006). Silicate melts may also be transferred from the subducting slab at greater depths in the back-arc, but require temperature conditions of the mantle wedge behind the arc-front to exceed the sediment solidus, in order to trigger partial melting (Schmidt and Poli, 1998; Johnson and Plank, 2000; Tollstrup and Gill, 2005).

Temperature conditions in the mantle sufficient for partial melting are widely regarded to follow trench ward advection models (e.g. McCulloch and Gamble, 1991; Woodhead et al., 1993; Martinez and Taylor, 2006), where hotter parts of the mantle rise toward low-pressure regions beneath the back-arc and then flow towards the corner of the mantle wedge, and then sink as a result of subduction of the colder and denser oceanic plate (Figure 1.2). Recent work has demonstrated that in some arc settings, the along-strike thermal structure of the mantle wedge may be heterogeneous (e.g. Tamura et al., 2001; Honda and Saito, 2003; Honda et al., 2010). Tamura et al. (2002) modelled the thermal structure in northeast Japan, and suggested that arc volcanism was driven by anomalous thermal regions in the mantle wedge that resemble a finger-like pattern, which they termed as "hot fingers". Within the backarc, in regions where the mantle wedge is hotter, they suggest that temperature conditions are sufficient for high degrees of partial melting, which would result in constructional arc-volcanism.

Partial melts of the mantle wedge are inferred to have primitive high-Mg starting composition (Tatsumi, 1989). Owing to their high $\mathrm{H}_{2} \mathrm{O}$ contents, these primitive melts ascend up to shallower regions of the mantle wedge, and subsequently into the overlying oceanic lithosphere, where they stall and undergo differentiation via fractional crystallisation and/or assimilation (Tatsumi et al., 1983). Unlike continental 
arc settings, oceanic back-arc volcanism involves interaction between two plates that only consist of oceanic lithosphere, which is generally thinner, more refractory, compositionally similar, and does not contain isotopic and trace element enrichments associated with remnant continental lithosphere (Stern et al., 2006). Therefore, the effects of assimilation on magma petrogenesis in intra-oceanic arcs are expected to be minimal. However, care needs to be taken when addressing specific sites where backarc volcanoes are located, as many back-arc basins have complex morphologies, and may be comprised of crustal material which may modify the composition of any intruding magma. It is unlikely that a primary magma will migrate far from its source of partial melting without being modified by the assimilation of surrounding material. More evolved silicic magma has been more frequently observed in intra-oceanic arcs in recent years (e.g. Leat et al., 2003; Wright et al., 2006; Tani et al., 2008; Tamura et al., 2009), with resulting models predicting that the compositions of evolved oceanic arc magmas have undergone differentiation as a result of fractional crystallisation (e.g. Haase et al., 2006; Barker, 2010; Saunders et al., 2010; Timm et al., 2011; Barker et al., 2013) and/or anatexis via dehydration melting (e.g. Tamura and Tatsumi, 2002; Smith et al., 2003, 2006) in the sub-arc crust.

Diversity in REE patterns of basaltic back-arc magmas reflects heterogeneity in the ambient mantle wedge, which has been variably modified over time by the addition of subduction-derived components and the removal of material via episodes of melt extraction (Taylor and Martinez, 2003; Pearce et al., 2005; Martinez and Taylor, 2006). Models for mantle wedge corner-flow predict that, if the mantle underwent any melt extraction event prior to the initiation of arc volcanism, then the resulting HFSE-depleted signature would be carried to the arc-front as a result of trenchward advection, where it may undergo additional partial melting (e.g. McCulloch and Gamble, 1991; Woodhead et al., 1993). Hochstaedter et al. (2000) demonstrated that the mantle source associated with back-arc volcanism is less depleted than the mantle at the arc-front in the Izu-Bonin arc. Interactions between recently added subduction components and pre-existing heterogeneous components in the ambient mantle are well-documented in back-arc magmas, where isotopically enriched mantle components have not been removed during partial melting, and variable subduction components can be added at variable depths and temperatures (Todd et al., 2010, 2011). Obtaining absolute ages from back-arc volcanoes allows for 
more specific and precise constraints to be placed on magmatic events associated with back-arc volcanism, and also provides an opportunity to improve proposed models for the timing and magmatic evolution of intra-oceanic arc-back-arc systems.

\subsection{Back-Arc Volcanism in the Southern Kermadec Arc- Havre Trough}

The Kermadec Arc-Havre Trough (KAHT) is a relatively young oceanic arcback-arc system that became active in the Quaternary (Mortimer et al., 2010). Early studies carried out in the southwest Pacific Ocean in the 1960s recognised that the Tonga-Kermadec Arc was an example of an intra-oceanic volcanic system associated with arc magmatism, and the Lau Basin-Havre Trough as a site of back-arc crustal extension (e.g. Brothers, 1967; Karig, 1970). As one of the youngest global examples of an active arc-back-arc system, the Tonga-Kermadec Lau-Havre arc-back-arc has been a key location for investigating and modelling magmatic and tectonic processes that occur at subduction zone settings (For a full review see Smith and Price (2006)). Since the initial studies were carried out, a number of research voyages have been undertaken in the KAHT to investigate the key petrologic, tectonic and geophysical characteristics of the arc-back-arc system (Table 1.1). It was not until the advent of more sophisticated data acquisition equipment, in particular high-resolution multibeam bathymetric swath mapping (with a resolution of $30 \mathrm{kHz}$ ), that submarine portions of the arc-back-arc system were surveyed and mapped in any detail (Figure 1.3). This has led to the discovery of submarine constructional volcanic edifices along the southern Kermadec Arc-front and in the Havre Trough Back-arc.

Evidence for back-arc volcanism in the KAHT is manifest in ridges and seamounts located in the southern Havre Trough, at $\sim 36^{\circ} \mathrm{S}$ (Rumble V Ridge), and at $\sim 34.5^{\circ} \mathrm{S}$ (Gill Seamount, Rapuhia Seamount, Rapuhia Ridge, Yokosuka Seamount and Giljanes Seamount) (Figure 1.1). These volcanic constructs have been mapped using multi-beam bathymetry and extend across the complete, or near-complete width of the Havre Trough, are bounded by back-arc rifts at both the northern and southern ends, and characterised by high backscatter reflectivity (Wysoczanski et al., 2010). Todd et al. (2010, 2011) analysed lavas erupted from Gill Seamount and the Rumble V Ridge, 


\begin{tabular}{llll} 
Voyage & Year & Voyage Leader & Vessel \\
\hline SO 135 & 1998 & P Stoffers & R/V Sonne \\
TAN0205 & 2002 & I Wright & R/V Tangaroa \\
YK06-14 & 2006 & R Wysoczanski & R/V Yokosuka \\
SO 192 & 2007 & E Flueh & R/V Sonne \\
TAN1007 & G Lamarche & R/V Tangaroa \\
TAN1213 & 2010 & R Wysoczanski & R/V Tangaroa \\
TAN1313 & 2012 & C de Ronde & R/V Tangaroa \\
TAN1512 & 2013 & C de Ronde & R/V Tangaroa \\
TAN1513 & 2015 & R Wysoczanski & R/V Tangaroa
\end{tabular}

Table 1.1. Recent marine research voyages that have been undertaken in the KAHT, where sampling and multibeam mapping has been associated with back-arc volcanism in the southern KAHT.

and found that they sample the Havre Trough mantle wedge and that their compositions are primarily attributed to slab- derived components (i.e. LILE enrichment and HFSE depletion with respect to REE concentrations) (Figures 1.3). Addition of LILE-enriched slab components triggering partial melting in the back-arc is consistent with earlier suggestions that these cross-chains are characteristic of an 'arc regime', but where the compositions reflect a subduction component that decreases with increasing depth of the subducting slab (Wysoczanski et al., 2010).

Todd et al. (2010) found that the compositions of Rumble V Ridge magmas can be explained by a slab component with a sediment melt that includes refractory accessory zircon, monazite and rutile. Compositional trends can be best explained by an increase in the mass fraction of sediment melt added from the slab with increasing distance from the arc-front. However, Todd et al. (2011) explain the compositions of lavas from adjacent back-arc rifts as being due to enrichment of the mantle wedge from a supercritical fluid (Todd et al., 2011), and suggest that the pattern of adjacent rift and arc magmatism reflects local thermal anomalies (i.e. "hot fingers" Tamura et al., 2002) present in the southern Havre Trough mantle. These thermal anomalies can account for the high temperature required for the generation of sediment melt beneath the Rumble V Ridge. Recent ${ }^{40} \mathrm{Ar} /{ }^{39} \mathrm{Ar}$ isotope analyses obtained from the cross-chain have confirmed that it is $<2 \mathrm{Ma}$, suggesting it is coeval with magmatism associated with the present-day Kermadec Arc (Gamble et al., 2009; Todd et al., 2010). 
a)

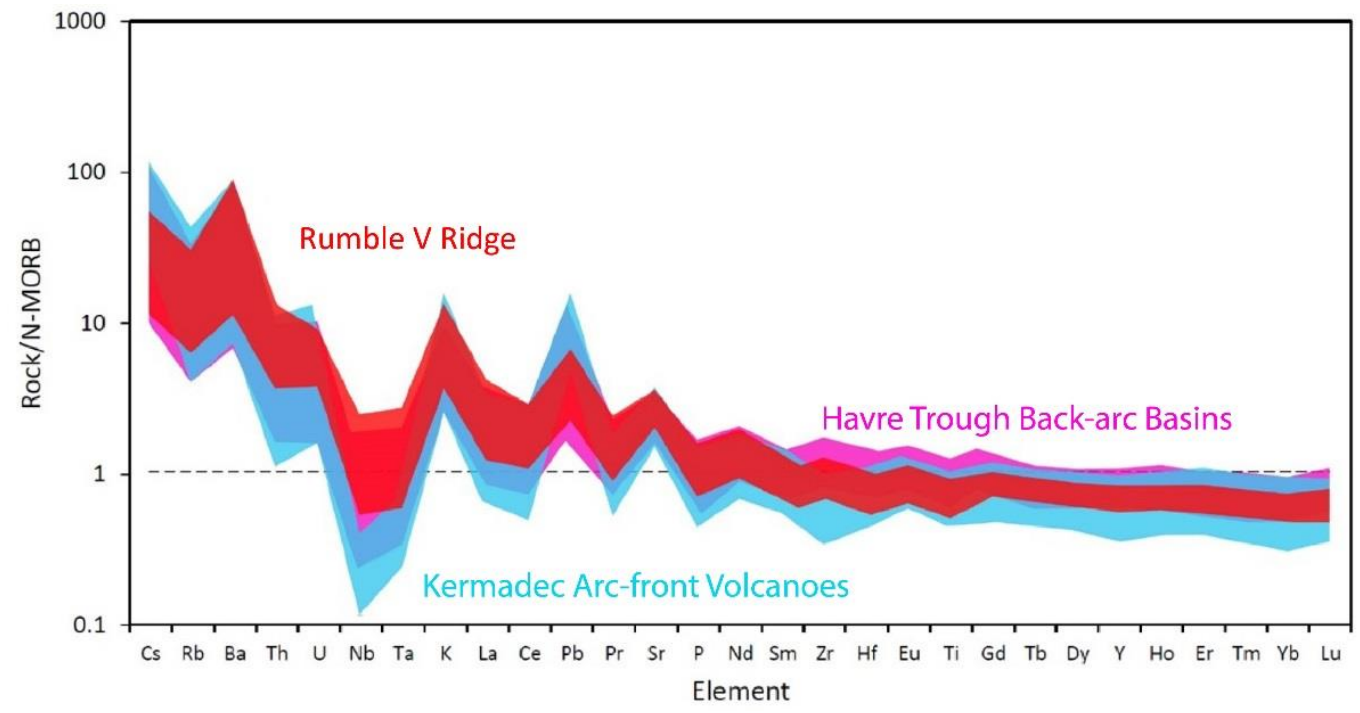

b)

c)
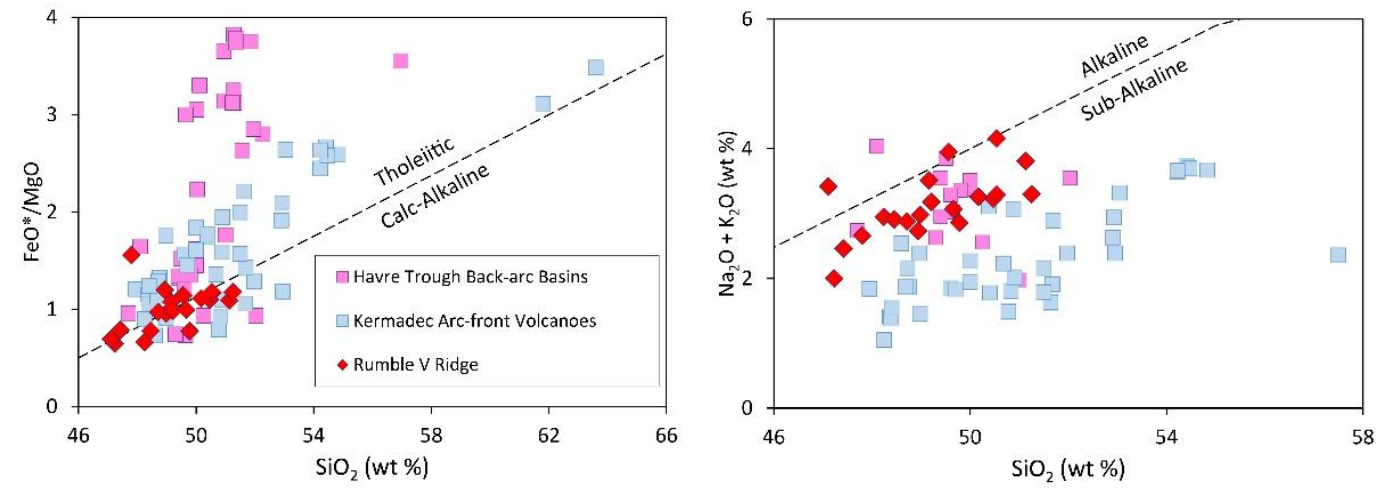

Figure 1.3. Plots showing analyses of samples from Kermadec Arc-front volcanoes, Havre Trough back-arc basins, and the Rumble V Ridge.

a) N-MORB normalised multi-element plot for representative analyses of samples in southern KAHT, from both the arc-front and back-arc. b) $\mathrm{FeO}^{* 2} / \mathrm{MgO}$ versus $\mathrm{SiO}_{2}$ (wt \%). Dashed line represents the tholeiitic-calcalkaline boundary from Miyashiro (1974). c) Total alkali contents $\left(\mathrm{Na}_{2} \mathrm{O}+\mathrm{K}_{2} \mathrm{O}\right.$ (wt \%)) versus $\mathrm{SiO}_{2}$ (wt \%). Dashed line represents alkaline-sub-alkaline boundary from Miyashiro (1978). Normalising values for NMORB in plot a) are from Sun and McDonough (1989). Symbols in plot c) are the same as in plot b). Plots modified from Todd et al. (2011). Published data obtained from Gamble (1993a, 1994); Haase et al. (2002); Wysoczanski et al. (2006, 2012); Todd et al. (2010, 2011); Timm et al. (2016).

In the southern Havre Trough, models proposed to explain coeval magmatism during back-arc extension have predicted the loci of intrusive magmatism to be along faulted regions of pre-existing extended basement crust (e.g. Wright, 1993; Parson and

${ }^{2}$ For the purposes of this study, $\mathrm{FeO} *$ is calculated as $\mathrm{FeO}+0.9 * \mathrm{Fe}_{2} \mathrm{O}_{3}$ from Miyahisro (1978). 
Wright, 1996; Martinez and Taylor, 2006; Wysoczanski et al., 2010). Gill Seamount, however, is situated in the middle of a deep basin 3000 mbsl (Wysoczanski et al., 2010). Located to the east of Gill Seamount, Rapuhia Seamount, Rapuhia Ridge, Yokosuka Seamount and Giljanes Seamount are all situated on an elevated basal plateau, 2500 mbsl (Wright et al., 2006; Wysoczanski and Clark, 2012). The composition of the plateau is unknown, but has been suggested by Wright et al. (2006) to comprise arc basement crust associated with Colville Arc magmatism. With the exception of a few analyses, the compositions of these stratovolcanoes remain largely unknown. Recently proposed models (e.g. Todd et al., 2010, 2011; Wysoczanski et al., 2010) that account for the melt productivity required for the construction of edifices in the southern Havre Trough are limited by a lack of detailed analyses of samples from these stratovolcanoes. A primary aim of this thesis is to analyse samples from these stratovolcanoes in detail to provide data that will allow for the creation of more refined models regarding magma generation in the southern Havre Trough.

These previous studies from the Rumble V Ridge and the Havre Trough ambient mantle wedge provide an excellent framework from which to investigate magmatism associated with the $\sim 34.5^{\circ} \mathrm{S}$ cross-chain that includes the back-arc volcanoes Gill Seamount, Rapuhia Seamount, Rapuhia Ridge, Yokosuka Seamount and Giljanes Seamount. Samples of lavas erupted from these stratovolcanoes have been collected during marine research voyages R/V Tangaroa TAN0205 and R/V Yokosuka YK06-14, and form the basis of this study. This work, which builds on the geochemical studies undertaken by Todd et al. $(2010,2011)$ of analyses of lavas from both cross-chains, will investigate previous suggestions regarding how back-arc volcanism occurs in the southern Havre Trough.

\subsection{Thesis Objectives and Outline}

The primary aim of this thesis is to constrain the origin and evolution of backarc volcanism in the southern KAHT. This study involves carrying out the first detailed petrological and geochemical study on lavas erupted from four back-arc stratovolcanoes of the southern Havre Trough: Gill Seamount, Rapuhia Seamount, Rapuhia Ridge, Yokosuka Seamount, and Giljanes Seamount. 
This study combines whole rock major element and trace element data, as well as in situ analyses of mineral phenocrysts and ${ }^{40} \mathrm{Ar} /{ }^{39} \mathrm{Ar}$ isotope analyses, of selected samples from the back-arc stratovolcanoes located within the southern Havre Trough. The geochemical dataset provides new insights into magmatic processes that have been occurring during the evolution of the arc-back-arc system, since Colville Arc magmatism during the Miocene, and processes that may be associated with the construction of arc-like stratovolcanoes in the middle of deep rifts and on extended crustal plateaux, within an extensional back-arc setting.

This research will address the following questions:

1. What is the extent of the transfer of aqueous fluid and sediment melt components from the subducting slab into the Havre Trough back-arc mantle wedge, and how does it compare with subduction-derived processes associated with volcanism at the Kermadec arc-front?

2. Why is there arc volcanism in deep back-arc rifts and on crustal plateaux in the southern Havre Trough, and how do their respective magmatic processes compare to those driving volcanism at the Kermadec arc volcanic-front?

3. What is the composition of the ambient mantle wedge from which the back arc volcano melts are derived, and is there evidence for heterogeneity in the backarc mantle?

4. Can the location of these back-arc stratovolcanoes and cross-arc chains be linked to source variations?

These questions will constrain how the arc mantle and arc-back-arc system have evolved through time, from Colville Arc magmatism at at least $17 \mathrm{Ma}$, to the present day Kermadec Arc (Mortimer et al., 2010).

The main analytical techniques that have been used in this study include:

- Bulk rock petrography on selected thin sections

- Major element geochemical analysis on whole rock samples using X-Ray fluorescence (XRF) spectrometry 
- Trace element geochemical analysis on whole rock samples using solution sector field inductively coupled plasma mass spectrometry (SF ICP-MS)

- Mineral in situ major element geochemical analysis using electron probe micro analysis (EPMA)

- Argon-argon $\left(\mathrm{Ar}^{40} / \mathrm{Ar}^{39}\right)$ isotope geochronology on mineral separates

This thesis is presented in six chapters.

Chapter 1) Introduction: An overview of back-arc volcanoes and their occurrence in the southern Kermadec Arc-Havre Trough. The main research objectives of this thesis are also briefly discussed.

Chapter 2) Geological Setting: A general overview of the southern Kermadec ArcHavre Trough, a background to the magmatic evolution of the Kermadec Arc-Havre Trough, and the main volcanoes which are investigated in this thesis.

Chapter 3) Methods: A description of the methods used to obtain the petrographic, geochemical and geochronological data in this thesis. The analytical standards used to obtain the precision and accuracy of each analytical technique are also described.

Chapter 4) Results: The key results obtained in this study are presented. This section is sub-divided into petrographic, geochemical, mineralogical and geochronological results.

Chapter 5) Discussion: An interpretation of the results, focussing on the key magmatic processes associated with each of the back-arc stratovolcanoes and the mantle source. Comparisons are made to magmatic processes occurring at arc-front volcanoes and other back-arc volcanoes, within the Kermadec Arc and at other intraoceanic arcs.

Chapter 6) Conclusions: A summary of the key findings of this study and recommendations for future work.

References: A complete list of all the references cited in this thesis. 
Appendices: A series of appendices (A1-A4) are attached, that contain sample information, representative petrographic data, and analytical standards used during this study. Additional electronic appendices (EA.1-EA.4) are available that contain all the whole rock and mineral chemical data collected during this study. 


\section{Chapter 2: \\ Geological Setting and \\ Sample Locations}




\subsection{The Kermadec Arc-Havre Trough Subduction System: An Overview}

Associated with Australian-Pacific plate convergence along the TongaKermadec Trench, the Kermadec Arc-Havre Trough (KAHT), coupled with the Tonga Arc-Lau Basin farther north, make up an intra-oceanic island arc-back-arc system that extends for $\sim 2600 \mathrm{~km}$ in the southwest Pacific, to the northeast of New Zealand (Ewart et al., 1977; Regelous et al., 1997; Timm et al., 2013) (Figure 2.1). The TongaKermadec Arc is associated with one of the world's deepest trenches, most volcanically active arc systems, and some of the coldest slab surface temperatures predicted on Earth (Syracuse et al., 2010; Timm et al., 2013; Timm et al., 2014). Relative rates of convergence decrease southward with increasing distance from the Pacific-Australian pole of rotation, from $\sim 24 \mathrm{~cm} / \mathrm{yr}$ at the northern Tonga Arc, to $\sim 5$ $\mathrm{cm} / \mathrm{yr}$ at the southern Kermadec Arc (DeMets et al., 1994) (Figure 2.1). Westward subduction of the Pacific Plate at the Tonga-Kermadec Trench is accompanied by rollback of the subducted slab and back-arc extension in the Lau Basin and Havre Trough (Parson et al., 1994; Gamble and Wright, 1995; Gamble et al., 1996). Rates of extension increase northwards from $15 \mathrm{~mm} / \mathrm{yr}$ at the southern Havre Trough to 85 $\mathrm{mm} / \mathrm{yr}$ at the Lau Basin (DeMets et al., 1994). The boundary between the Kermadec Arc-Havre Trough and the Tonga Arc-Lau Basin is delineated by the intersection between the remnant Louisville Seamount Chain (LSC) and the Tonga-Kermadec trench, where extension in the northern Havre Trough is inferred to be locked as a result of LSC subduction (Ruellan et al., 2003).

The KAHT comprises the southern section of the arc-back-system, and extends for $\sim 1300 \mathrm{~km}$ until it reaches continental New Zealand, where there is a transition from oceanic to continental arc volcanism associated with the Taupo Volcanic Zone (TVZ) (Gamble et al., 1990; Gamble et al., 1993a, 1993b; Wilson et al., 1995) (Figure 2.1). The Ngatoro Rift comprises the southern-most tip of the Havre Trough, where rifting is inferred to have penetrated into the New Zealand continental margin (Gamble et al., 1993b; Gamble and Wright, 1995). A number of studies have shown that the KAHT displays considerable variation in terms of magmatic composition, crustal structure and morphology along its length. North of $32^{\circ} \mathrm{S}$, the Kermadec arc-front volcanoes surmount the Kermadec Ridge, although they are located immediately to 


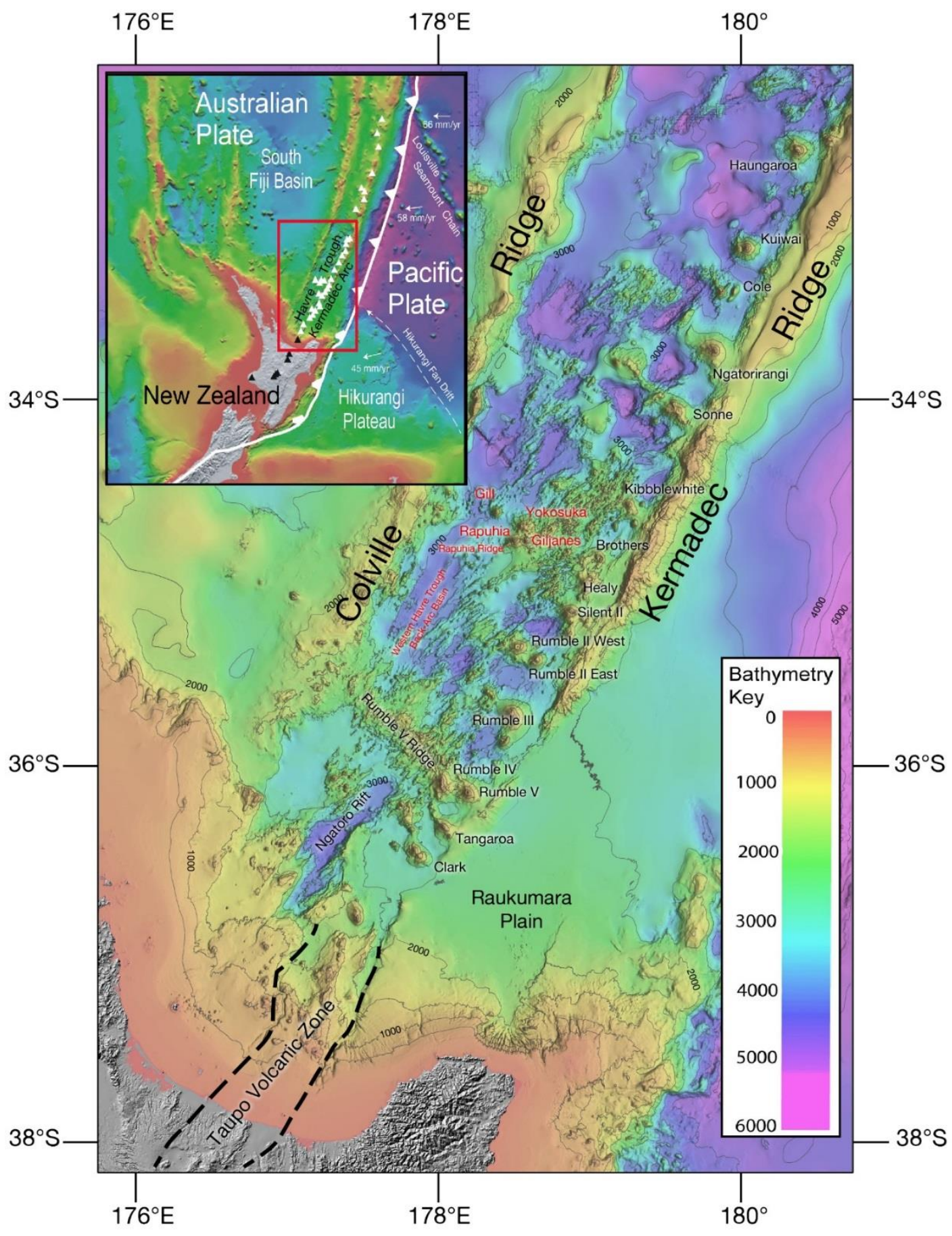

Figure 2.1 Regional setting of the southern Kermadec Arc-Havre Trough.

The red rectangle in the inset map shows the location of KAHT in relation to the Tonga-Kermadec subduction system. Relative Pacific-Australian plate motions ( $\mathrm{mm} / \mathrm{yr}$ ) in the inset map are represented by arrows, and are from Wallace et al. (2009), after DeMets et al. (1994). The modern outline of the TVZ is taken from Wilson et al. (1995). The direction of sediment drift ('Hikurangi Fan Drift') is from Carter et al. (1996). The volcanoes and basins investigated in this study are shown in red text. Modified from Wysoczanski et al. (2010). 
the west north of $28.5^{\circ} \mathrm{S}$ (Timm et al., 2014). At $\sim 32^{\circ} \mathrm{S}$ and farther south, the arc-front volcanoes are located $\sim 15 \mathrm{~km}$ to the west of the Kermadec Ridge, and both the Colville and Kermadec ridges narrow in width by nearly half (Wright, 1997) (Figure 2.1). The Havre Trough to the north of $32^{\circ} \mathrm{S}$ is comprised of a simple horst and sediment-filled graben, and is relatively shallow (2000-2500 mbsl) compared with the Havre Trough south of $32^{\circ} \mathrm{S}$, which is deeper (3000-4000 mbsl) and comprised of complex rifts and horst and half-grabens, and is generally sediment-poor (Caress, 1991; Wright, 1997; Ballance et al., 1999). Previous work has shown that these variations coincide with changes associated with the tectonic parameters along the Kermadec trench, such as increased sedimentation associated with the Hikurangi fan drift (e.g. Carter et al., 1996), as well as subduction of the Hikurangi Plateau, which is associated with increased tectonic erosion in the fore-arc region (Davy and Collot, 2000; Timm et al., 2014) (Figure 2.1).

With the exception of a few subaerial volcanic islands (e.g. Raoul Island and Herald Islets, Macauley Island, Curtis Island and L'Esperance Rock), volcanoes of the Kermadec Arc are submarine, and have been largely undocumented in comparison with other oceanic arcs (Smith and Price, 2006). Research voyages have surveyed and sampled along the arc-front. Multi-beam mapping has revealed that south of $30^{\circ} \mathrm{S}$, the Kermadec Arc consists of at least 35 edifices that are stratovolcanoes and/or silicic calderas, but also may include edifices with multiple vents, where both calderas and composite cones are present (Wright et al., 2006; Wysoczanski et al., 2010). Edifice growth in the southern KAHT has been suggested to be controlled by back-arc extension (e.g. Wright et al., 2006; Campbell et al., 2007), which trends obliquely into the arc-front (Delteil et al., 2002), and is manifest in faults, ridges and dikes, as well as aligned vents and cones. These studies have led workers to suggest that the magmatic evolution of each stratovolcano is modified by repeated cycles of construction and sector collapse (e.g. Wright et al., 2006). Wright et al. (2006) observed both dacitic and basaltic-andesitic lavas from stratovolcanoes associated with shallower crustal depths, with dacite displaying more compositional diversity, whereas only basaltic-andesitic lavas observed from stratovolcanoes located on thinner crust. They suggested that dacitic magma genesis is strongly influenced by crustal thickness, where the generation of basaltic magma results in thermal conditioning of the thicker sub-arc crust and where magmas can stall and undergo 
differentiation at temperatures sufficient for anatexis. A number of recent studies (e.g. Haase et al., 2006; Barker, 2010, 2013; Saunders et al., 2010; Timm et al., 2011; Herbert, 2013) have revealed that silicic magma generation in the Kermadec Arc can be explained by fractional crystallisation.

\subsection{Background to Magmatism at the Kermadec Convergent Margin}

A number of volcanic arcs and back-arc basins have formed in the southwest Pacific region during the Cenozoic, with subsequent cessation in arc volcanism (e.g. Parson et al., 1990; Schellart et al., 2006; Mortimer et al., 2007, 2010). Prior to the formation of the Tonga-Kermadec Arc, the most recent period of arc magmatism in the southwest Pacific occurred on the present-day Lau-Colville Ridge, located to the west of the present-day KAHT (Herzer, 1995; Ballance et al., 1999) (Figures 1.1, 2.1). The Colville Ridge comprises the southern portion of the ridge, and is an expression of the now-remnant Colville Arc, which was active from at least $17 \mathrm{Ma}$ (Ballance et al., 1999; Mortimer et al., 2010). As a result of back-arc extension in the Havre Trough, the Colville Arc is now separated into two parallel ridges: the Colville Ridge and the Kermadec Ridge. The Colville and Kermadec ridges define the western and eastern margins of the KAHT, respectively (Wright, 1997). Volcanoes of the Kermadec Arc are located within 20-30 km of the Kermadec Ridge (Graham et al., 2008; Timm et al., 2014).

\subsubsection{Colville Arc Magmatism}

There has been limited sampling and mapping undertaken in the Colville Arc, and as a result, the composition, age and geomorphology of Colville Arc features remain largely unknown. Recent multi-beam mapping and dredge sampling during the $R / V$ Tangaroa voyages TAN1007 and TAN1213 included targeting regions of the remnant Colville Arc (Handler et al., 2011). Samples collected during these voyages consist of plagioclase-rich and olivine-rich basaltic-andesites (Handler et al., 2011). 
Colville Ridge samples collected during the $R / V$ Tangaroa TAN1007 voyage have been analysed by Handler et al. (2011), who found that compositions of glasses and olivine-hosted melt inclusions are characterised by a tholeiitic trend similar to the modern Kermadec Arc volcanic-front (Figure 2.2). When compared to prior analyses of present-day Kermadec Arc lavas, whole rock analyses of Colville Arc lavas were characterised by lower concentrations of $\mathrm{SiO}_{2}$ and higher concentrations of $\mathrm{Al}_{2} \mathrm{O}_{3}$ and $\mathrm{K}_{2} \mathrm{O}$ (Handler et al., 2011). They inferred the whole rock Colville Arc analyses to reflect crystal accumulation of plagioclase ( \pm olivine) during Colville Arc magmatism.

In situ analyses of individual mineral phases show significant differences between minerals from Colville Arc and Kermadec Arc lavas (Figure 2.2). For example, the Or contents in plagioclase phenocrysts from the Colville Arc are higher than those observed in typical low-K tholeiitic Kermadec Arc lavas (Figure 2.2), but lower than observed levels in the high-K Kermadec Arc suite. Olivine phenocrysts from the Colville Arc suite are characterised by higher levels of $\mathrm{Ni}$ (up to $0.5 \mathrm{wt} \%$ ) and Fo (90-94 mol. \%), when compared with lavas from the Kermadec Arc, and spinel inclusions that are characterised by higher levels of $\mathrm{Cr}(\mathrm{Cr} \# \sim 0.8)$, and lower $\mathrm{TiO}_{2}$ $(<0.4 \mathrm{wt} \%)$, compared with samples from the southern Kermadec Arc. These findings led Handler et al. (2011) to suggest that magma plumbing processes associated with the Colville Arc magmatic system were different and more alkali-rich than magma plumbing associated with the present-day Kermadec Arc magmatism.

Trace element analyses of the Colville Arc suite show a subduction component, with enrichments in LILE, and depletions in HFSE. All samples contain an aqueous fluid component that is lower than that observed in present-day Kermadec Arc samples, but a similar sediment melt component (Figure 2.3). Isotopic analyses of $\mathrm{Pb}$ for Colville Arc samples plot within field defined by previous analyses of Kermadec Arc magmas, leading Handler et al. (2011) to suggest that subduction slabderived components associated with Colville Arc magmatism were similar to those currently associated with the Kermadec Arc. 
a)

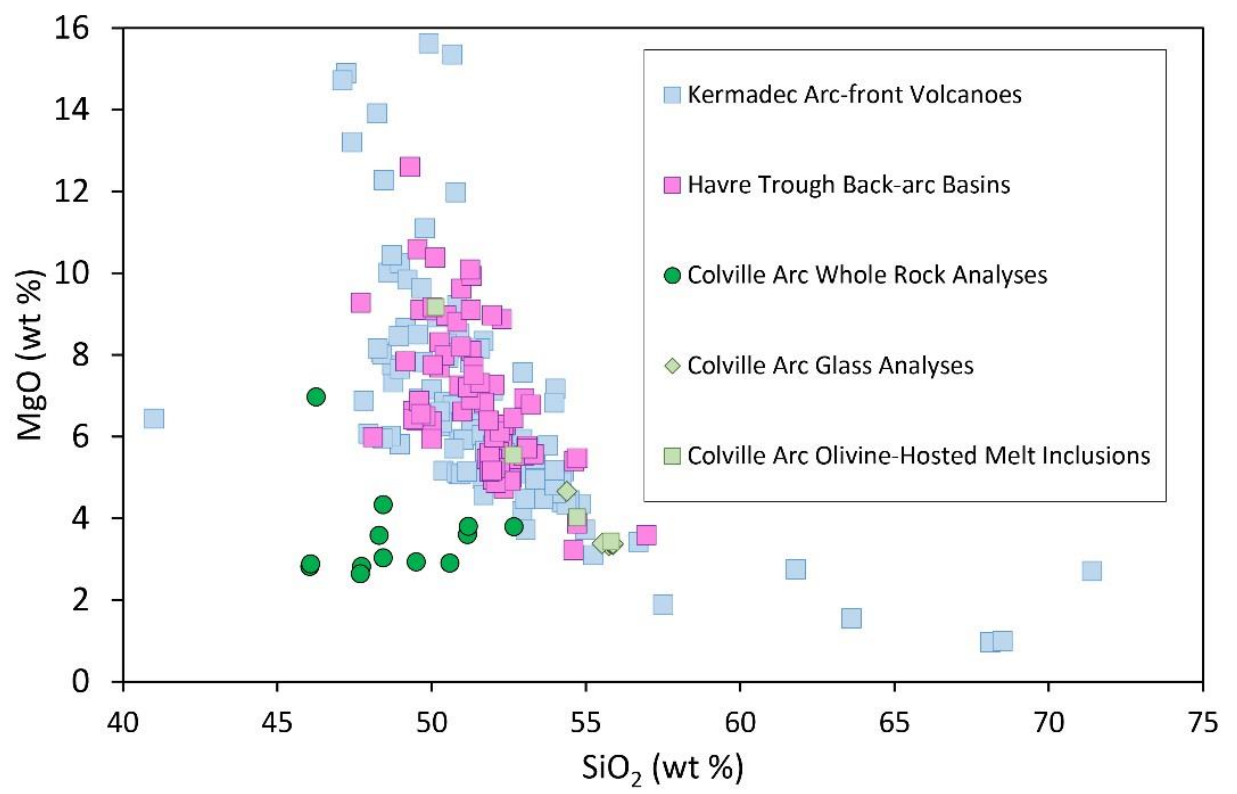

b)

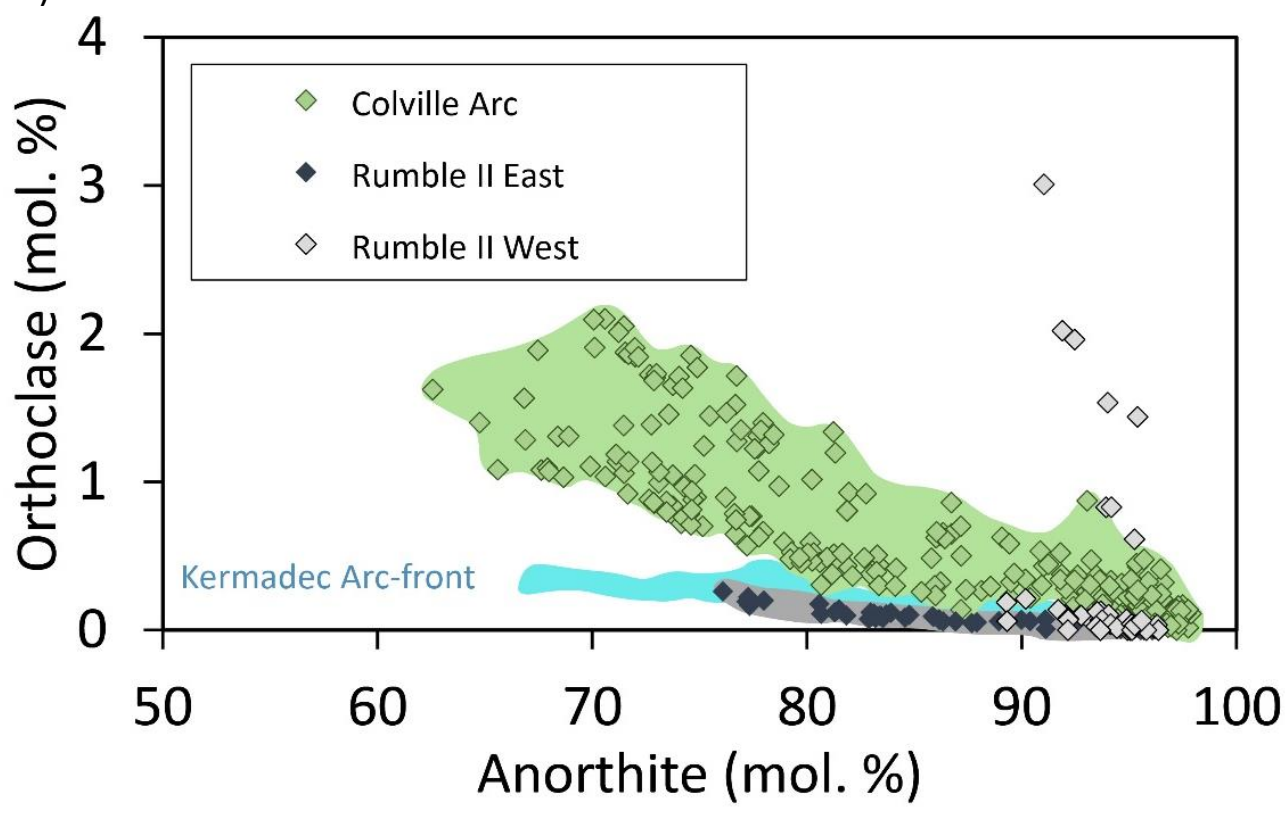

Figure 2.2. Plots showing the relationship of whole rock and plagioclase compositions of samples from the Colville Arc, Kermadec Arc-front, and Havre Trough Back-Arc Basins.

a) Plot of $\mathrm{MgO}$ (wt \%) vs $\mathrm{SiO}_{2}$ (wt \%) for whole rock analyses, and b) orthoclase (Or) versus anorthite (An) content of plagioclase crystals. In both plots, samples are from Colville Ridge, Kermadec Ridge, and KAHT. Data obtained from Gamble et al. (1990, 1993a, 1993b, 1994, 1996, 1997); Haase et al. (2002); Wysoczanski et al. (2006, 2012); Handler et al. (2011); Timm et al. (2016). The green, grey and blue fields show the ranges of plagioclase compositions from the Colville Arc, Rumble II East, and Kermadec Arc-front, respectively. Colville Arc whole rock data, glass analyses, and olivine-hosted melt inclusions are unpublished data from Handler pers. comms. (2016). Colville Arc and Kermadec Arc-front plagioclase data are unpublished data from Wysoczanski pers. comms. (2016). Rumble II West and East plagioclase data come from Timm et al. (2016). 
Element ratios that model melt depletion suggest Colville Arc samples have compositions that indicate the Miocene mantle wedge was less depleted than that of the present-day KAHT, but was comparable to that of the Havre Trough ambient mantle wedge (Figure 2.3). These differences in source depletion could be attributed to increasing depletion in the mantle wedge over time, or due to the absence of melt extraction during back-arc magmatism behind the Colville Arc during the Miocene (Handler et al., 2011).

a)

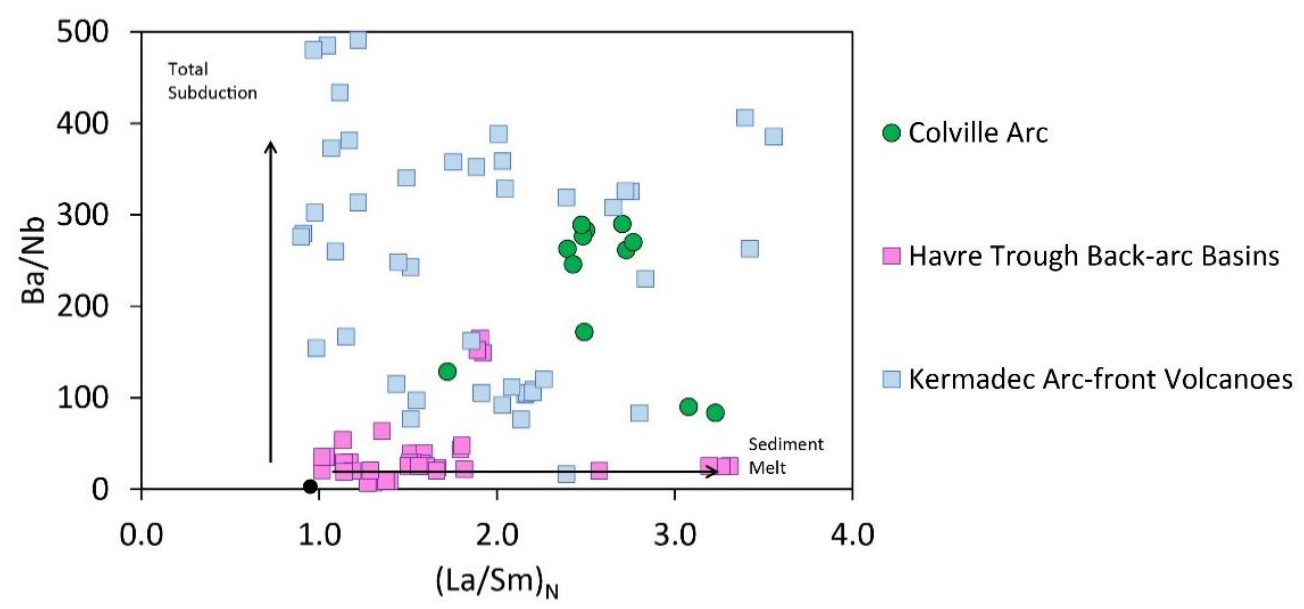

b)

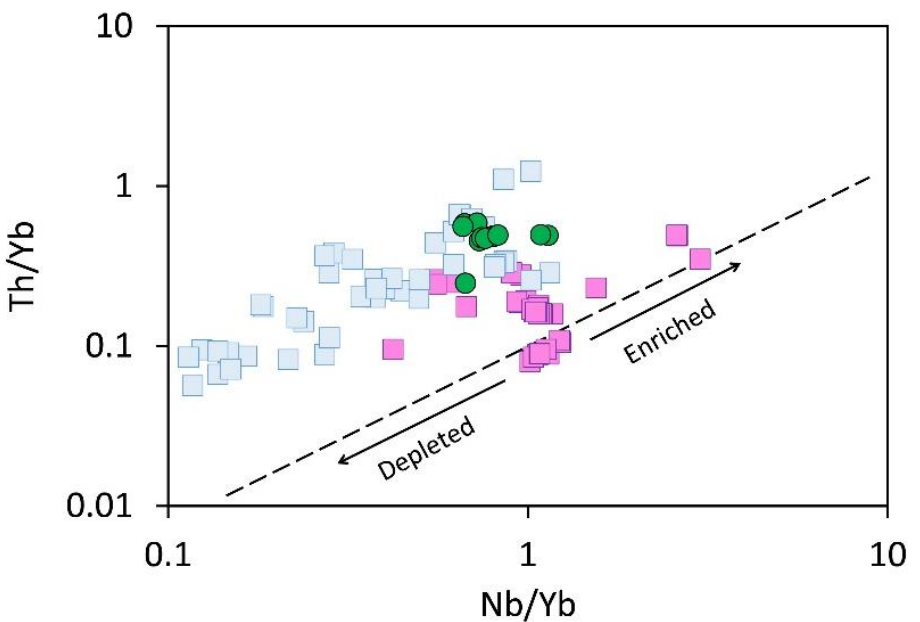

Figure 2.3. Plots showing the relationships between total subduction components and source depletion for lavas from the Colville Arc, Kermadec Arc-front volcanoes, and Havre Trough Back-arc basins.

a) Plot of $\mathrm{Ba} / \mathrm{Nb}$ versus $(\mathrm{La} / \mathrm{Sm})_{\mathrm{N}}$ ( $\mathrm{N}$ denoting normalised to $\left.\mathrm{N}-\mathrm{MORB}\right)$. Black circle represents $\mathrm{Ba} / \mathrm{Nb}$ and $\mathrm{La} / \mathrm{Sm}$ values for N-MORB. Values for N-MORB are from (Sun and McDonough, 1989). Black arrows represent the extent at which the compositions of lavas are modified by the total subduction and sediment melt slab-derived components. b) Plot $\mathrm{Th} / \mathrm{Yb}$ versus $\mathrm{Nb} / \mathrm{Yb}$, where the mantle is regarded as being enriched when $\mathrm{Nb} / \mathrm{Yb}>1$, and depleted when $\mathrm{Nb} / \mathrm{Yb}<1$. Dashed line represents the MORB mantle array from Pearce (2008). Symbols are the same in both plots. Data obtained from Gamble et al., (1990, 1993a, 1993b, 1994, 1996, 1997); Haase et al., (2002); Wysoczanski et al., (2006, 2012); Handler et al., (2011); Timm et al., (2016). 
Owing to limited sampling and a lack of geochronological data, the inferred ages for cessation of Colville Arc magmatism and initiation of back-arc extension in the Havre Trough are poorly constrained. A K/Ar age of 5.4 \pm 0.1 Ma for a Colville Arc sample suggested that the Colville Arc was a single active ridge and that back-arc extension in the Havre Trough had not yet commenced at that time (Adams et al., 1994). Mortimer et al. (2010) obtained an age of 16.7 Ma, leading them to suggest that the Colville Arc was active during the Miocene. Using integrated rates of extension and ages from onshore volcanic records, Wright (1993) estimated an age of $5 \mathrm{Ma}$ for opening of the southern Havre Trough. However, recent work has indicated that magmatism has occurred more recently within the Havre Trough. ${ }^{40} \mathrm{Ar} /{ }^{39} \mathrm{Ar}$ age of $1.12 \pm 0.38 \mathrm{Ma}$ was obtained for a basalt from the Havre Trough (Mortimer et al., 2007). Intrusive lava flows on the floors of back-arc basins, and volcanism at arcnormal seamounts and ridges, have all been inferred to be associated with recent magmatism (e.g. Wysoczanski et al., 2010).

\subsubsection{Southern Kermadec Arc Magmatism}

In contrast to the Colville Arc, the petrology and petrogenesis of Kermadec Arc magmas have been extensively studied (Ewart et al., 1977, 1998; Gamble et al., 1990, 1993a, 1993b, 1996, 1997; Haase et al., 2002; Wright et al., 2006; Wysoczanski et al., 2006; Barker et al., 2013; Timm et al., 2014, 2016), and they display more chemical diversity than magmatism in the Tonga Arc (Ewart et al., 1977; Smith and Price, 2006). Volcanism is predominantly basaltic-andesitic in composition (Gamble et al., 1990, 1993a, 1993b, 1997), but recent work has shown that silicic magmatism is also a major component (e.g. Smith et al., 2003, 2006; Haase et al., 2006; Barker et al., 2013), particularly along segments of the arc-front with calderas on thicker subarc crust (Wright et al., 2006). In general, basaltic-andesitic magmas in the southern Kermadec Arc are porphyritic and vesicular, K-poor $\left(\sim 0.3\right.$ wt $\% \mathrm{~K}_{2} \mathrm{O}$ at 52.6 wt $\%$ $\mathrm{SiO}_{2}$ ), and follow tholeiitic evolution trends with fractional crystallisation of olivine + orthopyroxene + clinopyroxene + plagioclase in the parental magmas (Gamble et al., 1990, 1993a, 1993b). However, a coeval suite of medium-K to high-K lavas has been erupted at Clark volcano (1.5-2.25 wt \% $\mathrm{K}_{2} \mathrm{O}$ at 52.6 wt \% $\mathrm{SiO}_{2}$ ) (e.g. Gamble et al., 1997). Major element compositions of southern Kermadec Arc magmas are regarded 
to be driven by fractional crystallisation (Gamble et al., 1990, 1993a), as well as accumulation of olivine and clinopyroxene (Timm et al., 2016). Fractionation trends have also been observed in compositions within the pillow glasses, as well as inclusions of melt hosted within phenocrysts (Wysoczanski et al., 2006, 2012).

In situ chemical analyses of olivine phenocrysts from southern Kermadec Arc samples range from Fo-91 to Fo-51 (Gamble et al., 1990; Gamble et al., 1993b; Timm et al., 2016). $\mathrm{Ni}$ and $\mathrm{MgO}$ contents range from $\sim 0.2-0.3 \mathrm{wt} \%$ and $\sim 46-50$ wt $\%$, respectively (Gamble et al., 1993b). Phenocrysts display weak zoning and have been inferred to be in equilibrium with the host melt (Gamble et al., 1990), although there is evidence for accumulation of olivine in Rumble II East lavas (Timm et al., 2016). Inclusions of $\mathrm{Cr}$-spinel hosted within olivine phenocrysts typically have $\mathrm{Cr} \# \sim 0.5-0.6$, and $\mathrm{TiO}_{2}$ contents of $\sim 0.45-0.5 \mathrm{wt} \%$ (Gamble et al., 1993b). Pyroxene phenocrysts appear weakly zoned, and are characterised by compositions with Mg\# 67-92 and $\mathrm{Cr}_{2} \mathrm{O}_{3}$ ca. 1 wt \% (Gamble et al., 1993b; Timm et al., 2016). Both orthopyroxene and clinopyroxene phenocrysts have been observed within southern Kermadec Arc samples (e.g. Gamble et al., 1990; Timm et al., 2016), with enstatite, augite and diopside occurring as the main end-member components. Plagioclase phenocrysts from southern Kermadec Arc basaltic-andesitic magmas display both normal and reverse zoning, are characterised by low levels of $\mathrm{K}_{2} \mathrm{O}(<0.25 \mathrm{wt} \%)$, and are generally anorthite-rich (Smith and Brothers, 1988; Gamble et al., 1990; Gamble et al., 1993b; Timm et al., 2016).

Timm et al. (2016) recently analysed lavas from both stratovolcanoes from the Rumble II arc massif (Rumble II West and Rumble II East) in the southern Kermadec Arc (Figure 1.2, Figure 2.1), and found fundamental differences associated with magmatic processes between each volcano. Whole rock and mineral compositions of Rumble II East lavas are similar to those of the southern Kermadec Arc-front magmas, whereas whole rock analyses from Rumble II west lavas are characterised by lower levels of $\mathrm{SiO}_{2}, \mathrm{Al}_{2} \mathrm{O}_{3}$ and $\mathrm{TiO}_{2}$. In situ analyses of mineral phases of Rumble II West lavas show olivines with lower forsterite content (Fo-78 to Fo-80) and pyroxenes with lower Mg contents (Mg \# = 65-85) (Timm et al., 2016). Plagioclase phenocrysts from Rumble II West samples have compositions similar to those from Colville Arc samples analysed by Handler et al. (2011), with higher orthoclase content and lower anorthite 
content when compared to arc-front magmas (Figure 2.2). Timm et al. (2016) suggested that both volcanoes are derived from different magma chambers, with a deeper and larger magma chamber associated with Rumble II West, which results in more prolonged fractional crystallisation driving magmatism.

There is general agreement that the compositions of Kermadec Arc magmas are modified by variable contributions from aqueous fluid and sediment melt slabderived components in the mantle wedge (e.g. Haase et al., 2002; Wysoczanski et al., 2006). Northern Kermadec Arc lavas are enriched in LILE, indicative of aqueous fluid enrichment, and have isotopic and LREE/HFSE patterns that indicate minimal contribution from sediment melt. Haase et al. (2002) suggested that the aqueous fluid component phase originates from altered MORB with rutile as a residual phase. In the southern Kermadec Arc, samples show greater enrichments in LILE and LREE compared with northern Kermadec Arc lavas, and indicate a larger contribution from sediment melt in the slab-component, consistent with deeper subduction at slower rates in the south (Haase et al., 2002; Wysoczanski et al., 2006). Mixing of locally subducting sediment and the ambient mantle have also been regarded to contribute to the slab-derived component in the southern Kermadec Arc, and is reflected in the isotopic compositions of the southern Kermadec arc and back-arc lavas (e.g. Gamble et al., 1996). Variations in REE patterns and isotopic signatures of southern KAHT magmas have recently been attributed to interaction with material derived from the subducting Hikurangi Plateau, which has been inferred to have initially occurred $~ 250$ $\mathrm{km}$ north of its present-day location (Timm et al., 2014) (Figures 1.1, 1.3). Timm et al. (2014, 2016) suggested that a heterogeneous mélange layer forms above the subducting plate and interacts with slab-derived fluids and melts. Compositions of Rumble II lavas analysed by Timm et al. (2016) suggest that lateral extent of melange does not extend to the magma source for Rumble II West.

The composition of the present-day KAHT ambient mantle wedge prior to the addition of subduction-derived components has been addressed in a number of studies (Gamble et al., 1993a, 1994; Woodhead et al., 1993; Ewart et al., 1998; Haase et al., 2002), and is widely regarded to be depleted Pacific mid-ocean ridge-type basalt (NMORB), that also shows regional heterogeneity. Along arc, the extent of depletion increases in the northern KAHT, consistent with increasing back-arc widening and 
extension rates to the north, as well as decreasing dip of the subducting slab (Van der Hilst, 1995). Across-arc, the extent of depletion decreases away from the arc front, consistent with what has been observed in other arc-back-arc systems (e.g. Izu-Bonin arc), where depletion occurs as a result of progressive melt extraction during trenchward advection (e.g. Hochstaedter et al., 2000). Todd et al. (2010, 2011) recently analysed southern Havre Trough samples unmodified by subduction, and found that both enriched (high- $\mathrm{Nb}$, enriched isotopic $\mathrm{Hf}$ and $\mathrm{Pb}$ ) and depleted (DMM) components are present in the ambient mantle, with the extent of enrichment greater away from the arc-front. They suggested that isotopic heterogeneity in the southern Havre Trough can be explained by progressive melt extraction of the enriched component during recent trenchward advection, and/or as a result of remnant arc and back-arc magmatism depleting an enriched mantle during the last $\leq 25 \mathrm{Myr}$.

\subsection{Back-Arc Extension in the Southern Kermadec Arc- Havre Trough}

Extension in arc-back-arc systems progresses over time, from tectonically controlled rifting in immature back-arc basins such as the Havre Trough (Taylor, 1992; Wright, 1993; Parson and Wright, 1996; Delteil et al., 2002), to magmatically controlled spreading in mature back-arc basins such as the Lau Basin (Taylor et al., 1996; Martinez and Taylor, 2006), where magmatism is characterised by full-ocean spreading. Back-arc basins can have complex tectonic histories, where episodes of rift migration and propagation of spreading centres make it difficult to reconcile the magmatic evolution of an arc-back-arc system using archetypal models that predict a progressive change in the composition of back-arc basin basalts (BABB) from being predominantly arc-like to more MORB-like, with increasing distance from the trench (Martinez and Taylor, 2003). Back-arc extension may be in a transitional stage between amagmatic rifting and accretionary spreading, where there is both thinning of older arc crust and asymmetric accretion of intrusive volcanism in multiple, disorganised, short spreading ridges (Martinez and Taylor, 2006). Crustal accretion in these spreading ridges may occur in the back-arc, arc-front or fore-arc regions of an arc-back-arc system, and can therefore result in the juxtaposition of magmas derived from flux-melting in the mantle wedge and adiabatic decompression melting 
(Martinez and Taylor, 2006). An implication of this model is that the composition of back-arc magmas reflects the stage of magmatism during back-arc evolution, which is affected by the interaction and proportion of decompression-derived melts and fluxderived melts, as well as their relative positions.

Despite being one of the first back-arc basins identified (e.g. Karig, 1970) the structural evolution of the Havre Trough is poorly constrained. Early interpretations of aeromagnetic survey data in the Havre Trough were interpreted to show active ocean spreading (Malahoff et al., 1982). Subsequent initial studies of the Havre Trough have involved the use of airborne magnetic and gravity data, single-track reconnaissance lines and bathymetric mapping in localised regions, as parts of wider studies in the KAHT (e.g. Caress, 1991). These studies resulted in the discovery of short, deep en-echelon rifts in the southern Havre Trough, which were initially interpreted as evidence for active spreading. However, swath bathymetric mapping and imagery data in the southernmost region of the Havre Trough did not find an axial spreading centre, which led Wright et al. (1996) to interpret the morphology of the southern Havre Trough to be comprised of a contiguous system of en-echelon rifts and that the initial aeromagnetic anomalies were associated with magmatic intrusives between rift blocks comprised of arc basement material, as opposed to oceanic spreading. As a result, the Havre Trough was then widely regarded to be associated with back-arc rifting. These initial studies however, have only provided piecemeal representations of the structure and morphology of the Havre Trough back-arc. It was not until detailed surveying was undertaken in 2006 during the $R / V$ Yokosuka YK-06 voyage, where the entire width of the back-arc in the south was studied, that the first detailed overview of the structure, morphology, and backscatter reflectivity of the southern Havre Trough (e.g. Wysoczanski et al., 2010) was obtained (Figure 2.1).

Data acquisition during the $R / V$ Yokosuka YK-06 voyage has revealed that the southern Havre Trough is comprised of sub-equal regions of basal plateaux that have a mean depth of 2500-3000 mbsl and are surmounted by volcanic seamounts and ridges, and short-segment, deep rifts that exceed depths greater than 4000 mbsl. Backscatter reflectivity show a low signal for the crustal plateaux, and a high reflective signal for seamounts, ridges, and the deep rifts. The plateaux, volcanic edifices and ridges are considered to define a constructional 'arc regime' in the Havre Trough, and 
the deep rifts are considered to define a basinal 'rift regime' (Wysoczanski et al., 2010). Deep-tow camera dives and dredge sampling undertaken in the Ngatororirangi rift has resulted in the discovery of a constructional axial ridge on the rift floor, as well as fresh pillow and lobate lava flows with thin manganese coats and sediment cover, characteristic of recent, young volcanism. The apparently young volcanism that floors the deep rifts of the Havre Trough has led Wysoczanski et al. (2010) to suggest that they could be characterised by present-day rifting, or nascent 'disorganised' seafloor spreading, where asymmetric crustal accretion occurs as a result of intrusive volcanism at short, deep, failed, active rifts (Figure 2.1). The morphology of the deep rifts in the southern Havre Trough resembles that of the southern Valu Fa Ridge (VFR) and Western Lau Basin (WLB), both of which are widely considered to be in a phase of nascent 'disorganised' spreading, prior to the development of a mature oceanic spreading centre as exemplified in the Lau Basin (Martinez and Taylor, 2006).

Despite these recent detailed studies in the southern Havre Trough, the relationship between magmatism and rifting still remains largely unknown. In comparison to the arc-front, data from very few samples from the deep rifts have been reported, and their structure, as well as the age of recent magmatism, is not wellconstrained. Previous analyses have demonstrated that they have a wide range of compositions, including archetypal BABB which are MORB-like in composition, as well as basalts which are more arc-like (Gamble et al., 1994; Haase et al., 2002; Wysoczanski et al., 2006). Todd et al. (2011) recently demonstrated that compositions of samples from the Havre Trough back-arc rifts can be attributed to a subduction slab component where material gets transferred to the mantle wedge as supercritical fluids at greater depths. High-backscatter reflectivity could reflect recent magmatism intruding into older extending crust, or the accretion of new crustal material (Wysoczanski et al., 2010). In recent years, samples from the southern Havre Trough back-arc basins have been collected using dredge sampling during the $R / V$ Tangaroa voyages TAN1007, TAN1213, and TAN1513. Analyses of samples of the back-arc basins from the western Havre Trough have been included in this study, to form a baseline composition of the ambient mantle wedge prior to the addition of the slab flux required for the construction of stratovolcanoes at $\sim 34.5^{\circ} \mathrm{S}$. 


\subsection{Sampling Locations}

Samples of fresh pillow lavas erupted back-arc stratovolcanoes (Gill Seamount, Rapuhia Seamount, Yokosuka Seamount and Giljanes Seamount) and adjacent back-arc rifts (western Havre Trough Back-arc Basins) of the southern KAHT were collected during recent marine voyages on the $R$. V. Tangaroa (TAN0205 in 2002, TAN1007 in 2010 and TAN1513 in 2015) (Table 1.1). In addition, highresolution multi-beam mapping has been undertaken on each rift and edifice, and has revealed stratovolcanoes to be located in deep rifts and on crustal plateaux (e.g. Wright et al., 2006; Wysoczanski et al., 2010) (Section 1.2.2).

The back-arc volcanoes are aligned orthogonal to the trend of the Kermadec Trench, and thus provide a unique opportunity to investigate how subduction contributes to arc magmatism in the Havre Trough Back-arc and how it varies with increasing distance from the arc-front, as well as processes that modify the composition of lava suites from each stratovolcano. The first samples of the back-arc stratovolcanoes were collected during the R.V. Tangaroa TAN0205 and were analysed by Wright et al. (2006). This work adds to the initial set of analyses of back-arc stratovolcanoes in the southern KAHT, and includes analyses of fresh samples that have been subsequently collected during the R.V. Tangaroa TAN1007. A brief description of each back-arc stratovolcano and back-arc basin follows, and a brief list of each sample collected for this study is presented in Appendix A1.

\subsubsection{Western Havre-Trough Back-Arc Basin}

Back-arc basins in the western Havre Trough were first discovered, and subsequently mapped, during the $R / V$ Yokosuka voyage YK06-14 (Wysoczanski et al., 2010), and reach depths $>2000$ mbsl (Figure 2.1). To date, no analyses from volcanic rock samples recovered from these basins have been reported. Dredge sampling undertaken in the western Havre Trough during the $R / V$ Tangaroa TAN1513 recovered mafic clasts, vesicular pillow basalts with glassy rims, and pillow lava with thin $(<1 \mathrm{~mm})$ manganese crusts. Six samples were selected and have been analysed in this study. 
a)

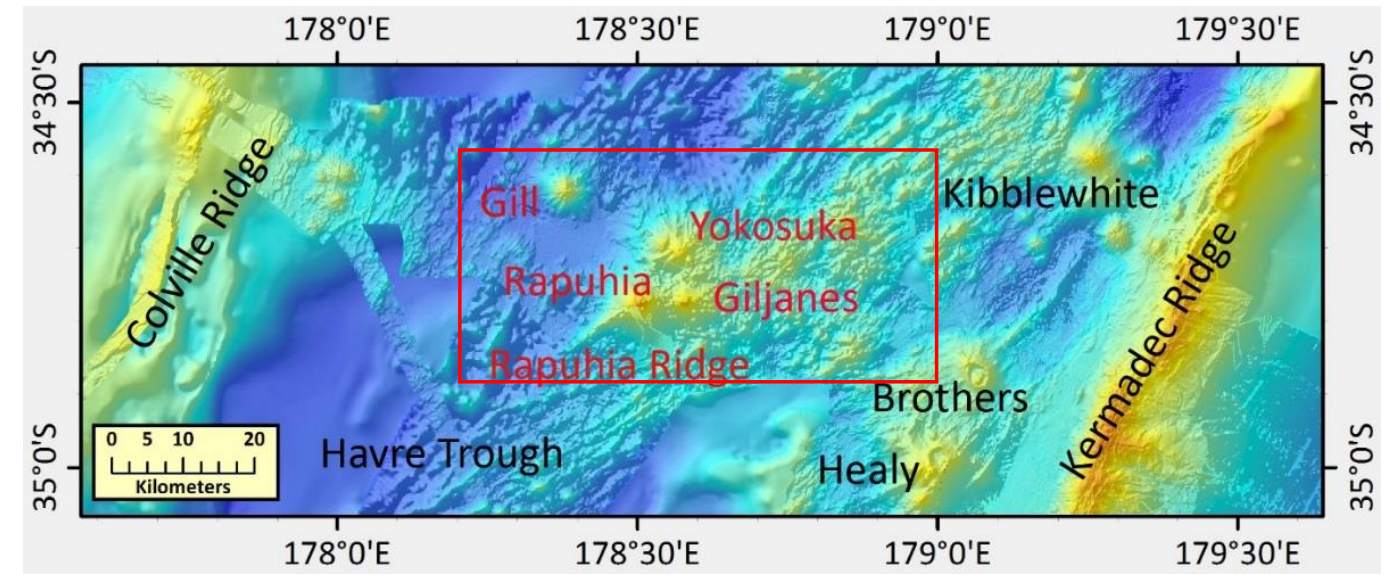

b)

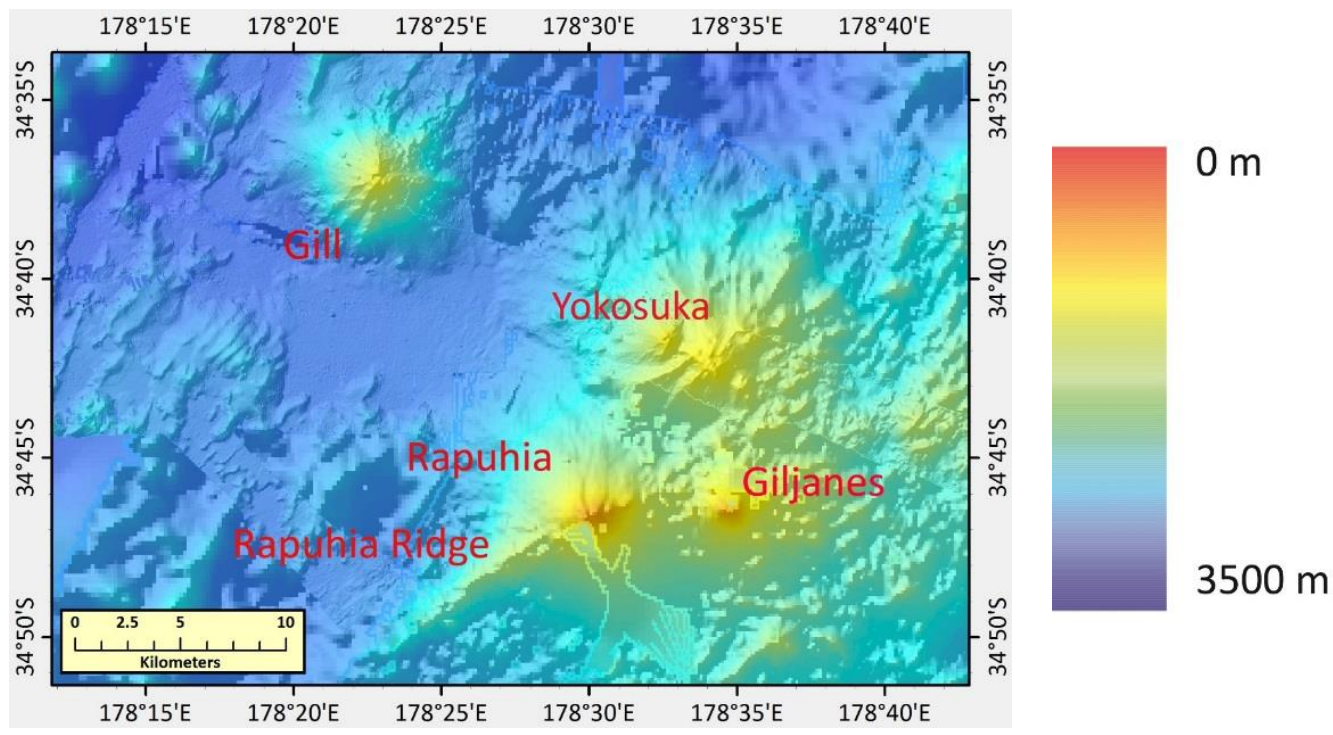

Figure 2.4. Digital topographic maps of the ocean floor between the Kermadec Ridge and the Colville Ridge, showing the back-arc stratovolcanoes investigated in this study.

a) Map showing location of all back-arc stratovolcanoes investigated in this study in southern Havre Trough relative to Kermadec Arc volcanic-front. b) Magnified view of the back-arc stratovolcanoes. Bathymetric key applies for both maps. Images courtesy of NIWA. 


\subsubsection{Back-Arc Stratovolcanoes}

The back-arc volcanoes investigated in this thesis are located in the southern Havre Trough, between $34.3-34.5^{\circ} \mathrm{S}$, and 178.28 - $178.35^{\circ} \mathrm{E}$ (Table 2.1). Owing to limited sample collection, their eruption histories and magmatic evolutions are unknown, with no marine core sampling. Analyses of collected whole rock fresh lava samples that are presented in this thesis provides the first constraints on magmatic evolution of constructional back-arc volcanism at $\sim 34.5{ }^{\circ} \mathrm{S}$ in the southern KAHT, a region analogous to the Rumble $\mathrm{V}$ Ridge that was previously analysed by Todd et al. (2010).

\begin{tabular}{|c|c|c|c|c|c|c|}
\hline Volcano & $\begin{array}{c}\text { First } \\
\text { Discovered }\end{array}$ & Latitude & Longitude & $\begin{array}{c}\text { Basal Diameter } \\
(\mathbf{k m})\end{array}$ & $\begin{array}{c}\text { Relief } \\
(\mathbf{m})\end{array}$ & $\begin{array}{l}\text { Constructional } \\
\text { Volume }^{3}\left(\mathbf{k m}^{3}\right)\end{array}$ \\
\hline Gill & 2006 & $178^{\circ} 28.88^{\prime} \mathrm{E}$ & $34^{\circ} 37.17^{\prime} \mathrm{S}$ & 6.3 & 1800 & 68 \\
\hline Rapuhia & 2002 & $178^{\circ} 30.32^{\prime} \mathrm{E}$ & $34^{\circ} 46.57^{\prime} \mathrm{S}$ & 8 & 1600 & 48.6 \\
\hline Yokosuka & 2002 & $178^{\circ} 32.72^{\prime} \mathrm{E}$ & $34^{\circ} 42.54^{\prime} \mathrm{S}$ & 12 & 1440 & 52.4 \\
\hline Giljanes & 2002 & $178^{\circ} 34.72^{\prime} \mathrm{E}$ & $34^{\circ} 46.49^{\prime} \mathrm{S}$ & 7 & 900 & 39.9 \\
\hline Ruapehu & & & & & & 150 \\
\hline Taranaki & & & & & & 30 \\
\hline
\end{tabular}

Table 2.1. Stratovolcanoes investigated in this study. Constructional volumes for Rapuhia seamount, Yokosuka seamount, and Giljanes seamount come from Wright et al. (2006). Constructional volumes for Ruapehu and Taranaki are shown for comparison, and come from Wright (1994) and Conway et al. (2016).

\section{Gill Seamount}

Gill Seamount $\left(\sim 178^{\circ} 28.88^{\prime} \mathrm{E},-34^{\circ} 37.17^{\prime} \mathrm{S}\right)$ (Table 2.1$)$ is located near the middle of the southern Havre Trough (Wysoczanski et al., 2010), 66 km to the east of the Colville Ridge, $\sim 13 \mathrm{~km}$ to the west of Yokosuka, and $\sim 72 \mathrm{~km}$ to the west of Kibblewhite Seamount on the arc-front (Figures 1.1, 2.1, 2.4, 2.5). Gill Seamount was first discovered, and subsequently mapped, as a result of multi-beam data acquisition undertaken during the $R / V$ Yokosuka voyage YK-06 in 2006 using a $12 \mathrm{kHz}$ SEABEAM system (Wysoczanski et al., 2010) (Table 1.1), and re-mapped during the $R / V$ Tangaroa voyage TAN1007 in 2010 using a Kongsberg EM300 multi-beam echosounder. To date, it is the most distal back-arc stratovolcano that has been identified in the KAHT (Wysoczanski et al., 2010). Unlike the other back-arc stratovolcanoes located to the east, Gill Seamount was constructed over a rifted back-arc basin 3000

\footnotetext{
${ }^{3}$ The constructional volumes for Rapuhia Seamount, Yokosuka Seamount and Giljanes Seamount were calculated by using bathymetric terrain models that were defined individually for each volcano. The constructional volume for Gill Seamount was calculated using estimates of the height, and radius from (Figure 2.5).
} 
mbsl (Sections 1.2.2, 1.3). This back-arc basin is associated with the western Havre Trough.

The edifice of Gill Seamount comprises a single stratocone which has a basal diameter of $\sim 12 \mathrm{~km}$ by $\sim 14 \mathrm{~km}$ that rises to $\sim 1200 \mathrm{mbsl}$, and has a relief of $\sim 1800 \mathrm{~m}$ (Table 2.1). The summit crater at the peak of Gill Seamount has a diameter of $\sim 1 \mathrm{~km}$, and forms a continuous rim. Minor ridges protrude from the northern and north-eastern flanks. Minor parasitic cones are located on the back-arc basin to the north of the main edifice. Multi-channel seismic (MCS) surveying undertaken during the $R / V$ Tangaroa research voyage TAN1007 traversed the southern flank of Gill Seamount, and revealed normal faults dissecting the southwestern flank, and volcaniclastic material

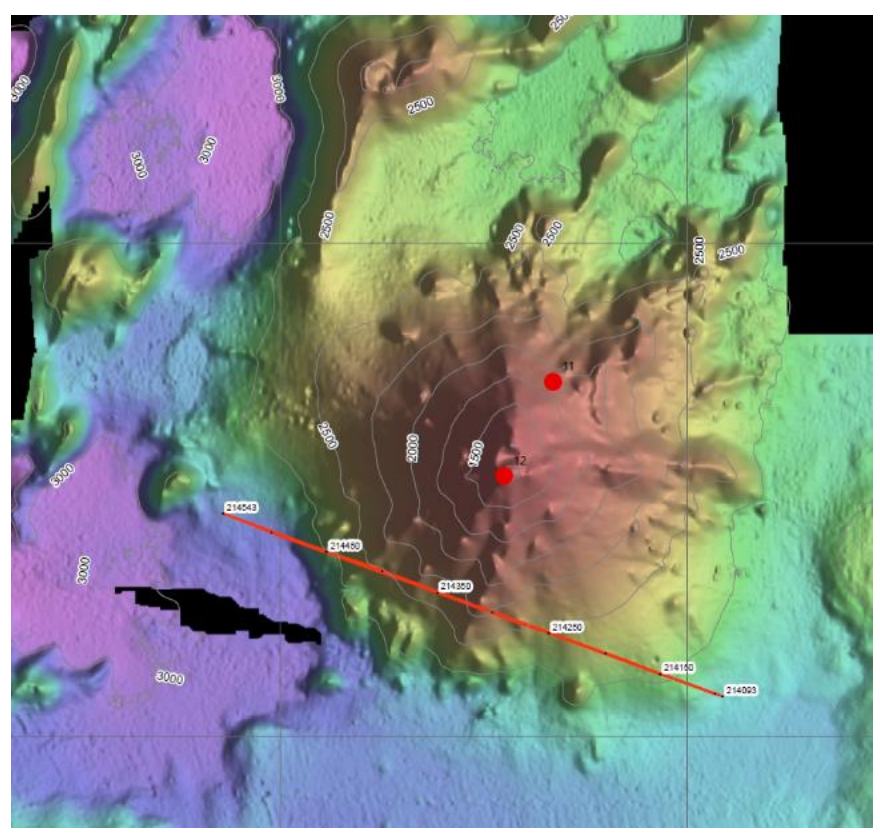

Figure 2.5 Map of Gill Seamount, in the southern KAHT. Red line represents MCS survey undertaken during the R/V Tangaroa TAN1007. Red circles correspond to dredge sites during the R/V Tangaroa TAN1007, from which collected material has been analysed for this study. Black regions denote areas not mapped. Image courtesy of NIWA.

overlying the eastern flank, as well as the adjacent rift located to the southeast. A single sample collected from the flank of Gill Seamount was analysed by Todd et al. (2011), and is characterised by enriched LILE and Nb. Samples collected the from the flank and north-eastern summit of Gill Seamount during the $R / V$ Tangaroa research voyage TAN1007 include pillow basalts, which have been analysed in this study. 


\section{$\underline{\text { Rapuhia Seamount }}$}

Together with Yokosuka Seamount and Giljanes Seamount, Rapuhia Seamount comprises a group of closely spaced stratovolcanoes located in the middle of the southern Havre Trough $\left(\sim 34.5^{\circ} \mathrm{S}, 178.5^{\circ} \mathrm{E}\right)$, (Figure 2.2). These three stratovolcanoes were first discovered during the $R / V$ Tangaroa voyage TAN0205 in 2002, and mapped using a Kongsberg EM300 multi-beam echo-sounder (Wright et al., 2006). They are located $\sim 45 \mathrm{~km}$ to the west of the arc-front, and surmount an elevated basal plateau 2500 mbsl (Wright et al., 2006), similar to the plateau underneath the Rumble V Ridge (Wright et al., 1996). The origin and composition of the plateau is unknown. When compared with the back-arc basins and stratovolcanoes, the plateau is characterised by low backscatter reflectivity (Wysoczanski et al., 2010), and has been suggested to reflect a remnant massif block associated with the Colville Arc (Wright et al., 2006), but may be comprised of sedimentary material (Wysoczanski and Clark, 2012). The western Havre Trough back-arc rift is located to the west (Figures 1.1, 2.1, 2.4). Previous analyses of samples collected from the summit of each stratovolcano during the $R / V$ Tangaroa voyage TAN0205 are reported in Wright et al. (2006), and have been included in this study. Trace element analyses were provided by Haase and Timm, pers. comms. (2006).

Rapuhia Seamount is located to the southwest of Yokosuka Seamount and Giljanes Seamount on the basal plateau (Wright et al., 2006), and shoals from 2500 mbsl to $\sim 650 \mathrm{mbsl}$. The edifice comprises a single pristine stratocone with a basal diameter of $\sim 8 \mathrm{~km}$, and a relief of $\sim 1600 \mathrm{~km}$ and constructional volume of $\sim 48.6 \mathrm{~km}^{3}$ (Table 2.1). Small vents are aligned along $065^{\circ}$ to the northeast of the edifice, and minor slumps have been observed on the northern flank (Wright et al., 2006). Rapuhia Ridge is a fissure ridge that protrudes from the southwestern flank of the main edifice, extending the trend of northeastern aligned vents. Back-scatter imagery undertaken during the $R / V$ Tangaroa voyage TAN0205 indicates that it is characterised by recent magmatism (Wright et al., 2006). Dredge sampling of the summit of the main edifice during the $R / V$ Tangaroa voyage TAN0205 recovered basaltic andesite and dacite, which were inferred by Wright et al. (2006) to be unrepresentative of the most recent volcanism. Subsequent dredge sampling was undertaken during the $R / V$ Tangaroa voyage TAN1007, and Fe-oxidised rocks and basaltic lavas were collected from the main edifice flank, and pumice blocks and vesicular basaltic lavas were collected from 
Rapuhia Ridge. Only fresh basaltic lava from each dredge location have been analysed for this study.

\section{Yokosuka Seamount}

Yokosuka Seamount is located to the northeast of Rapuhia Seamount (Wright et al., 2006). It is the largest of the three closely associated stratovolcanoes, with a constructional volume of $\sim 52.4 \mathrm{~km}^{3}$ (Table 2.1) (Figures 1.1, 2.1, 2.3). It shoals from $\sim 2500 \mathrm{mbsl}$ to a height of $1060 \mathrm{mbsl}$, and has a basal diameter of $\sim 12 \mathrm{~km}$ and relief of $\sim 1440 \mathrm{~km}$ (Wright et al., 2006). When compared with Rapuhia Seamount, the edifice appears more denuded, with a number of ridges protruding from the flanks, and a sector collapse failure planes, in particular on the northwestern flank (Wright et al., 2006). Parasitic cones are located to the east, as well as overlying failure planes on the northwestern flank (Wright et al., 2006). Multichannel seismic (MSC) data acquisition during the $R / V$ Tangaroa TAN1007 resulted in the discovery of two crests on the summit of the edifice, as well as normal faults dissecting the western flank. Dredge sampling of the summit of the main edifice during the $R / V$ Tangaroa voyage TAN0205 recovered altered dacite, pumice, and andesite, with analyses reported in Wright et al. (2006). Analyses provided by Haase and Timm, pers. comms. (2006) have been included in this study.

\section{Giljanes Seamount}

Giljanes Seamount $\left(-34^{\circ} 46.491^{\prime} \mathrm{S}, 178^{\circ} 34.723^{\prime} \mathrm{E}\right)$, is the easternmost of the cluster of three stratovolcanoes, and is located due east of Rapuhia Seamount (Wright et al., 2006), (Figures 1.1, 2.1, 2.3). It is the smallest of the volcanoes in the cluster, with a constructional volume of $\sim 39.9 \mathrm{~km}^{3}$ (Table 2.1). It shoals from $1800 \mathrm{mbsl}$ to $700 \mathrm{mbsl}$, and has a relief of $900 \mathrm{~m}$, and (Wright et al., 2006). The edifice resembles a sub-equant stratocone, with a series of fissure ridges extending from the northeastern flank (Wright et al., 2006). A series of small-scale elongated cones, fissure ridges, and rifts are located to the northeast of Giljanes Seamount (Wright et al., 2006). Dredge sampling, undertaken on the crest during the $R / V$ Tangaroa TAN0205, collected manganese oxides, andesite and basalt-andesite. Previous analyses of 
samples are reported in Wright et al. (2006). An additional basaltic-andesite sample has been analysed for this study, and a previous analysis provided by Haase and Timm, pers. comms. (2006) has also been included. 


\section{Chapter 3: \\ Analytical Techniques}




\subsection{Whole Rock Sample Preparation}

Given that the samples come from rocks that were collected from the seafloor, contamination from sediment and seawater was an important consideration in preparing samples for chemical analysis. For example, the sodium content of a sample can be contaminated by crystals of sodium chloride that have precipitated from seawater (Tani et al., 2005). Contamination from seawater and sediment will especially affect highly vesicular samples, because sediment and saltwater can percolate through interconnected vesicles and come into contact with the interior of the rock. A meticulous cleaning method is therefore required to ensure that only clean, non-contaminated material is used for any analytical techniques.

Whole rock samples were first cut into billets using a diamond-bladed saw, and billets of only the fresh core of a rock sample were processed further. This process is important for removing altered surfaces and/or xenoliths. During this step, it was important to ensure that samples were cut into billets $>15 \mathrm{~mm}$ thick, so that the billets represented the bulk rock composition, without the removal of coarse minerals, which would affect the homogeneity of the sample. For each sample, a billet was put aside to be prepared into a thin section. After the billets were visually checked for alteration and contaminants, each sample was individually polished using a diamond-surfaced lap to remove any metal contamination from the diamond saw that may have occurred during rock cutting.

Sample billets were then washed and boiled in glass beakers using Millipore ${ }^{\circledR}$ $\mathrm{H}_{2} \mathrm{O}$ (Milli-Q water, filtered ultra-clean water with a resistivity $>18.2 \mathrm{M} \Omega$ ). It was during this step that contamination from seawater was removed. The beakers were placed on a hot plate, and boiled for 15-20 minutes. During each cycle of washing, the concentration of total dissolved solids (TDS) of the boiled water was measured using an Oakton ${ }^{\circledR}$ EcoTestr TDS Low tester. After boiling, the $\mathrm{H}_{2} \mathrm{O}$ and any loose material was discarded and replaced with fresh Milli-Q $\mathrm{H}_{2} \mathrm{O}$. This process was repeated until the concentration TDS of the boiled water closely matched that of the fresh Milli-Q $\mathrm{H}_{2} \mathrm{O}(0-10 \mathrm{ppm})$, or alternatively, if a solution of silver nitrate was added to the boiling water and did not result in the precipitation of a cloud of silver nitrate, indicating that the sodium chloride had been removed. Each sample underwent $\sim 20-35$ cycles of washing, to ensure that all the salt, and as much sedimentary material as possible, had 
been removed. Once devoid of saltwater contamination, the samples were then dried in an oven at at least $60^{\circ} \mathrm{C}$ for 12 hours.

After the samples had been cleaned and dried, 60-180 $\mathrm{g}$ of the freshest material from the billets was selected for crushing for whole rock analysis. The billets were crushed in a Rocklabs Boyd crusher. Before each sample was crushed, the Boyd crusher was meticulously cleaned using ethanol and compressed air to remove any material from prior analyses which may not have been removed from the crushing jaws. The samples were crushed to 1-2 mm sized grains. To ensure that the final milled sample was fully represented, all of the crushed material, including all the fine material, was collected and used for milling. The crushed material from each sample was then ground and reduced to a fine powder (grain size ca. $75 \mu \mathrm{m}$ ) using an agate disc mill. Prior to milling each sample, $60-80 \mathrm{~g}$ of pure silica sand was milled to reduce the effects of contamination of grinding from previous samples. An agate mortar and pestle was used to grind samples into powders where the total mass of the material of the crushed sample was $<40 \mathrm{~g}$.

\subsection{Whole Rock Major Element Geochemistry Analysis}

Fourty-four whole rock samples were prepared for major element analysis, and compositions were determined by X-Ray fluorescence (XRF) spectrometry, following the methods of Ramsey et al. (1995). Whole rock powders were fused into glass disks at SpectraChem Analytical, CRL Energy Ltd. Disks were prepared using a type 1.2:2.2 mixed lithium tetraborate and lithium mataborate flux, and a sample : flux ratio of 10:1. Analysis of fused disks was performed by Richard Wysoczanski at NIWA, using a Panalytical Minipal-4 XRF spectrometer and a calibration curve based on 12 international silicate standards. Certified international USGS standards BHVO-2 and BCR-2 were analysed during the same sessions to monitor precision and accuracy. Two standard deviations for each element (2 SD), determined by 3 replicate analyses of BHVO-2 and 4 of BCR-2, are generally $<2 \%$ relative. Average values for each standard are in close agreement with the certified values (generally within 1-3\% relative), indicating a high degree of accuracy in each analysis. 


\subsection{Whole Rock Trace Element Geochemistry Analysis}

\subsubsection{Laboratory Protocol and Beaker Preparation}

Thirty-nine whole rock samples were selected in this study for trace element analysis, and were prepared in the ultra-clean geochemistry laboratory at Victoria University of Wellington, which contains four Class 10 laminar flow workstations, and is positively pressured with Class 100 filtered air. These conditions allow for minimal risk of contamination. All the water used during sample preparation for trace element analysis was Milli-Q water with a resistivity of $>18.2 \mathrm{M} \Omega$. The only acids that were used for the sample dilution of trace element sample digestion and dilution were Optima $^{\mathrm{TM}}$ ultra-pure grade acids (all key metals $<10 \mathrm{ppt}$ ). Analytical reagent grade acids were used for early stages of sample beaker cleaning.

Prior to acid digestion, $23 \mathrm{~mL}$ Savillex Teflon ${ }^{\mathrm{TM}}$ beakers underwent a series of cleaning procedures to ensure that they were devoid of contamination. Beakers were first rinsed and wiped down using methanol and then soaked in $6 \mathrm{M} \mathrm{HCl}$ on a hotplate at $120^{\circ} \mathrm{C}$ for at least 24 hours, followed by three rinses in Milli-Q water. Beakers were then soaked in $7 \mathrm{M} \mathrm{HNO}_{3}$ on a hotplate for another 24 hours, followed by another three rinses in Milli-Q water. The final cleaning steps involved refluxing the beakers for at least 24 hours using 4-5 $\mathrm{mL}$ of 6-7 $\mathrm{M}$ of sub-boiled $\mathrm{HNO}_{3}$, followed by three rinses in Milli-Q water. This step was then repeated using 6-7 M Optima ${ }^{\mathrm{TM}}$ ultra-pure grade $\mathrm{HNO}_{3}$, followed by three rinses in Milli-Q water.

\subsubsection{Sample Digestion}

All the samples used for inductively coupled plasma mass spectrometry (ICPMS) analysis came from the same powder batches that were used for XRF major element analysis. Samples were prepared and analysed in three separate batches. For each batch, international standards BHVO-2 and BCR-2, and a full blank, were prepared and analysed under identical conditions to those used for preparation of the sample powders. For each sample, 50-100 mg of powder was weighed in a pre-cleaned $23 \mathrm{~mL}$ Savillex Teflon ${ }^{\mathrm{TM}}$ beaker, using a high precision balance (to $\pm 0.0001 \mathrm{~g}$ ). The samples and international standards were then dissolved following conventional digestion methods, using $~ 12$ drops of concentrated nitric acid (16 $\left.\mathrm{M} \mathrm{HNO}_{3}\right)$, and 55- 
60 drops of concentrated hydrofluoric acid (29 M HF). The powder and acid mixtures were heated in sealed Savillex beakers at $120^{\circ} \mathrm{C}$ for 3-4 days to ensure that the samples were completely digested.

Once the samples were fully digested, the solutions were evaporated to incipient dryness at $120^{\circ} \mathrm{C}$. Extreme care was taken to ensure that the samples were not over-dried, which can result in sample loss and/or the formation of insoluble flourides. To ensure that any residual HF was removed from the solution, the samples were evaporated twice in $\sim 2 \mathrm{~mL}$ of concentrated $\mathrm{HNO}_{3}$. Samples were then refluxed in $\sim 4 \mathrm{~mL}$ of half concentrated hydrochloric acid $(6 \mathrm{M} \mathrm{HCl})$ at $120^{\circ} \mathrm{C}$ overnight. After the samples were visually checked to ensure that they were fully in solution, the $\mathrm{HCl}$ was evaporated to dryness. The sample cakes were then covered with concentrated $\mathrm{HNO}_{3}$ and evaporated, to convert the samples back to nitric form. Nine $\mathrm{mL}$ of $1 \mathrm{M}$ $\mathrm{HNO}_{3}$ was added to each sample, which were then refluxed at $120^{\circ} \mathrm{C}$ for a further $1-2$ days. The samples were visually checked to ensure that they were fully in solution.

The final solutions were quantitatively transferred into pre-cleaned $10 \mathrm{~mL}$ polyethylene centrifuge-tubes, and weighed on a high-precision balance (to \pm 0.0001 g). The tubes were then centrifuged at $2000 \mathrm{rpm}$ for 10 minutes, and checked visually to ensure that no solids or precipitants were present in the solutions. A dilution of each sample was prepared by transferring and precisely weighing an aliquot of the final solution into another pre-cleaned $10 \mathrm{~mL}$ centrifuge tube using a high precision balance (to $\pm 0.0001 \mathrm{~g}$ ). Each aliquot was topped up with ca. $10 \mathrm{~mL}$ of $1 \% \mathrm{HNO}_{3}$, and weighed again, so that a dilution factor could be accurately calculated for each sample.

\subsubsection{ICP-MS Analysis}

Whole rock trace element analysis was performed by solution inductively coupled plasma mass spectrometry (ICP-MS), using a Thermo-Fisher Element2 sector-field ICP-MS at Victoria University of Wellington, where each sample solution was introduced using an attached Elemental Scientific Inc. (ESI) auto-sampler, and passed through a micromist nebuliser. Tuning of the ICP-MS was performed using a $1 \mathrm{ppb}$ multi-element standard tuning solution, where instrument parameters such as the torch position and carrier/make-up gas flow were adjusted to obtain minimal 
relative standard deviation (RSD), and to optimise sensitivity. Oxide generation was monitored using measured ratios of $\mathrm{BaO}^{+} / \mathrm{Ba}^{+}(0.1-0.2 \%), \mathrm{Ba}^{++} / \mathrm{Ba}^{+}(5.3-6.3 \%)$, and $\mathrm{UO}^{+} / \mathrm{U}^{+}$(4.1-7.0\%). ICP-MS analysis was performed using low mass resolution for the majority of masses, but the resolution was increased to medium resolution for selected masses (e.g. $\mathrm{Mg}, \mathrm{Al}, \mathrm{Ca}, \mathrm{Sc}, \mathrm{V}, \mathrm{Cr}, \mathrm{Mn}, \mathrm{Co}, \mathrm{Ni}$. Cu, $\mathrm{Zn}, \mathrm{Ga}$ ), to ensure that elemental counts were not affected by spectral interferences, and/or that elemental counts were reduced for particularly abundant masses that may otherwise overload the detector.

Sample solutions were measured for a total time of 145 s. Following each sample analysis, the ICP-MS and auto-sampler lines were washed using one rinse in $1 \%$ Optima $\mathrm{HNO}_{3}$ for $180 \mathrm{~s}$. Analytical runs were performed in a looping sequence starting with primary standard (BHVO-2), secondary standard (BCR-2), five samples, and finishing with the primary standard. Background counts were measured periodically throughout each sequence also for $145 \mathrm{~s}$, before each primary standard and after each secondary standard, using a $1 \%$ Optima $\mathrm{HNO}_{3}$ acid blank.

Concentrations for each sample were calculated by sample-standard bracketing, using the USGS standard BHVO-2 as a calibration standard, and USGS standard BCR-2 as a secondary standard to evaluate the accuracy of each analysis. Elemental abundances for both standards were obtained from the GeoReM database of preferred values (Jochum et al., 2016). Count rates for each mass were determined by subtracting background counts per second (CPS) analyses of acid blanks from the CPS analyses for each sample and standard, with the blank that was analysed closest to the sample/or standard was selected for subtraction. Concentrations were then calculated for the adjusted count rates, relative to the bracketing calibration standard BHVO-2, using the following relationship:

$$
\text { Equation 1: } \quad \text { Sample } \mathrm{C}_{\mathrm{i}}=\left(\text { Sample }_{\mathrm{CPS}} / \mathrm{BHVO}_{\mathrm{CPS}}\right) \times\left(\text { Sample }_{\text {Dil }} / \mathrm{BHVO}_{\text {Dil }}\right) \times \text { Ref }
$$

where $\mathrm{C}_{\mathrm{i}}$ is the concentration of the element of interest, $\mathrm{X}_{\mathrm{CPS}}$ is the CPS of the element of interest after subtraction of background CPS, $\mathrm{X}_{\mathrm{Dil}}$ is the concentration of material in the dilution aliquots, and Ref is the reference value of the BHVO-2 standard.

For each sample, the measured concentration of ${ }^{43} \mathrm{Ca}$ was used as an internal correction for all trace element concentrations analysed by ICP-MS, as for each 
sample, the wt \% of $\mathrm{CaO}$ was analysed by XRF analysis (Section 3.2.1). This allows for any loss of material to be identified and corrected for during sample preparation, using the following relationship:

Equation 2: $\quad$ Sample $\mathrm{C}_{\mathrm{i}}($ Ca corrected $)=$ eq. $(1) \times\left(\mathrm{C}_{\mathrm{Ca}} \mathrm{XRF} / \mathrm{C}_{\mathrm{Ca}} \mathrm{ICP}-\mathrm{MS}\right)$

where $\mathrm{C}_{\mathrm{Ca}}$ is the measured concentration of $\mathrm{Ca}$.

Trace element analyses of secondary standard BCR-2 were accurate to $\leq 3 \%$ of preferred values, with the exceptions of $\mathrm{Li}, \mathrm{Cr}, \mathrm{Cu}, \mathrm{Zn}, \mathrm{Rb}, \mathrm{Cd}, \mathrm{Cs}, \mathrm{W}$ and $\mathrm{Pb}$ (See Appendix A3, Table A3.3).

Reproducibility of sample analyses was tested by ICP-MS analysis of duplicates of three samples (TAN1007-011-03, TAN1007-011-06, TAN1007-011-11) (See Appendix A3, Tables A3.4, A3.5.) Two duplicates were analysed for sample TAN1007-011-11 as it contained abundant coarse phenocrysts. Most elements reproduce to $\leq 7 \%$, with the exceptions of $\mathrm{Li}, \mathrm{Zn}, \mathrm{Rb}, \mathrm{Zr}, \mathrm{Nb}, \mathrm{Cs}, \mathrm{Gd}, \mathrm{Tb}$, Dy, Tm, Hf, Ta, W, Pb and Th and U (See Appendix A3, Table A3.4). The high reproducibility for most elements reflects the high precision of the ICP-MS analytical technique used, as well as the reliability of sample preparation and the fact that the whole rock was represented in powders used for analysis.

\subsection{In Situ Major Element Geochemistry Analysis}

Fifteen samples were selected in this study, and prepared into $40 \mu \mathrm{m}$ polished thin sections for major element analysis by electron probe microanalysis (EPMA). Each thin section was coated with a ca. $25 \mathrm{~nm}$ film of carbon prior to analysis. For each sample, in situ major element compositions were measured on phenocrysts, oxide inclusions within the phenocrysts, and groundmass crystals, using a JEOL JXA 8230 SuperProbe electron probe micro analyser at VUW. The JEOL JXA 8230 SuperProbe is equipped with five wavelength dispersive spectrometers (WDS) that allow for quantitative analyses on selected minerals and glass. The JXA 8230 is also equipped with an energy dispersive X-ray spectrometer (EDS), and detectors that allow for the collection of backscattered electron (BSE) and secondary electron (SEI) images. Petrographic descriptions were carried out to determine the samples most suitable for 
analysis. Samples selected for in situ analysis included samples from dredges from each volcano, to get a broad representation of the whole range of rock compositions. Samples selected for ${ }^{40} \mathrm{Ar} /{ }^{39} \mathrm{Ar}$ isotope analysis were also all analysed by EPMA.

All quantitative analyses on minerals were undertaken using WDS with a focused beam with a 1-2 $\mu \mathrm{m}$ spot diameter, an accelerating voltage of $15 \mathrm{kV}$, and a beam current of $12 \mathrm{nA}$. In cases where minerals were coarse-grained, and if greyscale gradients were observed for minerals in BSE images, both the rim and the interior were targeted. A single analysis was used for fine minerals which showed no greyscale gradients or compositional zoning.

Standards were run to calibrate the EPMA for quantitative measurements to ensure that the effect of matrix compositions was reduced. Natural mineral standards, which are used for elements with high abundance ( $>1 \mathrm{wt} \%)$, were selected that were of a similar composition to the minerals being analysed. A complete list of the natural standards used for each calibration is shown in Table A3.6 in Appendix A3. For elements of a relatively low abundance $(<1 \mathrm{wt} \%)$, synthetic oxide standards were used for calibrations.

All major element concentrations were calculated using the ZAF correction method, where the matrix effects of the mass number, atomic absorbance and fluorescence are corrected for. During each analytical run, calibrated standards were periodically analysed to monitor instrumental drift and to determine the precision and accuracy of each analysis. Calibrated standards include Springwater Olivine, Kakanui Augite, Plagioclase NMNH 115900, Ilmenite NMNH 115900, Magnetite MNMH 115900, Beeson Apatite, Engels Amphibole and Hornblende (See Appendix A3, Tables A3.6, A3.7).

Approximately 2 SD relative analytical precisions are generally $<10 \%$ (most are within 4 \%). Exceptions include $\mathrm{MnO}$ in Springwater Olivine, $\mathrm{CaO}$ in Kakanui Augite, and F in Beeson Apatite.

All the data obtained during EPMA analyses are included in an electronic appendix (Appendix EA.3). 


\subsection{Mineral Separate Geochronology Analysis}

\subsubsection{Mineral Separation and Preparation}

Argon-argon $\left({ }^{40} \mathrm{Ar} /{ }^{39} \mathrm{Ar}\right)$ geochronology is a high precision analytical technique that can be used to place absolute age constraints on volcanic lava flows, and constrain the edifice growth of stratovolcanoes. In the case of basaltic-andesitic lava flows, the most reliable results involve separates of feldspar-rich crystalline groundmass (e.g. McDougall and Harrison, 1999; Conway et al., 2016). Detailed petrographic descriptions were carried out on a range of potential samples, to select the four most suitable samples for ${ }^{40} \mathrm{Ar} /{ }^{39} \mathrm{Ar}$ isotope analysis. Obtaining reliable ${ }^{40} \mathrm{Ar} /{ }^{39} \mathrm{Ar}$ isotope radiometric results requires the samples to contain $<5 \%$ glass in the groundmass volume (to minimise the contribution of excess argon from residual glass), and coarse groundmass plagioclase crystals with a minimum width of $10 \mu \mathrm{m}$ (to avoid recoiling problems: see Fleck et al. (2014)). In this study, four samples from the Gill-Rapuhia suite of lavas were selected for ${ }^{40} \mathrm{Ar} /{ }^{39} \mathrm{Ar}$ isotope analysis, and are shown in (Table 3.1).

In order to ensure a sufficient level of crystalline groundmass feldspar was retained for each analysis, two slabs $(4 \times 4 \times 2 \mathrm{~cm}$ thick) of fresh material were prepared for the four samples selected for ${ }^{40} \mathrm{Ar} /{ }^{39} \mathrm{Ar}$ radiometric dating. The samples were then washed and boiled to remove all seawater contamination (See Section 3.1). They were then crushed using a Rocklabs Boyd Crusher and sieved to obtain a 180-355 $\mu \mathrm{m}$-sized fraction. Phenocrysts and xenoliths were magnetically separated from groundmass grains using an LB-1 barrier-type Frantz magnet. In order to remove any material adhering to the grains, the groundmass separates were washed in water for a minimum of 20 hours using an ultrasonic bath, then washed in acetone, and finally rinsed in de-

\section{Sample}

Volcano

\begin{tabular}{ll}
\hline TAN1007-011-04 & Gill Seamount \\
TAN1007-012-01 & Gill Seamount \\
TAN1007-015-04 & Rapuhia Ridge \\
TAN1007-016-01 & Rapuhia Ridge
\end{tabular}

Table 3.1. Samples selected for high precision ${ }^{40} \mathrm{Ar} /{ }^{39} \mathrm{Ar}$ isotope analysis. Samples are listed from their respective dredges (See Appendix A1). 
ionised water. The samples were then handpicked under a binocular microscope, to remove any remaining xenoliths, phenocrysts, and grains with glass, so that only grains of crystalline groundmass would be analysed. For each sample, 300-400 mg of material was sent for irradiation and analysis.

\subsubsection{Sample Irradiation and Analysis}

Irradiation and isotopic analysis of the groundmass plagioclase separates for each sample were undertaken following the methods of Calvert et al. (2005). Samples were irradiated in the central thimble at the United States Geological Survey (USGS) TRIGA® reactor in Denver, Colorado (Dalrymple et al., 1981). The separates of each sample were shielded from thermal neutrons, and were co-irradiated using the Taylor Creek Rhyolite sanidine as an internal standard (27.87 Ma) (Calvert et al., 2005), to determine the neutron irradiation flux for each sample. The reactor vessel was rotated continuously during irradiation. Heating and isotopic analysis of the samples was performed by Graham Leonard (GNS) and Andrew Calvert (USGS) at the USGS Geochronology Laboratory in Menlo Park, California, which is equipped with an argon ion laser system and a MAP 216 mass spectrometer, described in Dalrymple (1989). Argon gas was extracted from each sample using a Staudacher-type resistance furnace that is connected to an all-metal extraction line. Each sample was incrementally heated in 10-11 steps. Two SEAS AP-10 getters were used to clean the resulting gas extracted from each sample prior to analysis, which was then analysed using a MAP 216 mass spectrometer. 


\section{Chapter 4: Results}




\subsection{General Petrography}

In contrast to subaerial settings, where it is possible for different eruption products to be constrained by observing the eruption stratigraphy in the geologic record, the eruption context is largely unknown for dredged samples of volcanic flows erupted in submarine environments. In this context, the primary method by which different eruption products can be constrained is by the dredge location from which samples were collected, as well as the samples' physical appearance and/or chemical composition.

The samples selected from the back-arc stratovolcanoes Gill, Rapuhia and Giljanes for this study were all initially described in hand specimen form when they were initially collected during dredge sampling (Wright et al., 2006). However, the petrography of these stratovolcanoes remains largely unknown. One aim of this study was to provide the first detailed petrographic descriptions of samples erupted from these stratovolcanoes. The descriptions presented in this section are based entirely on mineralogical and textural features in hand specimen and thin section form. Petrographic descriptions for each sample are included in Appendix A2.

Given that the hand specimens contained altered margins and/or manganese crusts, optical microscopy of thin sections was also used to determine which samples were most suitable for ${ }^{40} \mathrm{Ar} /{ }^{39} \mathrm{Ar}$ isotope geochronology, and was an effective screening method for overall sample diversity and selecting representative samples for whole rock geochemical analysis.

\subsubsection{Petrography of Gill Seamount}

Samples from the summit of Gill Seamount (dredge TAN1007-012) are light grey and commonly contain abundant amygdales. By contrast, samples dredged from the flank of Gill Seamount (dredge TAN1007-011) are dark grey and contain less amygdales. Samples from both dredges have a phenocryst assemblage of olivine + clinopyroxene \pm plagioclase. The samples show a high degree of diversity in the modal proportions of the phenocrysts (5 - 35 vol. \%), vesicularity $(10-30$ vol. \%) and groundmass (45 - 80 vol. \%), within and between samples from each dredge location. Modal abundances of a given phenocryst phase also show strong variation between 
samples from both dredges.

Clinopyroxene is generally the most abundant phenocryst crystal phase in samples and comprises $~ 25-85$ vol. \% of phenocrysts within a given sample (Figure 4.1). Clinopyroxene is typically present as isolated euhedral to subhedral crystals, but may also be present with olivine and/or pyroxene in a glomerocryst. Most phenocrysts are $2-4 \mathrm{~mm}$, but some are as coarse as $8 \mathrm{~mm}$. Phenocrysts $<1 \mathrm{~mm}$ are also present in some samples. Many examples display simple twinning. The margins of some phenocrysts are embayed, and alteration is commonly observed along crystal margins. Inclusions of olivine and crystalline material are common, and weak zoning is observed in a few examples.

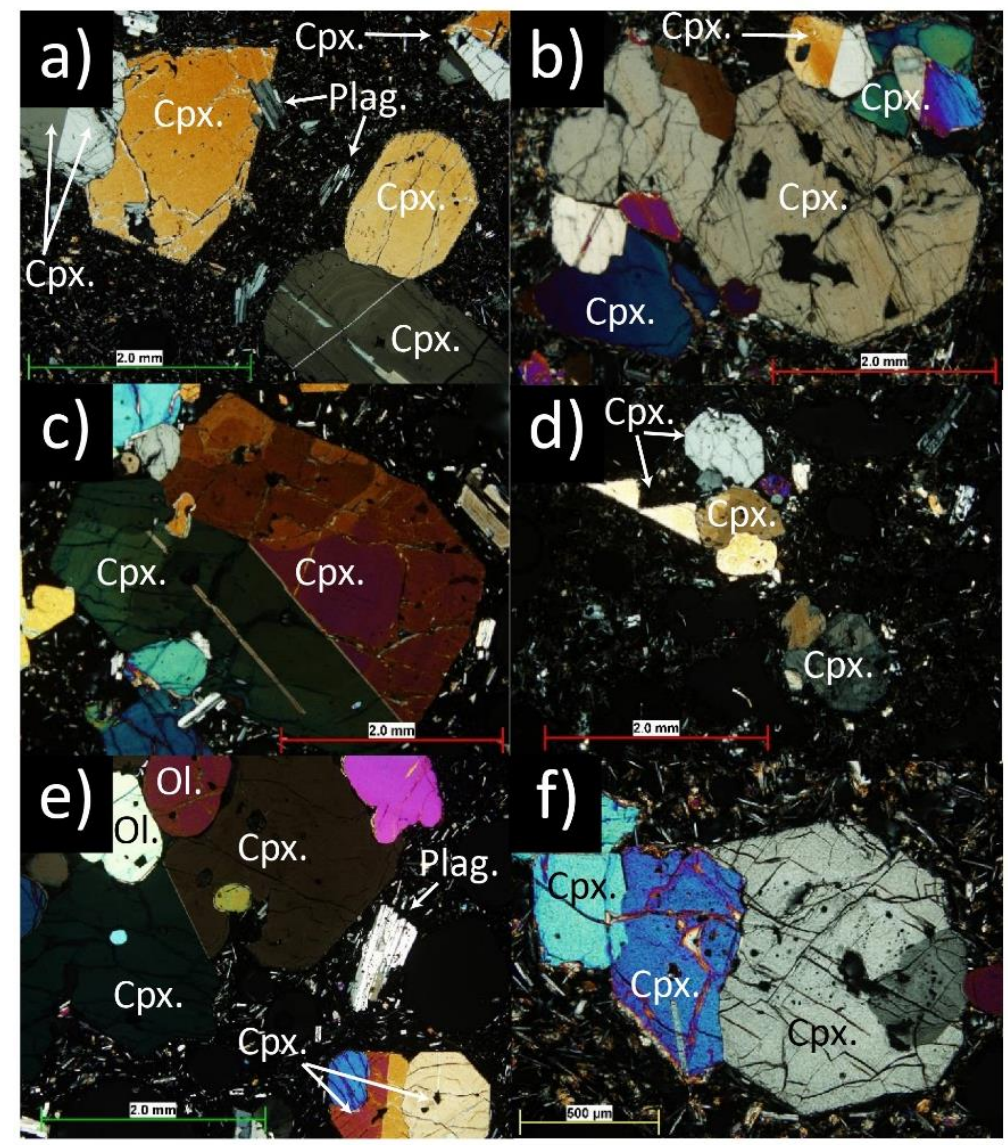

Figure 4.1. Photomicrographs in cross-polarised light of selected clinopyroxene phenocrysts in various samples from Gill Seamount.

The crystal phases shown include clinopyroxene (Cpx.), olivine (Ol.), and plagioclase (Plag.). a) Sample TAN1007-011-01. Note the weak zoning in the phenocryst in the lower right b) Sample TAN1007-012-01. c) Sample TAN1007-011-02. Note the simple twinning in the coarse phenocryst. d) Sample TAN1007-012-07, e) Sample TAN1007-011-11. Not the olivine inclusions and simple twinning in the coarse clinopyroxene phenocryst, and simple twinning in the fine clinopyroxene phenocryst on the lower right. f) Sample TAN1007012-08. Note the altered margin at the lower edge of the middle clinopyroxene phenocryst. 
Plagioclase is present in most of the samples from Gill Seamount investigated in this study (with the exception of sample TAN1007-011-04), and accounts for $\sim 5$ 85 vol. \% of phenocrysts within a given sample (e.g. Figure 4.2). Crystals generally occur as ca. 1 - 2 mm euhedral-subhedral phenocrysts, and commonly display multiple twinning. Glomerocrysts with other plagioclase (and sometimes pyroxene) are common. Micro-phenocrysts (ca. $0.4-0.8 \mathrm{~mm}$ ) are common. Rare embayments are observed along the margins of some crystals. Inclusions of crystalline material (ca. 10 - $30 \mu \mathrm{m})$ are common. Zoning is generally very weak, and usually with crystals displaying thin outer rims, although in some cases optical zoning and/or bands of inclusions are observed. In samples from the dredge of the summit, plagioclase phenocrysts are generally more subequant, and phenocrysts from the flank suite are generally more elongated and tabular.

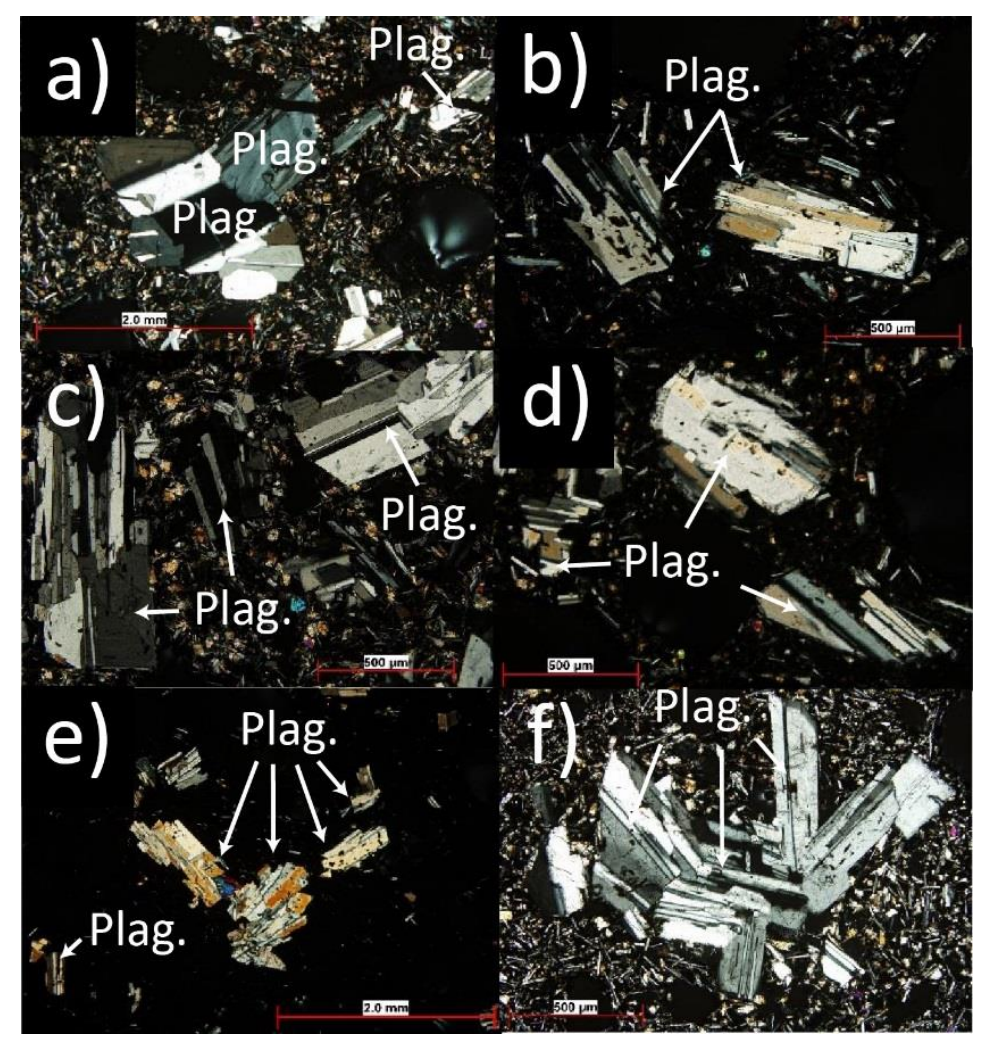

Figure 4.2. Photomicrographs of representative plagioclase phenocrysts in various samples from Gill Seamount, in cross-polarised light.

All the crystal phases shown are plagioclase (Plag.). Note that phenocrysts commonly display a lack of compositional zoning, common twinning, and tabular-crystal habits. a) Sample TAN1007-012-08. Note the optical zoning in the upper right or the coarse plagioclase glomerocryst. b) Sample TAN1007-011-02. Note the tabular crystal habit of the plagioclase phenocrysts. c) TAN1007-012-03. Note the multiple twining in the three labelled plagioclase phenocrysts. d) Sample TAN1007-011-02. Note the thin outer rim and the crystalline inclusions in the upper plagioclase phenocryst on the top. e) TAN1007-011-03. Note the tabular crystal habit in the plagioclase phenocrysts. f) TAN1007-011-09. Not the elongated, tabular crystal habit and simple twinning in the crystals in the coarse plagioclase glomerocryst. 
Olivine phenocryst content shows significant variation between and within each sample suite, ranging from ca. 15 - to 30 vol. $\%$ of phenocrysts in the summit samples, and ca. 10- to 40 vol. \% in the flank samples (e.g. Figure 4.3). Crystals are generally coarse, well-formed euhedral-subhedral, but in rare cases embayed anhedral examples are present. Most phenocrysts are within ca. 4 - $6 \mathrm{~mm}$ in size, but the coarsest crystals range up to ca. 7 - $8 \mathrm{~mm}$ long in some samples, and finer, ca. 1 - $3 \mathrm{~mm}$ long, crystals also occur. Glomerocrysts are sometimes present, typically with olivine and/or pyroxene, and less commonly with plagioclase. Inclusions of spinel (ca. 10 - $30 \mu \mathrm{m}$ ) are common. Melt inclusions are rarely observed. Crystalline material may be present along the margins of internal fractures, as well as inclusions within the host phenocryst.

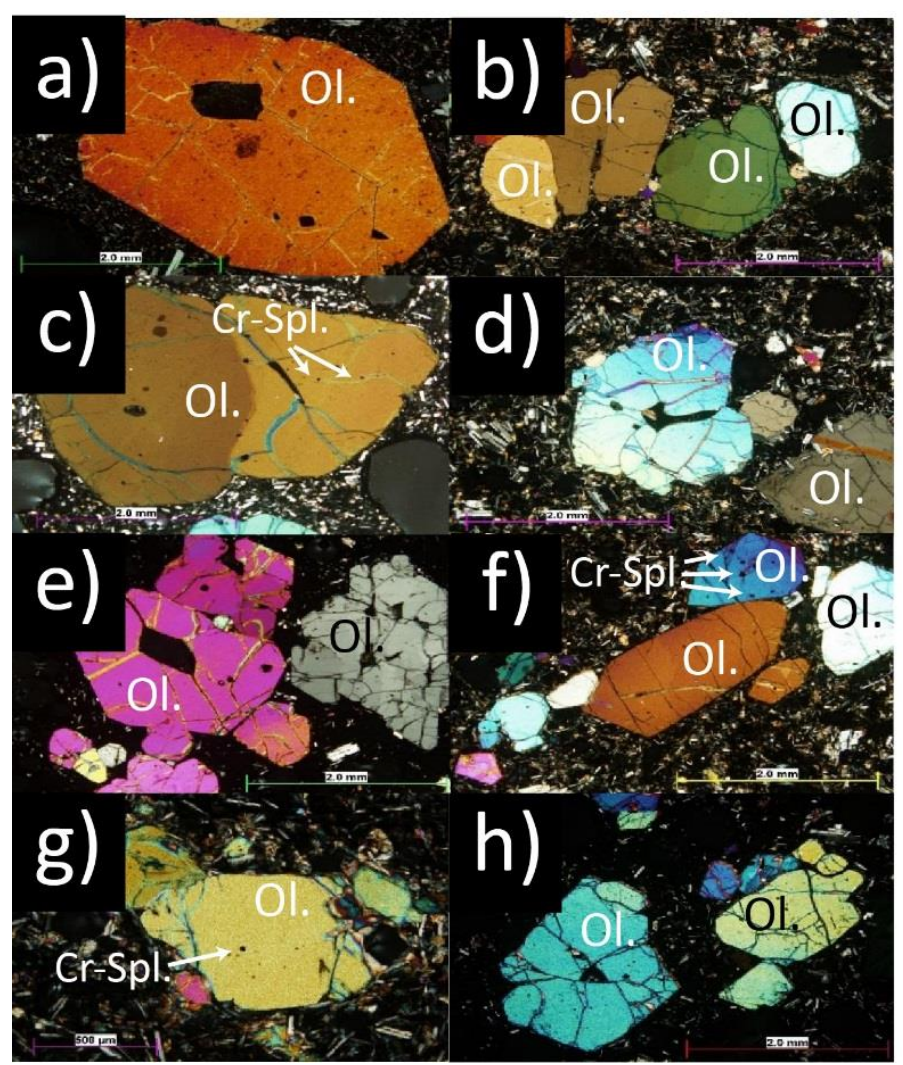

Figure 4.3. Photomicrographs of selected olivine phenocrysts from Gill Seamount, in cross-polarised light.

Phenocrysts either appear coarse-grained and euhedral, or subhedral with altered fractures and inclusions. The crystal phases shown include olivine (Ol.) and Cr-spinel (Cr-Spl.). a) Sample TAN1007-011-01. Note the crystalline inclusion in the coarse euhedral olivine phenocryst. b) Sample TAN1007-012-01. c) Sample TAN1007-011-02. Note the inclusions of Cr-spinel oxides in the right of the coarse euhedral olivine phenocryst. d) Sample TAN1007-012-05. Note the crystalline inclusion within the olivine phenocryst on the left. e) Sample TAN1007-011-03. Note that in the olivine phenocryst on the left, the fine inclusions are Cr-spinel oxides, and the coarser inclusion comprises crystalline material. f) Sample TAN1007-012-01. Note the inclusions of Crspinel oxides in the olivine phenocryst on the upper right. g) Sample TAN1007-011-04. Note the Cr-spinel oxide inclusion in the fine-grained, subhedral olivine phenocryst. h) Sample TAN1007-011-02. 
In general, the framework groundmass of samples from Gill Volcano comprises ca. 75 - 95 vol. \% microcrystalline material, and $<5-25$ vol. \% residual glass, with fine vesicles in between spaces (e.g. Figure 4.4). Minor vesicles are also commonly observed between crystals. Groundmass crystals include acicular plagioclase (ca. 50 - $200 \mu \mathrm{m}$ long, 10 - $30 \mu \mathrm{m}$ wide), sub-equant clinopyroxene (20 $30 \mu \mathrm{m}$ long), and very fine magnetite (ca. <10. $\mu \mathrm{m}$ long). Residual glass is observed more commonly around the margins of vesicles, and in between crystalline material in areas generally finer than $10 \mu \mathrm{m}$. Groundmass glass displays high variation in colour ranging from dark brown to light orange, but is always dark brown in the flank samples.

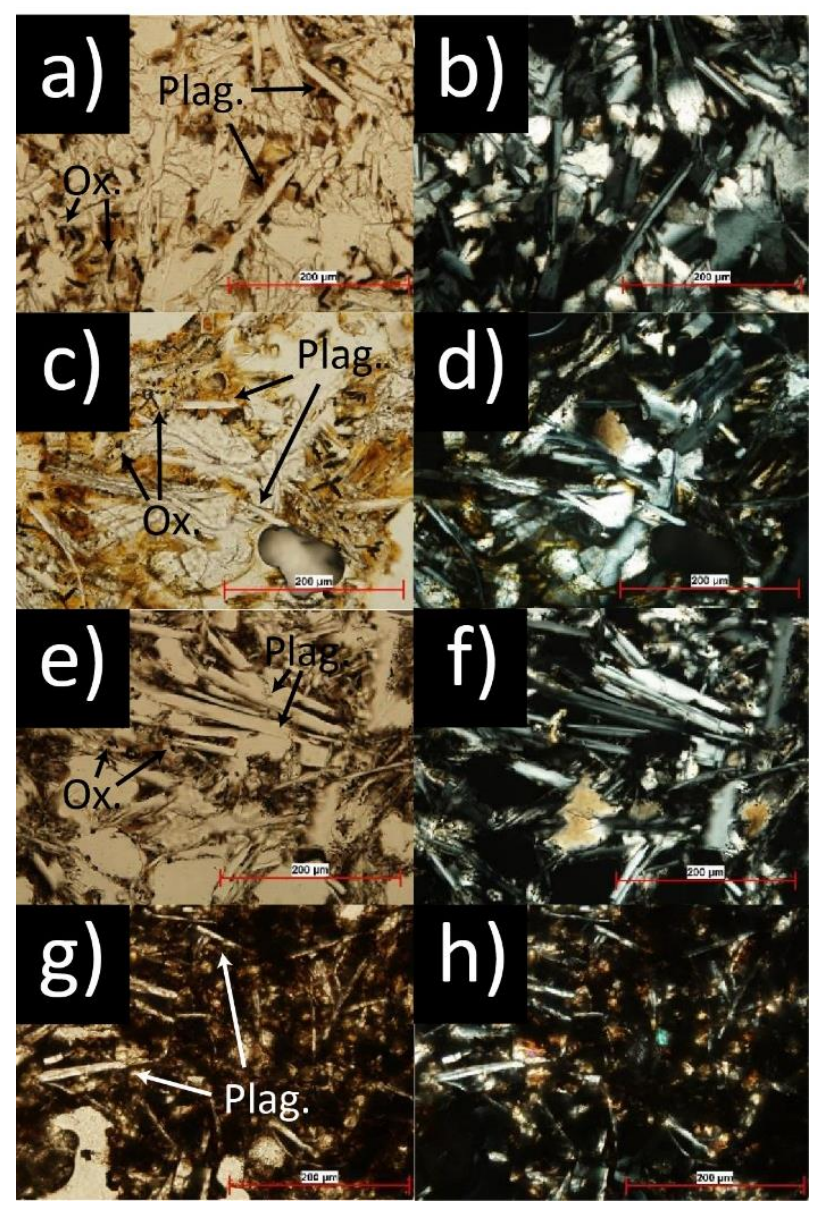

Figure 4.4. Photomicrographs of crystalline groundmass from Gill Seamount.

The crystal phases shown include plagioclase (Plag.) and Fe-Ti oxides (Ox.). Each pair of photomicrographs are associated with the same area of the same sample, in both plane-polarised light and cross-polarised light. Note the variation in glass content and colour. Samples in a) and b) are TAN1007-012-01. Samples in c) and d) are TAN1007-012-05. Samples in e) and f) are TAN1007-011-04. Samples in g) and h) are TAN1007-011-09. 
Vesicles are common in all the samples, and range from 0.5 - $4 \mathrm{~mm}$ long (e.g. Figure 4.5). Sizes are highly variable, and shapes are generally rounded and subequant, but sometimes elongated and/or irregular. Occasionally they occur coalesced as multiple vesicles. In the summit suite, amygdales are common, and may comprise up to 20 vol. \% in some samples, usually in the interior of vesicles and secondary fractures.
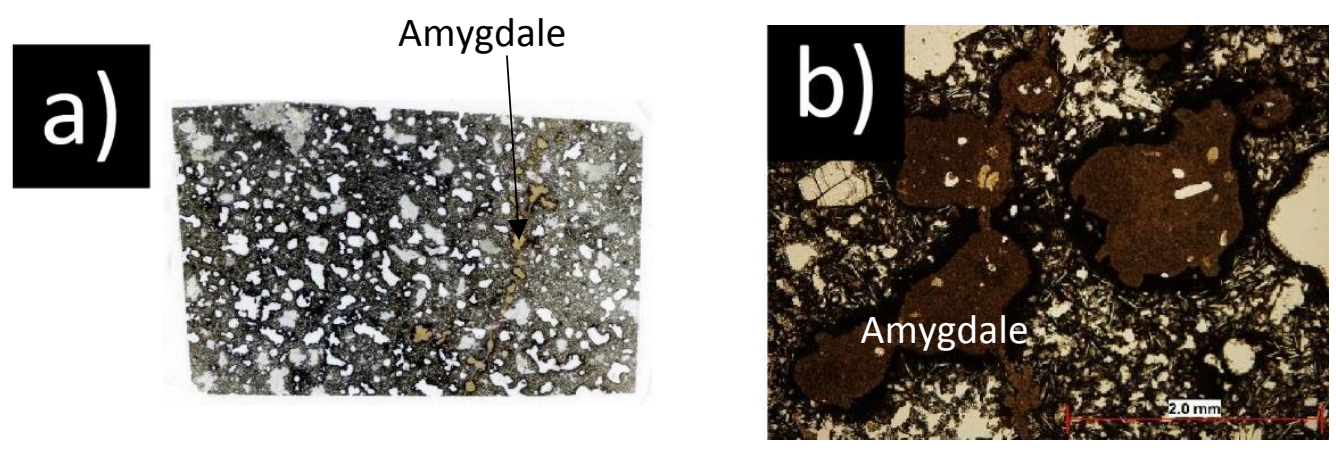

Figure 4.5. Examples of the effect of amygdales on the physical appearance of rock specimens from the TAN1007-012 dredge from Gill Seamount.

a) Thin section image showing the extent of amygdale infiltration in Sample TAN1007-012-08. Note that the image is inverted relative to the photomicrograph in b). b) Photomicrograph of amygdale in Sample TAN1007012-08 in cross-polarised light.

\subsubsection{Petrography of Rapuhia Ridge}

Samples from both lava suites from Rapuhia Ridge have a phenocryst assemblage consisting of olivine \pm orthopyroxene + clinopyroxene. Between the two dredges, samples have significant variation in phenocryst content (ca. 5 - 15 vol. \%), vesicularity (ca. 20 - 40 vol. \%), and groundmass (ca. 50 - 70 vol. \%). Lavas from dredge TAN1007-015 have a more clinopyroxene-rich phenocryst assemblage, and samples from dredge TAN1007-016 suite are more olivine-rich.

Olivine accounts for ca. 20 - 35 vol. \% of the phenocryst assemblage in laveas from TAN1007-015, and ca. 40 - 70 vol. \% in lavas from TAN1007-016 (e.g. Figure 4.6). Olivine phenocrysts typically form individual euhedral- to - subhedral crystals in both sets of samples, with some crystals forming glomercrysts with pyroxene. Most phenocrysts are between, $500-800 \mu \mathrm{m}$ long, but coarser phenocrysts are present that are up to $1-2 \mathrm{~mm}$ in size. Strongly embayed anhedral olivine phenocrysts are more rarely observed. Olivine phenocrysts commonly contain inclusions of 20 - $30 \mu \mathrm{m} \mathrm{Cr}-$ 
spinel oxides, and some contain inclusions of crystalline material and glassy melt inclusions.

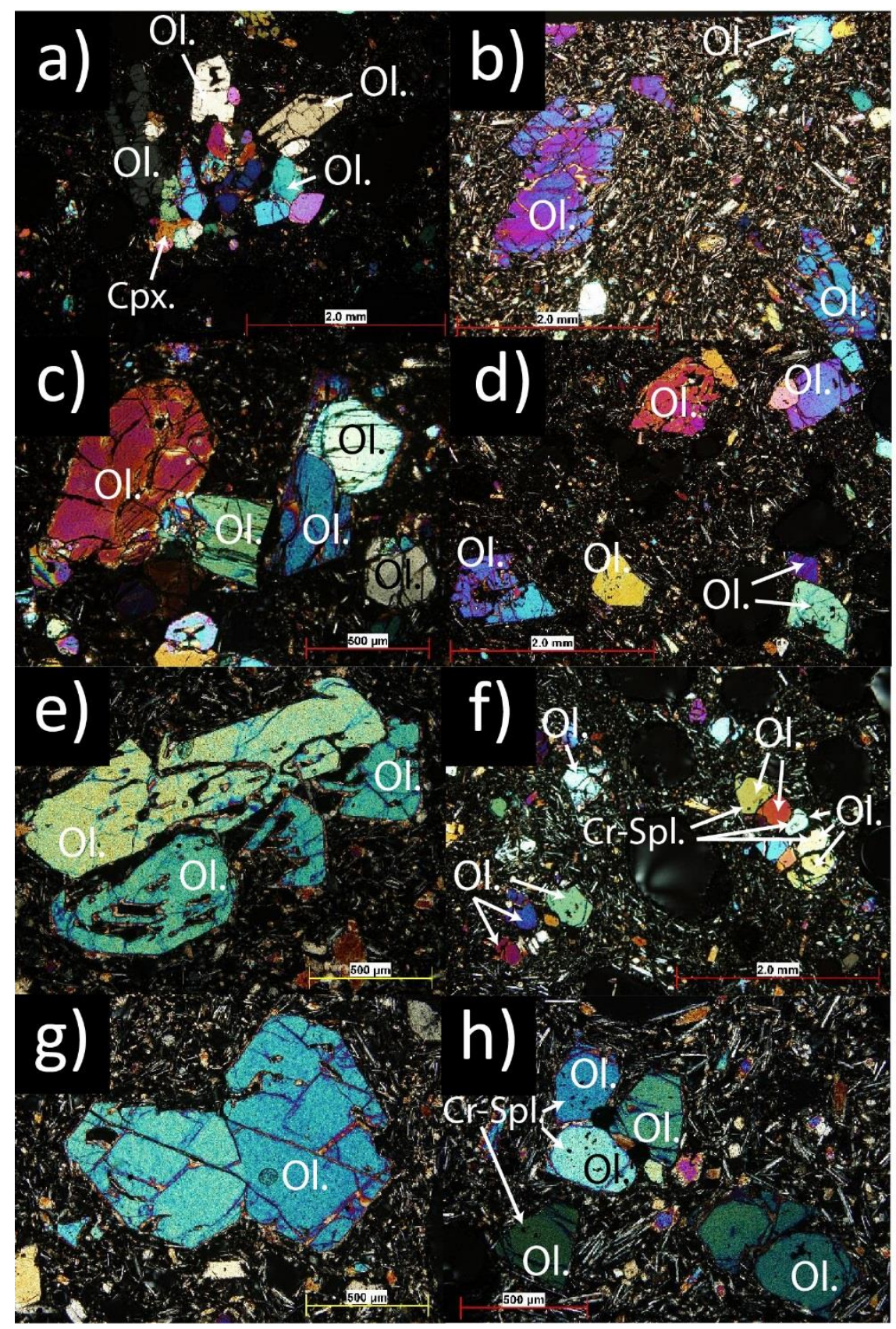

Figure 4.6. Photomicrographs in cross-polarised light of representative olivine phenocrysts in samples from Rapuhia Ridge.

a) Sample TAN1007-015-03. Note the glomerocryst with olivine crystals in association with clinopyroxene crystals. b) Sample TAN1007-016-01. Note the embayed margin in the olivine phenocryst on the lower right. c) Sample TAN1007-015-07. d) Sample TAN1007-016-03. e) Sample TAN1007-015-09. Note the strongly embayed margin in the lower olivine phenocrysts, and the inclusions of crystalline material within the coarse olivine phenocryst. f) Sample TAN1007-016-04. Not the inclusions of Cr-spinel oxides within the olivine phenocrysts on the right. g) Sample TAN1007-015-09. h) Sample TAN1007-016-08. Note the inclusions of Crspinel oxides in the three olivine phenocrysts on the left. The crystal phases shown include olivine (Ol.), clinopyroxene (Cpx.), and $\mathrm{Cr}$-spinel (Cr-Spl.). 
Orthopyroxene is only observed in samples from the TAN1007-016 suite, and generally comprises ca. 5 - 20 vol. \% of a given phenocryst assemblage (e.g. Figure 4.7). Crystals are generally subhedral, ca. 400 - $800 \mu \mathrm{m}$ long, and sometimes contain inclusions of opaques.

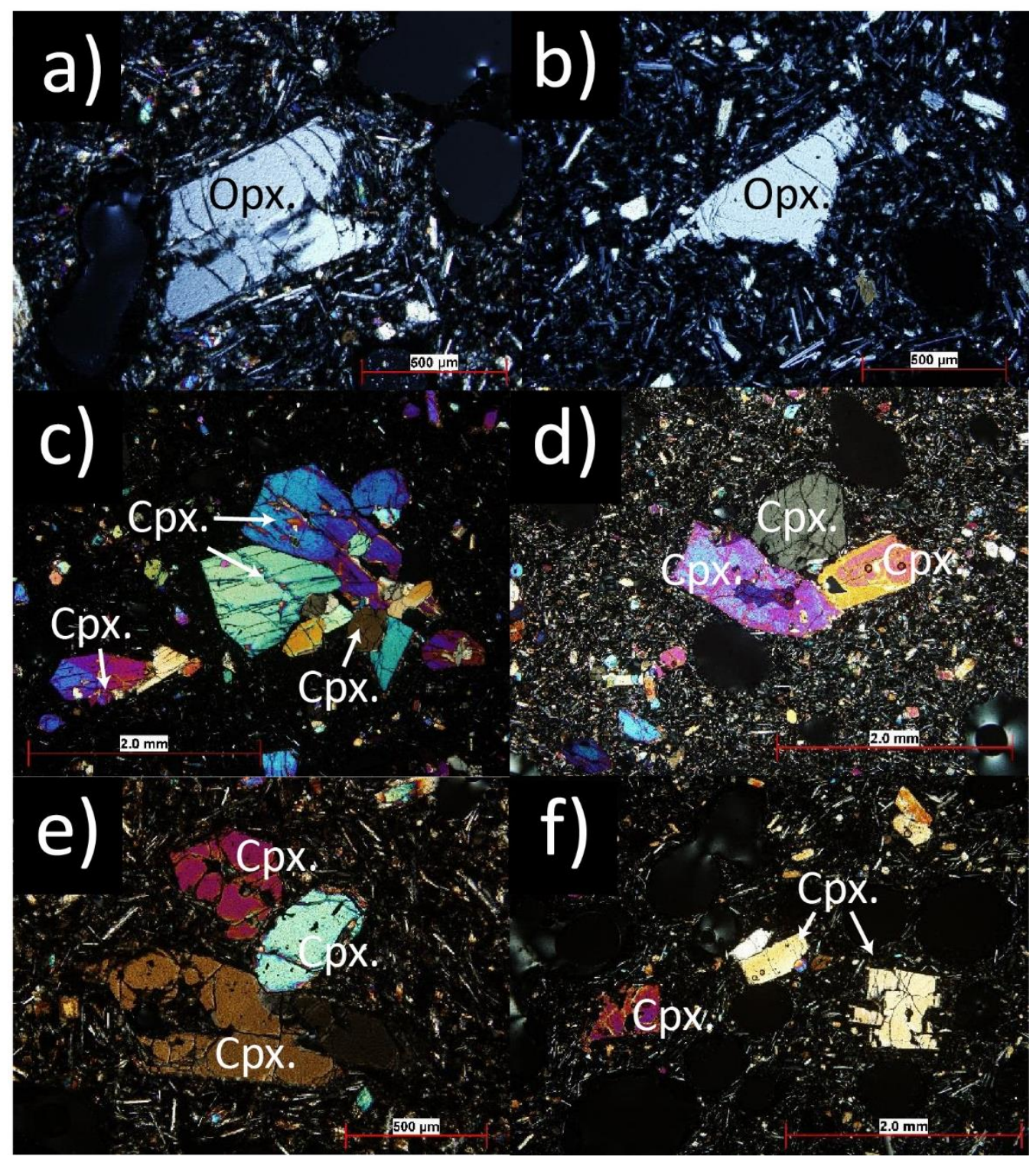

Figure 4.7. Photomicrographs in cross-polarised light of pyroxene phenocrysts from various samples from Rapuhia Ridge.

The crystal phases shown include orthopyroxene (Opx.) and clinopyroxene (Cpx). Orthopyroxene phenocrysts are shown in a) sample TAN1007-016-03, and b) sample TAN1007-016-06. Clinopyroxene phenocrysts are shown in c) sample TAN1007-015-04, d) sample TAN1007-015-09, e) sample TAN1007-016-03, and f) sample TAN1007-016-04. Note the inclusions of crystalline material in the glomerocrysts of clinopyroxene in c) and d). Note the embayed margin in the clinopyroxene phenocryst on the lower left in e). 
Clinopyroxene represents ca. 65 - 80 vol. \% of the phenocryst assemblage in samples from the TAN1007-015 suite, and ca. 35 - 60 vol. \% in lavas from the TAN1007-016 suite (e.g. Figure 4.7). Crystals are generally subhedral and ca. 300 $800 \mu \mathrm{m}$ long, although some are coarser than $1 \mathrm{~mm}$. Embayments are commonly observed. Some phenocrysts display simple twinning. Glomerocrysts with olivine and/or pyroxene are also present. Inclusions of groundmass and crystalline material are common.

Vesicles are abundant in all samples from Rapuhia Ridge. Sizes are highly variable and range from 0.4 - 6 mm long. Most are well-rounded and sub-equant. Coarser vesicles are elongated and are commonly coalesced. Some examples are partially infilled with a dark-brown glassy material.

The framework groundmass of Rapuhia Ridge samples consists of microcrystalline material and residual glass (e.g. Figure 4.8). Microcrystals include acicular plagioclase (ca. 100 - $200 \mu \mathrm{m}$ long, 20 - $30 \mu \mathrm{m}$ wide), sub-equant pyroxene (ca. 20 - $30 \mu \mathrm{m}$ long), fine magnetite (<10. $\mu \mathrm{m}$ long), and residual glass. Microcrystalline material makes up 90-95 vol. \% of the framework groundmass of a given sample, and glass content ranges from $<5-10$ vol. $\%$.

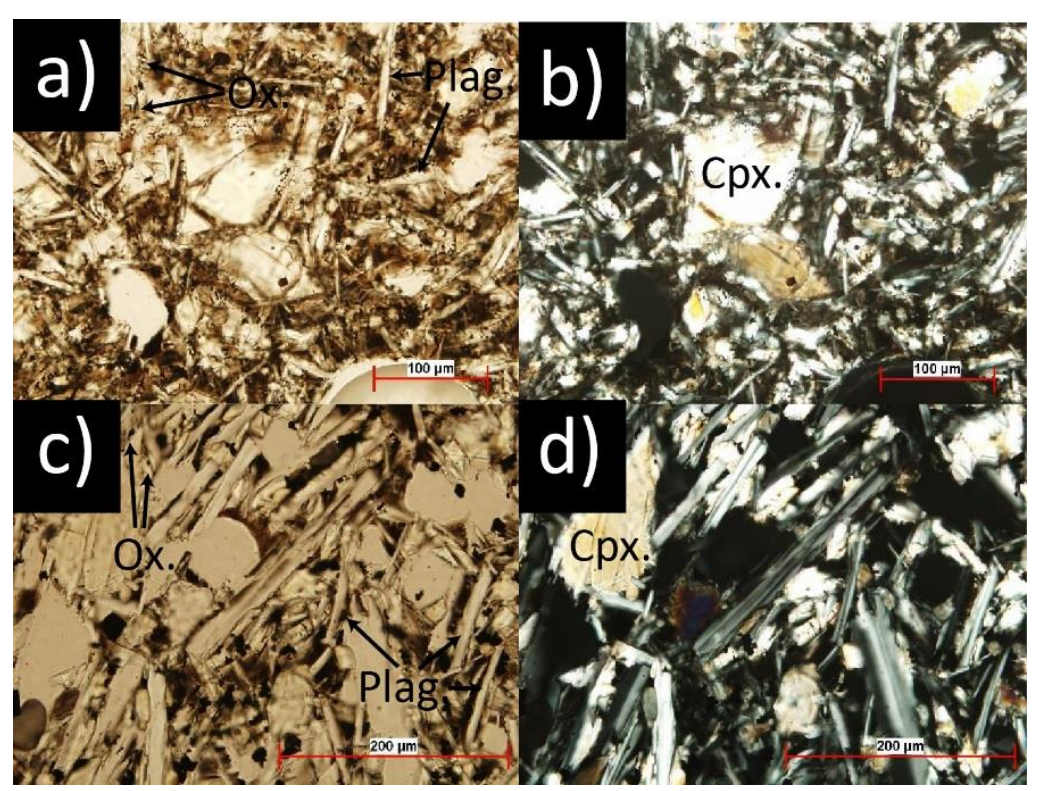

Figure 4.8. Photomicrographs of crystalline groundmass from Rapuhia Ridge samples.

The crystal phases shown include plagioclase (Plag.), clinopyroxene (Cpx.), and Fe-Ti oxides (Ox.). Sample numbers in a) and b) are from TAN1007-015-04, in plane- and cross-polarised light, respectively. Sample numbers in c) and d) are from TAN1007-016-01, in plane- and cross-polarised light, respectively. 


\subsubsection{Petrography of Rapuhia Seamount}

Rapuhia Seamount samples contain a mineral assemblage consisting of plagioclase \pm clinopyroxene \pm amphibole. Accessory phases include ilmenite + magnetite + apatite. Clinopyroxene is only present in samples from the TAN1007-014 suite, and amphibole only occurs in dacites from the TAN0205-101 suite. Lavas from the TAN1007-014 suite are characterised by relatively similar abundances of phenocrysts (15 - 25 vol. \%), groundmass (60 - 70 vol. \%) and vesicularity (10 - 20 vol. \%). By comparison, samples from the TAN0205-101 suite are more phenocrystrich (35 - 40 vol. \%) and vesicle-poor ( $<5$ vol. \%), but contain similar proportions of framework groundmass (60 - 65\%). A single basaltic-andesite was previously analysed and described by Wright et al. (2006), and is not described in this section.

Plagioclase dominates the phenocryst assemblage in Rapuhia Seamount lavas, and comprises ca. 85 - 90 vol. \% of phenocrysts in the TAN1007-014 samples, and ca. 60 - 65 vol. \% of phenocrysts in the TAN0205-101 lavas (e.g. Figure 4.9). Most phenocrysts are euhedral-subhedral, and between 0.5 - $1.5 \mathrm{~mm}$ long, but coarser crystals are up to $3 \mathrm{~mm}$ in size. Simple twinning is common. Most crystals are tabular and sub-equant, and generally display oscillatory zoning. Sieve textures may be present, commonly with inclusions of crystalline material. Phenocrysts from TAN1007-014 lavas may also occur as glomerocrysts with clinopyroxene and Fe-Ti oxides. Plagioclase crystals from the TAN0205-101 lavas commonly display either normal or reverse zoning and some contain melt inclusions that are ca. $50-100 \mu \mathrm{m}$ long. Inclusions of Fe-Ti oxides and apatite are common in phenocrysts from both lava suites.

Amphibole accounts for ca. 25 - 30 vol. $\%$ of phenocrysts in lavas from the TAN0205-101 suite (e.g. Figure 4.10). Crystals are generally euhedral-subhedral. Sizes are highly variable with micro-phenocrysts $<0.3 \mathrm{~mm}$, and coarse phenocrysts that are up to $3 \mathrm{~mm}$ long. Embayments are present in some phenocrysts. Some amphibole crystals occur in glomerocrysts with plagioclase and Fe-Ti oxides. Inclusions of crystalline material and Fe-Ti oxides are common. Some phenocrysts contain 50 - $100 \mu \mathrm{m}$-sized glassy melt inclusions. 


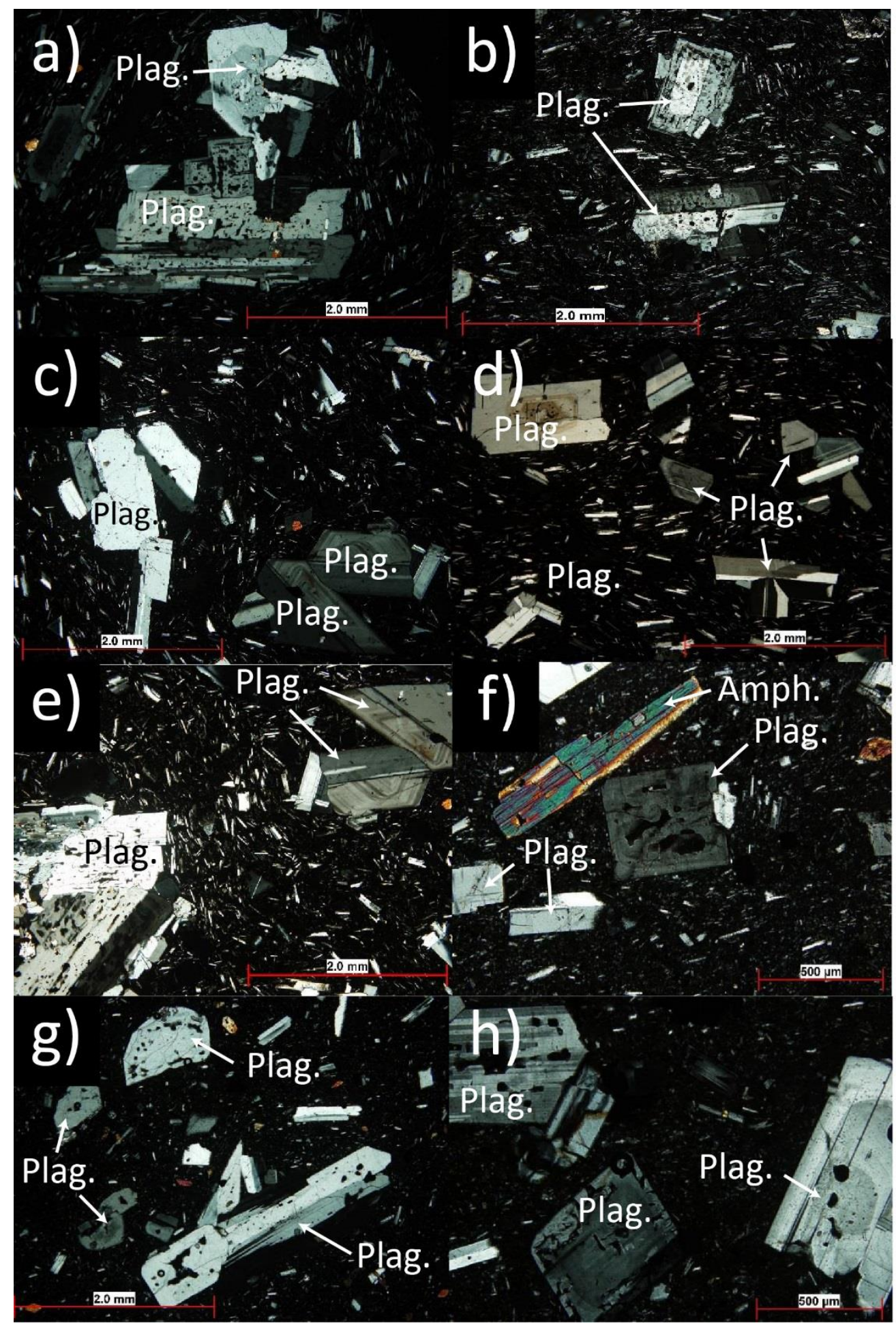

Figure 4.9. Photomicrographs in cross-polarised light of plagioclase phenocrysts in various samples from Rapuhia Seamount.

The crystal phases shown include plagioclase (Plag.) and amphibole (Amph.). a) Sample TAN1007-014-02. Note the abundant melt inclusions in the plagioclase phenocryst on the lower centre. b) Sample TAN1007014-03. Note the optical zoning in the lower plagioclase phenocryst, the crystalline inclusions within both phenocrysts, and the trachytic textured-groundmass plagioclase. c) Sample TAN1007-014-04. Note the oscillatory zoning in the plagioclase phenocryst on the lower right. d) Sample TAN1007-014-05. Note the sieve texture within the tabular plagioclase phenocrysts on the upper left. e) TAN1007-014-04. Note the oscillatory zoning in the plagioclase phenocrysts on the upper right. f) Sample TAN0205-101-03. Note the $200 \mu \mathrm{m}$-long melt inclusions within the tabular-shaped plagioclase phenocrysts in the centre. g) Sample TAN0205-101-03. h) Sample TAN0205-101-03. 


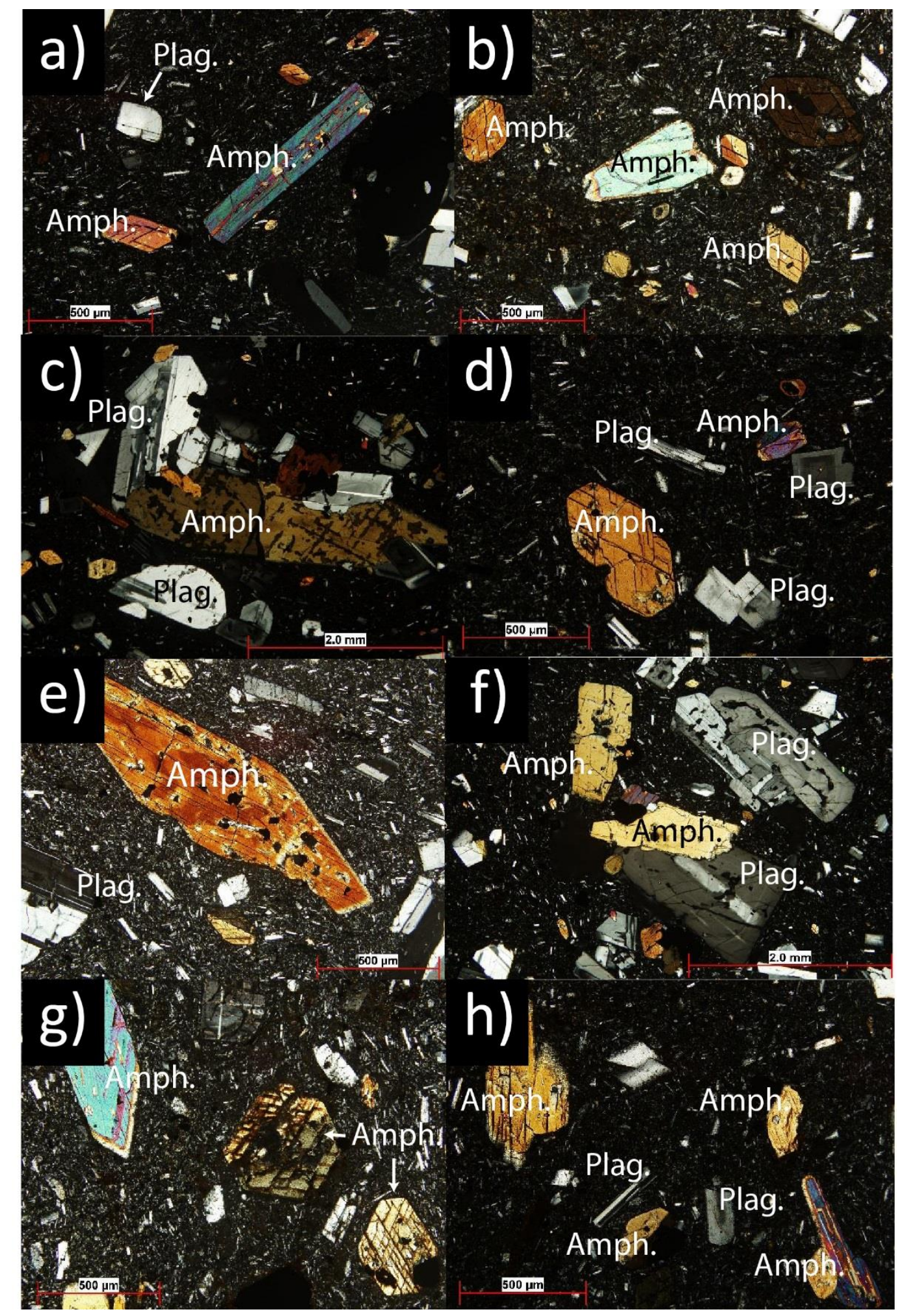

Figure 4.10. Photomicrographs of amphibole phenocrysts in cross-polarised light in TAN0205-101 lavas from Rapuhia Seamount.

The crystal phases shown include amphibole (Amph.) and plagioclase (Plag.). Samples shown are a) TAN0205101-02, b) TAN0205-101-02, c) TAN0205-101-02, d) TAN0205-101-02, e) TAN0205-101-03, f) TAN0205-10103, g) TAN0205-101-03, and h) TAN0205-101-03. 
Clinopyroxene occurs as subordinate phenocrysts in TAN1007-14 lavas (1015 vol. \%), (e.g. Figure 4.11). Crystals are generally subhedral and $0.5-1.5 \mathrm{~mm}$ long. Alteration is present along the margins of some phenocrysts. Most crystals contain inclusions of crystalline material and Fe-Ti oxides.

Fe-Ti oxides include ilmenite and magnetite, and are generally $<100 \mu \mathrm{m}$ long (e.g. Figure 4.11). Many co-exist as a pair, or are in contact with plagioclase and clinopyroxene phenocrysts.

Apatite occurs as single crystals, generally ca. $<10$ - $30 \mu \mathrm{m}$ long, and is commonly found associated with Fe-Ti oxides and as inclusions in plagioclase (e.g. Figure 4.11).

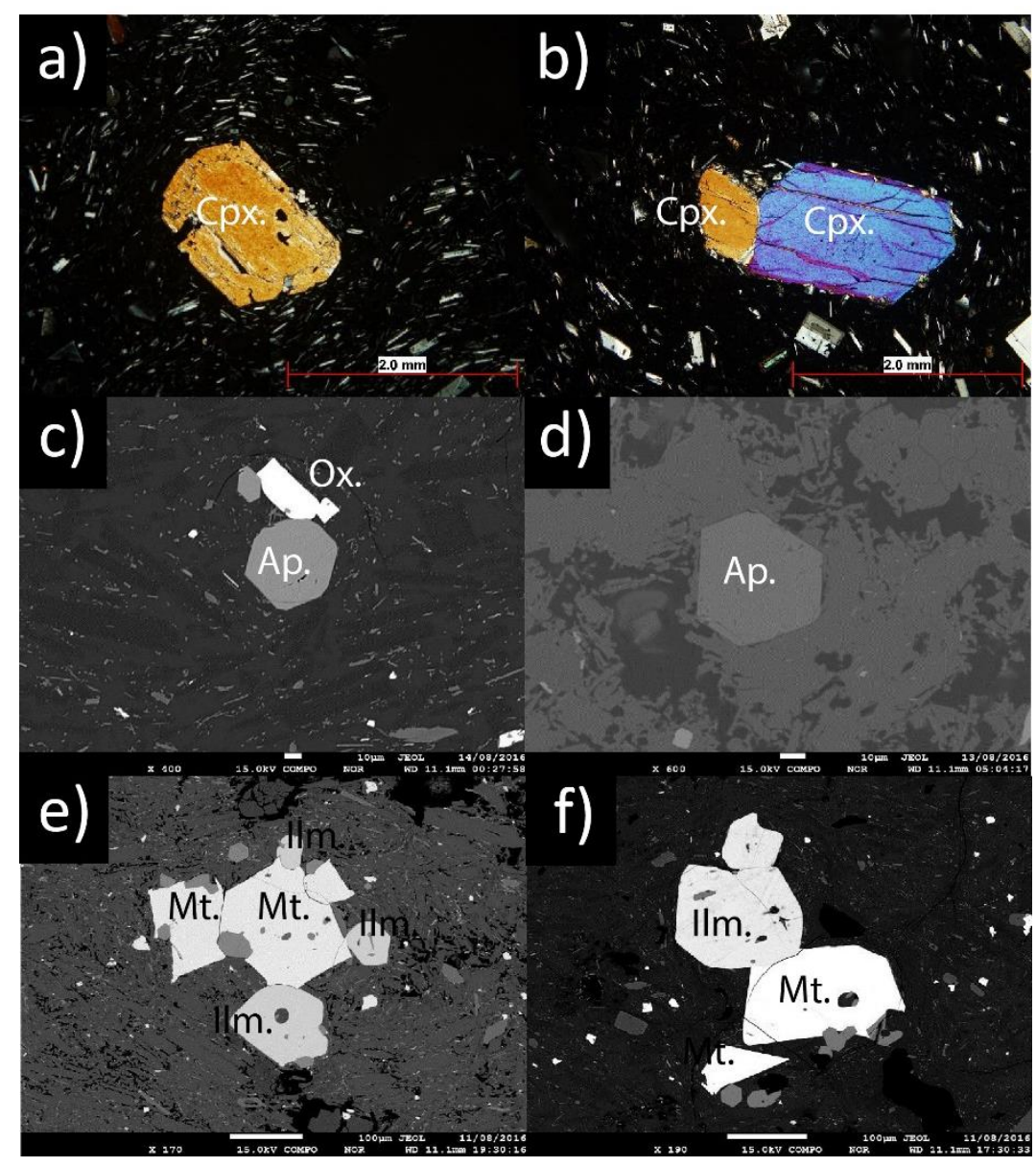

Figure 4.11. Examples of clinopyroxene, apatite, and Fe-Ti oxides in various samples from Rapuhia Seamount.

The crystal phases shown are clinopyroxene (Cpx.), apatite (Ap.), ilmenite (Ilm.), and magnetite (Mt.). a) and b) are photomicrographs of clinopyroxene in cross-polarised light from samples TAN1007-014-02 and TAN1007-014-06. Note the fine corona rim in the clinopyroxene phenocrysts in b). c) and d) are BSE images of apatite from samples TAN1007-014-03 and TAN1007-014-05. e) and f) are BSE images of ilmenite and magnetite from samples TAN1007-014-03 and TAN1007-014-05. 
Xenoliths of multigranular aggregates of weathered plagioclase and clinopyroxene are also present, and comprise <1 vol. \%. (e.g. Figure 4.12).

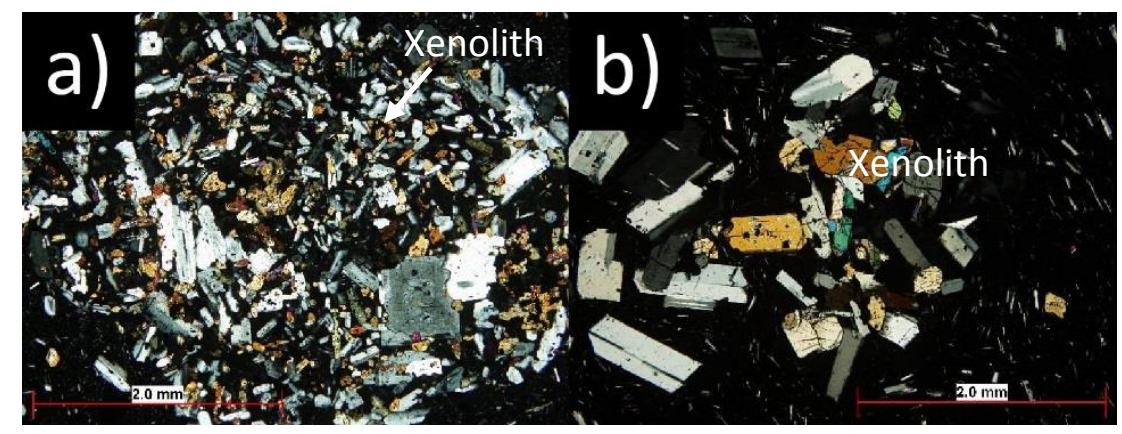

Figure 4.12. Photomicrographs of xenolith fragments in two samples from Rapuhia Seamount, in crosspolarised light.

Samples are a) TAN1007-101-02 and b) TAN1007-014-08.

The framework groundmass of Rapuhia lavas consists of ca. 65 - 75 vol. \% microcrystalline groundmass and ca. 25 - 35 vol. \% residual glass. Microcrystalline phases include bladed plagioclase (ca. 95 vol. \%), and Fe-Ti oxides and apatite (ca. $<5$ vol. \%). Lavas from sample TAN1007-014 are characterised by a trachytic texture. Groundmass plagioclase crystals show highly variable sizes, and range from $<5-20$ $\mu \mathrm{m}$ wide, and $<50$ - $150 \mu \mathrm{m}$ long.

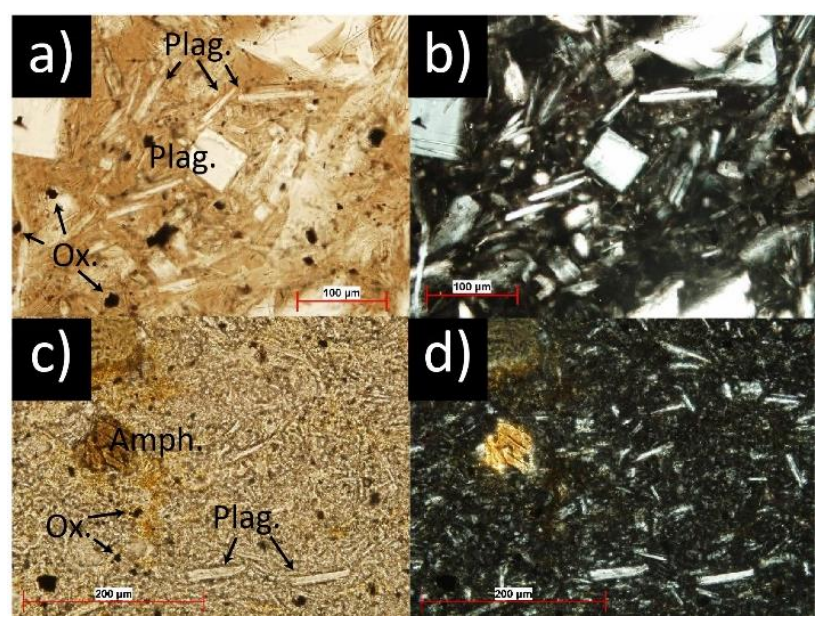

Figure 4.13. Photomicrographs of crystalline groundmass from Rapuhia Seamount.

The crystal phases shown include plagioclase (Plag.), amphibole (Amph.), and Fe-Ti oxides (Ox.). Note the trachytic texture, Fe-Ti oxides, and lath-shaped plagioclase crystals. a) and b) show the same area of sample TAN1007-014-01 in plane- and cross-polarised light. c) and d) show the same area of sample TAN0205-101-02 in plane- and cross-polarised light. 


\subsubsection{Petrography of Giljanes Seamount}

Sample TAN0205-100-03 of Giljanes Seamount is characterised by ca. 65 vol. $\%$ phenocrysts, ca. 30 vol. \% groundmass, and <5 vol. \% vesicles. Phenocrysts comprise ca. 65 vol. \% plagioclase, 35 vol. \% clinopyroxene, and <5 vol. \% amphibole. Accessory phases include Fe-Ti oxides and apatite. These general petrological features are similar to those of sample TAN0205-100-02, a basalticandesite described in Wright et al. (2006).

Plagioclase phenocrysts have highly variable sizes, and range from $<0.5-4$ $\mathrm{mm}$ in length. Micro-phenocrysts $(<0.3 \mathrm{~mm})$ are common. Crystals are generally euhedral-subhedral, and range from being lath-shaped to tabular-shaped, but anhedral crystals are also present. Plagioclase phenocrysts are commonly present as individual crystals, but may be present as glomerocrysts $(>2 \mathrm{~mm})$ with other plagioclase \pm pyroxene crystals. Multiple twinning is present in some crystals. Oscillatory zoning is common. Many crystals contain inclusions of crystalline material and Fe-Ti oxides. Melt inclusions are common within the cores of crystals, or aligned in bands. Coarse spongy interiors are common within sieve textured-crystals.

Pyroxene phenocrysts are finer than plagioclase (sizes range from $0.5-0.6$ $\mathrm{mm}$ ), and are generally present as euhedral-subhedral sub-equant crystals, but are sometimes elongated. Crystals are generally present as a single phase, but also appear as microphenocrysts and in association with plagioclase in glomerocrysts. Simple twinning is observed in some crystals. Most crystals contain internal fractures, and inclusions of crystalline material and/or Fe-Ti oxides. Alteration is observed along margins and within internal fractures of some phenocrysts.

Amphibole is present as a minor phenocryst component, and crystals are ca. 400 - $500 \mu \mathrm{m}$ long. Only three amphibole phenocrysts were observed in sample TAN0205-100-03. Altered margins occur along the rims and all phenocrysts contain internal fractures and inclusions of crystalline material.

Fe-Ti oxides include ilmenite and magnetite. They are present as a minor phase, generally $<100 \mu \mathrm{m}$. They are commonly associated in pairs together, or as single crystals. They may share a common boundary with a plagioclase phenocryst. 


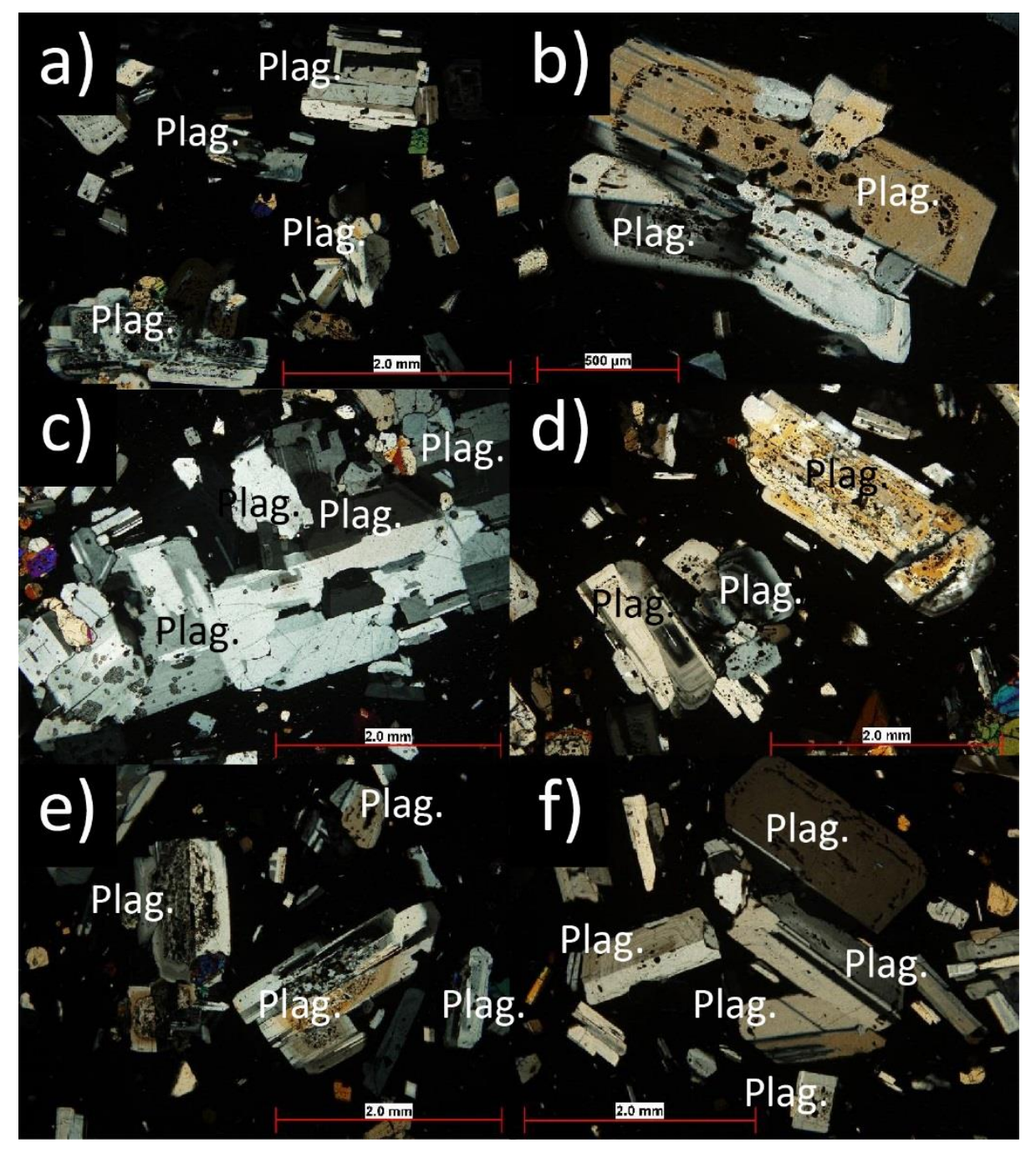

Figure 4.14. Photomicrographs of plagioclase phenocrysts from sample TAN0205-100-03, from Giljanes Seamount.

All the crystal phases shown are plagioclase (Plag.). Note the abundant melt inclusions in plagioclase phenocrysts in b), d), and e), and oscillatory zoning in plagioclase phenocrysts in d) and f).

Apatite occurs as single crystals (ca. $<10-30 \mu \mathrm{m}$ ), with some sharing a common boundary with a Fe-Ti oxide or plagioclase crystal. They also occur as inclusions within plagioclase.

Xenoliths of multigranular aggregates of weathered plagioclase and clinopyroxene are also present, and comprise $<1$ vol. $\%$. 


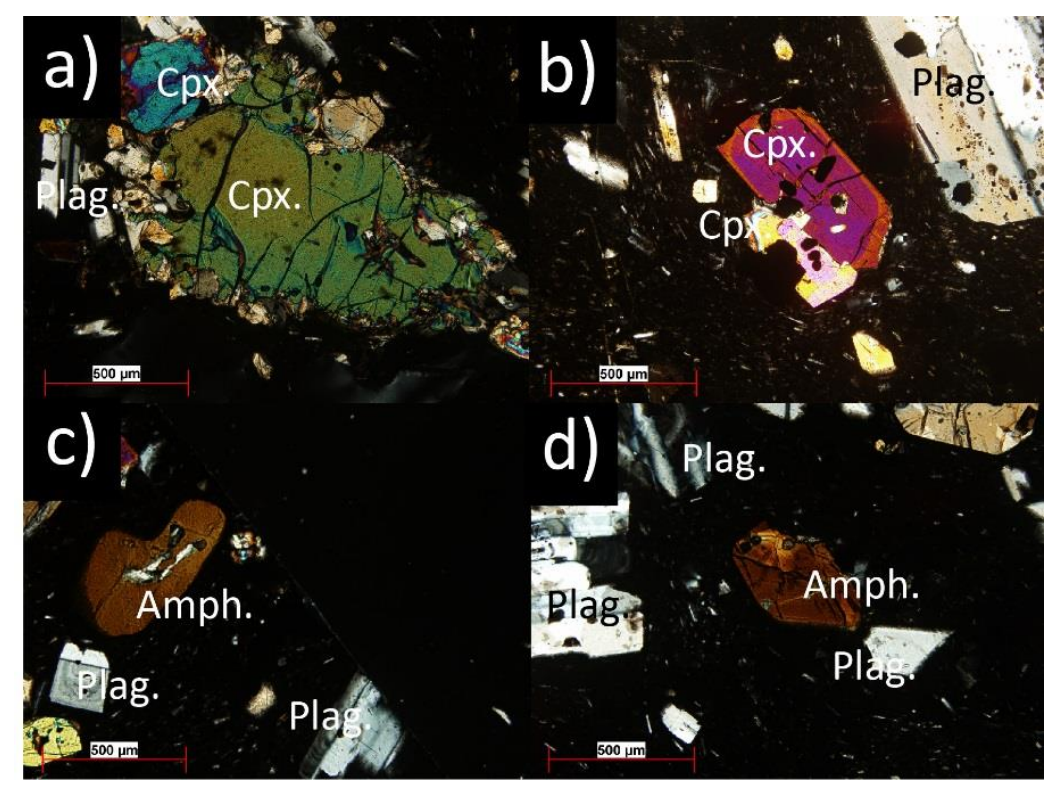

Figure 4.15. Photomicrographs of clinopyroxene and amphibole phenocrysts from sample TAN0205-100-03 from Giljanes Seamount, in cross-polarised light.

The crystal phases shown include plagioclase (Plag.), clinopyroxene (Cpx.), and amphibole (Ampb.). Clinopyroxene phenocrysts are shown in a) and b). Amphibole phenocrysts are shown in c) and d). Note the altered margins in the clinopyroxene phenocrysts in a), and crystalline inclusions in the amphibole phenocryst in c).

The framework groundmass for sample TAN1007-100-03 consists of 65 vol. $\%$ crystalline material, and ca. 35 vol. \% residual glass. Groundmass crystalline phases consist of ca. 95 vol. \% plagioclase, and <5 vol. \% Fe-Ti oxides and apatite. Plagioclase micro-crystals range from being acicular-shaped to tabular-shaped. Sizes range from $<20-80 \mu \mathrm{m}$ long, and $<5-20 \mu \mathrm{m}$ wide.

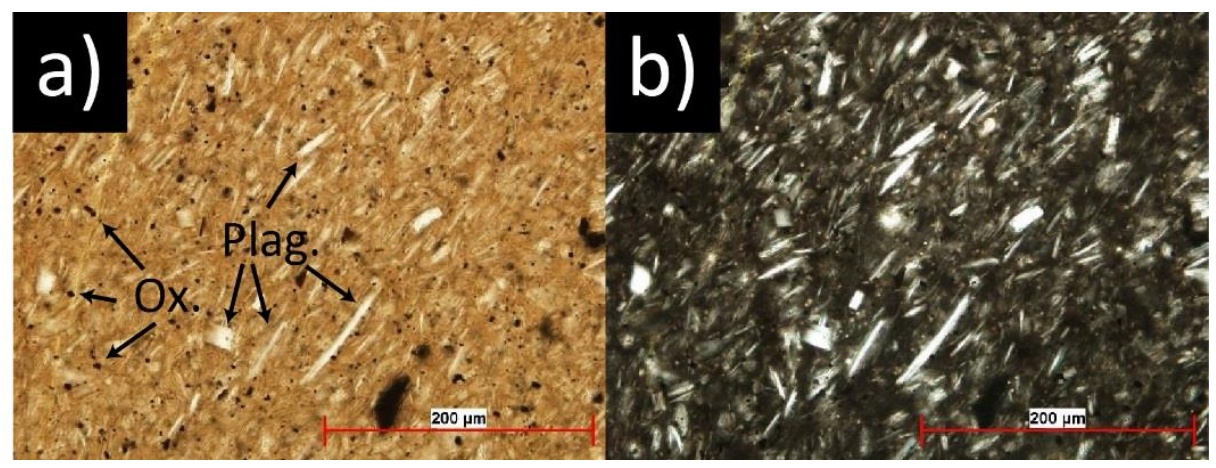

Figure 4.16. Photomicrographs of framework groundmass of sample TAN0205-100-03 from Giljanes Seamount, showing the same area, in a) plane-polarised light, and b) in cross-polarised light.

The crystal phases shown include plagioclase (Plag.) and Fe-Ti oxides (Ox.). 


\subsection{Whole Rock Geochemistry}

Using the major element classification scheme outlined in Le Bas et al. (1986), bulk rock compositions of the back-arc volcano lavas range from basalt to dacite in composition (i.e. ca. 45 - 68 wt \% $\mathrm{SiO}_{2}$ ) (Figure 4.17). Nearly all samples from Gill Summit and Rapuhia Ridge are basaltic in compoistion $\left(<52 \mathrm{wt} \% \mathrm{SiO}_{2}\right)$, with a single sample from Gill Summit plotting in the basaltic-andesitic field in (Figure 4.17). The majority of lavas from Rapuhia Summit and Yokosuka Summit have dacitic compositions, but also include an andesitic sample from Yokosuka, and a basalticandesite from Rapuhia. Both samples from Giljanes Summit have bulk-rock andesitic compositions (Figure 4.17).

$\mathrm{FeO} * \mathrm{MgO}$ contents range from ca. $0.8-1.7$ wt \% in mafic lavas, and ca. 2.2 - 3.9 wt $\%$ in andesitic and dacitic lavas (Figure 4.17). $\mathrm{K}_{2} \mathrm{O}$ contents range from ca. 0.3 - 1 wt $\%$ in the mafic samples, and from ca. $1.5-2.1 \mathrm{wt} \%$ in the dacitic and andesitic samples (Figure 4.18). Nearly all the lavas plot near the boundary separating the low-K and medium-K fields of Gill (1981) (Figure 4.18).

With the exception of the lava suite from the summit of Gill Seamount, nearly all whole rock analyses appear to plot on single trends for a given trace element and oxide. For example, $\mathrm{Ni}$ and $\mathrm{Cr}$ increase with increasing $\mathrm{MgO}$, and decrease with decreasing $\mathrm{SiO}_{2}$ (Figure 4.18). Analyses also show strong negative correlations between incompatible trace elements, such as $\mathrm{Zr}$ and $\mathrm{Hf}$, and increasing $\mathrm{MgO}$ (Figure 4.18).

When compared with N-MORB, all samples investigated in this study are characterised by greater concentrations of fluid-mobile large ion lithophile elements (LILE) (e.g. K, Cs, Rb, Ba, U, K, Pb, Sr) and light rare earth elements (LREE) (Figures 4.19 - 4.22). All whole rock analyses are also characterised by lower concentrations of high field strength elements (HFSE) (e.g. Nb, Ta, Ti) and heavy rare earth elements (HREE) when compared with LILE and REE values (Figures 4.19 - 4.22). Such trace element patterns are typical of subduction-modified arc magmas (e.g. Pearce and Peate, 1995). 
a)

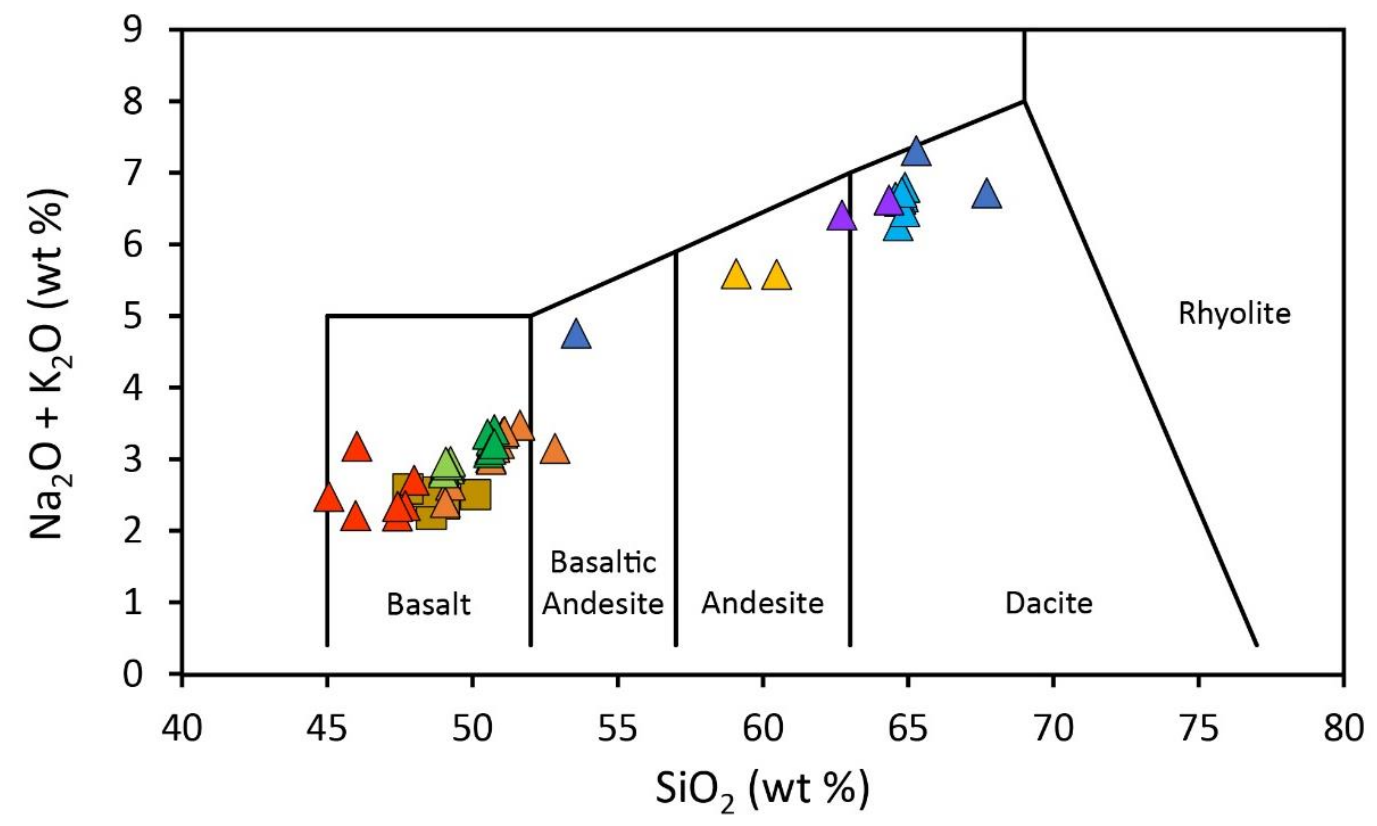

b)

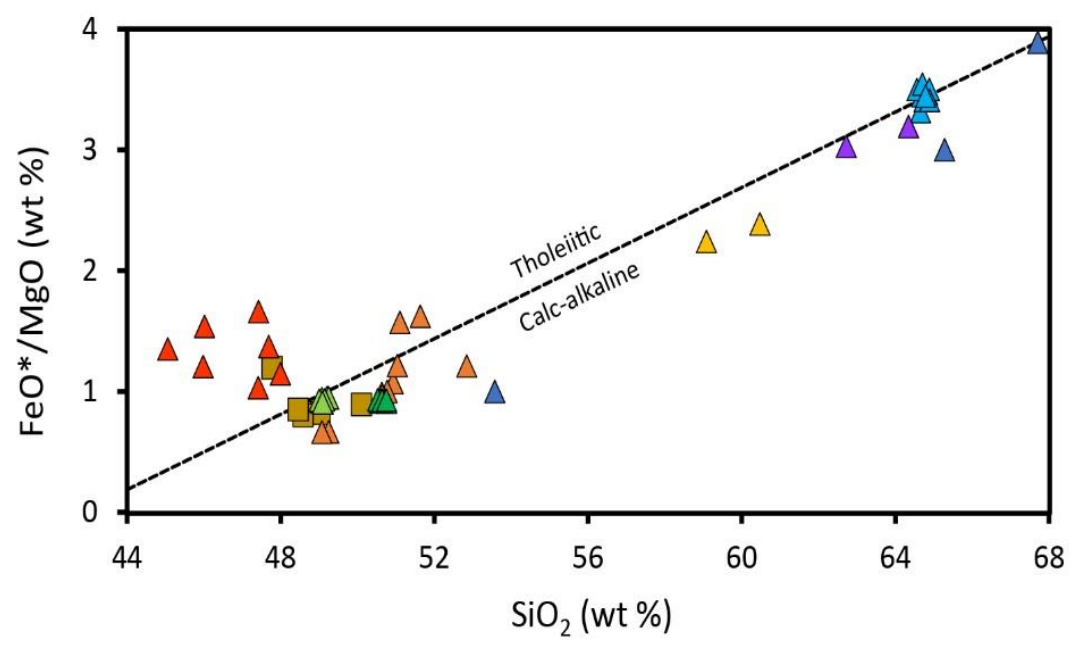

$\square$ Western Havre Trough Back-arc Basins $\triangle$ Gill Seamount (TAN1007-011)

$\Delta$ Gill Seamount (TAN1007-012)

$\Delta$ Rapuhia Ridge (TAN1007-015)

$\triangle$ Rapuhia Ridge (TAN1007-016)

$\triangle$ Rapuhia Seamount (TAN1007-014)

$\Delta$ Rapuhia Seamount (TAN0205-101)

$\Delta$ Yokosuka Seamount (TAN0205-102)

$\triangle$ Giljanes Seamount (TAN0205-100)

Figure 4.17. Plots showing whole rock wt $\%$ of a) total alkali, b) $\mathrm{FeO} / \mathrm{MgO}$, and c) $\mathrm{K}_{2} \mathrm{O}$ against $\mathrm{SiO}_{2}$, for backarc lavas investigated in this study.

The TAS plot comes from Le Bas et al. (1986). Tholeiitic-calc-alkaline boundary for $\mathrm{FeO} * / \mathrm{MgO}$ is from Miyashiro (1974). 
a)

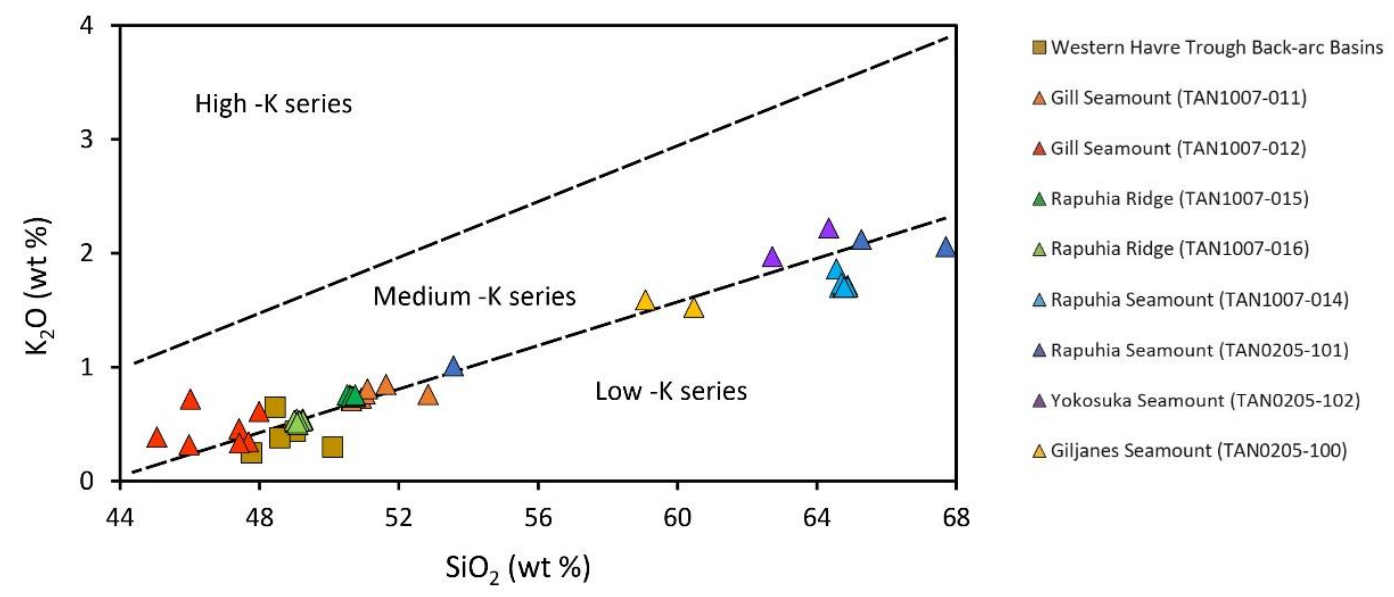

b)

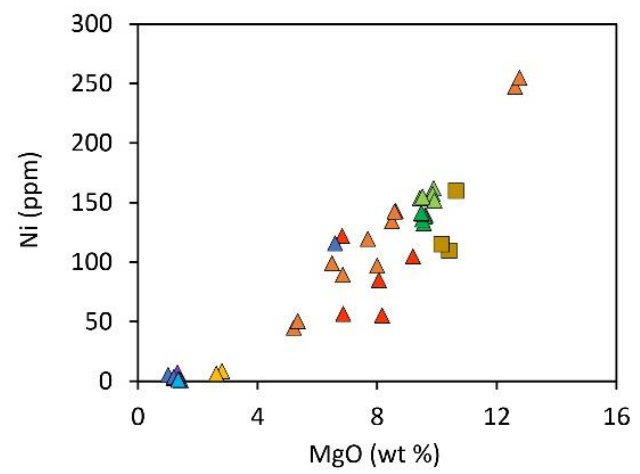

d)

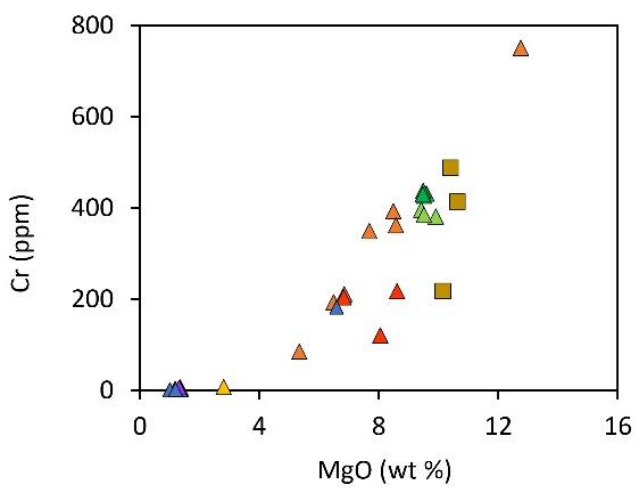

c)

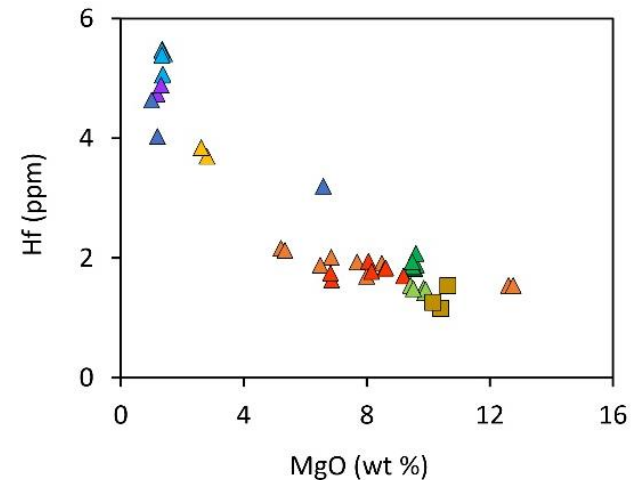

e)

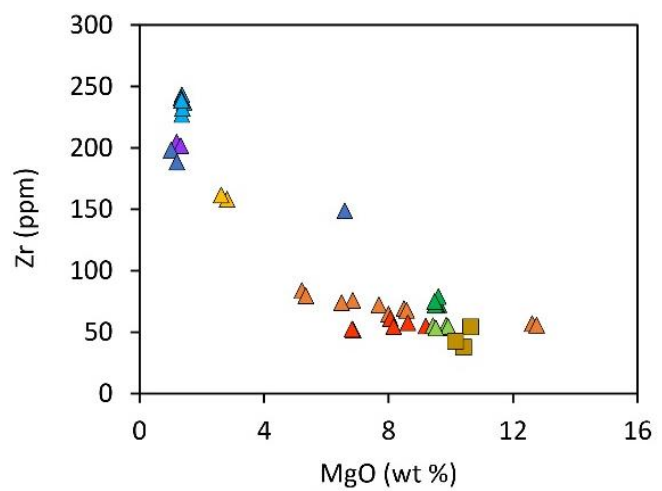

Figure 4.18. Plots of a) $\mathrm{K}_{2} \mathrm{O}$ versus $\mathrm{SiO}_{2}$. Plots b) to e) are of $\mathrm{Ni}, \mathrm{Hf}, \mathrm{Cr}$, and $\mathrm{Zr}$, plotted against $\mathrm{MgO}$.

Boundaries distinguishing between low $-\mathrm{K}$, medium $-\mathrm{K}$ and high $-\mathrm{K}$ are from Gill (1981). Symbols are the same for all plots. 


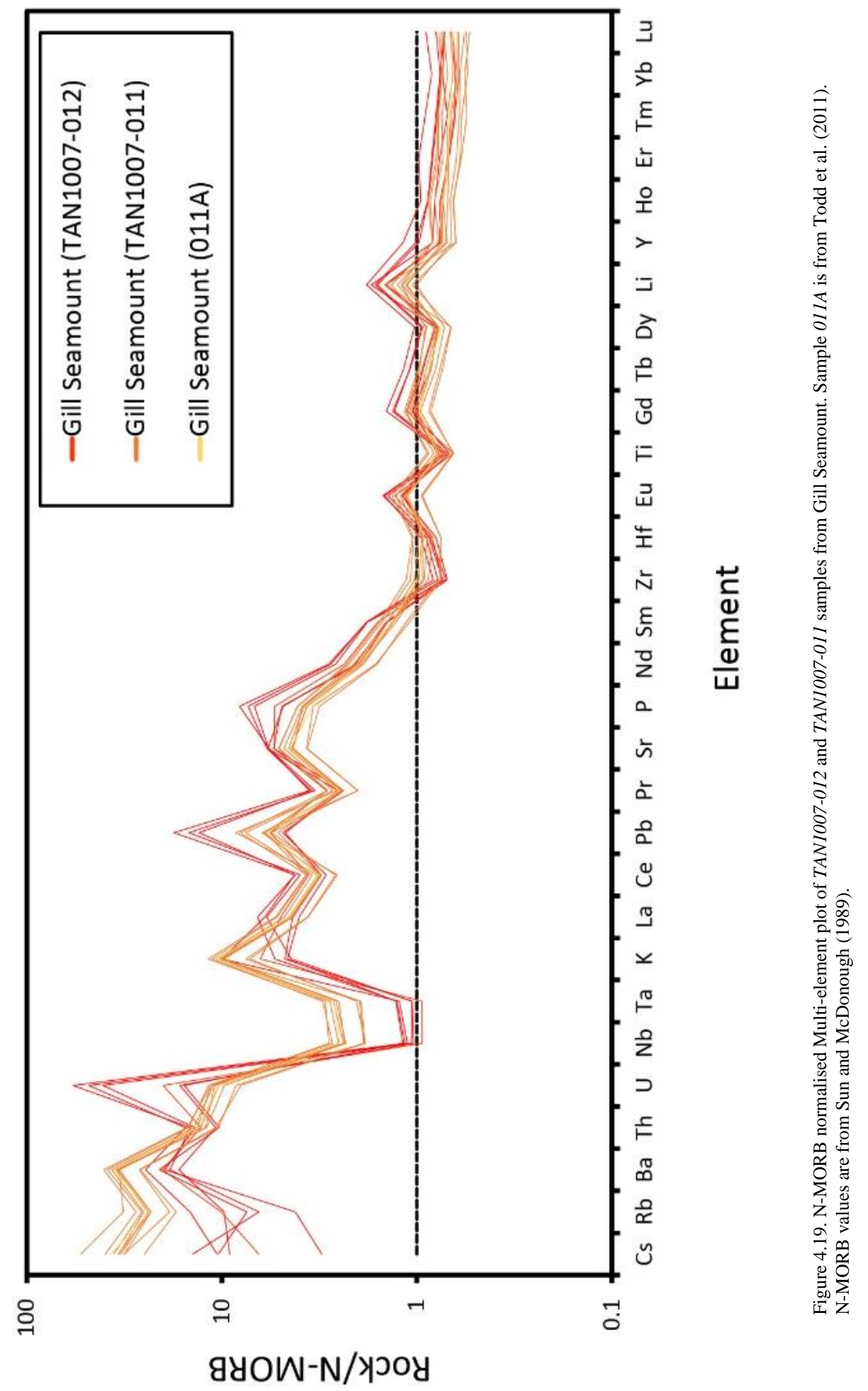




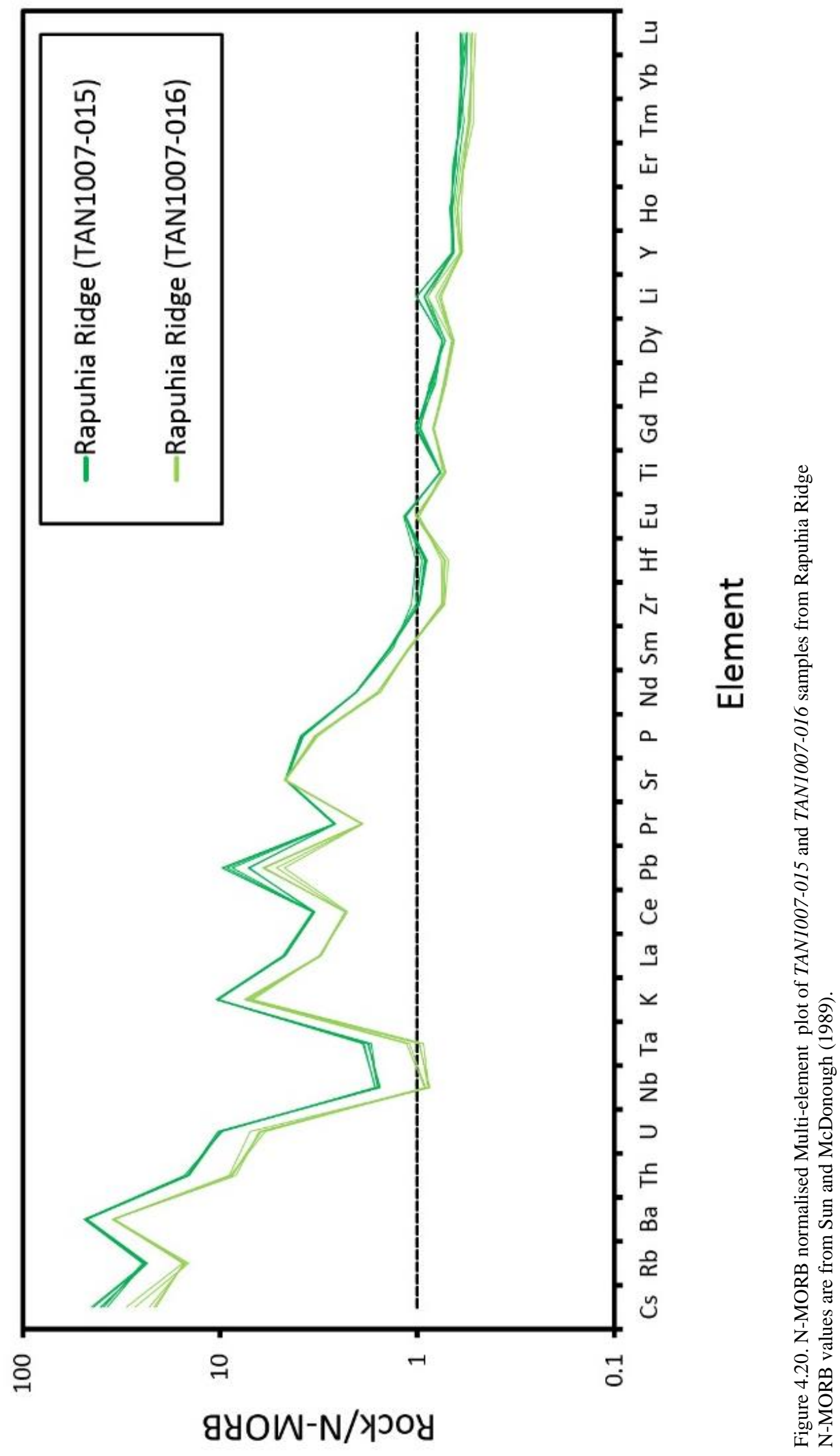




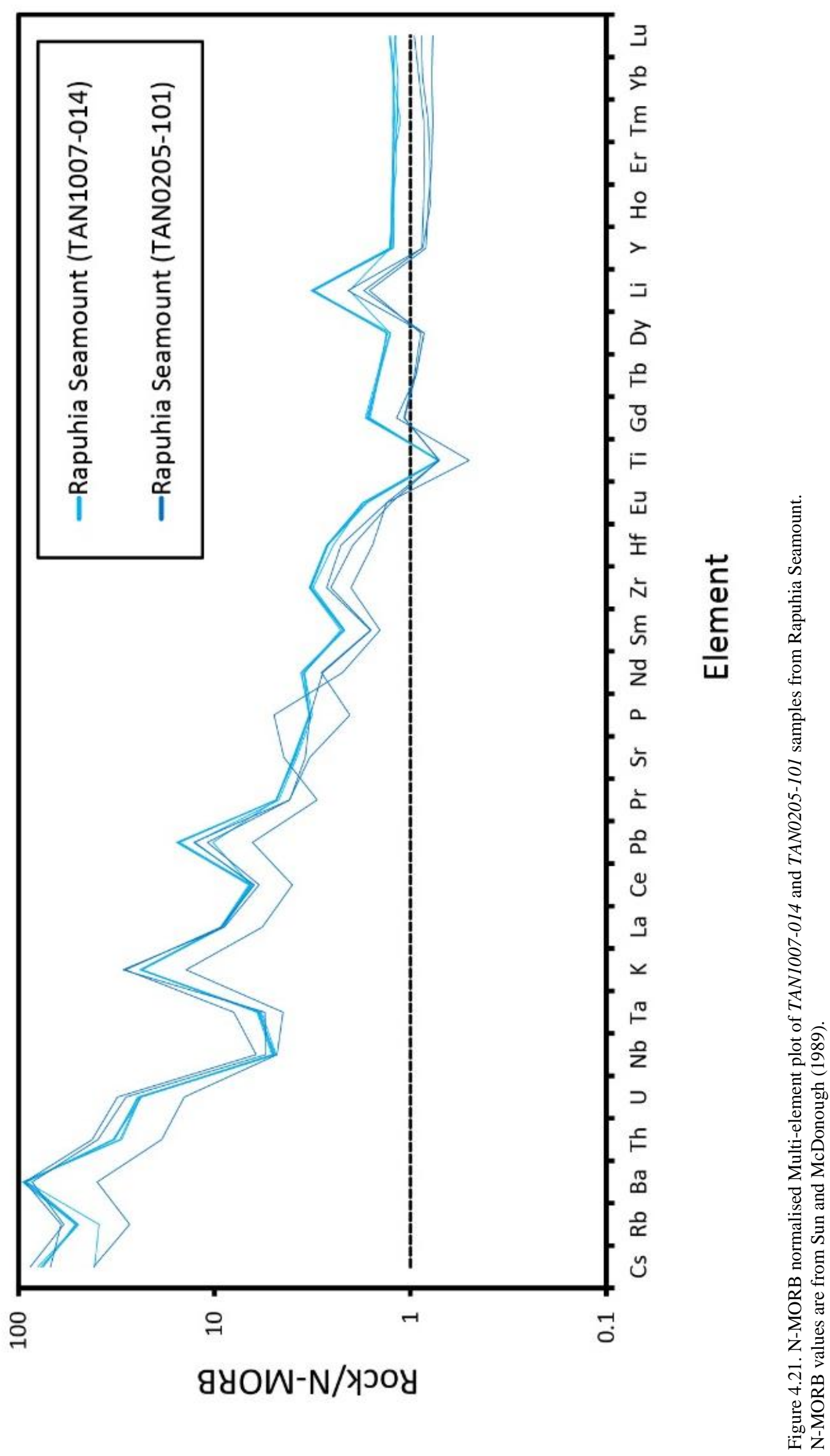




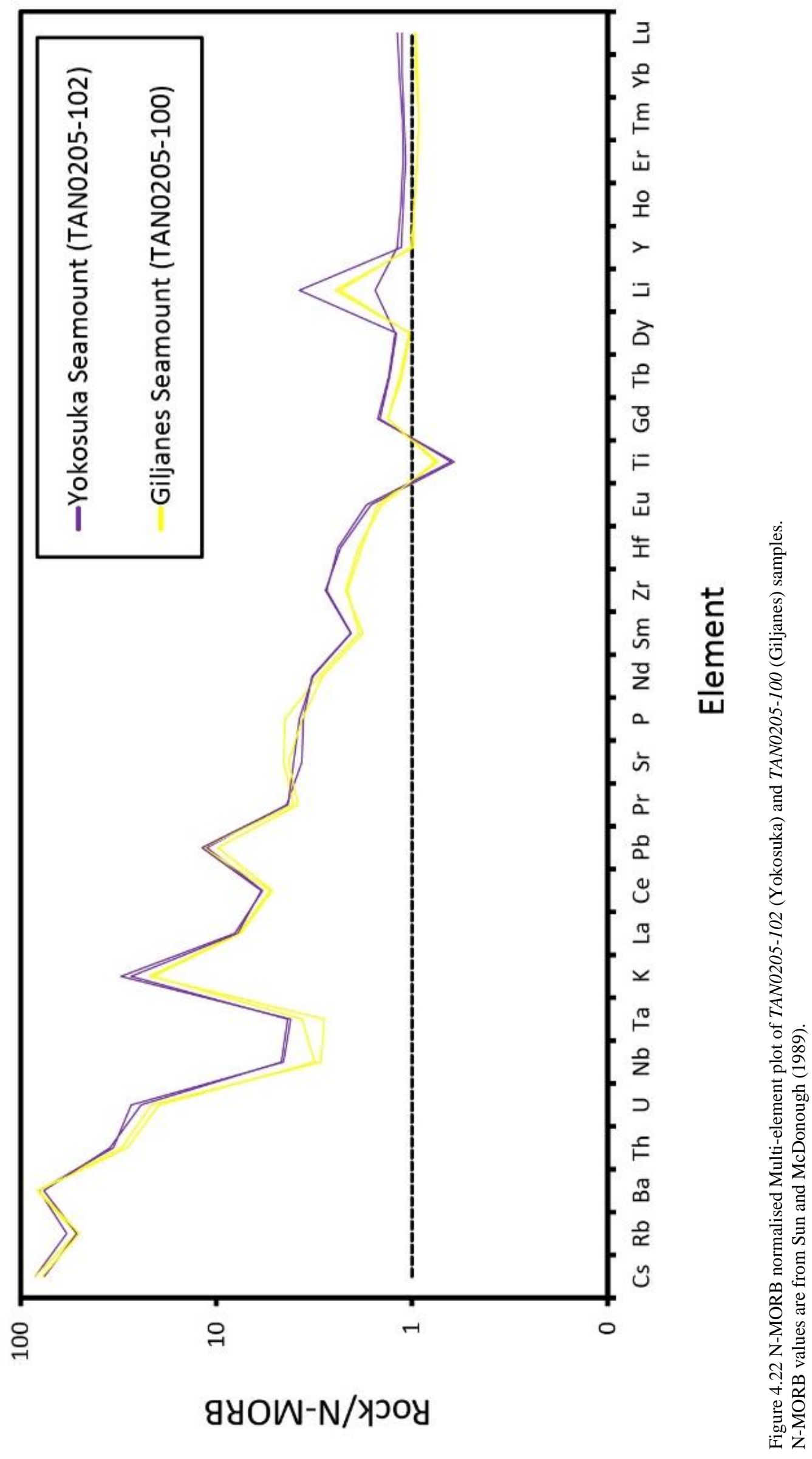




\subsubsection{Geochemistry of Gill Seamount}

Samples from both the summit (dredge TAN1007-012) and flank (TAN1007012) of Gill Summit generally overlap in both $\mathrm{Al}_{2} \mathrm{O}_{3}$ (ca. 13.1 - 17.9 wt \%) and $\mathrm{MgO}$ content (ca. 5.2 - 12.8 wt \%), (Figure 4.23). However, samples display significant contrast in terms of other bulk rock major oxide and trace element concentrations. Flank samples contain higher contents of $\mathrm{SiO}_{2}$ (ca. 49 - 53 wt \%), $\mathrm{K}_{2} \mathrm{O}$ (ca. 0.52 - 0.85 wt \%), $\mathrm{Na}_{2} \mathrm{O}$ (ca. $1.9-2.6 \mathrm{wt} \%$ ) and $\mathrm{TiO}_{2}$ (ca. 0.8 - $1.1 \mathrm{wt} \%$ ), than samples from the summit suite (Figures 4.17, 4.23). Summit samples contain greater $\mathrm{CaO}$ (ca. 12.8 13.7 wt \%), $\mathrm{FeO}^{*}$ (ca. $9.4-11.1$ wt \%), and $\mathrm{P}_{2} \mathrm{O}_{5}$ (ca. $0.3-0.5$ wt \%), than the flank suite of lavas (Figure 4.23).

Summit samples from Gill Summit do not appear to follow the same trends as other back-arc stratovolcano lavas investigated in this study (Figures 4.17, 4.23). In contrast to the flank suite, the $\mathrm{P}_{2} \mathrm{O}_{5}$ content from the summit suite correlates negatively with increasing $\mathrm{SiO}_{2}$. On the N-MORB-normalised multi-element plot in Figure 4.19, concentrations are generally more variable than for element concentrations from the flank suite. For example, concentrations of $\mathrm{Cs}, \mathrm{Rb}$ and $\mathrm{Ba}$ are distinctly lower in summit lavas than in flank lavas, and contain noticeably higher concentrations of $U$ and $\mathrm{P}$.

Whole rock compositions of the flank suite follow similar trends to whole rock analyses from the other back-arc stratovolcanoes investigated in this study (Figures $4.18,4.23)$. They have sub-parallel trace element patterns. When compared with $\mathrm{N}$ $\mathrm{MORB}$, they are characterised by elevated $\mathrm{Nb}$ concentrations and negative $\mathrm{Zr}$ and $\mathrm{Hf}$ anomalies (Hf/Hf* ranges from $\sim 0.67-0.72)^{4}$ (Figure 4.18). Two basalts from the flank of Gill Summit are characterised by high Mg contents (ca. 12-6 - 12.8 wt \% $\mathrm{MgO}$ ) and high Ni contents (ca. 247 - 254 ppm Ni). The single basalt previously analysed by Todd et al. (2011) shows similar major and trace element characteristics to other flank samples analysed in this study (Figure 4.19).

Samples from Gill Summit are characterised by relatively steep chondritenormalised REE patterns $\left((\mathrm{La} / \mathrm{Yb})_{\mathrm{N}}=3.1-4.6\right)$, (Figure 4.24).

${ }^{4} \mathrm{Hf} / \mathrm{Hf} *=\mathrm{Hf}_{\mathrm{N}} /\left(\mathrm{Nd}_{\mathrm{N}}{ }^{1 / 4} * \mathrm{Sm}_{\mathrm{N}}{ }^{3 / 4}\right)$, where all samples are normalised to chondrite values from McDonough and Sun (1995). Equation comes from (Duggen et al., 2007). 

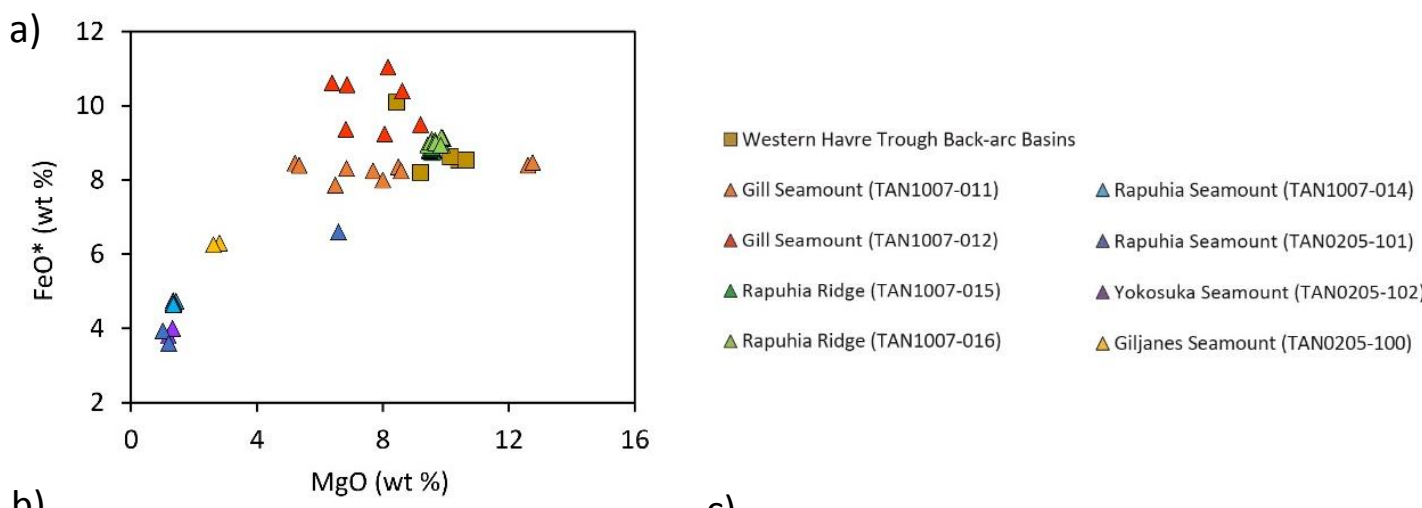

b)

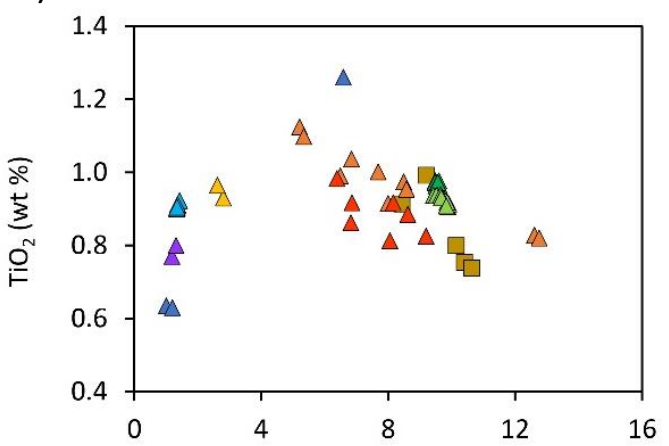

c)
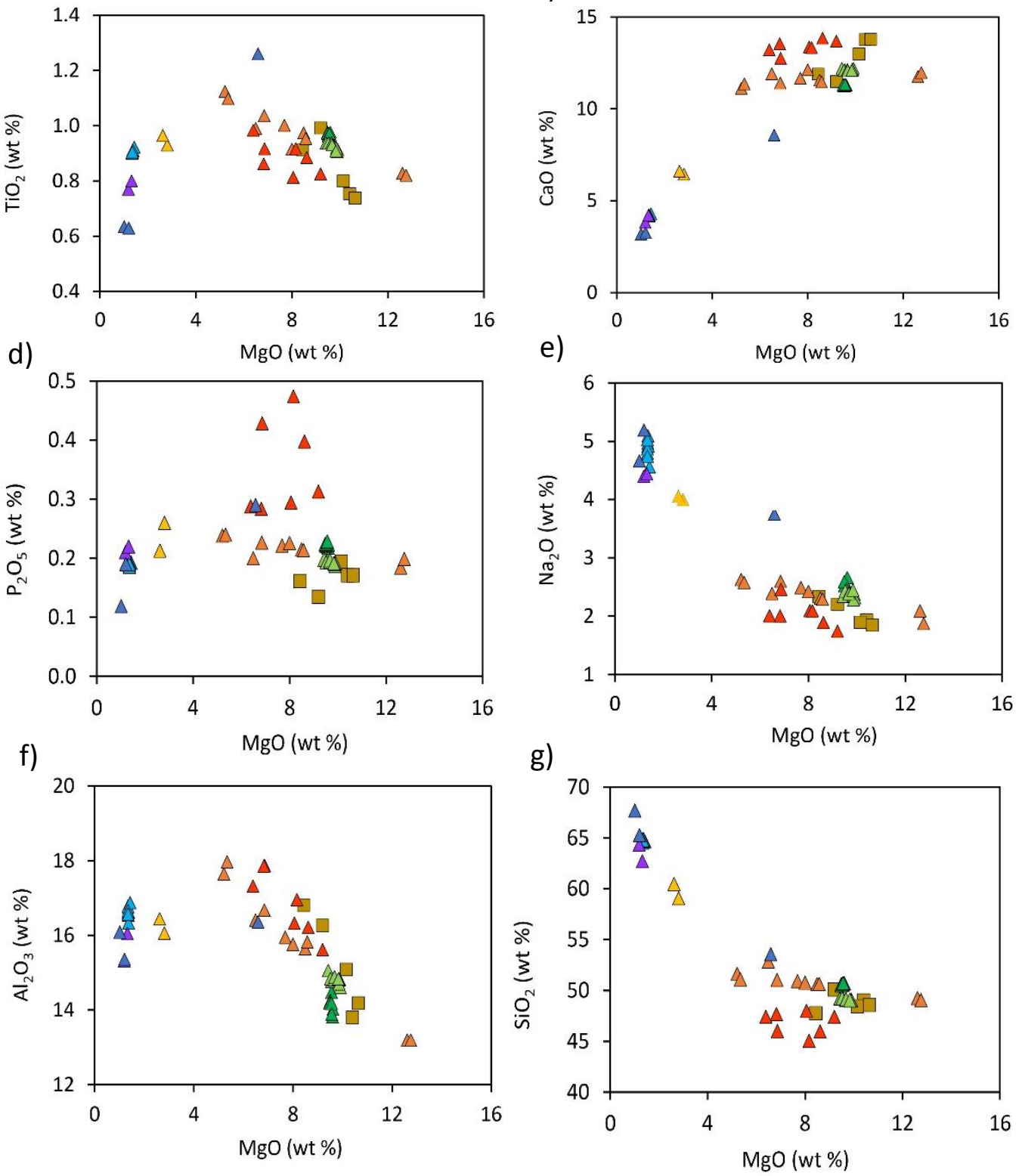

Figure 4.23. Major oxide plots of a) $\mathrm{FeO}^{*}$, b) $\mathrm{TiO}_{2}$, c) $\mathrm{CaO}$, d) $\mathrm{P}_{2} \mathrm{O}_{5}$, e) $\mathrm{Na}_{2} \mathrm{O}$, f) $\mathrm{Al}_{2} \mathrm{O}_{3}$, and g) $\mathrm{SiO}_{2}$, versus $\mathrm{MgO}$.

All values are in wt \%. Symbols are the same in all plots 
a)

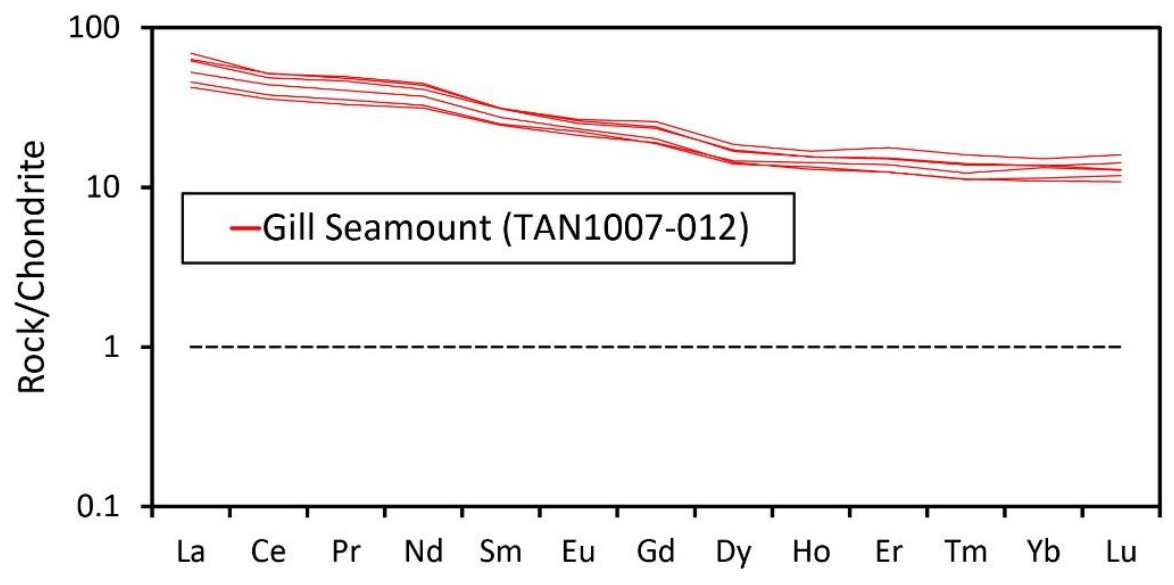

b)

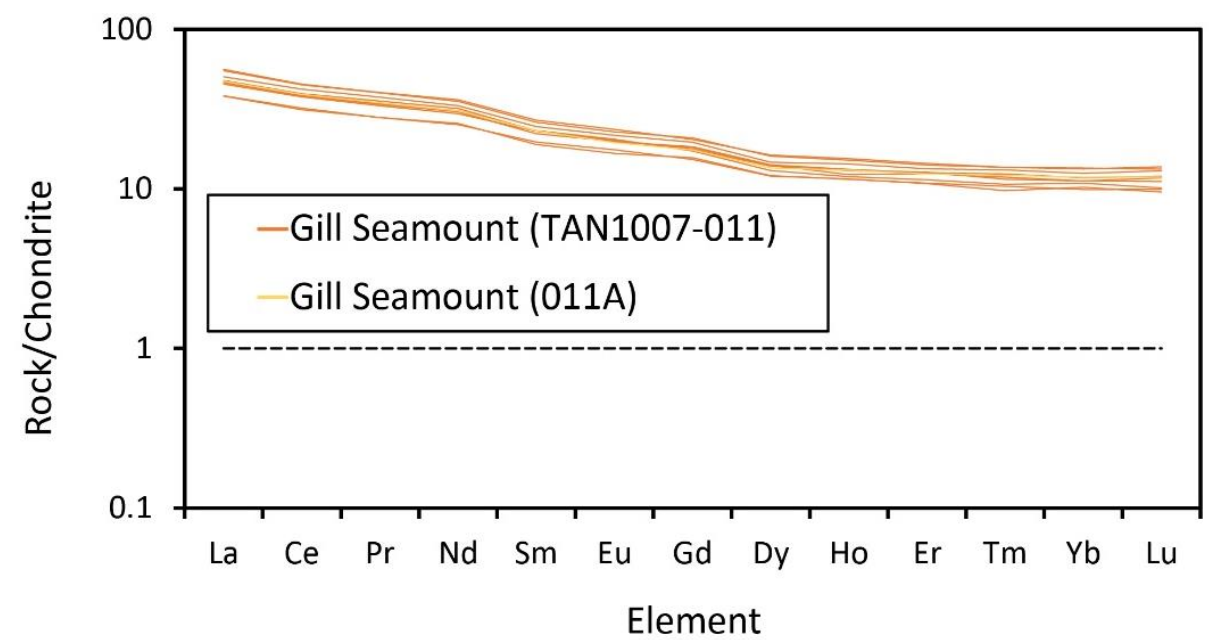

Figure 4.24. Chondrite-normalised REE plots for samples from Gill Seamount.

Values for samples are from a) TAN1007-012, and b) TAN1007-011. Chondrite values are from McDonough and Sun (1995).

\subsubsection{Geochemistry of Rapuhia Ridge}

Lavas from both dredges of Rapuhia Ridge contain similar contents of $\mathrm{MgO}$ (ca. 9.4 - 9.9 wt \%), (Figure 4.23). Compared to most lavas from the flank of Gill, they have similar contents of $\mathrm{SiO}_{2}$ (ca. 49 - 51 wt \%), $\mathrm{Na}_{2} \mathrm{O}$ (ca. $2.3-2.7$ wt \%), $\mathrm{CaO}$ (ca. 11.3 - 12.2 wt \%) and $\mathrm{TiO}_{2}$ (ca. 0.9 - 1 wt \%), but lower contents of $\mathrm{Al}_{2} \mathrm{O}_{3}$ (ca. 13.8$15.1 \mathrm{wt} \%$ ), and higher contents of $\mathrm{FeO}^{*}$ (ca. 8.7 - $9.2 \mathrm{wt} \%$ ) (Figure 4.23). They show significant differences in other element concentrations between the two dredge sites. Samples from dredge TAN1007-015 are characterised by higher contents of $\mathrm{K}_{2} \mathrm{O}$ and $\mathrm{SiO}_{2}$, and are more enriched in concentrations $\mathrm{Hf}, \mathrm{Zr}$, and $\mathrm{Cr}$ (Figures 4.18, 4.23). 
Lavas from the TAN1007-016 suite contain higher contents of $\mathrm{FeO} *, \mathrm{CaO}$ and $\mathrm{Al}_{2} \mathrm{O}_{3}$ (Figure 4.23). Ni content is also higher in the TAN1007-016 lavas (Figure 4.18).

Samples from both lava suites follow sub-parallel trace element patterns on the N-MORB-normalised plot in Figure 4.20. All Rapuhia Ridge lavas analysed are characterised by negative $\mathrm{Zr}$ and $\mathrm{Hf}$ anomalies (Hf/Hf* $\sim 0.63-0.76)$. However, the TAN1007-015 lava suite is characterised by elevated incompatible trace element concentrations when compared with the TAN1007-016 lava suite (Figure 4.20). When compared with $\mathrm{N}-\mathrm{MORB}$ concentrations, $\mathrm{Nb}$ contents are elevated in lavas from the TAN1007-015 suite, but are slightly depleted in lavas from the TAN1007-016 suite (Figure 4.20).

a)

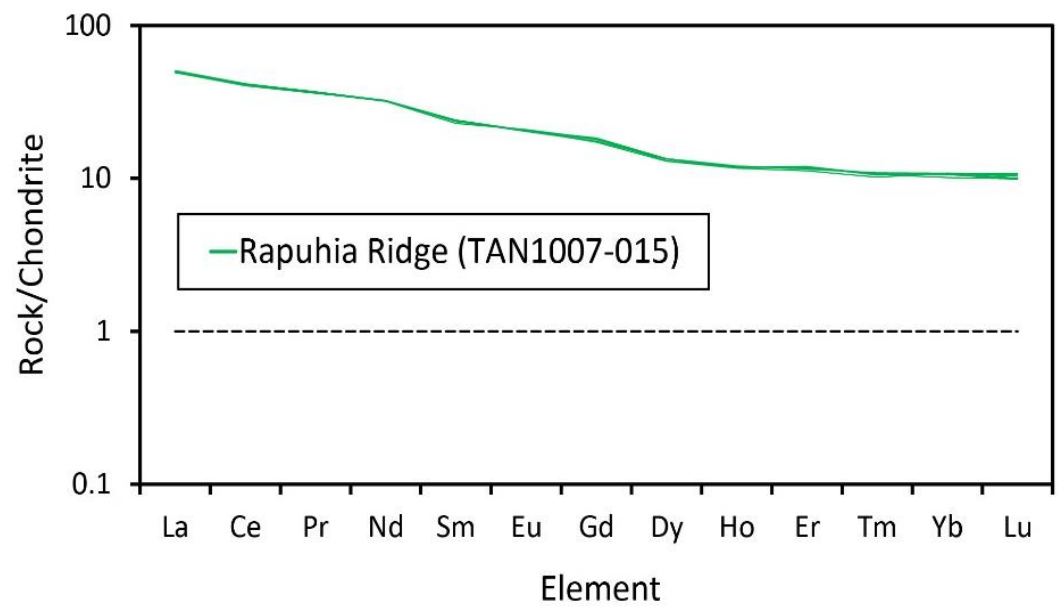

b)

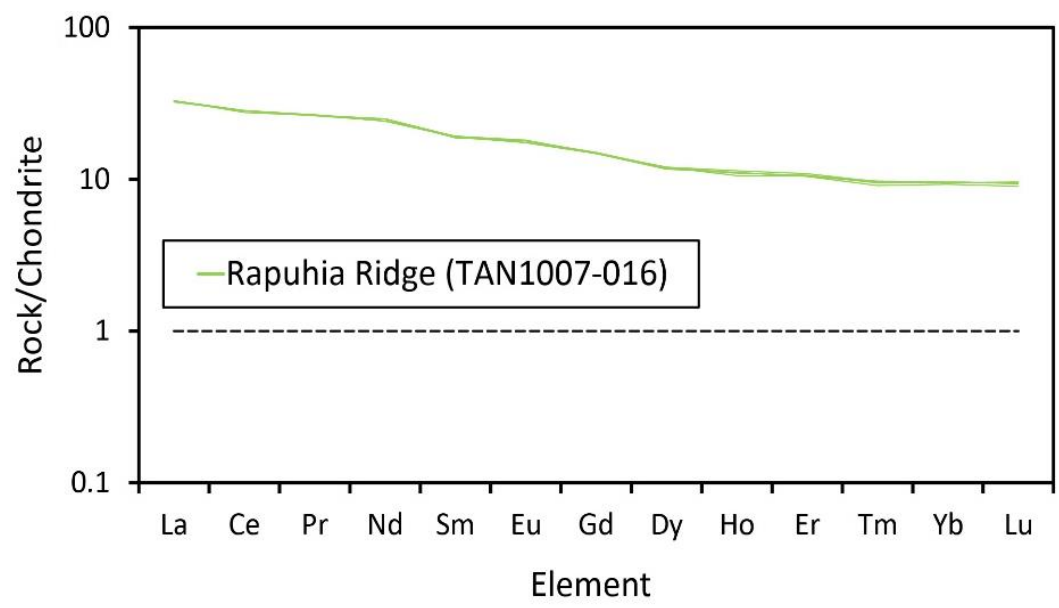

Figure 4.25. Chondrite-normalised REE plots for samples from Rapuhia Ridge.

a) Element normalised values from TAN1007-015 samples. b) Element normalised values for TAN1007-016 samples. Chondrite values are from McDonough and Sun (1995). 
Chondrite-normalised REE patterns are slightly steeper for TAN1007-015 samples than for those from the TAN1007-016 suite $\left(\left(\mathrm{La} / \mathrm{Yb}_{\mathrm{N}}\right)\right.$ range from ca. 4.3-4.6 for TAN1007-015 samples, and ca. 3.2-3.4 for TAN1007-016 lavas), (Figure 4.25).

\subsubsection{Geochemistry of Rapuhia Seamount}

With the exception of the basaltic-andesite sample (6.6 wt \% MgO), lavas from Rapuhia Seamount generally have similar MgO contents (ca. 1.1 - 1.2 wt \%), (Figure 4.23). When compared with the basaltic samples from Gill and Rapuhia Ridge, they are characterised by distinctively lower contents of $\mathrm{FeO} *$ (ca. $3.6-4.7$ wt \%), $\mathrm{CaO}$ (ca. $3.2-4.2 \mathrm{wt} \%$ ) and $\mathrm{TiO}_{2}$ (ca. $0.6-0.9 \mathrm{wt} \%$ ), and significantly higher contents of $\mathrm{SiO}_{2}$ (ca. 64.6 - $67.7 \mathrm{wt} \%$ ) and $\mathrm{Na}_{2} \mathrm{O}$ (ca. 4.6 - 5.2 wt \%), (Figure 4.23). They also contain lower concentrations of $\mathrm{Cr}$ and $\mathrm{Ni}$, and greater concentrations of $\mathrm{Zr}$ and $\mathrm{Hf}$ (Figure 4.18).

Samples from the TAN1007-014 suite have higher contents of $\mathrm{FeO}^{*}, \mathrm{CaO}$, $\mathrm{TiO}_{2}$ and $\mathrm{Al}_{2} \mathrm{O}_{3}$, than the TAN1007-101 dacites, but lower contents of $\mathrm{SiO}_{2}$ and $\mathrm{Na}_{2} \mathrm{O}$, (Figure 4.23). A single dacitic sample from the TAN0205-101 suite is characterised by noticeably higher contents of $\mathrm{P}_{2} \mathrm{O}_{5}$ than other Rapuhia Seamount samples (Figure 4.23). In comparison to the dacitic samples of Rapuhia Seamount, the basaltic-andesite sample has higher contents of $\mathrm{MgO}, \mathrm{CaO}, \mathrm{FeO}^{*}$ and $\mathrm{TiO}_{2}$, (Figure 4.23).

With the exception of Ti and HREE, samples from Rapuhia Seamount are characterised by elevated trace element concentrations with respect to N-MORB (Figure 4.21). All lavas contain positive $\mathrm{Zr}$ and $\mathrm{Hf}$ anomalies ( $\mathrm{Hf} / \mathrm{Hf} *$ ranges from 1.12 - 1.36). Dacitic samples from the TAN1007-014 suite have similar element NMORB normalised patterns, and compared with TAN0205-101 samples, are enriched in most REE (Figure 4.21). A single dacitic sample from the TAN0205-101 suite is characterised by less elevated concentrations in LILE and LREE compared with other Rapuhia samples. The basaltic-andesite sample (TAN0205-101-02) has similar higher concentrations of LILE to TAN1007-014 lavas, but lower values of HREE.

Samples from Rapuhia Seamount are characterised by relatively steep chondrite-normalised REE patterns (Figure 4.26). Ratios of $(\mathrm{La} / \mathrm{Yb})_{\mathrm{N}}$ range from ca. 
4.1 - 4.3 for TAN1007-014 samples, but are higher for two samples from the TAN0205-101 suite, where $(\mathrm{La} / \mathrm{Yb})_{\mathrm{N}}=$ ca. 5.7.

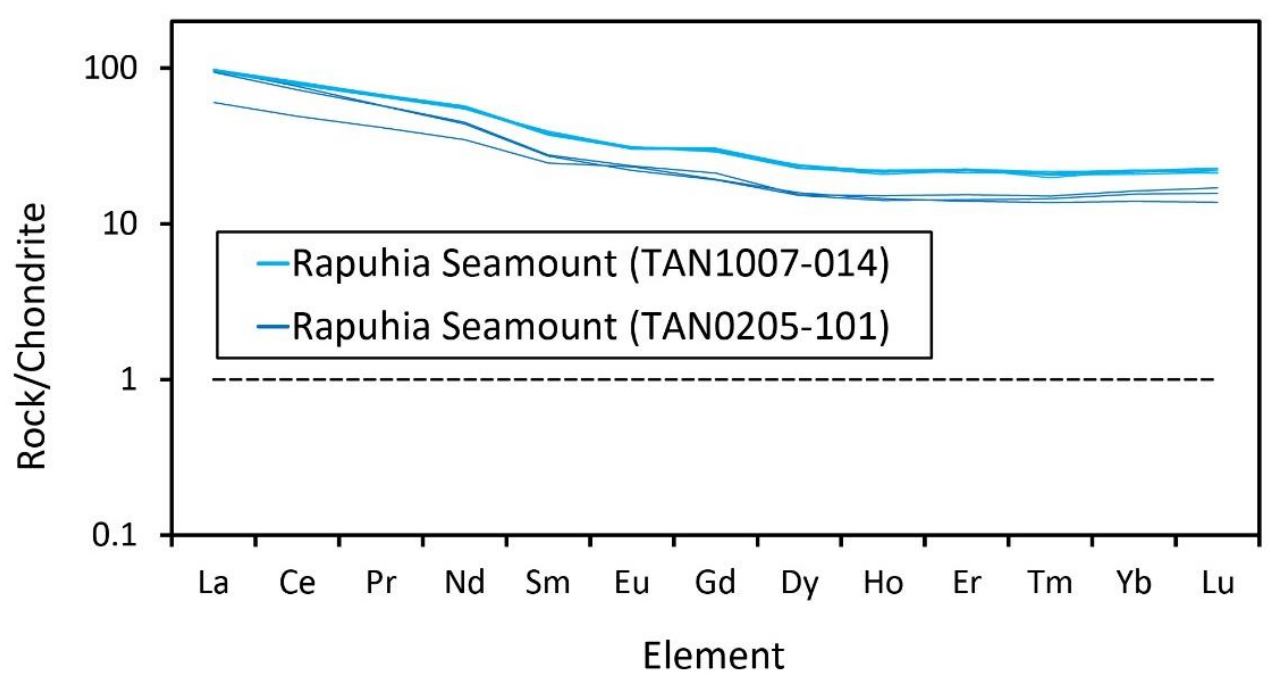

Figure 4.26. REE chondrite-normalised values for TAN0205-101 and TAN1007-014 samples from Rapuhia Seamount.

Chondrite values are from McDonough and Sun (1995).

\subsubsection{Geochemistry of Yokosuka}

The two dacites collected from Yokosuka Seamount have similar compositions to the dacitic samples analysed from Rapuhia Seamount (Figures 4.17, 4.18, 4.23). Major oxide compositions are also given in Wright et al. (2006). With the exception of $\mathrm{Ti}$, all trace element concentrations are elevated with respect to $\mathrm{N}-\mathrm{MORB}$ values (Figure 4.22). Both samples are associated with positive $\mathrm{Zr}$ and $\mathrm{Hf}$ anomalies. Chondrite-normalised REE patterns are relatively steep, where $(\mathrm{La} / \mathrm{Yb})_{\mathrm{N}}=$ ca. 3.9 (Figure 4.27).

\subsubsection{Geochemistry of Giljanes Seamount}

The two andesites collected from Giljanes Seamount contain $\mathrm{MgO}$ contents that range from 2.62 - $2.81 \mathrm{wt} \%$ (Figure 4.23). Major oxide compositions of sample TAN0205-100-02 are given in Wright at al. (2006). When compared with dacites from Rapuhia Seamount and Yokosuka Seamount, the two samples from Giljanes Seamount are characterised by higher contents of $\mathrm{FeO}^{*}$ (ca. 6.3 wt \%) and $\mathrm{CaO}$ (ca. 
6.5 - 6.6 wt \%), but lower concentrations of $\mathrm{SiO}_{2}$ (ca. 59.09 - 60.47 wt \%), (Figures $4.18,4.23)$. Most trace element concentrations are enriched with respect to N-MORB values, but concentrations of Ti and HREE are depleted (Figure 4.22). Both samples are characterised by relatively steep chondrite-normalised REE patterns, where $(\mathrm{La} / \mathrm{Sm})_{\mathrm{N}}=$ ca. 4.5, (Figure 4.27).

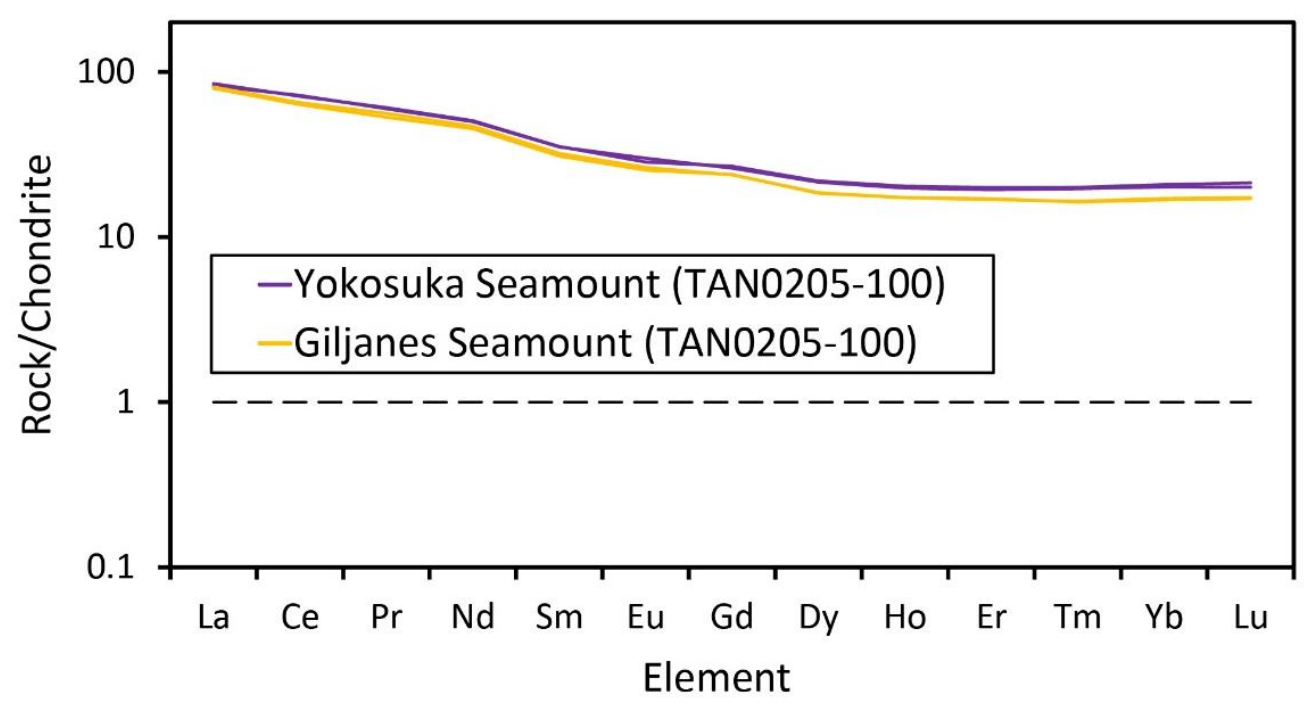

Figure 4.27. REE chondrite-normalised plot for samples from Yokosuka Seamount (TAN0205-102) and Giljanes Seamount (TAN0205-100).

Chondrite values are from McDonough and Sun (1995).

\subsubsection{Geochemistry of Western Havre Trough Back-Arc Basin Basalts}

Back-arc basin basalts (BABB) collected from the western Havre Trough have $\mathrm{MgO}$ contents that range from ca. 8.4 - $10.6 \mathrm{wt} \%$ (Figure 4.23). Compared with analyses of Gill Seamount and Rapuhia Ridge lavas, they have similar contents of FeO*, $\mathrm{CaO}, \mathrm{TiO}_{2}, \mathrm{Na}_{2} \mathrm{O}, \mathrm{Al}_{2} \mathrm{O}_{3}$ and $\mathrm{SiO}_{2}$ (Figure 4.23). A single sample (TAN1513042-01) has lower wt $\% \mathrm{SiO}_{2}$, and elevated wt $\% \mathrm{FeO}^{*}$, when compared with the other BABB analyses (Figures 4.17, 4.23).

The three BABB analysed for trace element concentrations are characterised by enriched LILE, and depletions in HFSE and HREE, with respect to N-MORB values (Figure 4.28). All three samples show significant variation in LILE enrichment, particularly in concentrations of $\mathrm{Cs}, \mathrm{Pb}$ and $\mathrm{Li}$ (Figure 4.28). All three BABB are depleted in $\mathrm{Nb}$ with respect to $\mathrm{N}-\mathrm{MORB}$ values. Of the three $\mathrm{BABB}$, sample TAN1513-042-01 is characterised by the most elevated concentrations in Cs and Li, 
and most depleted concentrations in $\mathrm{Nb}$ and $\mathrm{Ta}$. The other two BABB appear to have sub-parallel N-MORB normalised trace element patterns, with sample TAN1513-04201 generally characterised by more elevated trace element concentrations than sample TAN1513-040-02.

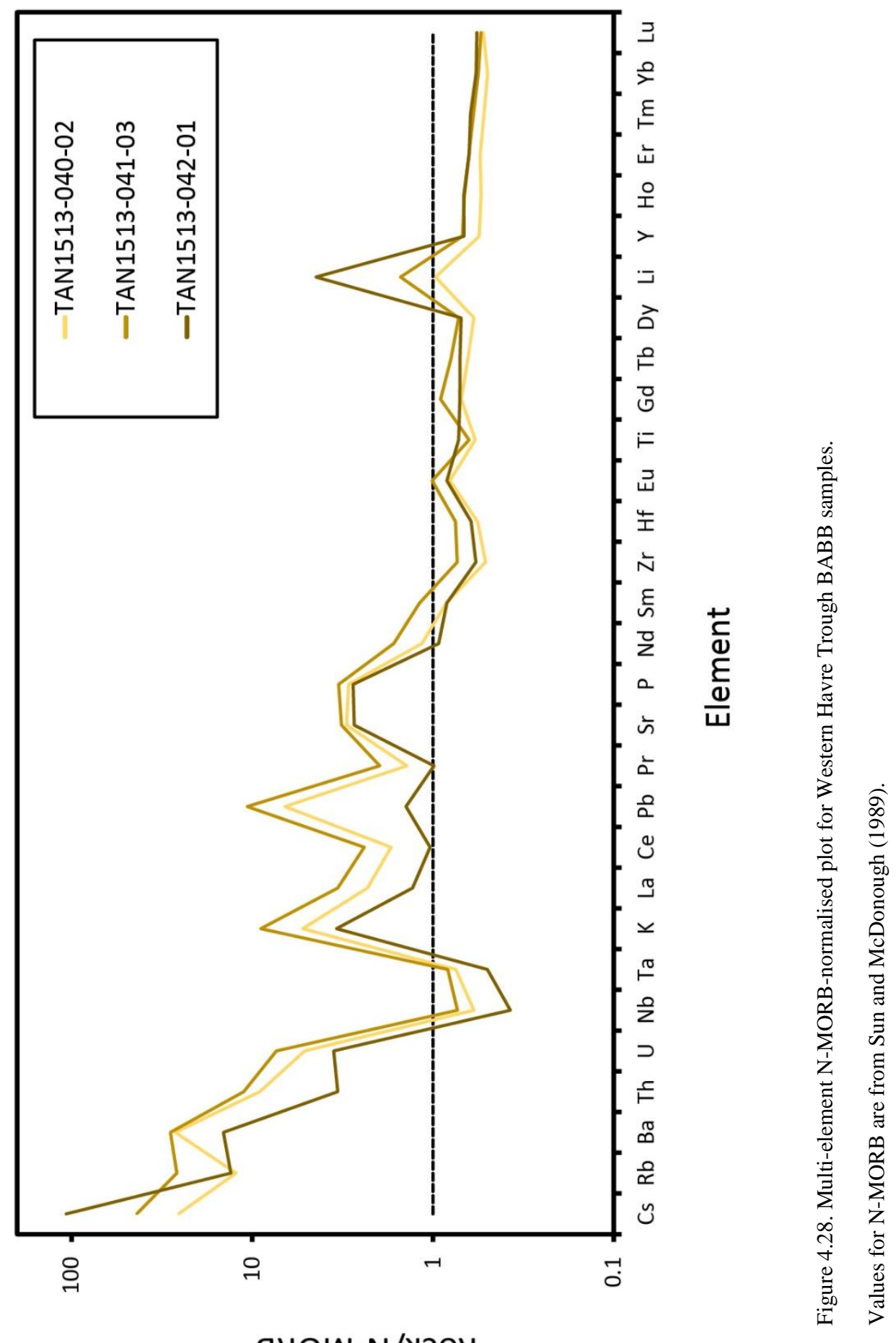

gyow-N/^эоy 


\subsection{Mineralogy}

A primary aim of this study is to report the first mineral analyses from backarc stratovolcano lavas, and compare compositions to those from the present-day Kermadec volcano arc-front, and the remnant Colville Arc. The lavas erupted from the back-arc stratovolcanoes in the southern Havre Trough display a diverse range of petrographic and geochemical characteristics, both between and within each lava suite (Sections $4.1 \& 4.2$ ). Representative samples from each lava suite were selected for EPMA analysis (Table 4.1). Samples were selected on the basis of petrography and whole rock geochemistry, in order to analyse a diverse range of mineral assemblages. Because all the samples are characterised by a holocrystalline groundmass, glass contents were relatively minor in volume for each sample. In addition, glassy regions in residual groundmass were generally microcrystalline, and/or $<5-10 \mu \mathrm{m}$ in size. Finding glassy regions that would be large enough to give a representative analysis using a $10 \mu \mathrm{m}$ diameter beam was not possible, so glass was not analysed in this study.

\begin{tabular}{|c|c|c|c|}
\hline Sample & Volcano & Whole Rock $\mathrm{SiO}_{2}($ wt \%) & Mineral Assemblage \\
\hline TAN1007-011-02 & Gill (flank) & 49.25 & Olivine $>$ Clinopyroxene $>$ Plagioclase \\
\hline TAN1007-011-04 & Gill (flank) & 50.77 & Olivine > Clinopyroxene \\
\hline TAN1007-011-06 & Gill (flank) & 51.63 & Clinopyroxene $>$ Olivine $>$ Plagioclase \\
\hline TAN1007-012-01 & Gill (summit) & 47.41 & Clinopyroxene $>$ Olivine $>$ Plagioclase \\
\hline TAN1007-012-03 & Gill (summit) & 47.69 & Clinopyroxene $>$ Plagioclase \\
\hline TAN1007-012-08 & Gill (summit) & 47.42 & Plagioclase $>$ Clinopyroxene $>$ Olivine \\
\hline TAN1007-015-03 & Rapuhia Ridge & 50.68 & Clinopyroxene $>$ Olivine \\
\hline TAN1007-015-04 & Rapuhia Ridge & 50.55 & Clinopyroxene $>$ Olivine \\
\hline TAN1007-016-01 & Rapuhia Ridge & 49.11 & Olivine $>$ Orthopyroxene $>$ Clinopyroxene \\
\hline TAN1007-016-03 & Rapuhia Ridge & 49.20 & Olivine $>$ Orthopyroxene $>$ Clinopyroxene \\
\hline TAN1007-014-03 & Rapuhia & 64.65 & Plagioclase $>$ Clinopyroxene \\
\hline TAN1007-014-05 & Rapuhia & 64.75 & Plagioclase $>$ Clinopyroxene \\
\hline TAN0205-101-02 & Rapuhia & 67.71 & Plagioclase $>$ Amphibole \\
\hline TAN0205-101-03 & Rapuhia & 65.28 & Plagioclase $>$ Amphibole \\
\hline TAN0205-100-03 & Giljanes & 60.47 & Plagioclase $>$ Clinopyroxene \\
\hline
\end{tabular}

Table 4.1. Samples selected for electron probe micro analysis.

Whole rock $\mathrm{SiO}_{2}$ and bulk mineral assemblage for each sample are shown for comparison. 


\subsubsection{Gill Seamount Crystal Chemistry}

\section{Olivine}

Olivine phenocrysts from selected Gill Seamount samples have Fo contents that range from Fo79-90 in both the flank and summit samples (Figure 4.29). Samples generally show an increase in Fo content with increasing whole rock $\mathrm{Mg} \#$. However, a single sample from the flank of Gill (TAN1007-011-02) contains olivine phenocrysts with lower Fo contents than those from more Mg-poor lavas (Figure 4.29). Sample TAN1007-011-02 is characterised by high Mg content ( $\mathrm{Mg} \#=72.8$, (Figure 4.29)), and coarse euhedral olivine phenocrysts that are up to ca. $5 \mathrm{~mm}$ long. Fo contents of olivine in this sample range from Fo82-90 (Figure 4.29).

When compared with sample TAN1007-011-02, other samples from Gill Seamount have olivine phenocrysts that are generally finer-grained (ca. $1-3 \mathrm{~mm}$ long). These samples are characterised by Fo contents that do not vary by more than 6 mol. \% (Figure 4.29).

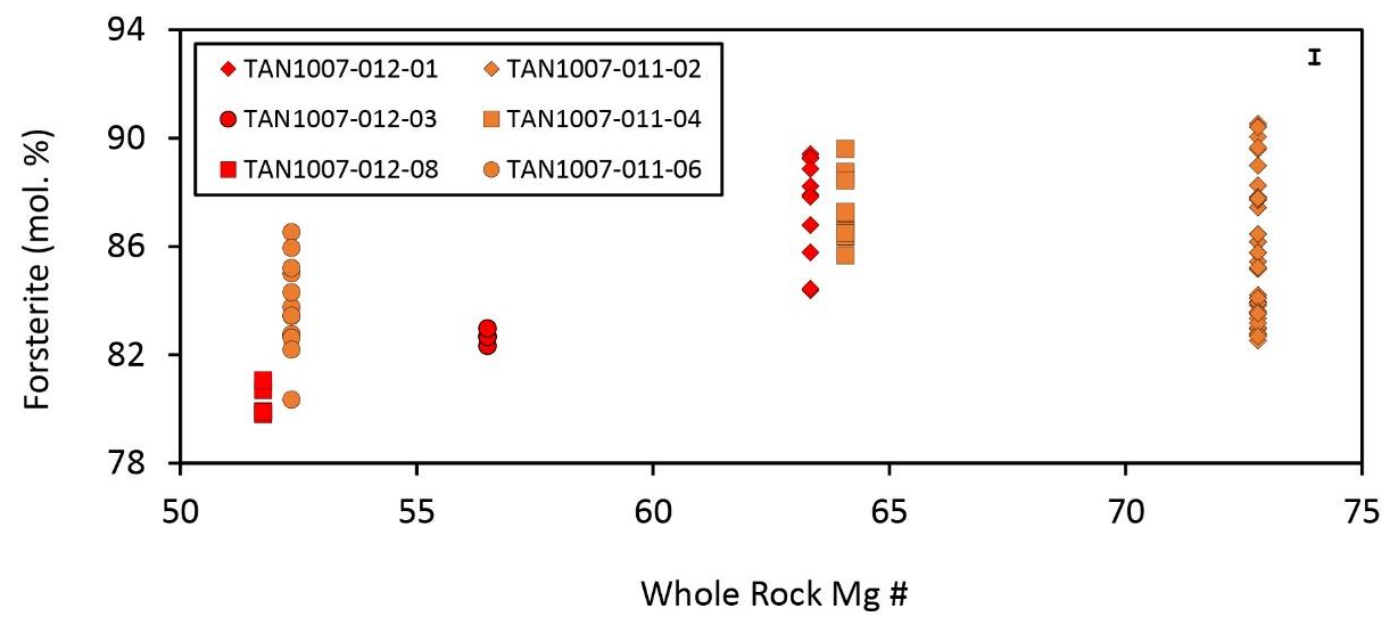

Figure 4.29. Plot showing the relationship between Olivine forsterite (Fo) content and whole rock $\mathrm{Mg} \#$ for samples analysed from Gill Seamount.

All red data points represent analyses of olivine phenocrysts from the summit samples (dredge TAN1007-012), and all orange data points represent analyses of olivine phenocrysts from the flank samples (dredge TAN1007011). The error bars denote 2 SD uncertainty estimates based on repeated analyses of olivine standard Springwater Olivine. 


\section{Clinopyroxene}

Both the summit and flank lavas from Gill Seamount are characterised by clinopyroxene phenocrysts of similar compositions. Summit clinopyroxene contents range from $\mathrm{En}_{49-55} \mathrm{Wo}_{34-43} \mathrm{Fs}_{5-11}$, and clinopyroxene contents from the flank samples range from $\mathrm{En}_{49-56} \mathrm{Wo}_{38-43} \mathrm{Fs}_{4-12}$ (Figure 4.30). Values of $\mathrm{Mg}$ \# range from 81-92 for phenocrysts from both lava suites. For a given value of $\mathrm{Mg} \#$, phenocrysts from the flank suite are characterised by higher values of $\mathrm{Cr}_{2} \mathrm{O}_{3}, \mathrm{TiO}_{2}$, and $\mathrm{Al}_{2} \mathrm{O}_{3}$.

\section{$\underline{\text { Plagioclase }}$}

Plagioclase compositions from Gill Seamount samples range from An77-96 (Figure 4.30). Phenocrysts show minimal variation in composition within a single crystal, where differences in An content are $\leq 5 \mathrm{~mol}$. \% (See Appendix E3). Crystals from the flank and summit of Gill appear to follow distinct trends of increasing Or content with decreasing An content (Figure 4.30). Summit crystals are characterised by higher Or contents for a given value of An, although plagioclase from sample TAN1007-012-01 are characterised by lower values of Or than other summit plagioclase. Both phenocryst and groundmass crystals follow similar trends, with groundmass crystals generally characterised by higher values of Or, and lower values of An (Figure 4.30).

\subsubsection{Rapuhia Ridge Crystal Chemistry}

\section{$\underline{\text { Olivine }}$}

Samples analysed from Rapuhia Ridge contain olivine phenocrysts with Fo contents that range from Fo83-88 (Figure 4.31). Olivine phenocrysts from TAN1007015 samples have a wider range of Fo content than those from the TAN1007-016 suite (Figure 4.31). 
a)

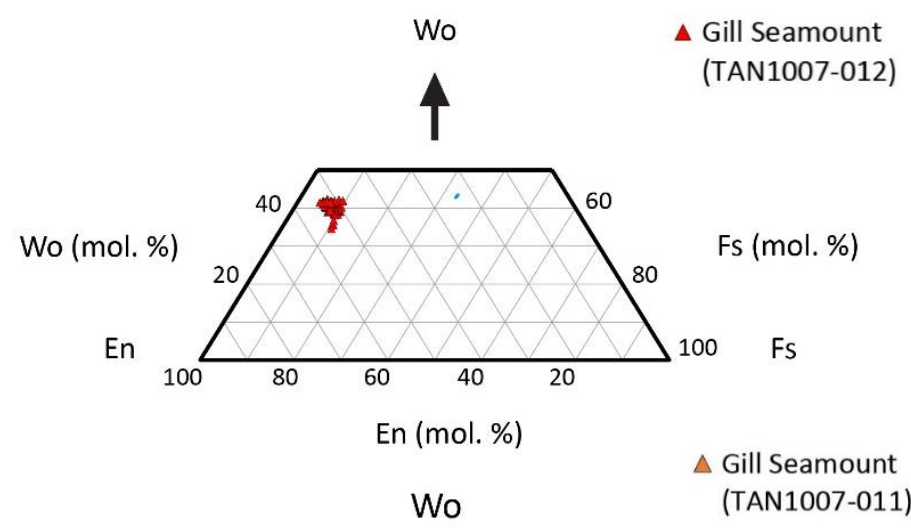

b)

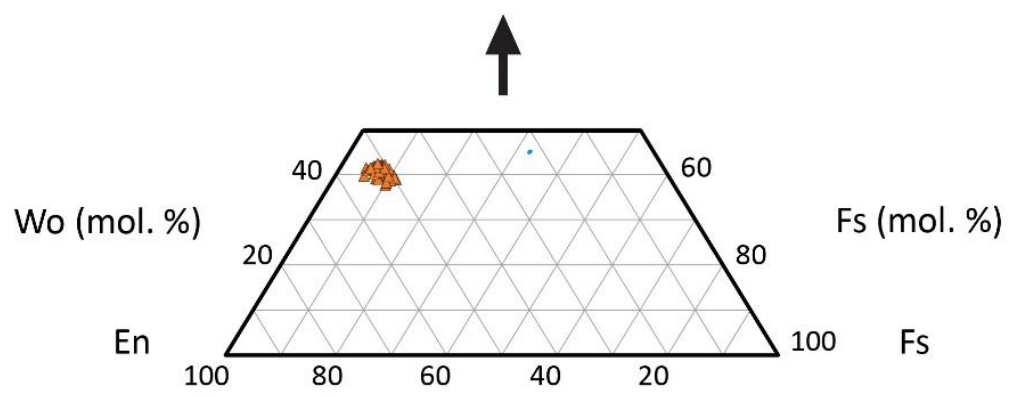

c)

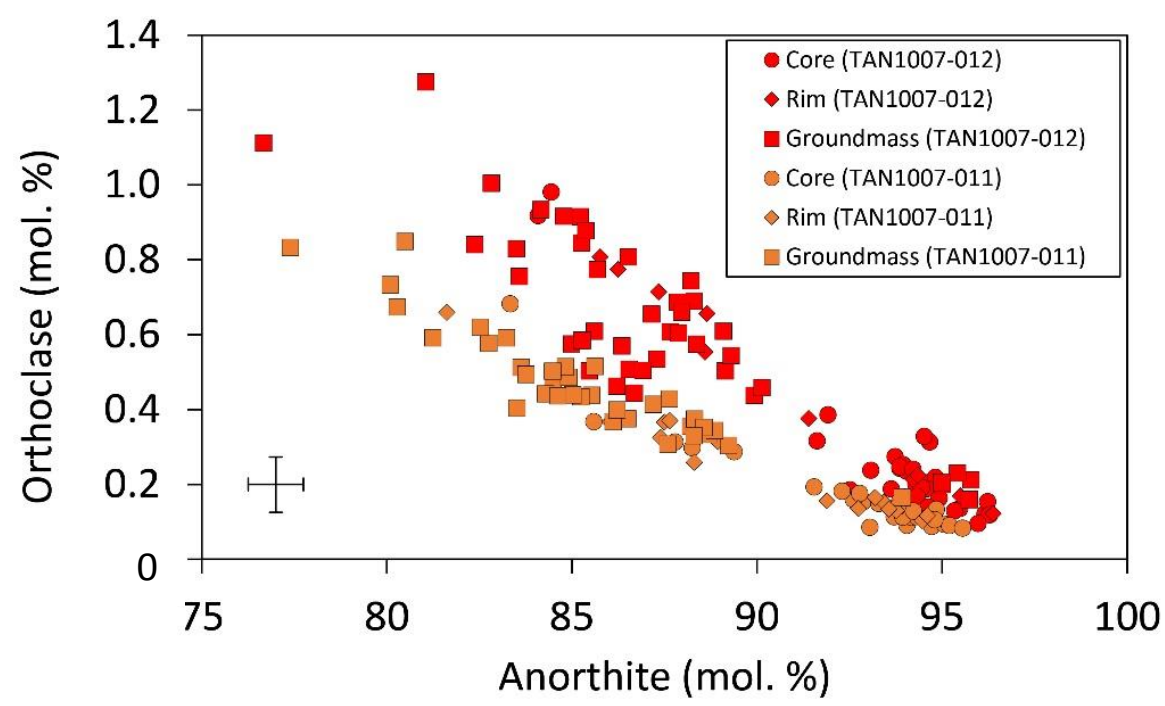

Figure 4.30. Plots of a) clinopyroxene analyses from TAN1007-012 samples, b) clinopyroxene analyses from TAN1007-011 samples, and c) Orthoclase (Or) versus Anorthite (An) content of plagioclase from samples from Gill Seamount.

Wo, En and Fs represent Wollastonite, Enstatite and Ferrosilite. All red data points are associated with analyses from the summit samples (dredge TAN1007-012), and all orange data points are analyses from the flank samples (dredge TAN1007-011). The error ellipses in a) and b) denote 2 SD uncertainty estimates based on repeated analyses of clinopyroxene standard Kakanui Augite. The error bar in c) denotes 2 SD uncertainty estimates based on repeated analyses of plagioclase standard Plagioclase NMNH 115900. 


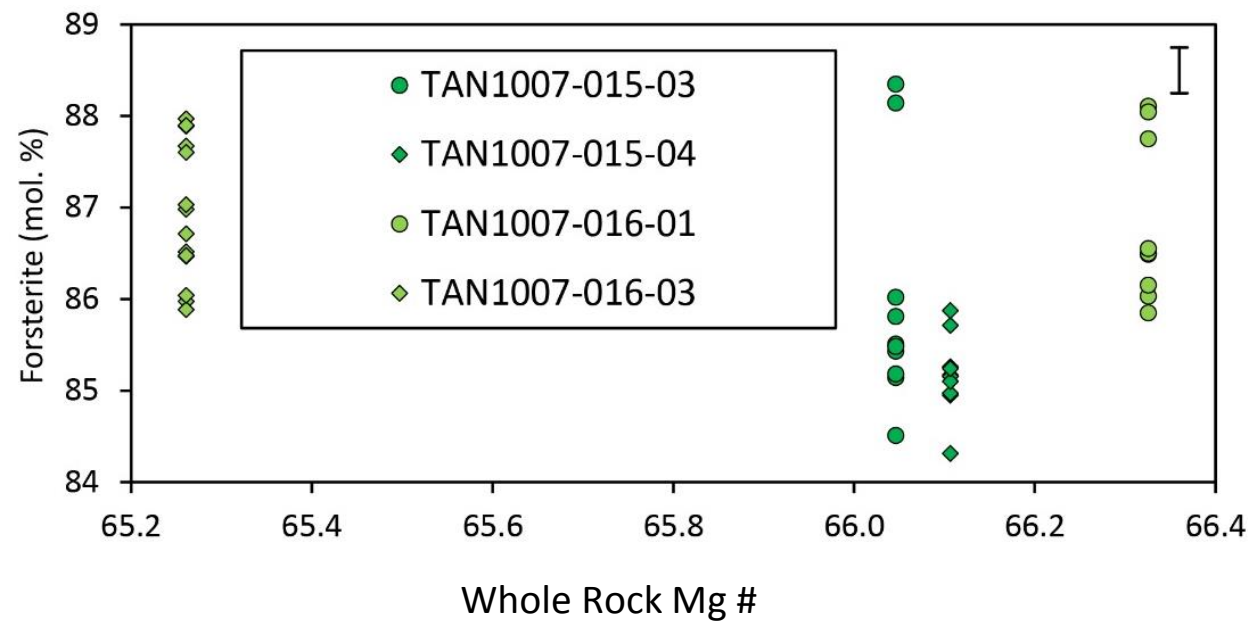

Figure 4.31. Plots showing olivine compositions of samples from Rapuhia Ridge.

Forsterite (Fo) content is plotted against whole rock Mg. Dark green symbols denote analyses of olivine phenocrysts from TAN1007-015 samples, and light green symbols denote analyses of olivine phenocrysts from TAN1007-016 samples. The error bar denotes 2 SD uncertainty estimates based on repeated analyses of olivine standard Springwater Olivine.

\section{Clinopyroxene}

Clinopyroxene phenocrysts from Rapuhia Ridge have similar compositions, varying from $\mathrm{En}_{45-54} \mathrm{Wo}_{35-44} \mathrm{Fs}_{7-17}$ (Figure 4.32). Values of $\mathrm{Mg}$ \# range from 73-87. With increasing $\mathrm{Mg} \#$, all clinopyroxene phenocrysts are characterised by increasing $\mathrm{SiO}_{2}$ and $\mathrm{Cr}_{2} \mathrm{O}_{3}$, and decreasing $\mathrm{Al}_{2} \mathrm{O}_{3}$ and $\mathrm{TiO}_{2}$.

\section{$\underline{\text { Plagioclase }}$}

Plagioclase phenocrysts from Rapuhia Ridge have An contents that range from $\mathrm{An}_{76-91}$, and $\mathrm{K}_{2} \mathrm{O}$ contents that range from $<0.1-0.3 \mathrm{wt} \%$. The two samples from the TAN1007-016 suite generally contain plagioclase with higher An and lower Or contents. All plagioclase analyses appear to follow a similar trend of increasing Or content with decreasing An (Figure 4.32). 
a)

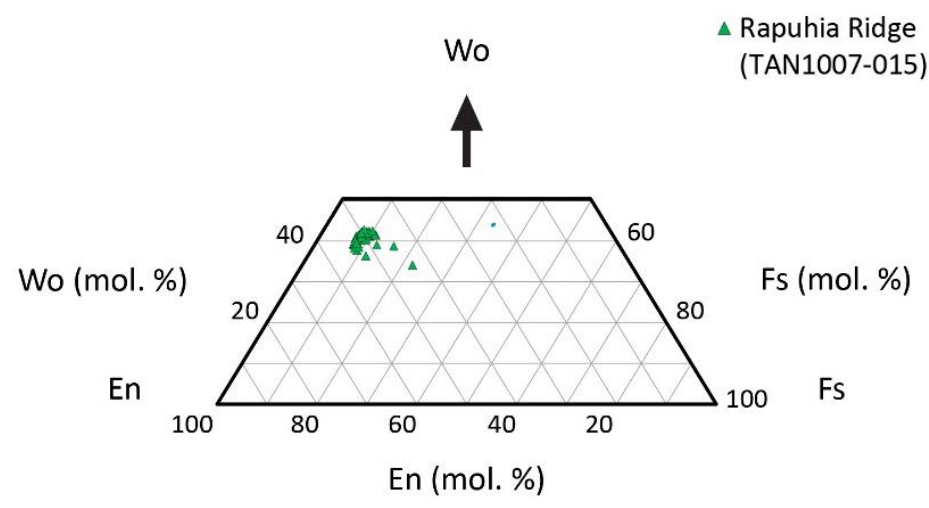

b)
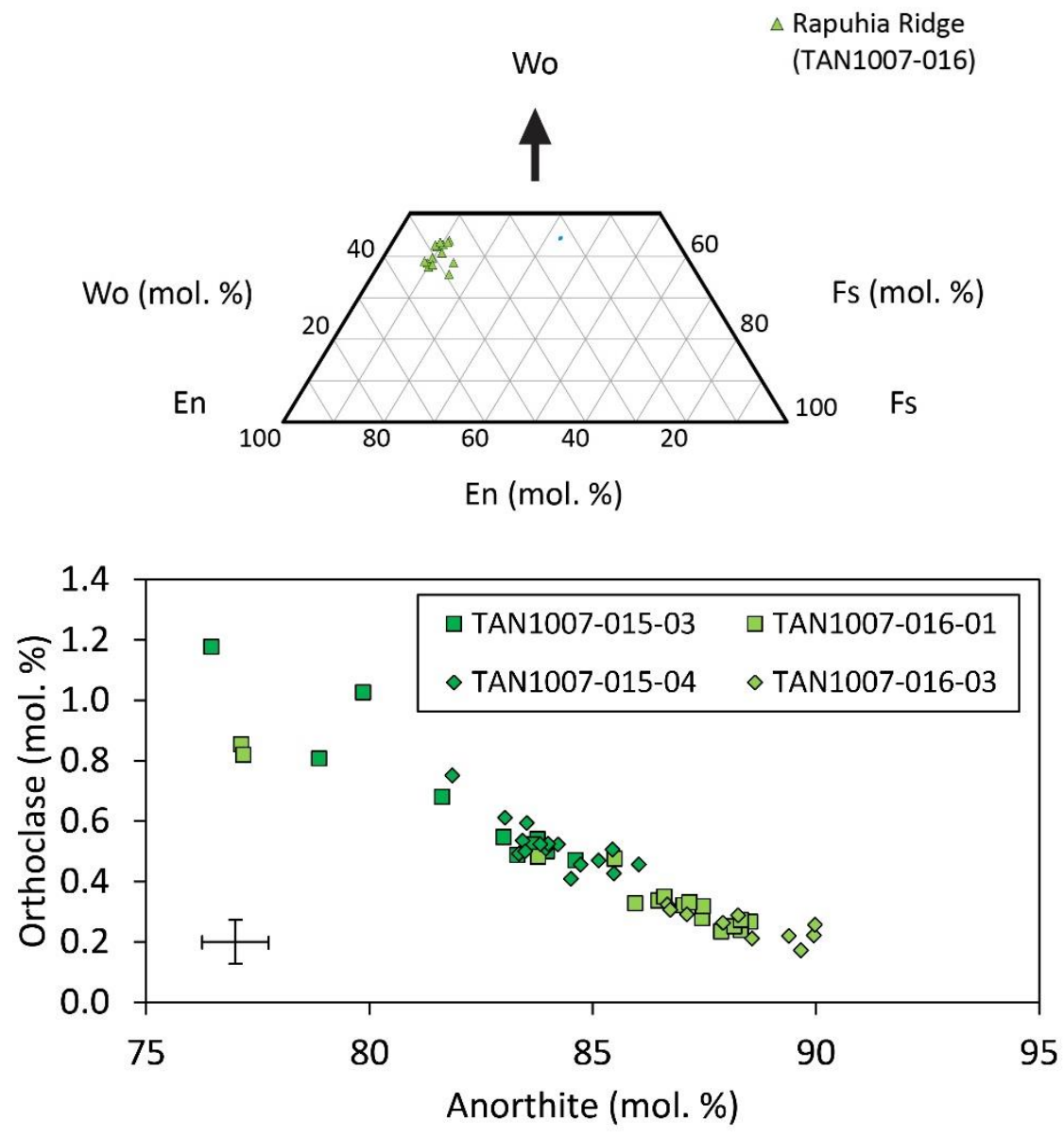

Figure 4.32. Plots of Rapuhia Ridge mineral compositions.

a) Clinopyroxene from TAN1007-015 samples, b) clinopyroxene from TAN1007-016 samples, and c) Orthoclase (Or) versus Anorthite (An) content for plagioclase. Wo, En, and Fs represent Wollastonite, Enstatite and Ferrosilite. The error ellipses in a) and b) denote 2 SD uncertainty estimates based on repeated analyses of clinopyroxene standard Kakanui Augite (En, Wo, Fs). The error bar in c) denotes 2 SD uncertainty estimates based on repeated analyses of plagioclase standard Plagioclase NMNH 115900. 


\subsubsection{Rapuhia Seamount Crystal Chemistry}

\section{Clinopyroxene}

Clinopyroxene phenocryst compositions from TAN1007-014 range from En45${ }_{50} \mathrm{Wo}_{36-42} \mathrm{Fs} 9-17$ (Figure 4.33), although most are restricted to Wo contents of Wo38-39. Values of $\mathrm{Mg} \#$ range from $77-84 . \mathrm{Cr}_{2} \mathrm{O}_{3}$ contents are all $<0.1 \mathrm{wt} \%$.

\section{Plagioclase}

Plagioclase crystals of Rapuhia samples display a wide range of compositions. Crystals from all lavas analysed follow a similar trend with increasing Or content with decreasing An values (Figure 4.5).

TAN0205-101 phenocrysts are characterised by An contents that range from $\mathrm{An}_{41-74}$ (Figure 4.33). Within a given phenocryst, An content may vary by up to 20 mol. \%, but typically varies within 6-10 mol. \% (Figure 4.33). Groundmass plagioclase crystals are characterised by higher Or contents of up to 4 mol. \% (Figure 4.33). Both phenocryst and groundmass phases follow a similar trend of increasing Or content with decreasing mol. \% An (Figure 4.6).

Phenocrysts from the TAN1007-014 samples are characterised by a wide range of An values, between $\mathrm{An}_{46-93}$ in both phenocryst cores and rims. (Figure 4.33). Compared to plagioclase from TAN0205-101 samples, they have higher contents of An, but lower $\mathrm{SiO}_{2}$ and $\mathrm{Na}_{2} \mathrm{O}$ contents. Groundmass crystals have lower An values than the rims and cores of phenocrysts. Zoning is highly variable, with both normal and reverse zoning, where $\mathrm{Ab}$ content may range from $\mathrm{Ab}_{33-16}$ within a single phenocryst.

\section{$\underline{\text { Fe-Ti Oxides }}$}

Both accessory ilmenite and magnetite were analysed in TAN1007-014 samples. Ilmenite crystals are characterised by $\mathrm{TiO}_{2}$ contents of $41-42 \mathrm{wt} \% \mathrm{FeO}_{\text {(tot.) }}{ }^{5}$ contents of 52 - 53 wt \%. Magnetite crystals contain 76 - 78 wt $\% \mathrm{FeO}_{(\text {tot.) }}$ and 11.1 13.0 wt $\% \mathrm{TiO}_{2}$.

${ }^{5} \mathrm{FeO}_{\text {(tot) }}$ is defined as the total sum of $\mathrm{FeO}\left(\mathrm{wt} \%\right.$ ) and $\mathrm{Fe}_{2} \mathrm{O}_{3}$ (wt \%) in a given oxide crystal. 
a)

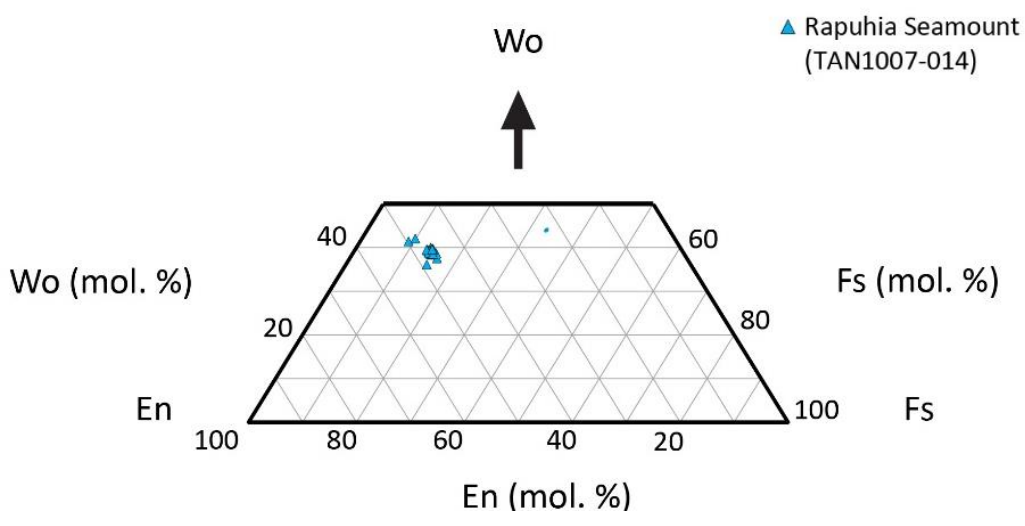

b)

En (mol. \%)

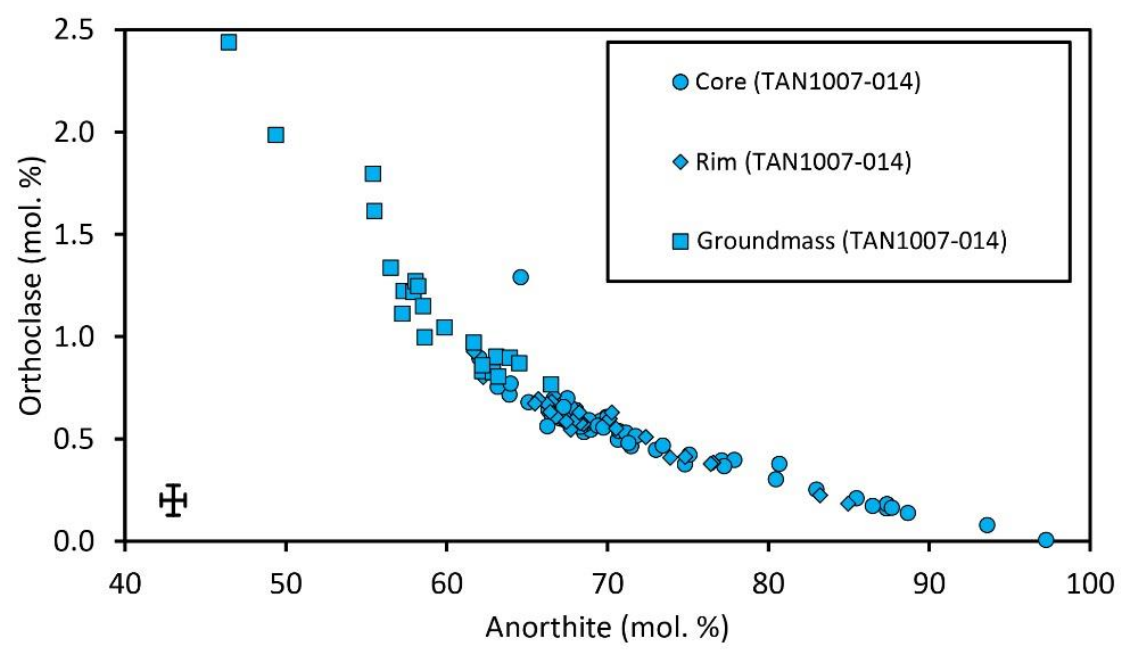

c)

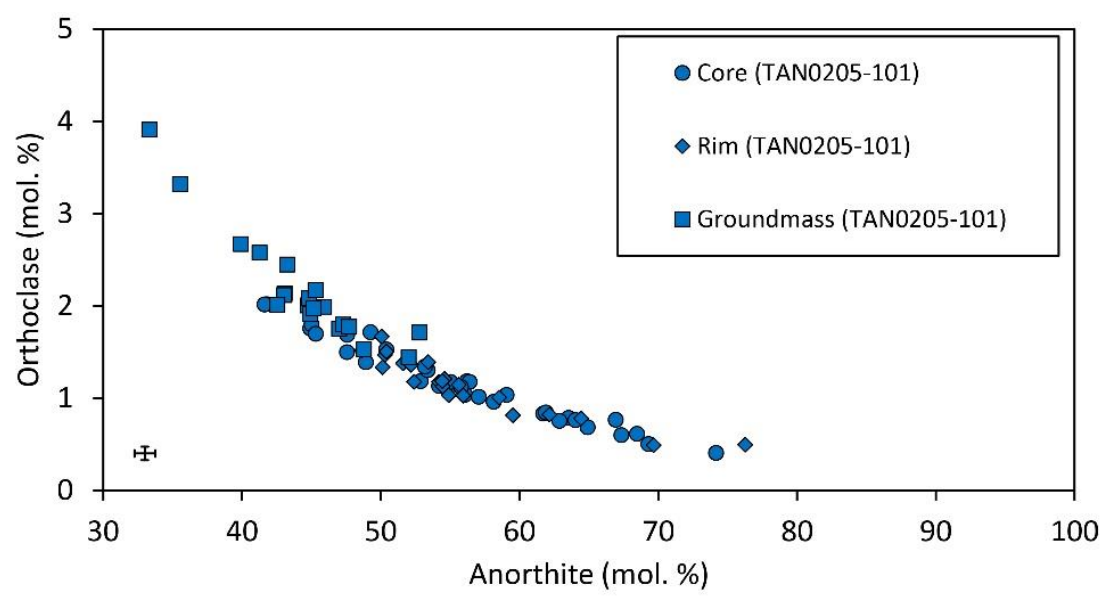

Figure 4.33. Plots showing compositions of clinopyroxene and plagioclase crystals from Rapuhia Seamount.

a) Clinopyroxene from TAN1007-014 samples. Orthoclase (Or) versus Anorthite (An) content of plagioclase is shown in b) from TAN1007-014 samples, and in c) from TAN0205-101 samples. Wo, En and Fs represent Wollastonite, Enstatite and Ferrosilite. The error ellipses in a) and b) denote 2 SD uncertainty estimates based on repeated analyses of clinopyroxene standard Kakanui Augite. The error bar in c) denotes 2 SD uncertainty estimates based on repeated analyses of plagioclase standard Plagioclase NMNH 115900. 


\section{$\underline{\text { Amphibole }}$}

Compositions of amphibole phenocrysts analysed in TAN0205 samples were classified using the excel spreadsheet of Locock (2014), which follows the 2012 classification scheme outlined in Hawthorne et al. (2012). Compositions include magnesio-ferri-hornblende, Ti-rich magnesio-hastingsite, and Ti-rich ferrisadanagaite. Cores and rims overlap in all compositional groups.

\subsubsection{Giljanes Seamount Crystal Chemistry}

\section{Plagioclase}

Plagioclase phenocrysts from sample TAN0205-100-03 are characterised by anorthite contents of An63-94, and orthoclase contents that range from $<0.1-1.7$ mol. $\%$ (Figure 4.34). Phenocrysts may show minimal variation between core and rim compositions, but may also be characterised by variations in An content of over 10 mol. \% An. Compositions of core and rims follow similar trends of increasing mol \% Or with decreasing An content (Figure 4.34).

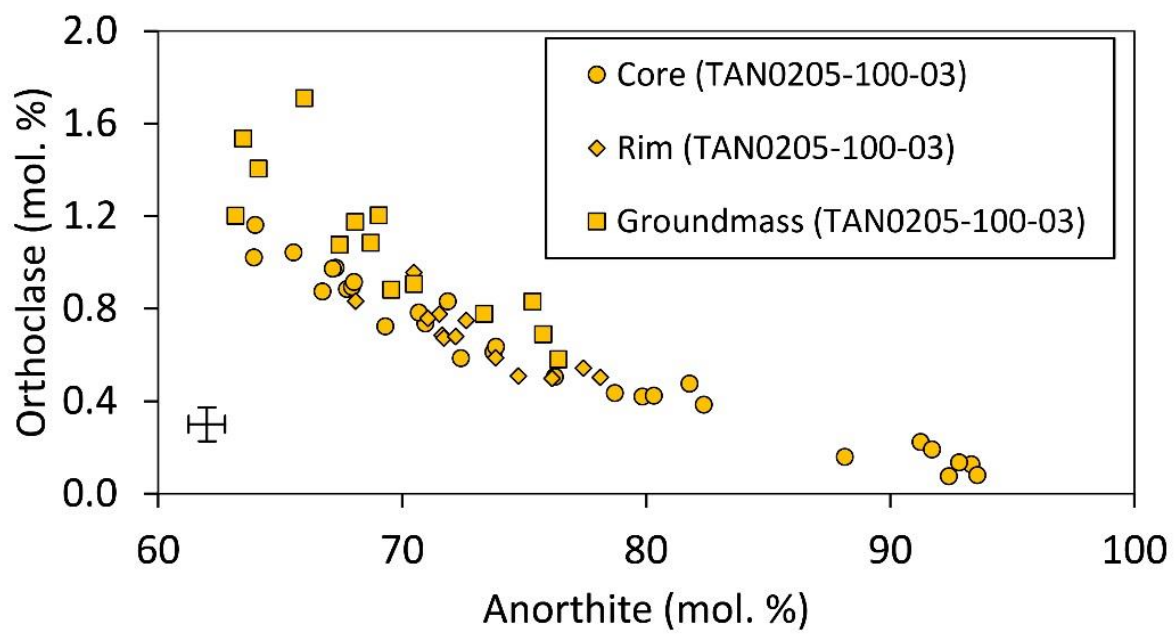

Figure 4.34. Plot of Orthoclase (mol. \%) against Anorthite (mol. \%) for plagioclase from sample TAN0205-10003 from Giljanes Seamount.

The error bar denotes 2 SD uncertainty estimates based on repeated analyses of plagioclase standard Plagioclase NMNH 115900. 


\subsection{Calculated Intensive Variables and Equilibrium Results}

A series of calibrations have been applied in this study in order to gain insight into crystallisation conditions, such as temperature, pressure and oxygen fugacity, associated with different back-arc volcano magmas. Thermometers and barometers were selected on the basis of the mineral assemblage for a given lava. When possible, multiple methods were used for each sample to evaluate the credibility of calculated conditions, as well as assessing the suitability of each method.

\subsubsection{Fe-Ti Oxide Thermo-oxybarometry}

Temperature and oxygen fugacity $\left(\mathrm{fO}_{2}\right)$ conditions for TAN1007-014 samples from Rapuhia were estimated from ilmenite and magnetite crystals, using the Fe-Ti oxide thermo-oxybarometers of Sauerzapf et al. (2008) and Ghiorso and Evans (2008). To ensure that selected crystals that were in equilibrium with the host melt, only coexisting Fe-Ti pairs, where crystals either shared a common boundary, or were associated with the same phenocryst, were used for estimating temperature and oxygen fugacity conditions (Blundy and Cashman, 2008). Fe-Ti oxide pairs were also tested for equilibrium using the $\mathrm{Mg} / \mathrm{Mn}$ partitioning test outlined in Bacon and Hirschmann (1988).

Temperature estimates for ilmenite and magnetite crystals in Rapuhia samples range from ca. $938-957^{\circ} \mathrm{C}\left( \pm 13.43{ }^{\circ} \mathrm{C}\right)$ using the thermometer of Ghiorso and Evans (2008), and from ca. $899-915^{\circ} \mathrm{C}\left( \pm 11.07^{\circ} \mathrm{C}\right)$ using the thermometer of Sauerzapf et al. (2008). Values of $\Delta \mathrm{NNO}$ range from +0.93 to $+1.07( \pm 0.09)$. Although temperature estimates from the Sauerzapf et al. (2008) thermometer are consistently lower by $30-40{ }^{\circ} \mathrm{C}$, the Ghiorso and Evans (2008) thermometer has been proven in previous studies to yield reliable temperature estimates (e.g. Blundy and Cashman, 2008), that are consistent with those obtained from other thermometers. The temperature results obtained from the Ghiorso and Evans (2008) thermometer are therefore inferred to represent crystallisation temperatures of ilmenite and magnetite crystals in Rapuhia Seamount. 


\subsubsection{Amphibole Geothermobarometry and Hygrometry}

Compositions of amphibole phenocrysts were used to estimate temperature, pressure and water content of TAN0205-101 dacitic magmas from Rapuhia Seamount. Formulae in the spreadsheet from Ridolfi et al. (2010) were used to determine intensive parameters, where calculations are based solely on the composition of amphibole. Calculated variables span a wide range of values, and range from 783 $976{ }^{\circ} \mathrm{C}\left( \pm 22^{\circ} \mathrm{C}\right)$. Pressure conditions range from $74-353 \mathrm{MPa}( \pm 39 \mathrm{MPa})$, and correspond to depths of $\sim 2.6-12.5 \mathrm{~km}$. $\mathrm{H}_{2} \mathrm{O}$ melt contents range from ca. 4 - $6 \mathrm{wt} \%$ $( \pm 0.9$ wt $\%)$. The higher temperature estimates of amphibole compositions are consistent with estimates obtained from ilmenite and magnetite compositions from TAN1007-014 samples.

The majority of estimates for intensive variables derived from amphibole compositions were obtained from multiple analyses on a given crystal. Many of the amphibole crystals contain different compositional zones that are characterised by large differences in values for pressure, temperature and water contents. The high differences in intensive variables within and between individual crystals can be explained by crystallisation over a wide range of pressures and temperatures.

\section{$4.5{ }^{40} \mathrm{Ar} /{ }^{39} \mathrm{Ar}$ Geochronology Results}

\subsubsection{Evaluation of ${ }^{40} \mathrm{Ar} /{ }^{39} \mathrm{Ar}$ Isotopic Analyses}

Sample ages were determined by Andrew Calvert and Graham Leonard at the USGS Geochronology Laboratory in Menlo Park, California. Results obtained from each analysis are shown in (Figure 4.9). For each sample, total gas ages, weighted mean plateau ages (WMPA), and isochron ages were determined. Total gas ages were determined from the sum of all radiogenic ${ }^{40} \mathrm{Ar}$ and ${ }^{39} \mathrm{Ar}$ produced from each heating step. WMPA are defined by Calvert et al. (2005) as ages where at least $50 \%$ of ${ }^{39} \mathrm{Ar}$ released is within $\pm 2 \sigma$ error. Isochron diagrams are plotted with ${ }^{40} \mathrm{Ar} /{ }^{36} \mathrm{Ar}$ against ${ }^{39} \mathrm{Ar} /{ }^{36} \mathrm{Ar}$, using the regression line of York (1968). A mean square of weighted deviates (MSWD) was calculated to estimate goodness of fit for each age. 

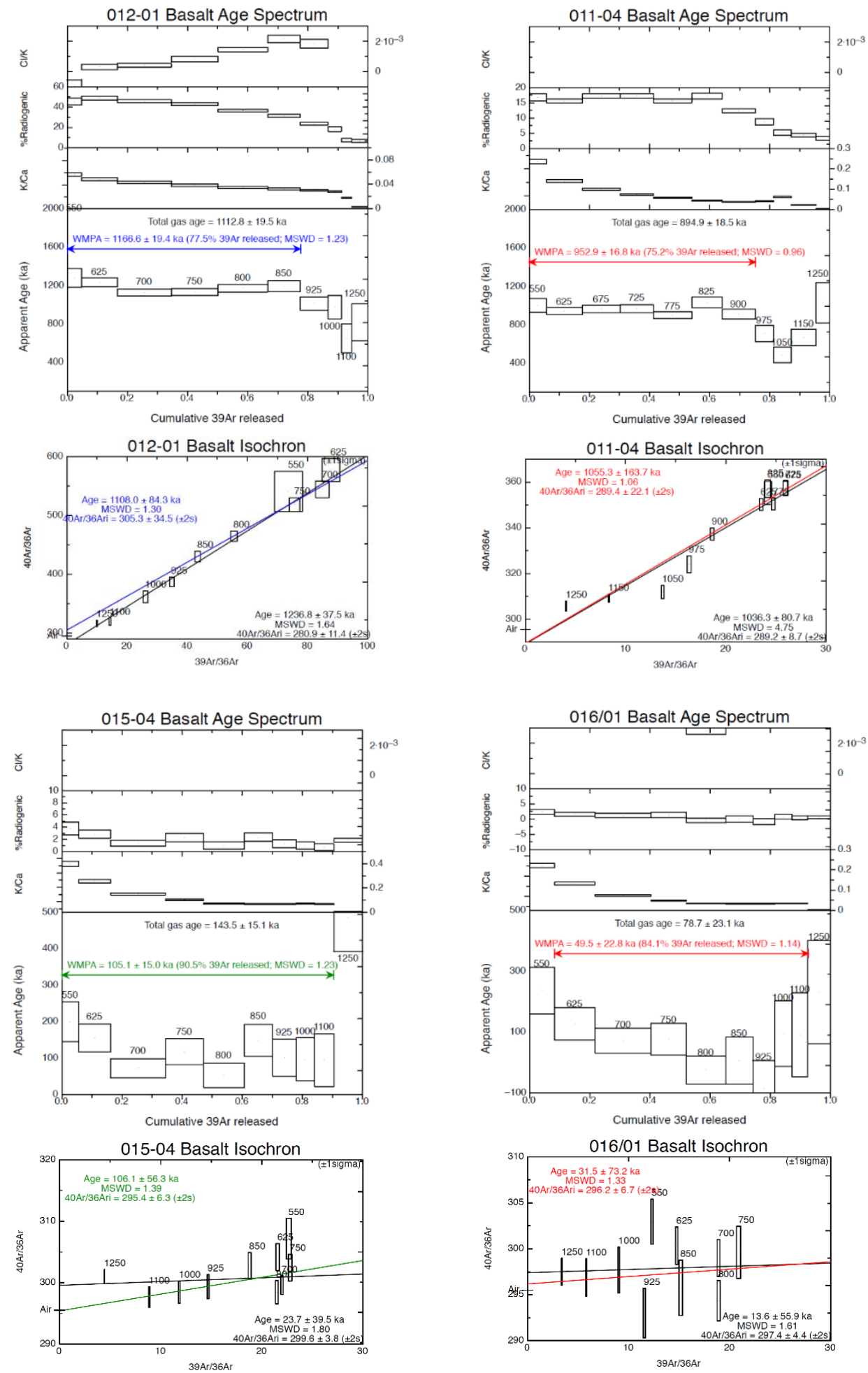

Figure 4.35. Plots of age spectra and isochron diagrams for a) TAN1007-012-01, b) TAN1007-011-04, c) TAN1007-015-04, and d) TAN1007-016-01.

Age spectra plots show values of $\mathrm{Cl} / \mathrm{K}$, radiogenic ${ }^{39} \mathrm{Ar} \%, \mathrm{~K} / \mathrm{Ca}$ and apparent age plotted against cumulative ${ }^{39} \mathrm{Ar}$ released during analysis. Coloured lines and text correspond to WMPA and isochron ages. Ages in black represent total gas ages. Plots courtesy of Leonard and Calvert, pers. comms. (2015). 


\subsection{2 ${ }^{40} \mathrm{Ar} /{ }^{39} \mathrm{Ar}$ Geochronology of Gill Seamount and Rapuhia Ridge}

Samples selected for radiometric ${ }^{40} \mathrm{Ar} /{ }^{39} \mathrm{Ar}$ isotope dating were from two volcanoes: Gill Seamount and Rapuhia Ridge. The ${ }^{40} \mathrm{Ar} /{ }^{39} \mathrm{Ar}$ isotope ages of the backarc samples range from $1166.6 \pm 19.4 \mathrm{ka}$ to $849.4 \pm 16.8 \mathrm{ka}$ for Gill Seamount, and $105 \pm 15.0 \mathrm{ka}$ to $49.5 \pm 22.8 \mathrm{ka}$ for Rapuhia Ridge (Figure 4.35 ). The age results from each volcano are listed in order of oldest to youngest. Preferred ages and errors, as well as the number of incremental heating steps for each sample, are listed in Table 4.2 .

\begin{tabular}{|c|c|c|c|c|c|c|c|}
\hline Sample & Location & $\begin{array}{l}\text { Total } \\
\text { Steps } \\
\end{array}$ & $\%{ }^{39} \mathrm{Ar}$ & $\begin{array}{c}\text { WMPA } \\
\text { (ka) }\end{array}$ & $\begin{array}{c}\text { Error } \\
\text { (ka) }\end{array}$ & MSWD & $\begin{array}{c}\text { Age range } \\
( \pm 2 \sigma \text { error })\end{array}$ \\
\hline TAN1007-012-01 & Gill Seamount & 10 & 77.5 & 1166.6 & 19.4 & 1.23 & $1128-1205$ \\
\hline TAN1007-011-04 & Gill Seamount & 11 & 75.2 & 952.9 & 16.8 & 0.96 & $919-987$ \\
\hline TAN1007-015-04 & Rapuhia Ridge & 10 & 90.5 & 105.1 & 15 & 1.23 & $75-135$ \\
\hline TAN1007-016-01 & Rapuhia Ridge & 10 & 84.1 & 49.5 & 22.8 & 1.14 & $4-95$ \\
\hline
\end{tabular}

Table 4.2. Ages and Uncertainties obtained for each sample selected for ${ }^{40} \mathrm{Ar} /{ }^{39} \mathrm{Ar}$ isotope analysis

\subsubsection{Geochronology of Gill Seamount}

\section{$\underline{\text { TAN1007-012-01 }}$}

Apparent age spectra from sample TAN1007-012-01 display a relatively flat plateau for the first six heating steps $\left(550-850^{\circ} \mathrm{C}\right)$, but display younger ages from the final four heating steps $\left(850-1250^{\circ} \mathrm{C}\right)$. The radiogenic yields are also lower for these final steps, and the associated apparent ages were interpreted as unreliable. For the first six steps, apparent ages were interpreted as reliable, and were used to obtain a WMPA of $1166.6 \pm 19.4 \mathrm{ka}(2 \sigma)$, with $77.5 \%$ of radiogenic argon released. An isochron was plotted using the plateau ages, and gave an age of $1108 \pm 84.3 \mathrm{ka}$, within $\pm 1 \sigma$ error of the WMPA age. The WMPA of $1166.6 \pm 19.4 \mathrm{ka}$ is the preferred age for the sample.

\section{$\underline{\text { TAN1007-011-04 }}$}

Sample TAN1007-011-04 displays a similar age pattern to that that TAN1007-012-01, where the apparent ages associated with the first seven steps (550 - $\left.900^{\circ} \mathrm{C}\right)$ and final step $\left(1250^{\circ} \mathrm{C}\right)$ display a similar apparent ages and are within $\pm 1 \sigma$ error, and are progressively lower for the three heating steps within the $975-1150^{\circ} \mathrm{C}$ 
range. These heating steps are also associated with relatively low radiogenic yields compared to the earlier heating steps, and are interpreted as not representative of crystallisation ages. A WMPA of $952.9 \pm 16.8 \mathrm{ka}$ was calculated using the apparent ages obtained from the first seven heating steps, with $75.2 \%$ of radiogenic argon released. An isochron was plotted using the plateau ages, and an age of $1055.3 \pm 163.7$ ka was obtained, which is within $\pm 1 \sigma$ error of the WMPA age, but has a large uncertainty. The WMPA of $952.9 \pm 16.8 \mathrm{ka}$ is the preferred age for the sample.

\subsubsection{Geochronology of Rapuhia Ridge}

\section{TAN1007-015-04}

A WMPA of 105.1 $\pm 15.0 \mathrm{ka}$ was obtained from sample TAN1007-015-04, using apparent ages from the first nine heating steps, which represented $90.5 \%$ of the radiogenic argon that was released. The apparent age spectra from these steps however, had an undulating pattern, where some steps were not within $\pm 1 \sigma$ error, although they were within $\pm 2 \sigma$ error. The apparent age of the final heating step is discordant with the WMPA from the earlier heating steps, and is associated with a minimal $\mathrm{K} / \mathrm{Ca}$ ratio. This is not considered to be a reliable age. Using the first nine steps, an isochron age of $106.1 \pm 56.3 \mathrm{ka}$ was obtained, which is concordant with the plateau age obtained, but has a large uncertainty. The WMPA of $105.1 \pm 15.0 \mathrm{ka}$ is the preferred age of crystallisation for the sample.

\section{$\underline{\text { TAN1007-016-01 }}$}

Sample TAN1007-016-01 yielded a U-shaped age spectrum, with a plateau age of $49.5 \pm 22.8 \mathrm{ka}$, using apparent ages from the middle 8 heating steps $\left(625-1100^{\circ} \mathrm{C}\right)$, which accounted for $84.1 \%$ of the total released radiogenic argon. Apparent ages obtained from the first and last heating steps appear anomalously high compared with the middle ages, and were excluded from the crystallisation age. Apparent ages from the middle heating steps were not within $\pm 1 \sigma$ error, but were within $\pm 2 \sigma$ error. An isochron was plotted using the plateau ages, and an age of $31.5 \pm 73.2 \mathrm{ka}$ was obtained. This age is concordant with the WMPA, but is associated with a higher uncertainty. The WMPA of $49.5 \pm 22.8 \mathrm{ka}$ is the preferred age for this sample. 


\section{Chapter 5: Discussion}


The primary objective of this study is to investigate the origin and evolution of back-arc stratovolcanoes in the southern KAHT. Since they were only discovered in recent years (Rapuhia Seamount, Rapuhia Ridge, Yokosuka Seamount and Giljanes Seamount in 2002: Wright et al., (2006), Gill Seamount in 2006: Wysoczanski et al., (2010)), their ages and compositions are not well-known in detail. A wide number of studies undertaken on back-arc volcanoes and cross-arc volcanic chains in intraoceanic settings has revealed that they can be associated with subduction concurrent with arc-front volcanism (e.g. Izu-Bonin Arc: Hochstaedter et al., (2001), Tollstrup et al. (2010), Machida et al., (2008), Mariana Arc: Stern et al. (1993), Pearce et al., (2005), Tollstrup and Gill, (2005), Stern et al., (2006), Kamchatka subduction zone: Duggen et al., (2007), Kermadec Arc, Todd et al., (2010, 2011)). This study presents the first detailed geochemical dataset of back-arc stratovolcanoes in the southern KAHT, and new insights regarding the magmatic and mantle processes associated with each back-arc volcano are obtained. Data obtained from ${ }^{40} \mathrm{Ar} /{ }^{39} \mathrm{Ar}$ isotope geochronology place new constraints on the timing of magmatism associated with back-arc volcanism in the southern Havre Trough. In situ mineral compositions provide new information on the range of magmatic processes associated with each individual volcano. Whole rock major element and trace element compositions elucidate processes that drive the magmatic evolution and subduction-related processes associated with each back-arc stratovolcano. The implications from backarc volcano compositions for the nature of the mantle wedge in the southern Havre Trough are also examined.

\subsection{Constraints from ${ }^{40} \mathrm{Ar} /{ }^{39} \mathrm{Ar}$ Ages}

As mentioned previously, Wysoczanski et al. (2010) found that back-arc stratovolcanoes, cross-arc chains and deep rifts in the southern Havre Trough are all characterised by high backscatter reflectivity. This reflectivity pattern is comparable to that shown in areas of recent magmatism in the Izu-Bonin Arc, which led them to suggest that the southern Havre Trough may also comprise back-arc volcanoes and ridges that are associated with recent volcanism. Todd et al. (2010) demonstrated that compositions of Rumble V Ridge lavas can be explained by recent magmatism derived 
by partial melts modified by subduction that is coeval with volcanism at the Kermadec arc volcanic-front.

The oldest age associated with Gill Seamount was obtained from a basalt dredged from the summit (TAN1007-012-01), and an age of $1166.6 \mathrm{ka}$ was obtained. An age of $952.9 \mathrm{ka}$ was obtained from a basalt dredged from the flank of Gill Seamount (TAN1007-011-04). This represents the minimum age for volcanism associated with Gill Seamount. Ages obtained from both samples do not show any evidence for overlapping in either isochron ages or plateau ages (Section 4.5). Both samples are also differ in whole rock compositions, and are characterised by distinct plagioclase compositions (Section 4.3), which indicates that both lavas originated from different melts during different time intervals. Both ages constrain a time interval for volcanism associated with Gill Seamount to be within ca. $952.9-1166.6 \mathrm{ka}( \pm$ $16.8-19.4 \mathrm{ka})$.

The two ages obtained from Rapuhia Ridge also appear distinct from one another. An age of $105.1 \mathrm{ka}$ was obtained from the TAN1007-015 suite (Sample TAN1007-015-04), and an age of 49.5 ka was obtained from the TAN1007-016 suite (Sample TAN1007-016-01). Isochron ages obtained are associated with high standard errors, and could suggest that both eruptions are coeval. However, samples from the TAN1007-015 suite are characterised by higher trace element concentrations (Section 4.2), and groundmass plagioclase with generally lower An contents (Section 4.3). This indicates that sample TAN1007-016-01 is associated with distinct, most likely younger volcanism. The young ages obtained support previous interpretations that Rapuhia Ridge was associated with recent magmatism (e.g. Wright et al., 2006).

The ages obtained from back-arc volcano lavas in the southern KAHT are significantly younger than any known age of magmatism associated with the Colville Arc, where the youngest reported age is 5.4 Ma (Adams et al., 1994). The 0.9-1.2 Ma period for volcanism associated with Gill is comparable to ages obtained from Rumble V cross-chain basalts (<2 Ma: Gamble et al., 2009; Todd et al., 2010). Ages obtained from Kermadec arc-front lavas are <2 Ma (e.g. Lloyd and Nathan, 1981, Turner et al., 1997, Christie, 2000; Mortimer et al., 2010). The ${ }^{40} \mathrm{Ar} /{ }^{39} \mathrm{Ar}$ ages obtained from the back-arc stratovolcanoes in the southern Havre Trough are thus comparable to known ages associated with the Rumble $\mathrm{V}$ cross-chain and arc-front volcanoes, and these 
volcanic features can be inferred to reflect recent magmatism associated with the present-day subduction driving volcanism at the Kermadec Arc-front.

A major limitation associated with currently proposed models for the timing and evolution of intra-oceanic arc-back-arc systems in the SW Pacific region, such as the southern KAHT, is the lack of reported absolute age data. Mortimer et al. (2010) proposed that arc magmatism in the SW Pacific region was active during distinct and separate time intervals. They suggested that volcanism associated with the Kermadec Arc and Taupo Volcanic Zone are associated with a currently active phase of subduction zone magmatism that initiated in the Quaternary. The oldest volcanic rocks dated from the TVZ and Kermadec Arc are Quaternary in age (Lloyd and Nathan, 1981; Wilson et al., 1995; Mortimer et al., 2010).

The ${ }^{40} \mathrm{Ar} /{ }^{39} \mathrm{Ar}$ ages obtained from back-arc stratovolcanoes here are consistent with the model proposed by (Mortimer et al., 2010), and can be considered to be associated with the same period of subduction zone magmatism as the Kermadec Arc and Taupo Volcanic Zone. Although back-arc stratovolcanoes in the southern Havre Trough are coeval with Kermadec arc-front volcanoes, their rear-arc setting suggests that they originate from fundamentally different magmatic and mantle-related processes. These processes are explored in detail, and form the remainder of the discussion.

\subsection{Effects of Alteration}

A major challenge of this study was that some of the samples analysed showed evidence for alteration. This makes reconciling magmatic processes using bulk-rock compositions of affected samples inherently difficult. All the samples analysed from the summit of Gill Seamount (Dredge TAN1007-012) were characterised by variable contents of amygdales, and were subject to pervasive infiltration by secondary clays/minerals. These samples are characterised by elevated contents of $\mathrm{P}_{2} \mathrm{O}_{5}$ (Figure 4.18), and values of L.O.I. >1.0 wt \%, and are $>5.0 \mathrm{wt} \%$ for the most affected samples. When compared with flank samples, TAN1007-012 lavas are characterised by elevated concentrations in $\mathrm{U}$ and $\mathrm{Pb}$, and display relatively high scatter in LILE concentrations. Enrichments in LILE are markedly lower than those observed in flank samples, which suggests that these elements (e.g. $\mathrm{Cs}, \mathrm{Rb}$ ) were affected by secondary alteration. Thus, 
magmatic and mantle processes associated with Gill Seamount were examined only using major oxide and trace element cocentrations from relatively fresh unaltered samples from the flank lava suite (TAN1007-011).

Petrographic examination of the summit samples indicated that their mineral phases were not affected by alteration. Mineral compositions analysed by EMPA were therefore regarded to be representative of magmatic and crystallisation processes associated with TAN1007-012 lavas, and have subsequently been included for interpretation.

Elevated contents of L.O.I. are also observed in samples from Yokosuka Seamount and in some of the western Havre Trough BABB analyses. Sample TAN1513-041-01 is characterised by LOI contents $>4 \mathrm{wt} \%$, and elevated concentrations in $\mathrm{Cs}$ and $\mathrm{Li}$ (Section 4.2). Sample TAN0205-102-03 is also characterised by elevated concentrations in Li (Figure 4.22). These trace element enrichments could reflect secondary alteration. However, all analyses from Yokosuka and the western Havre Trough BABB have been included in this study, since only a few samples have been collected and analysed from these locations.

\subsection{Magmatic Processes for Back-Arc Volcanoes in the Southern Kermadec Arc}

\subsubsection{Clues from Mineral Compositions}

\subsubsection{Crystallisation Conditions for Basaltic Magmas}

Compositions of olivine and clinopyroxene phenocrysts from Gill and Rapuhia Ridge display trends that reflect fractional crystallisation of these mineral phases. Clinopyroxene phenocrysts display trends of increasing wt $\% \mathrm{TiO}_{2}$ and wt $\% \mathrm{Al}_{2} \mathrm{O}_{3}$, with decreasing Mg \# (Figure 5.1). This is consistent with olivine and clinopyroxene as the predominant crystallising phases, since $\mathrm{Al}$ and $\mathrm{Ti}$ are both incompatible in olivine and clinopyroxene. 
a)

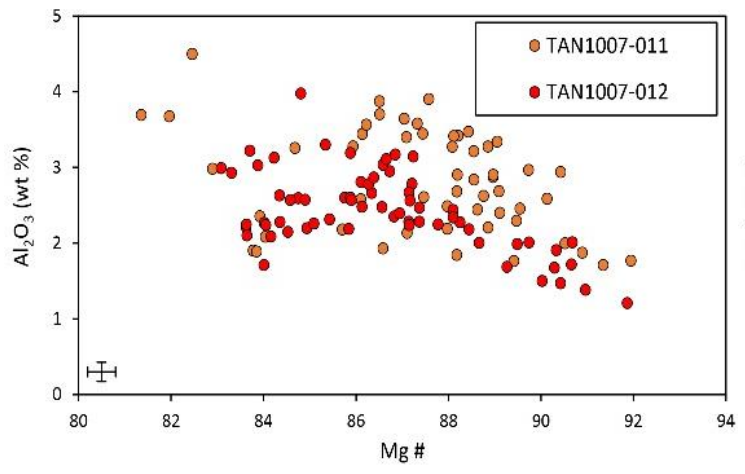

c)

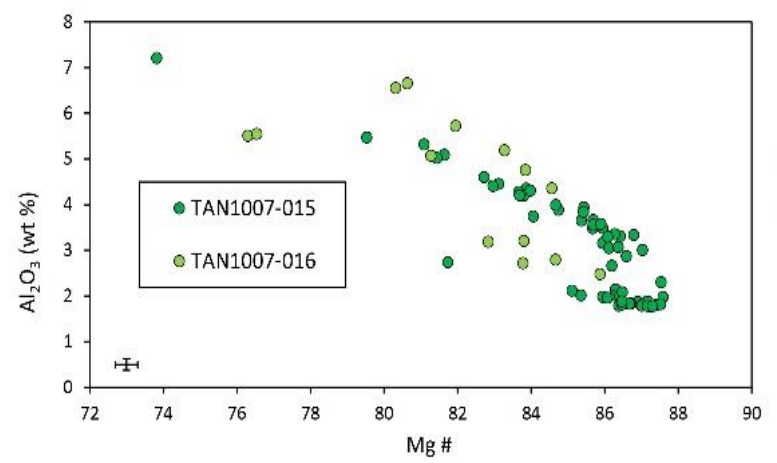

b)

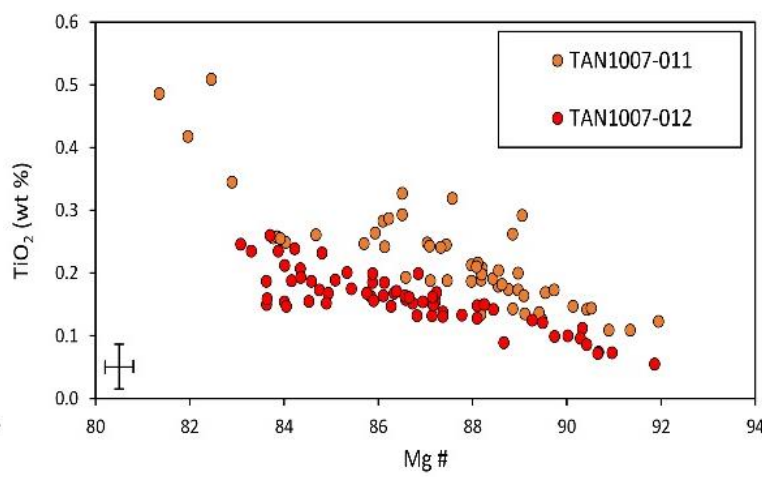

d)

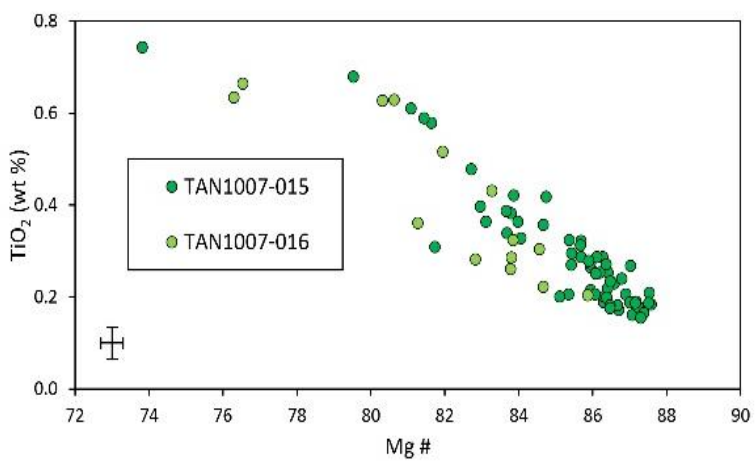

Figure 5.1. Plots of clinopyroxene compositions from Gill Seamount and Rapuhia Ridge.

a) and b) are for Gill Seamount. Red symbols denote TAN1007-012 analyses, and orange symbols denote TAN1007-011 analyses. c) and d) are for Rapuhia Ridge. Dark green symbols denote TAN1007-015 analyses, and light green symbols denote TAN1007-016 analyses. a) and c) show $\mathrm{Al}_{2} \mathrm{O}_{3}$ (wt \%) versus $\mathrm{Mg} \#$, and b) and d) show $\mathrm{TiO}_{2}$ (wt \%) versus $\mathrm{Mg}$ \#. In each plot, the error bars denote $2 \mathrm{SD}$ uncertainty estimates based on repeated analyses of clinopyroxene standard Kakanui Augite.

In order to determine whether olivine phenocrysts were in equilibrium with the host melt at the time of crystallisation, the olivine-liquid equilibria test of Roeder and Emslie (1970) was applied to crystals that were analysed from Gill Seamount and Rapuhia Ridge. Figure 5.2 shows the effect of olivine accumulation on whole rock compositions of lavas from Gill Seamount (Samples TAN1007-011-02) and Rapuhia Ridge (TAN1007-015-03, 04). Olivine phenocrysts from these samples are characterised by Fo contents that are lower than those predicted to be in equilibrium with the whole rock $\mathrm{Mg} \#$, and therefore crystallised from different partial melts. Their wide range in Fo contents could indicate that different olivine populations were incorporated into the melt at different depths during magma evolution and ascent. 


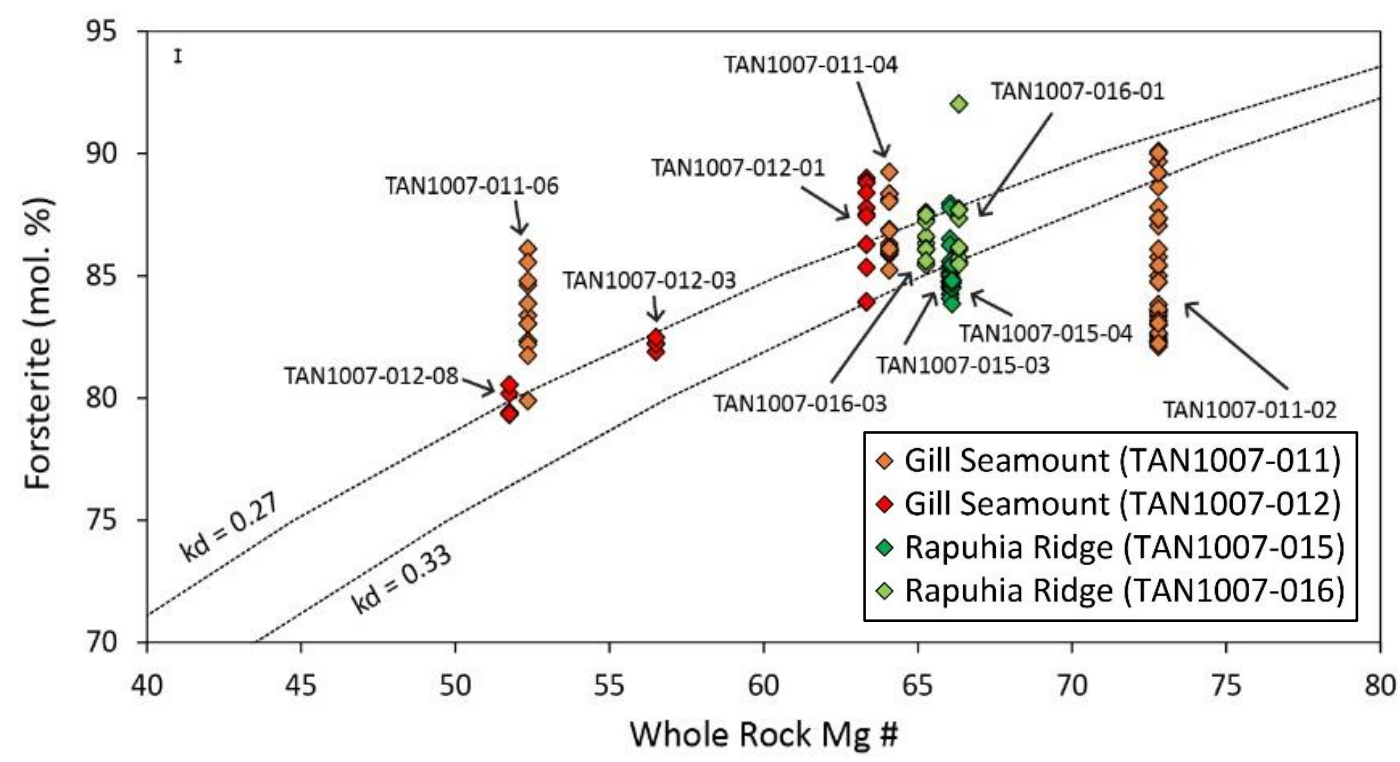

Figure 5.2. Plot showing compositions of olivine crystals in chemical equilibrium with the host melt, and accumulation for olivine phenocrysts, from Gill Seamount and Rapuhia Ridge.

Olivine forsterite (Fo) content is plotted against the whole rock $\mathrm{Mg}$ \# for each volcano. The dashed lines correspond to the maximum and minimum uncertainty for olivine crystals forming in chemical equilibrium in the host melt, based on the olivine-liquid equilibria test of Roeder and Emslie (1970). The error bar denotes 2 SD uncertainty estimates based on repeated analyses of olivine standard Springwater Olivine.

Several of the olivine phenocrysts from Gill Seamount and Rapuhia Ridge, however, have Fo contents that are in equilibrium with the whole rock $\mathrm{Mg} \#$. Thus, these compositions can be used to constrain crystallisation conditions associated with each back-arc volcano.

The olivine phenocrysts that crystallised in equilibrium with their respective melts are characterised by high Fo contents (Table 5.1), which indicates that they crystallised at relatively high temperatures (Figure 5.2). Although accurate temperatures are difficult to constrain without pressure or $\mathrm{H}_{2} \mathrm{O}$ estimates, temperature estimates can be obtained using the Fo-temperature linear regression equation of Sobolev and Danyushevsky (1994). Using their equation, temperature estimates obtained from olivine phenocrysts range from $1136-1155^{\circ} \mathrm{C}\left( \pm 5.78{ }^{\circ} \mathrm{C}\right)$ for Gill Seamount, and $1146-1154{ }^{\circ} \mathrm{C}\left( \pm 21.22{ }^{\circ} \mathrm{C}\right)$ for Rapuhia Ridge (Table 5.1). These values reflect crystallisation conditions that correspond to mid- to upper- crustal levels. 


\section{Sample Volcano Range in Forsterite Content for}

Crystals in Chemical Equilibrium

\begin{tabular}{lll}
\hline TAN1007-011-02 & Gill Seamount & $88.99-90.41$ \\
TAN1007-011-04 & Gill Seamount & $85.67-86.71$ \\
TAN1007-011-06 & Gill Seamount & 80.35 \\
TAN1007-012-01 & Gill Seamount & $83.93-86.29$ \\
TAN1007-012-03 & Gill Seamount & $81.89-82.49$ \\
TAN1007-012-08 & Gill Seamount & $79.33-79.42$ \\
TAN1007-015-03 & Rapuhia Ridge & $85.48-86.87$ \\
TAN1007-015-04 & Rapuhia Ridge & $85.71-85.87$ \\
TAN1007-016-01 & Rapuhia Ridge & $85.85-87.75$ \\
TAN1007-016-03 & Rapuhia Ridge & $85.89-87.03$
\end{tabular}

Table 5.1. Range of Forsterite content of olivine phenocrysts that crystallised in equilibrium with the host melt from each sample from Gill Seamount and Rapuhia Ridge shown in Figure 5.2.

Estimates of melt entrapment pressures can potentially be obtained from melts trapped as inclusions within the olivine crystals. As EPMA analyses were undertaken on olivine crystals that were located in the interior of whole rock samples as opposed to quenched pillow rims, any entrapped olivine-hosted melt inclusions are more likely to have crystallised (e.g. Wysoczanski et al, 2012). Unfortunately, no melt inclusions were observed in any olivine phenocrysts in the samples during energy dispersive spectrometry (EDS) surveys, limiting the ability to obtain more detailed constraints on magma chamber pressures and temperatures.

\begin{tabular}{|c|c|c|c|c|c|}
\hline \multirow[t]{2}{*}{ Sample } & \multirow[t]{2}{*}{ Volcano } & \multicolumn{4}{|c|}{ Temperature Range $\left({ }^{\circ} \mathrm{C}\right)$} \\
\hline & & $n$ & Average & Range & $2 \sigma$ \\
\hline TAN1007-011-04 & Gill Seamount & 6 & 1149.42 & $1136-1155$ & 5.78 \\
\hline TAN1007-016-03 & Rapuhia Ridge & 6 & 1145.76 & $1146-1154$ & 21.22 \\
\hline
\end{tabular}
and Danyushevsky (1994). 


\subsubsection{Rapuhia Seamount Geothermobarometry}

Several intensive parameters can be estimated from compositions of amphibole and Fe-Ti oxide crystals in Rapuhia Seamount lavas. Temperature estimates obtained from both single amphibole and Fe-Ti oxide pair thermometers are generally consistent, with temperature estimates ranging between $938-957{ }^{\circ} \mathrm{C}$ from Fe-Ti oxide pairs, and $976{ }^{\circ} \mathrm{C}$ for the highest temperature estimates obtained from amphibole phenocrysts. The higher temperature values from amphibole crystals are associated with depths of ca. 10.2 - $12.0 \mathrm{~km}$, which represent mid- to upper- crustal levels (Figure 5.3).

Values for pressure, temperature and oxygen fugacity obtained from amphibole crystals are highly variable and likely reflect crystallisation over a wide range of conditions. Given that the cores and rims follow linear compositional trends, amphibole was likely in equilibrium with the melt at the time of crystallisation. The high variation in composition, and in resulting pressure and temperature estimates, observed between cores and rims can be explained by a thermally and/or compositionally stratified magma chamber, where amphiboles crystallise at different depths during magma ascent.

a)

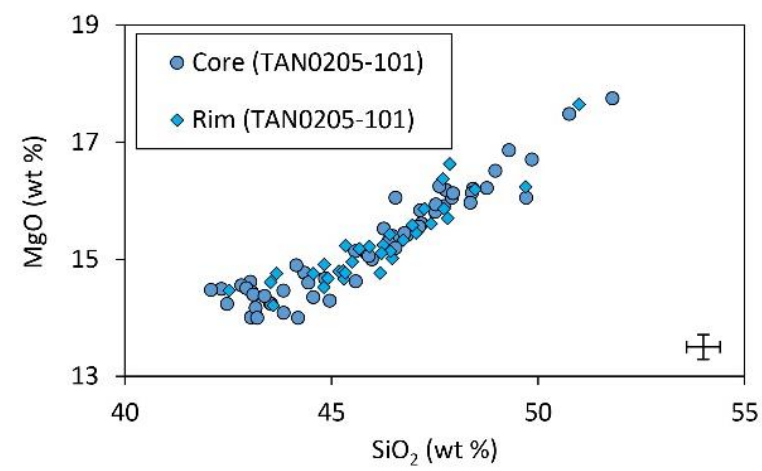

b)

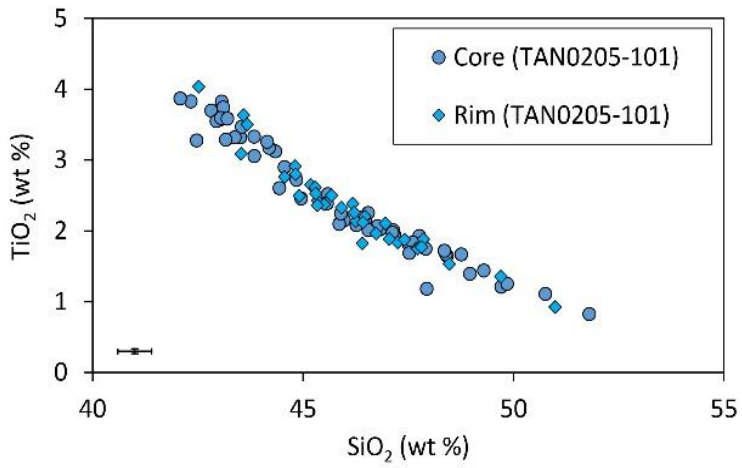

Figure 5.3. Plots of a) $\mathrm{MgO}$ and b) $\mathrm{TiO}_{2}$ versus $\mathrm{SiO}_{2}$ for compositions of amphibole crystals from Rapuhia Seamount, dredge TAN0205-101.

The error bars denote 2 SD uncertainty estimates based on repeated analyses of the amphibole standard Engels amphibole. 


\subsubsection{Plagioclase Compositions}

For any given lava suite, compositions of plagioclase crystals shown are characterised by single trends of increasing Or content with decreasing An content (Figure 5.4; see also section 4.3). These are most simply explained by plagioclase crystallisation from a single melt for each lava suite, where variations in An content reflects crystallisation of plagioclase during different stages of magma differentiation. For each lava suite, plots of An and Or include plagioclase compositions from analyses of both phenocryst cores and rims, as well as late-stage crystallising groundmass (Figure 5.4). Since both the groundmass and phenocrysts follow a similar trend for a given lava suite, this suggests that plagioclase was in equilibrium with the host melt at the time of crystallisation.

Given that lavas from Rapuhia Seamount and Giljanes Seamount erupted through a crustal plateau, plagioclase compositions are more likely to have been modified through secondary processes such as plagioclase accumulation and/or magma mixing. Because plagioclase has a lower density than that of tholeiitic magma $\left(<2.75 \mathrm{~g} / \mathrm{m}^{3}\right.$ compared with $\sim 2.9 \mathrm{~g} / \mathrm{cm}^{3}$ : Timm et al. (2011)), earlier crystallising highCa plagioclase can float and be incorporated into subsequent ascending magma (e.g. Monowai: Timm et al. (2011)). However, the lack of $\mathrm{Eu} / \mathrm{Eu}^{*}$ anomalies in whole rock analyses argues against significant plagioclase accumulation (Section 4.2).

Many of the plagioclase phenocrysts in each sample contain diverse textures (Section 4.1), which indicates they could be subjected to variable magmatic conditions prior to eruption of the host magma. For example, plagioclase in Rapuhia Seamount and Giljanes Seamount include phenocrysts that display classical disequlibrium textures such as sieve-textured cores, oscillatory zoning, and both normal and reverse zoning (Sections 4.2). Mixing of magma of different melt compositions can result in highly variable compositions within a single phenocryst, where An contents between the core and rim may differ by up to 50 mol. \% (Bowen, 1913; Housh and Luhr, 1991). However, variations between the cores and rims in most zoned phenocrysts are usually within 5 - 10 mol. \% An, with maximum variations of up to 20 mol. \% An (Section 4.3). The fact that An and Or contents of all Rapuhia Seamount and Giljanes Seamount phenocrysts define single trends argues against mixing of magmas from different melt compositions. 


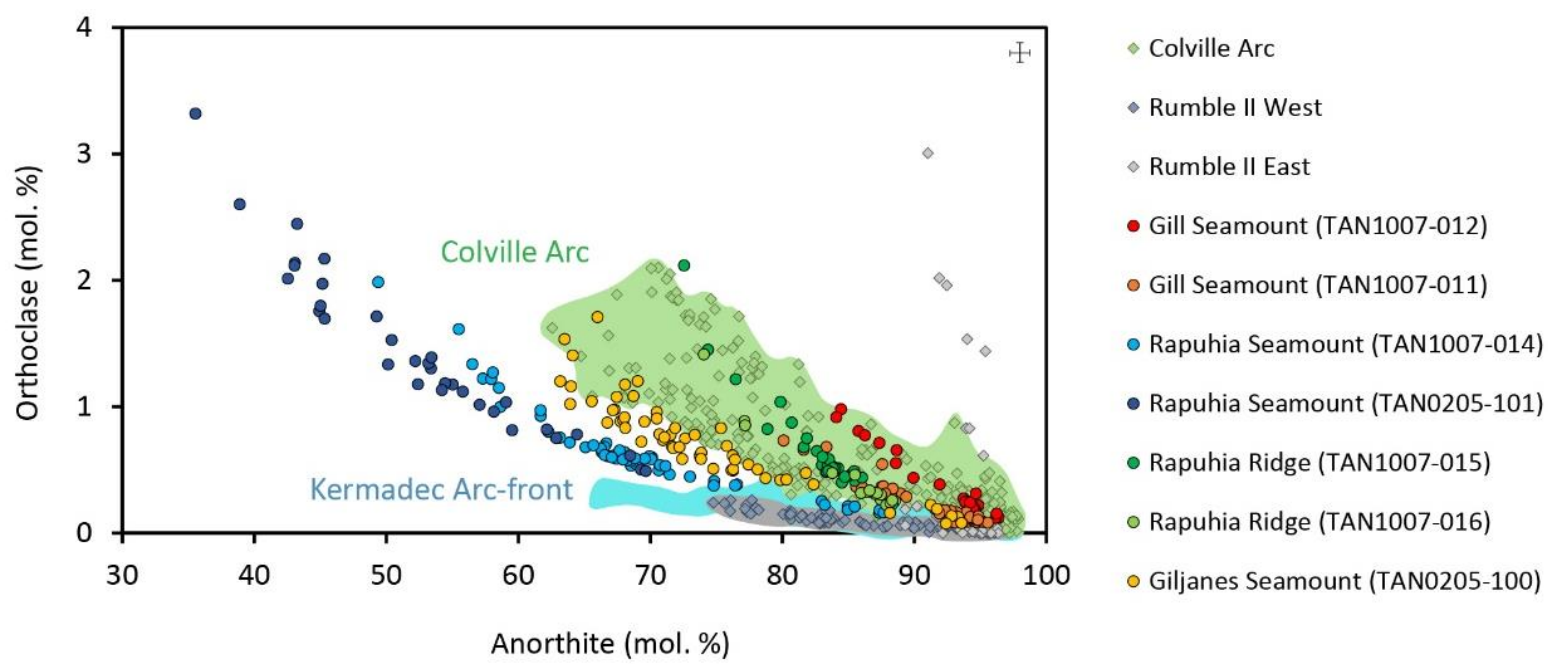

Figure 5.4. Plot of Orthoclase (Or) versus Anorthite (An) content for plagioclase crystals from the Colville Arc, Rumble II West, Rumble II East, Kermadec Arc-front, Gill Seamount, Rapuhia Seamount, Rapuhia Ridge, and Giljanes Seamount.

Compositions of plagioclase crystals from the Colville Arc, Rumble II West, and Rumble II East are the same as in (Figure 2.2). The green, grey and blue fields show the ranges of plagioclase compositions from the Colville Arc, Rumble II East, and Kermadec Arc-front, respectively. Colville Arc and Kermadec Arc-front plagioclase data are unpublished data from Wysoczanski pers. comms. (2016). Rumble II West and East plagioclase data come from Timm et al. (2016). The error bars denote 2 SD uncertainty estimates based on repeated analyses of the plagioclase standard NMNH 115900.

Figure 5.4 shows the compositions of plagioclase crystals from each back-arc volcano lava analysed by EPMA. They are characterised by distinct trends with different contents of Or for a given value of An. The occurrence of Or-rich plagioclase crystals in the Kermadec Arc has only been observed in Rumble II West (e.g. Timm et al., 2016) and in the Colville Arc (Wysoczanski, pers. comms., 2011). Their origin has not been constrained. Timm et al. (2016) suggested that they could have been derived from crystal accumulation from an earlier partial melt characterised by high $\mathrm{K}_{2} \mathrm{O}$ contents, or could have formed from an earlier melting event. Given that the samples all plot on single trends, accumulation of plagioclase is unlikely. Differences in Or contents are likely to be attributed to plagioclase crystallising from partial melts with different $\mathrm{K}_{2} \mathrm{O}$ contents. 


\subsubsection{Mafic Magma Differentiation}

For the purposes of this thesis, mafic magmas are defined as magmas containing $\leq 52 \mathrm{wt} \% \mathrm{SiO}_{2}$. As mentioned previously, compositions of olivine and clinopyroxene phenocrysts indicate that lavas evolved primarily by fractional crystallisation. Olivine, clinopyroxene and plagioclase are the main phenocryst mineral phases observed in lavas erupted from Gill Seamount and Rapuhia Ridge. The common occurrence of olivine, clinopyroxene, and plagioclase phenocrysts, suggests that major element compositions have primarily been modified by crystal fractionation of these mineral phases in lavas from Gill Seamount and Rapuhia Ridge.

Samples from both locations are characterised by trends of decreasing wt \% $\mathrm{MgO}$ and increasing $\mathrm{SiO}_{2}, \mathrm{Al}_{2} \mathrm{O}_{3}$, and $\mathrm{TiO}_{2}$. (Figure 4.18, 4.23). $\mathrm{MgO}$ contents also increase with increasing enrichment of compatible trace elements such as $\mathrm{Ni}$ and $\mathrm{Cr}$ (Figure 4.23).

Major and trace element patterns of the majority of Gill and Rapuhia Ridge lavas are consistent with fractional crystallisation of olivine + clinopyroxene \pm plagioclase. Decreasing $\mathrm{MgO}$ and $\mathrm{Ni}$ contents requires fractionation of olivine during magma differentiation. $\mathrm{Cr}$ decreases with decreasing $\mathrm{MgO}$, which indicates that clinopyroxene was a major fractionating phase. Basaltic lavas do not show any decrease in $\mathrm{Al}_{2} \mathrm{O}_{3}$ and $\mathrm{Sr}$ content with decreasing $\mathrm{MgO}$, indicating that plagioclase was not a major crystallising phase during differentiation of the mafic lava suites (Figure 4.18, 4.23).

\subsubsection{Silicic Magma Genesis}

The petrogenesis of silicic magmatism in oceanic settings has remained a point of contention. Like other intra-oceanic arcs (e.g. Izu-Bonin arc, South-Sandwich arc), the compositions of lavas in the Kermadec Arc are dominated by mafic and felsic endmember components (e.g. Wright et al., 2006), and have a distinctive lack of lavas with an intermediate composition. A number of studies have investigated silicic magma generation in the Kermadec Arc. Smith et al., (2003, 2006, 2010) proposed that silicic magmatism can be generated through partial melting from a lower crustal amphibolite. Haase et al., (2006) and Saunders et al., (2010) demonstrated that major 
and trace element tends in silicic lavas can be explained by fractional crystallisation from a basaltic parent. Recent work undertaken on glass, mineral and whole rock geochemistry (e.g. Barker et al., 2010; 2013; Timm et al., 2011) has suggested that observed trends in silicic magma compositions are primarily driven by open-system fractional crystallisation. Likewise, mineral and whole rock compositions of Rapuhia samples are best explained by assimilation - fractional crystallisation (AFC) processes.

Plagioclase and amphibole are the main phenocryst phases in silicic samples, with accessory ilmenite, magnetite and apatite. Trends of decreasing $\mathrm{Sr} / \mathrm{Y}$ and $\mathrm{Sr} / \mathrm{Zr}$ with increasing $\mathrm{SiO}_{2}$ can be explained by crystal fractionation of these mineral phases. Fractionation of plagioclase is supported by slightly decreasing Eu anomaly ${ }^{6}\left(\mathrm{Eu} / \mathrm{Eu}^{*}\right.$ = ca. 1.05-0.90), and increasing concentrations of HFSE, with increasing $\mathrm{SiO}_{2}$ content. Decreasing $\mathrm{P}_{2} \mathrm{O}_{5}$ with increasing $\mathrm{SiO}_{2}$ is indicative of apatite crystallisation (Figure 4.23). When compared with basaltic lavas from Gill Seamount and Rapuhia Ridge, dacitic lavas display geochemical trends in HFSE, $\mathrm{Sr} / \mathrm{Y}$ and $\mathrm{Sr} / \mathrm{Zr}$ with increasing $\mathrm{SiO}_{2}$ that follow typical fractional crystallisation trends, which is consistent with fractionation from a parental basaltic magma. However, no basaltic magma has been sampled from Rapuhia Seamount in this study.

Brophy (2008) demonstrated that magma of a dacitic composition can be generated through crustal anatexis from a crustal amphibolite or an amphibole-bearing intrusion. If dacitic magma generation involved crustal anatexis through partial melting of crustal amphibolite, then compositions of erupted lavas would be expected to be characterised by negative correlations between REE and $\mathrm{SiO}_{2}$, since REE have elevated amphibolite/melt partition coefficients with increasing wt $\% \mathrm{SiO}_{2}$ (e.g. Brophy, 2008).

Evidence for fractional crystallisation is supported by in situ analyses of plagioclase phenocrysts from Rapuhia Seamount, which are characterised by normal zoning (Section 4.1). Compositional zoning in plagioclase phenocrysts can be categorised into two main end-member types; zoning that reflects changes in local conditions such as pressure, temperature, and $\mathrm{H}_{2} \mathrm{O}$ content, and zoning that reflects large changes in composition as a result of changes in the composition of the residual

${ }^{6} \mathrm{Eu} / \mathrm{Eu}^{*}=\mathrm{Eu}_{\mathrm{N}} /\left(\mathrm{Sm}_{\mathrm{N}} * \mathrm{Gd}_{\mathrm{N}}\right)^{1 / 2}$, where all elements are normalised to the chondrite values of McDonough and Sun (1995). 
melt. Since the An content only varies between 5 - 10 mol. \% for a given plagioclase phenocryst, variations in the composition of individual crystals are likely to be attributed to changes in the small-scale conditions, such as temperature and pressure, and composition of the evolving melt. Phenocrysts and groundmass crystals also plot on single linear trends of Or content versus An content, which indicates that they were in equilibrium with the host melt when they crystallised.

As mentioned previously, Rapuhia Seamount, Yokosuka Seamount and Giljanes Seamount are situated on an elevated plateau. Owing to its lower density contrast, a thickened crustal layer is associated with slower magma ascent rates, and provides a reservoir for magmas to stall and undergo differentiation via assimilation \pm fractional crystallisation (DePaolo, 1981). The release of latent heat during crystallisation may promote assimilation of country wall rock, so it is highly likely that any magma passing through thickened crust will be modified by varying degrees of interaction with country wall rock. However, constraining the effect of assimilation on magma genesis in the dacitic suite requires determining the isotopic signatures (e.g. ${ }^{87} \mathrm{Sr} /{ }^{86} \mathrm{Sr}$ ) of both the country rock and the differentiated magma, as magma assimilation will result in elevated ${ }^{87} \mathrm{Sr} /{ }^{86} \mathrm{Sr}$ ratios when compared with undifferentiated basaltic magmas. A detailed examination into the petrogenesis of silicic magmatism in the Havre Trough back-arc stratovolcanoes is beyond the scope of this study.

\subsection{Mantle Processes and Source Implications}

The relative contributions from subduction-derived aqueous fluids and sediment melts into the back-arc mantle wedge remains unclear in regard to back-arc volcano magma genesis. Aqueous fluids are widely regarded to be released at pressures $<4 \mathrm{GPa}$ and temperatures of between $600-700{ }^{\circ} \mathrm{C}$ (Kessel et al., 2005). A sediment component could modify the composition of back-arc volcano melts via bulk mixing, the release of supercritical fluids (e.g. Izu Arc: Tollstrup et al. (2010)), or through the transfer of sediment-derived melts (e.g. Kasuga chain, Mariana arc: Tollstrup and Gill (2005)). Variations in the subduction component along strike for Kermadec Arc-front magmas have been attributed to the interplay of increasing 
sediment thickness on the subducting plate (i.e.. $200 \mathrm{~m}$ at $30^{\circ} \mathrm{S}$ to $500 \mathrm{~m}$ at $36^{\circ} \mathrm{S}$ ), and southward decreasing rates of subduction (i.e. $<7 \mathrm{~cm} / \mathrm{yr}$ in the southern Kermadec Arc, compared with $24 \mathrm{~cm} / \mathrm{yr}$ at the Tonga Arc), with only southern Kermadec Arc magmas requiring a sediment melt component in their source (DeMets et al., 1994; Haase et al., 2002; Smith and Price, 2006). The Rumble V Ridge, located in the southern KAHT at $36^{\circ} \mathrm{S}$, is an archetypal example of back-arc cross-arc volcanism, where magmas also require a sediment melt slab-derived component (Todd et al., 2010).

The back-arc volcanoes investigated in this study are located in the southern KAHT, to the north of the Rumble V Ridge, at $34.5^{\circ} \mathrm{S}$. Their similar array to the Rumble V Ridge led Wysoczanski et al. (2010) to originally suggest that they may also be an expression of a cross-arc chain. They are enriched in LILE and LREE with respect to N-MORB, which suggests that their sources are modified by significant slab-derived components extending to at least $80 \mathrm{~km}$ behind the arc-front. The occurrence of these stratovolcanoes in the southern Havre Trough raises several questions:

1. What is the extent of fluid and sediment melt transfer beneath back-arc volcanoes and how does it compare with processes that drive volcanism at the arc-front and the back-arc basins?

2. What is the composition of the ambient mantle wedge from which the back arc volcano melts are derived, and is there evidence for heterogeneity in the back-arc mantle?

3. Can the location of these back-arc stratovolcanoes and cross-arc chains be linked to source variations?

To minimise the effects of crustal contamination and fractional crystallisation, only basaltic lavas from Gill Seamount and Rapuhia Ridge have been used to examine the effect of source processes in the mantle wedge. Since Rapuhia Seamount, Yokosuka Seamount and Giljanes Seamount are located at near-similar distances from the arc-front, partial melting is predicted to occur at similar temperatures and distances above the slab surface for all three of these volcanoes. 


\subsubsection{The Southern Havre Trough Ambient Mantle Wedge}

The ambient mantle wedge is defined as the mantle wedge prior to being modified by subduction-derived components (Todd et al., 2010; Woodhead et al., 2012). Back-arc basin magmas in the southern Havre Trough are regarded as being derived from a source that has been variably modified from an original depleted MORB mantle source (Wysoczanski et al., 2006), through the addition of subduction slab-derived components and from partial melting events. Previous studies have regarded a single depleted basalt (sample PPTUW/5) to be representative of the composition of the ambient mantle wedge in the southern Havre Trough (Gamble et al., 1993a, 1996). Subsequently, six samples from the Havre Trough were suggested by Todd et al. (2010) to be representative of the unmodified mantle, on the basis of having minimal subduction contributions from subduction components (i.e. $\mathrm{Hf} / \mathrm{Hf}^{*}$ $\geq 1.0, \mathrm{~Pb} / \mathrm{Ce} \leq 0.1$ ), and having similar trace element patterns to the depleted MORB mantle of Workman and Hart (2005).

Samples analysed here from the western Havre Trough back-arc basins are all characterised by negative $\mathrm{Hf} / \mathrm{Hf}^{*}$ anomalies, and ratios of $\mathrm{Pb} / \mathrm{Ce}$ generally $>1.0$, and are therefore inferred to be modified by subduction components. For the purposes of this study, the ambient Havre Trough mantle wedge composition of Todd et al. (2010) will be assumed to represent the primary mantle wedge composition prior to modification.

Ratios of $\mathrm{Nb} / \mathrm{Yb}$ in some samples are similar to ratios from previous arc-front analyses, however they are noticeably higher in lavas from Gill Seamount and Rapuhia Ridge (i.e. 2.3 - 2.9 in Gill Seamount, 1.2 - 2.1 in Rapuhia Ridge), (Figure 5.5), resulting from higher $\mathrm{Nb}$ concentrations, with similar $\mathrm{Yb}$ contents. Given that all the samples from each lava suite have similar but distinct $\mathrm{Nb} / \mathrm{Yb}$ ratios (Figure 5.5), it is unlikely that their high $\mathrm{Nb}$ comes from contamination during sample preparation and analysis. Therefore, differences in $\mathrm{Nb} / \mathrm{Yb}$ ratios between arc-front and back-arc volcanics are likely to reflect differences in mantle source processes.

Release of $\mathrm{Nb}$ by melting of rutile during subduction has been suggested to account for increased $\mathrm{Nb}$ concentrations in some back-arc magmas (e.g. Pearce et al., 2005). However, slab surface temperatures underneath the western Havre Trough have 
been modelled to be between $~ 870-940{ }^{\circ} \mathrm{C}$ (Syracuse et al., 2010). Under those conditions, $\mathrm{Nb}$ is expected to be retained in rutile (Hermann and Rubatto, 2009; Skora and Blundy, 2010), and therefore unlikely to be mobilised in any sediment melt. Alternatively, small-degree partial melting of mantle peridotite can also result in elevated $\mathrm{Nb} / \mathrm{Yb}$ ratios $\left(\mathrm{D}_{\mathrm{Nb}}>\mathrm{D}_{\mathrm{Yb}}\right.$ for most peridotite-bearing minerals apart from spinel: Kelemen et al. (1993)). However, the resulting ratios of $\mathrm{Nb} / \mathrm{Yb}$ would still be lower than those observed in Gill Seamount and Rapuhia Ridge lavas. Arc-style magmatism is also predicted to be associated with greater degrees of partial melting than back-arc rift magmatism (e.g. Kelley et al., 2006), yet $\mathrm{Nb} / \mathrm{Yb}$ are higher than in the back-arc basin samples (Figure 5.5). Instead, the elevated ratios of $\mathrm{Nb} / \mathrm{Yb}$ observed in lavas from Gill Seamount and Rapuhia Ridge are best explained by partial melting of a relatively undepleted mantle source.

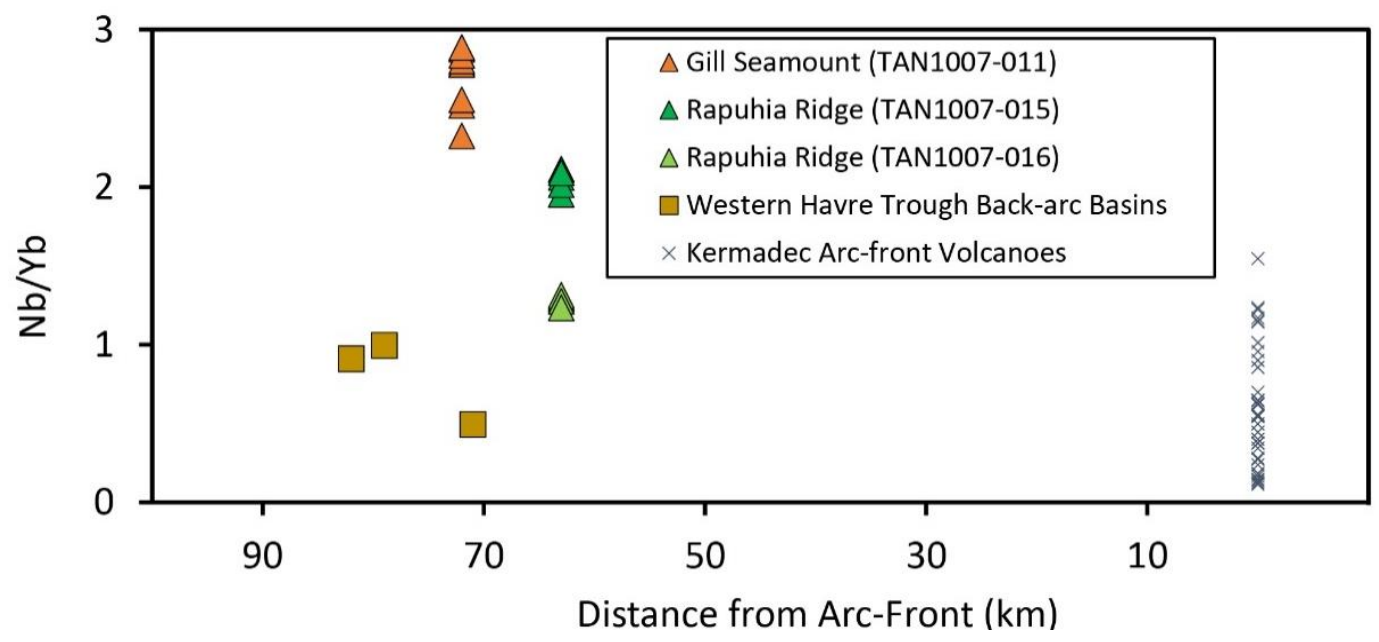

Figure 5.5. Plot showing the relationship between a) $\mathrm{Nb} / \mathrm{Yb}$ and distance from the Kermadec arc-front.

Data for Kermadec Arc-front Volcanoes come from Ewart et al. (1977); Gamble et al. (1990, 1993a, 1993b, 1994, 1996); Haase et al. (2002); Wysoczanski et al. (2006; 2012).

The extent of source depletion in back-arc settings has been evaluated using $\mathrm{Nb} / \mathrm{Yb}$ (Pearce and Stern, 2006). When compared with arc-front analyses, $\mathrm{Nb} / \mathrm{Yb}$ is higher in the back-arc volcano lavas, and positively correlates with increasing distance from the arc-front (Figure 5.5). These patterns have been observed in multiple arcback-arc settings (e.g. Mariana arc: Pearce et al. (2005); Iz-Bonin Arc: Hochstaedter et al. $(2000,2001))$, and can be explained by progressive melt extraction during 
trenchward advection of the mantle wedge (e.g. Hochstaedter et al., 2000). Trenchward convection has also previously been suggested to account for the pattern of $\mathrm{Nb} / \mathrm{Yb}$ observed in western Rumble V Ridge lavas (e.g. Todd et al., 2010). As with Gill Seamount and Rapuhia Ridge, Nb/Yb ratios observed in western Rumble V Ridge lavas are generally higher than those observed in arc-front samples (Todd et al., 2010), (Figures 5.5, 5.6). Notably $\mathrm{Nb} / \mathrm{Yb}$ ratios differ for lavas from Gill Seamount and Rapuhia Ridge (Figures 5.5, 5.6). This suggests that there may be a linear progression in the degree of melt extraction associated with the mantle source for Gill Seamount and Rapuhia Ridge. The extent of melt extraction is more linear than previously suggested by Todd et al. (2010) for the Rumble V Ridge. However, additional sampling and analysis of back-arc lavas are required to confirm this.

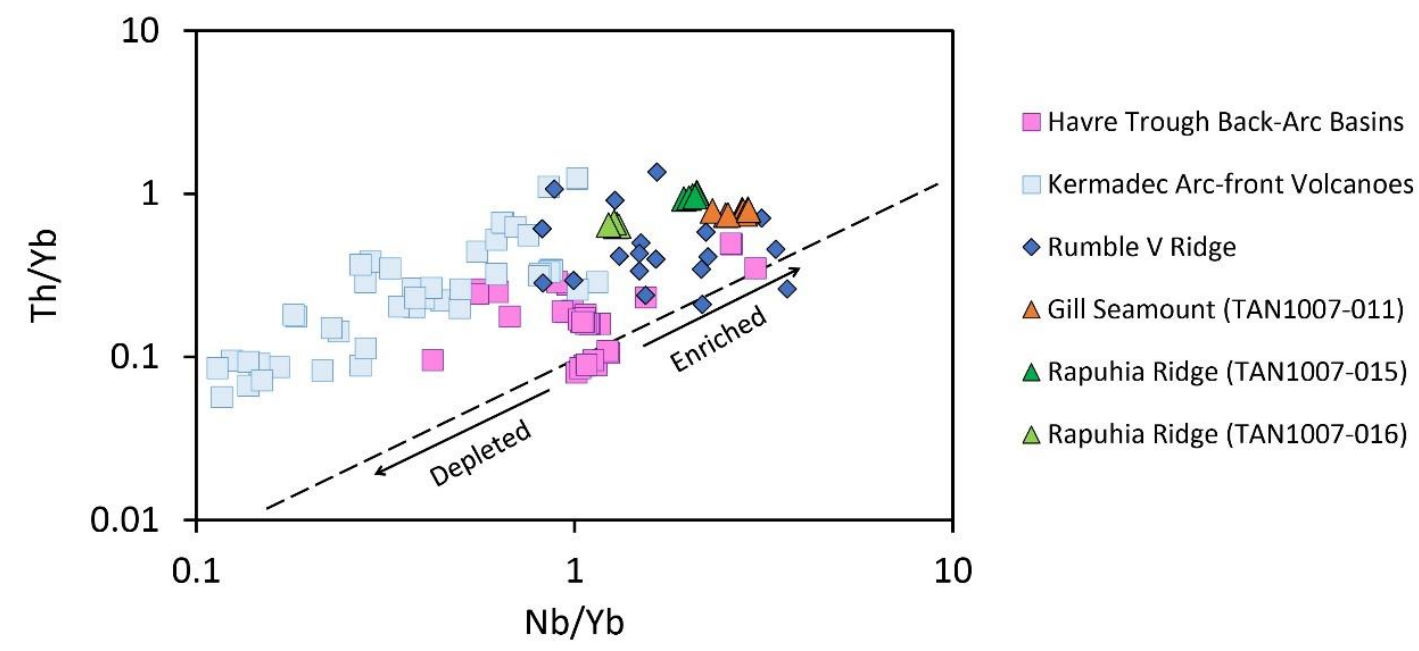

Figure 5.6. Plot of $\mathrm{Th} / \mathrm{Yb}$ versus $\mathrm{Nb} / \mathrm{Yb}$.

Data for Rumble V samples as the same as those in Figure 5.5, and come from Todd et al., (2010). Data for Kermadec Arc-front Volcanoes are the same as in Figure 5.5, and come from Gamble et al., (1990); Haase et al., (2002) Wysoczanski et al., (2006; 2012); Todd et al., (2011). Dashed line represents the MORB mantle array from Pearce (2008), where the mantle is regarded as being enriched when $\mathrm{Nb} / \mathrm{Yb}>1$, and depleted when $\mathrm{Nb} / \mathrm{Yb}<1$.

The presence of elevated $\mathrm{Nb} / \mathrm{Yb}$ ratios in back-arc lavas is significant with regard to interpreting the nature of the mantle source. Elevated ratios of $\mathrm{Nb} / \mathrm{Yb}$ can be explained by partial melting of an incoming mantle that is less depleted than that of $\mathrm{N}-\mathrm{MORB}$. If the pattern of mantle flow in the Havre Trough is a consequence of trenchward advection, then the ensuing mantle sourcing arc-front volcanoes would have undergone more melt extraction. Arc-front magmas would therefore originate from a more depleted mantle source (i.e. lower $\mathrm{Nb} / \mathrm{Yb}$ ratios). 
A less depleted mantle source underneath the back-arc volcanoes and ridges may also reflect the presence of fertile regions in the Havre Trough mantle that are preferentially melted. Ratios of $\mathrm{Nb} / \mathrm{Yb}$ observed in western Havre Trough BABB are lower than those of the back-arc volcano lavas. (Figures 5.5, 5.6). This suggests that differences in $\mathrm{Nb} / \mathrm{Yb}$ could reflect differences in the mantle source composition between back-arc volcanoes and back-arc basins. Back-arc volcano magmas may have originated from a high- $\mathrm{Nb}$, fertile source, which has then undergone higher degrees of partial melting. Both Gill Seamount and Rapuhia Ridge, and the western Rumble V Ridge basalts appear to originate from a more fertile (higher $\mathrm{Nb} / \mathrm{Yb}$ ) source than the western Havre Trough Back-Arc basin basalts, albeit based on limited sampling. Lateral heterogeneity in the fertility of the incoming mantle may contribute to the location of the trench orthogonal constructional edifices in the back-arc region, where more readily fusible mantle facilitates formation of stratovolcanoes and/or ridges. Further analyses of back-arc basins, particularly from within the deep basins, are needed to determine if this is a consistent difference between regions of constructional volcanism and deep basins in the Havre Trough.

\subsubsection{Contributions from Slab-Derived Components}

The extent to which arc magmas are modified by subduction can be examined by comparing ratios of elements that preferentially partition into different slab-derived components. Examples of commonly used ratios include $\mathrm{Ba} / \mathrm{Nb}$ for assessing the extent of total subduction component, $\mathrm{Ba} / \mathrm{Th}$ as a proxy for aqueous fluid enrichment, and $(\mathrm{La} / \mathrm{Sm})_{\mathrm{N}}$ representing deeper subduction components associated with sediment melts and/or supercritical fluids (Elliot et al., 1997; Kent and Elliot, 2002; Pearce and Stern, 2006; Wysoczanski et al., 2006)). Samples from Gill Seamount and Rapuhia Ridge are characterised by ratios of $\mathrm{Ba} / \mathrm{Nb}$ and $\mathrm{Ba} / \mathrm{Th}$ that are more comparable to Havre Trough BABB than Kermadec arc-front lavas (Figure 5.7). Ratios of $\mathrm{Ba} / \mathrm{Nb}$ are $<50$ for Gill Seamount lavas, and <120 for Rapuhia Ridge lavas. By comparison, most arc-front lavas have $\mathrm{Ba} / \mathrm{Nb}$ ratios that are greater than 200 , with some reaching up to 500 (Figure 5.7). Ratios of $(\mathrm{La} / \mathrm{Sm})_{\mathrm{N}}$ range from 3.1 - 3.4 for Gill Seamount, and ca. 2.8 - 3.5 for Rapuhia Ridge (Figure 5.7). These ratios are comparable to the highest sediment melt ratios determined from any southern KAHT lavas (Figure 5.7). 

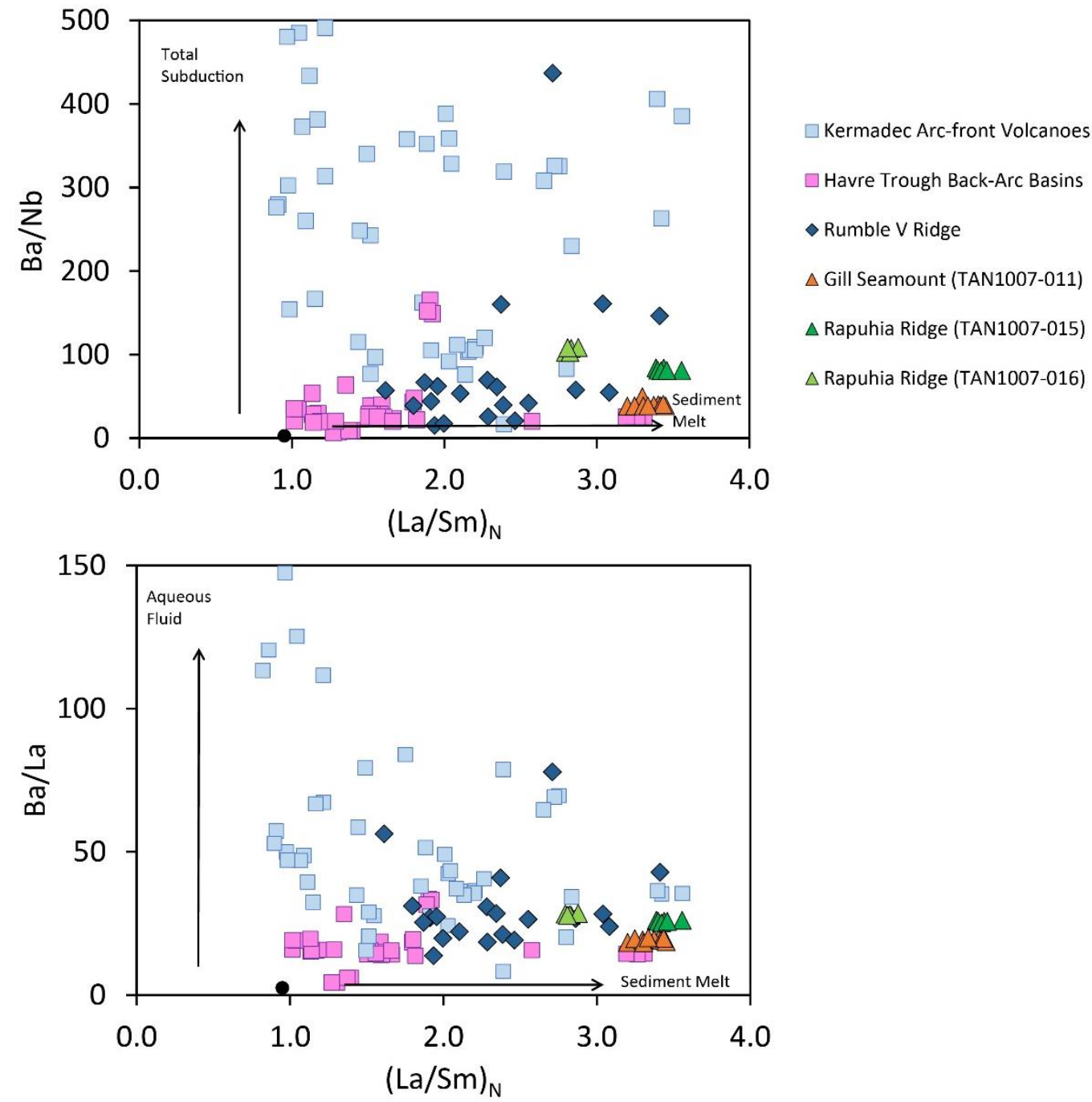

Figure 5.7. Plots of a) $\mathrm{Ba} / \mathrm{Nb}$, and b) $\mathrm{Ba} / \mathrm{Th}$ versus $(\mathrm{La} / \mathrm{Sm})_{\mathrm{N}}$, for lavas from Gill Seamount, Rapuhia Ridge, the Rumble V Ridge, Kermadec Arc-front volcanoes., and Havre-Trough Back-arc basins.

These plots show the extent at which aqueous fluid and sediment melt slab-derived subduction components (represented by black arrows) modify the composition of lavas from Gill Seamount and Rapuhia Ridge, in comparison to the Rumble V Ridge, Kermadec Arc-front volcanoes, and Havre Trough Back-arc basins. (The ${ }_{\mathrm{N}}$ denotes normalised to N-MORB). Black circle represents $\mathrm{Ba} / \mathrm{Nb}, \mathrm{Ba} / \mathrm{La}$, and $\mathrm{La} / \mathrm{Sm}$ values for N-MORB. Normalising N-MORB values are from Sun and McDonough (1989). Analyses for KAHT and Rumble V Ridge lavas are the same as in Figure 2.3, and come from Gamble et al., (1993a, 1994); Haase et al., (2002); Wysoczanski et al., (2006); Todd et al., (2010, 2011); Timm et al., (2016).

\subsubsection{The Role of Fluid Transfer from the Subducting Slab}

The mantle source for Kermadec arc-front magmas is widely regarded to be modified by the release of aqueous fluids and sediment melts (e.g. Hasse et al., 2002; Wysoczanski et al., 2006). Experimental studies using basaltic eclogites have demonstrated that aqueous fluids are transferred into the mantle wedge at relatively 
low temperatures $\left(700-800{ }^{\circ} \mathrm{C}, 4 \mathrm{GPa}\right)$, and shallow depths $(\leq 180 \mathrm{~km})($ Kessel et al., 2005). In the western Havre Trough, the subducting slab beneath Gill Seamount has been modelled to be $\geq 280 \mathrm{~km}$ deep (Syracuse et al., 2010, Todd et al., 2010), which exceeds the critical threshold for which aqueous fluids are stable and in equilibrium with subducting eclogite-bearing mineral phases (Hermann et al., 2006). The fluidtransfer tracer of $\mathrm{Ba} / \mathrm{Nb}$ and $\mathrm{Ba} / \mathrm{Th}$ associated with Gill Seamount and Rapuhia Ridge lavas are also significantly lower than those of arc-front magmas, indicating that their sources were modified by the addition of shallow-level aqueous fluids (Figure 5.7). Therefore, contributions from an aqueous fluid component is unlikely, and any fluidaddition into the distal back-arc underneath these regions is likely to be via a supercritical fluid.

Supercritical fluids are commonly referred to as solutions that are released from the subducting plate into the mantle wedge at conditions $>4 \mathrm{GPa}$, which exceed the sub-critical threshold for aqueous fluids (Kessel et al., 2005; Hermann et al., 2006). Mineral solubility data indicates that supercritical fluids have compositions that resemble those of aqueous fluids at low temperatures, but are more similar to hydrous melts as temperatures increase (Hermann et al., 2006). Element mobility in both supercritical fluids and melts remains an unclear topic in subduction zone magma genesis, and is widely regarded to be affected by factors including changes in pressure and temperature conditions, as well as the composition of mineral phases in the subducting slab (Hermann et al., 2006). For the purposes of this study, any fluid-phase that transfers elements at pressures $>4 \mathrm{GPa}$ is referred to as a supercritical fluid.

Todd et al. $(2010,2011)$ inferred that, in basalts from the Rumble V cross-arc ridge and southern Havre Trough back-arc rift basalts, elevated LILE concentrations could be explained by fluid enrichment via a supercritical fluid. They noted that $\mathrm{Ba} / \mathrm{Nb}$ and $\mathrm{Ba} / \mathrm{Th}$ ratios of Rumble $\mathrm{V}$ cross-chain and Havre Trough back-arc lavas showed minimal overlap with those of most Kermadec-arc front analyses (Figure 5.7). They concluded that mantle sources associated with the Rumble V Ridge and Havre Trough $\mathrm{BABB}$ required a negligible contribution from an aqueous fluid slab-derived component (Todd et al., 2010).

Western Havre Trough BABB are characterised by similar ratios of $\mathrm{Ba} / \mathrm{Nb}$ and $\mathrm{Ba} / \mathrm{Th}$ compared to analyses of Gill Seamount and Rapuhia Ridge (Figure 5.7). Given 
that supercritical fluids have been inferred to modify the Havre Trough mantle wedge, it is possible that back-arc stratovolcanoes and western Havre Trough are modified by a similar supercritical fluid subduction component. However, the back-arc basin samples analysed in this study have highly variable LILE concentrations (Section 4.2), and have been affected by alteration. Constraining the extent of fluid and melt transfer into the western Havre Trough will require further sampling and analysis.

\subsubsection{The Role of Sediment Transfer from the Subducting Slab}

Contrasting trace element and isotopic signatures between Rumble V crosschain lavas and southern Havre Trough back-arc rifts were attributed by Todd et al., $(2010,2011)$ to fundamental differences associated with the subducting slab-derived components. They found that trace element profiles of back-arc rift samples could be explained by a supercritical fluid as the predominant slab-derived component, and that analyses of Rumble V Ridge lavas involved a sediment-melt as the prevailing subduction-derived component. Most Rumble V Ridge analyses are characterised by high ratios of $(\mathrm{La} / \mathrm{Sm})_{\mathrm{N}}\left(\right.$ Figure 5.5). Similarly high $(\mathrm{La} / \mathrm{Sm})_{\mathrm{N}}$ ratios are observed in a few southern Kermadec arc- front samples, where their sources are known to be modified by subducting sediment (Gamble et al., 1996; Haase et al., 2002), (Figure 5.7). Lavas from Gill Seamount and Rapuhia Ridge are also characterised by high $(\mathrm{La} / \mathrm{Sm})_{\mathrm{N}}$ ratios (Figure 5.7), which suggests that the main subduction component modifying their source requires the transfer of sediment from the subducting slab.

Lavas from Gill Seamount generally contain higher ratios of $(\mathrm{La} / \mathrm{Sm})_{\mathrm{N}}$ than most analyses from Rapuhia Ridge (Figure 5.7). Although sediment melt ratios are higher for some of the TAN1007-015 analyses, their increased La concentrations could be attributed to fractional crystallisation (see Section 5.2). Samples from Gill Seamount are also characterised by steeper REE patterns than those from TAN1007016 Rapuhia Ridge samples. This could indicate that the sediment component is higher in samples from Gill Seamount than Rapuhia Ridge. An increase in mass fraction of sediment release has also been inferred for Rumble V Ridge basalts (Todd et al., 2010), and in the Izu-Bonin arc (Tollstrup et al., 2010). 
As mentioned previously, sediment-derived components can be transferred from the subducting slab into the mantle wedge through an aqueous fluid, bulk mixing, or from the release of sediment-derived melts. Ratios of $\mathrm{Ba} / \mathrm{Nb}$ and $\mathrm{Ba} / \mathrm{Th}$ for Gill Seamount and Rapuhia Ridge lavas are too low for their compositions to be explained by the addition sediment via an aqueous fluid, (Figure 5.7). The subducting slab is also inferred to be at pressures greater than the critical threshold for aqueous fluids (Syracuse et al., 2010).

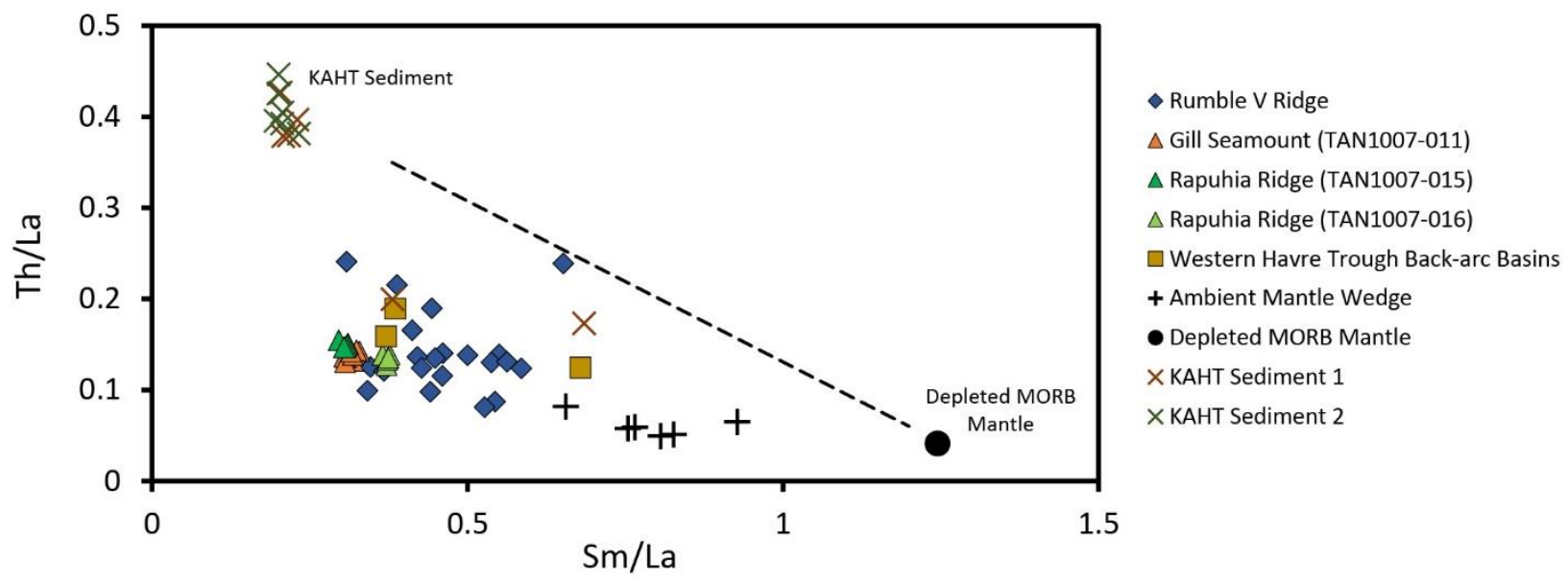

Figure 5.8. Plot of Th/La vs Sm/La, showing the effect of sediment mixing between bulk KAHT sediment and depleted MORB mantle.

Modified from Todd et al. (2010). Mixing line is from Plank, (2005). Values for bulk sediment are from Gamble et al. (1996); Woodhead et al. (2001), and come from $32.5-41^{\circ} \mathrm{S}$. Ambient mantle wedge compositions are from Gamble et al. (1994); Haase et al. (2002); Wysoczanski et al. (2006). Depleted N-MORB mantle composition is from Workman and Hart, (2005). Rumble V Ridge compositions are from Todd et al. (2010).

If sediment was transferred into the mantle wedge through bulk mixing with depleted mantle, then the resulting arc magma compositions would plot on a straight mixing line (Plank, 2005). (Figure 5.5) shows the predicted compositions of mixtures of bulk sediment and depleted MORB mantle. All back-arc volcano lavas are characterised by ratios of $\mathrm{Th} / \mathrm{La}$ that are at least an order of magnitude lower those predicted by bulk mixing at a given value of $\mathrm{Sm} / \mathrm{La}$, which argues against bulk mixing between sediment and depleted N-MORB mantle (Figure 5.8). Since the Th/La ratio in back-arc magmas is regarded to be derived from locally subducting sediment (e.g. Plank, 2005), lower ratios of Th/La observed in Gill Seamount and Rapuhia Ridge 
lavas implies that sediment addition into the mantle was associated with fractionation of Th from La.

\subsubsection{Sediment Melt Transfer into the Mantle Wedge}

Fractionation of Th from REE in back-arc magmas has previously been explained by the transfer of sediment-derived partial melts from the subducting slab into the mantle wedge (e.g. Tollstrup and Gill, 2005; Duggen et al., 2007). Partial melting of subducting sediment requires temperature conditions to exceed $650^{\circ} \mathrm{C}$ (Nichols et al., 1994; Peacock and Wang, 1999), and for relatively slow rates of subduction in order for sediment melts to modify the mantle wedge associated with arc magmas (Haase et al., 2002). The thickness of subducting sediment at the southern Kermadec margin is estimated to be $~ 500$ m (Carter et al., 1996; Gamble et al., 1996; Turner et al., 1997). Haase et al. (2002) demonstrated that, owing to the interplay of increased sediment thickness on the subducting slab and relatively slow subduction rates ( $<7 \mathrm{~cm} /$ year), southern Kermadec arc magmas can be modified by the addition of partial sediment melts.

Todd et al. (2010) modelled the effect of sediment partial melting on the composition of Rumble V Ridge magmas using mineral/melt partition coefficients for HFSE and REE in residual mineral phases during sediment melting (Table 5.3). They used Hf/Hf* anomalies to reason that compositions of Rumble V Ridge lavas were modified by the addition of sediment melts, whereas residual phases in the subducting slab can cause fractionation of HFSE and Th from REE. Hf/Hf* anomalies have previously been used to constrain the effect of partial melting of subducting sediment on back-arc volcano magma compositions (e.g. Tollstrup and Gill, 2005). HFSE/REE fractionation requires the presence of residual accessory phases during partial sediment melting that are characterised by high solid/melt partitioning coefficients for HFSE (Rudnick et al., 2000; Tollstrup and Gill, 2005; Carpentier et al., 2009). In the southern Kermadec Arc, the accessory mineral phases that are present in subducting sediments include rutile, zircon and monazite (Carter et al., 1996; Gamble et al., 1996; Carpentier et al., 2009). These minerals are all characterised by high mineral/melt partitioning coefficients for HFSE with respect to REE (Table 5.3). 


\begin{tabular}{clll} 
Element & $(\mathbf{D})_{\text {Rutile }}$ & $(\mathbf{D})_{\text {Zircon }}$ & $(\mathbf{D})_{\text {Monazite }}$ \\
\hline $\mathbf{T h}$ & $0.54^{\mathrm{a}}$ & $41^{\mathrm{b}}$ & $3919.74^{\mathrm{c}}$ \\
$\mathbf{N b}$ & $540^{\mathrm{a}}$ & & \\
$\mathbf{L a}$ & $0.237^{\mathrm{a}}$ & & $2736.93^{\mathrm{c}}$ \\
$\mathbf{S r}$ & $0.048^{\mathrm{a}}$ & $8.5^{\mathrm{b}}$ & $3518.77^{\mathrm{c}}$ \\
$\mathbf{N d}$ & $0.684^{\mathrm{a}}$ & $16^{\mathrm{b}}$ & $5543.94^{\mathrm{c}}$ \\
$\mathbf{S m}$ & $2.4^{\mathrm{a}}$ & $2005^{\mathrm{b}}$ & \\
$\mathbf{Z r}$ & $3.79^{\mathrm{a}}$ & $3476^{\mathrm{b}}$ & \\
$\mathbf{H f}$ & $4.61^{\mathrm{a}}$ & $345^{\mathrm{b}}$ & \\
$\mathbf{Y b}$ & $0.0158^{\mathrm{a}}$ & &
\end{tabular}

Table 5.3. List of Mineral/melt partition coefficients for accessory mineral phases present in subducting sediment at the southern Kermadec Arc, modelled by Todd et al. (2010).

Values of (D) correspond to partition coefficients for elements during partial melting of S-type granites. Values are left blank where no partition coefficient data were used. Data obtained from a) Foley et al. (2000), b) Rubatto and Hermann (2007), and c) (Bea and Montero (1999).

Figure 5.9 shows the effects of partial melting of sediment on the composition of back-arc volcano melts, where accessory residual phases include zircon, monazite and rutile. All the samples from Gill Seamount and Rapuhia Ridge are characterised by negative $\mathrm{Hf} / \mathrm{Hf}^{*}$ anomalies between 0.6 and 0.8 (Figure 5.9), which can be explained by partial melting of subducting sediment with residual zircon. The observed trend in Figure 5.8, where back-arc volcano lavas are characterised by lower ratios of Th/La compared to those of bulk sediment, suggests that monazite is present as a residual phase during subduction. Although Gill Seamount and Rapuhia Ridge are characterised by elevated ratios of $\mathrm{Nb} / \mathrm{Yb}$ compared to arc-front analyses, (Figure 5.5), addition of sediment partial melt generated without rutile present as an accessory phase would result in significantly elevated ratios of $\mathrm{Nb} / \mathrm{Yb}$ relative to $\mathrm{Th} / \mathrm{Yb}$, since Th is more incompatible than $\mathrm{Nb}$ in rutile (Table 5.3). Ratios of $\mathrm{Nb} / \mathrm{Yb}$ range from 2.3 - 2.9 for Gill Seamount, and 1.2 - 2.2 for Rapuhia Ridge (Figures 5.5, 5.6), and ratios of $\mathrm{Th} / \mathrm{Yb}$ range from $0.7-0.8$ for Gill Seamount, and $0.6-1.0$ for both lava suites from Rapuhia Ridge. These differences in $\mathrm{Nb} / \mathrm{Yb}$ and $\mathrm{Th} / \mathrm{Yb}$ are too low to be explained by sediment melting in the absence of residual rutile. Therefore, rutile is also likely to be a residual phase during subduction.

A number of studies have proposed that Hf may become mobilised during subduction (e.g. Woodhead et al., 2001) and therefore reflects bulk sediment addition into the mantle wedge as opposed to a partial melt. Todd et al. (2010) argued that, on the basis of limited isotopic Hf variability observed between depleted MORB mantle and arc-front lavas, that Hf mobility is minimal in the Kermadec Arc. In the back-arc 
volcano analyses, the apparent fractionation of Th from REE cannot be explained by bulk mixing (Figure 5.8). Negative Hf/Hf* anomalies are therefore inferred to reflect fractionation of $\mathrm{Hf}$ from REE during sediment-derived partial melting in the presence of residual zircon.

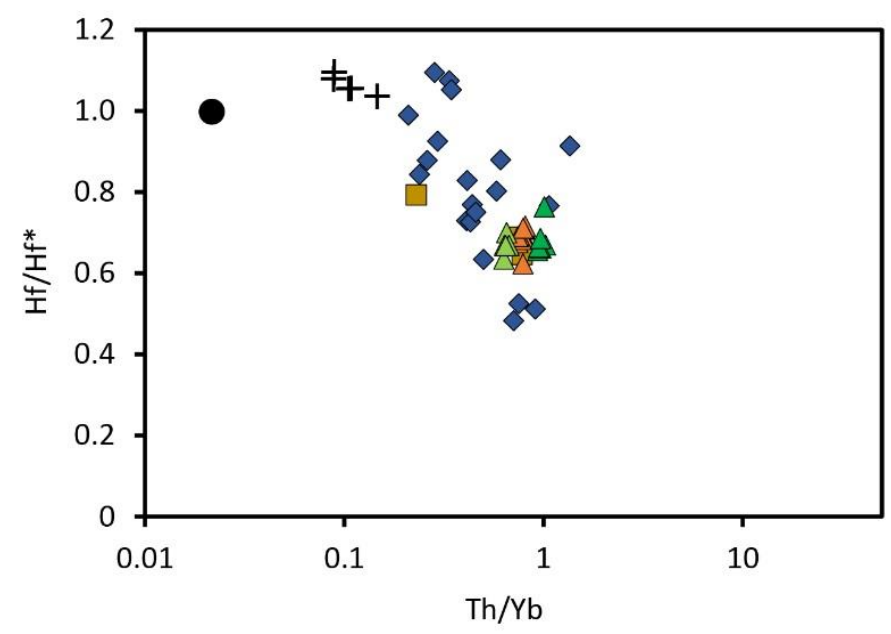

$\diamond$ Rumble V Ridge

$\square$ Western Havre Trough Back-arc Basins

$\triangle$ Gill Seamount (TAN1007-011)

$\Delta$ Rapuhia Ridge (TAN1007-015)

$\triangle$ Rapuhia Ridge (TAN1007-016)

+ Ambient Mantle Wedge

- Depleted MORB Mantle

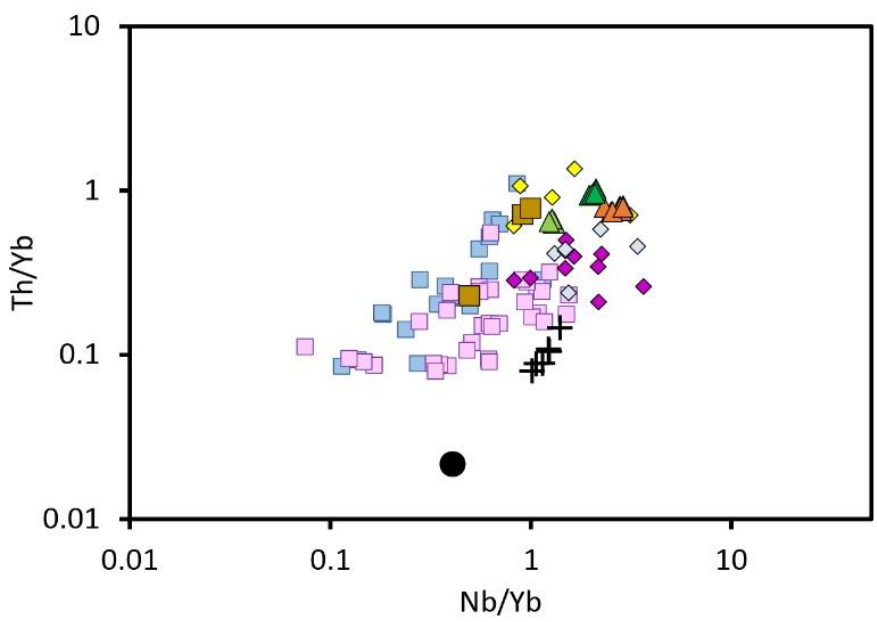

$\square$ Kermadec Arc-front Volcanoes

$\square$ Havre Trough Back-arc Basins

$\diamond$ Rumble V Ridge (Eastern Enriched)

$\diamond$ Rumble V Ridge (Eastern)

$\diamond$ Rumble V Ridge (Western)

$\triangle$ Gill Seamount (TAN1007-011)

$\Delta$ Rapuhia Ridge (TAN1007-015)

$\triangle$ Rapuhia Ridge (TAN1007-016)

$\square$ Western Havre Trough Back-arc Basins

+ Ambient Mantle Wedge

- Depleted MORB Mantle

Figure 5.9. Plots of a) $\mathrm{Hf} / \mathrm{Hf}^{*}$ versus $\mathrm{Th} / \mathrm{Yb}$ and b) $\mathrm{Th} / \mathrm{Yb}$ versus $\mathrm{Nb} / \mathrm{Yb}$.

Modified from Todd et al., (2010). Ambient mantle wedge compositions are from Gamble et al., (1994); Haase et al., (2002); Wysoczanski et al., (2006). Depleted N-MORB mantle composition is from Workman and Hart (2005). Analyses for KAHT and Rumble V Ridge lavas come from Gamble et al. (1993a, 1994); Haase et al. (2002); Wysoczanski et al. (2006), Todd et al. (2010, 2011); Timm et al. (2016). 
Todd et al. (2010) found that trace element patterns of Rumble V Ridge lavas can be explained by the addition of small-degree sediment-derived partial melts $(<0.5$ - $2.0 \%$ ) to the mantle wedge, characterised by lower ratios of $\mathrm{Th} / \mathrm{La}$ than bulk sediment (e.g. Figure 5.9). Their model included the residual accessory phases monazite, zircon and rutile present in minor abundances $(<0.5-2.0 \%)$. They showed that the mass fraction of sediment transfer into the mantle wedge increases with increasing distance from the arc-front. Higher $\mathrm{Hf} / \mathrm{Hf}^{*}$ anomalies in eastern Rumble $\mathrm{V}$ Ridge basalts compared with western Rumble V ridge analyses led them to suggest that the amount of residual zircon decreases with increasing distance from the subducting slab. They interpreted these differences between analyses of eastern and western Rumble V Ridge basalt analyses to increasing temperature with increasing depth to the subducting slab, as this would result in greater degrees of sediment partial melting, and less residual zircon.

Analyses of lavas from Gill Seamount and Rapuhia Ridge are characterised by distinct ratios of $\mathrm{Hf} / \mathrm{Hf} *$ and $\mathrm{Nb} / \mathrm{Yb}$ (Figures 5.5, 5.9). However, differences between their respective $\mathrm{Hf} / \mathrm{Hf} *$ and $\mathrm{Th} / \mathrm{Yb}$ are not as large as the ranges observed in Rumble V Ridge lavas (Figure 5.6). This could simply reflect the limited sampling of these back-arc volcano lavas, or their relative latitudinal proximity compared with the wider latitudinal range covered by the eastern and western Rumble V Ridge basalts (Figure 2.1). Given the observed variability between these back-arc stratovolcano ridges, sediment melting in the presence of residual phases has not been modelled in detail for this study. However, ratios of $\mathrm{Th} / \mathrm{Yb}$ and $\mathrm{Nb} / \mathrm{Yb}$ from of Gill Seamount and Rapuhia Ridge lavas are similar to those of Rumble V Ridge lavas, which indicates that their partial melts are influenced by similar subduction processes (Figures 5.5, $5.8,5.9)$. Their trace element patterns are therefore attributed to the addition of a sediment-derived partial melt, where residual monazite, zircon and rutile are present in minor abundances, similar in composition to the mantle source beneath the Rumble V Ridge. 


\subsection{Spatial Patterns}

Subduction processes associated with Gill Seamount and Rapuhia Ridge are comparable to processes inferred for back-arc volcanoes in other intra-oceanic arc settings. For example, Tollstrup and Gill (2005) attributed negative Hf/Hf* anomalies in lavas to contributions from sediment-derived partial melting with residual zircon originating from the subducting slab. Elliot et al. (1997) suggested that the slab derived component associated with Mariana Arc magmas involved a sediment melt component with rutile present as a residual phase. Although there are many examples of back-arc volcanoes that do not show evidence for a sediment melt component added from the subducting slab (e.g. Guguan cross-chain: Stern et al., 2006, Izu-Bonin Arc: Tollstrup et al., 2010), they have been interpreted as modified by a subducting slab component that decreases in total volume of material added, and changes in composition with increasing distance from the arc front.

The back-arc stratovolcanoes in the southern Havre Trough are situated between deep back-arc rifts to the north and south (Figure 2.1).Wysoczanski et al. (2010) suggested that the observed pattern of juxtaposing back-arc rifts and cross-arc volcanoes and ridges could reflect variations in the addition of subduction components and style of magmatism. They suggested that cross-arc ridges and stratovolcanoes define an 'arc-regime' where magmatism is associated with high melt productivity primarily driven by the addition of subduction slab-derived components, and that the back-arc rifts define a 'rift-regime' where magmatism is associated with small-degree decompression melting, but may also be modified by the addition of subductionderived material. Analyses undertaken on Havre Trough back-arc rift lavas have revealed that they are characterised by subduction-derived components (Todd et al., 2011). However, unlike the Rumble V cross-chain, the trace element compositions of the rift magmas more likely reflect the addition of a supercritical fluid the Havre Trough back-arc mantle source.

Thermal anomalies in the Havre Trough mantle wedge have been proposed to explain variations between the 'rift-regime' and 'arc-regime', (Todd et al., 2010, 2011). Thermal anomalies had also been proposed to account for inferred threedimension thermal variations of the mantle wedge in northeast Japan (i.e. "hot fingers": Tamura et al., 2002). Anomalously high-temperature regions in the mantle 
wedge could result in higher degrees of partial melting required to generate the magma volumes of the cross-arc ridges and back-arc stratovolcanoes. Temperature conditions in these regions are also sufficient for partial melting of subducting sediment, and the subducting slab-derived component would primarily comprise a sediment-derived melt. Todd et al. (2011) suggested that in regions between anomalously thermal regions, temperatures are lower, and the subducting slab-derived component would therefore be dominated by a supercritical fluid associated with lower degrees of partial melting.

Lavas from back-arc stratovolcanoes investigated in this study have trace element patterns that indicate their partial melts were modified by the addition of a sediment melt component. $\mathrm{TiO}_{2}$ contents indicate they are associated with higher degrees of partial melting than back-arc rifts (Kelley et al., 2006). The sediment meltderived subducting component modelled by Todd et al. (2010) to explain Rumble V Ridge compositions can also account for compositions of the back-arc stratovolcano lavas studied here, further north in the southern Havre Trough. The presence of a hot finger/anomalous thermal region in the mantle wedge can explain their rear-arc location in the Havre Trough back-arc, the addition of a sediment-melt subduction component, and the relatively high melt productivity required for construction of arclike edifices. Therefore, the geochemical characteristics of back-arc stratovolcanoes of Gill Seamount and Rapuhia Ridge support earlier hypothesis that they represent another manifestation of an "arc-regime" (Wysoczanski et al., 2010; Todd et al., 2011).

${ }^{40} \mathrm{Ar} /{ }^{39} \mathrm{Ar}$ isotope geochronology and whole rock geochemistry confirm that the back-arc stratovolcanoes in the southern KAHT are associated with present-day subduction at the Tonga-Kermadec margin, and are coeval with volcanism at the Kermadec arc-front. Owing to their rear-arc setting, partial melts are modified by a subduction component that is more comparable to that modifying the Rumble V crosschain than the Kermadec Arc volcanic-front. Although they are characterised by high Or-rich plagioclase compositions that are comparable to those of the Colville Arc, they lack the $\mathrm{K}_{2} \mathrm{O}$-rich alkali-cumulate signature observed in whole rock Colville Arc lavas. $\mathrm{K}_{2} \mathrm{O}$-rich plagioclase has also been observed in the southern Havre Trough (e.g. Rumble II West: Timm et al., 2016), which may indicate the presence of alkali-rich mantle source in the southern Havre Trough. 
Whole rock major element compositions confirm that back-arc volcano magma differentiation is driven primarily by fractional crystallisation. Their magma series defines a tholeiitic evolution trend that follows the same pattern observed in Kermadec Arc front magmas, confirming that constructional arc volcanism can originate in the distal Havre Trough back-arc, and undergo classical volcanic arc-front magma differentiation (Figure 5.10).

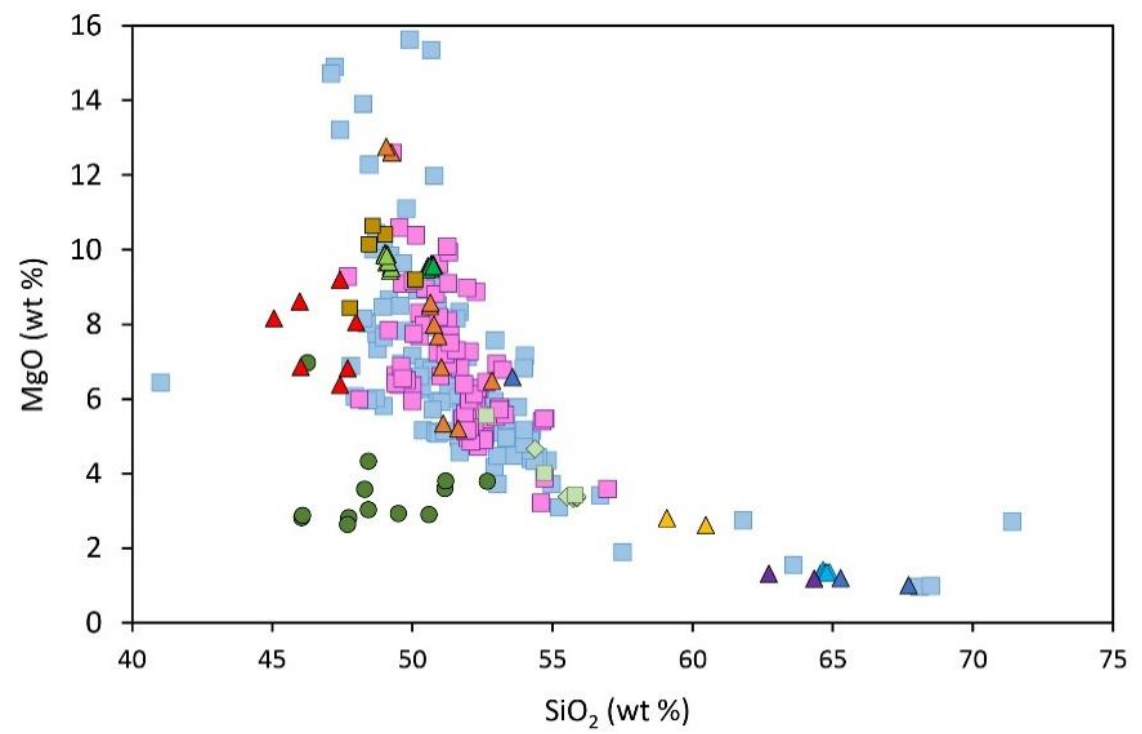

$\square$ Kermadec Arc-front Volcanoes $\square$ Havre Trough Back-arc Basins - Colville Arc Whole Rock Analyses $\diamond$ Colville Arc Glass Analyses $\square$ Colville Arc Olivine-Hosted Melt Inclusions $\triangle$ Gill Seamount (TAN1007-011) $\Delta$ Gill Seamount (TAN1007-012) $\triangle$ Rapuhia Seamount (TAN1007-014) $\triangle$ Rapuhia Seamount (TAN0205-101) $\Delta$ Rapuhia Ridge (TAN1007-015) $\triangle$ Rapuhia Ridge (TAN1007-016) $\Delta$ Yokosuka Seamount (TAN0205-102) $\triangle$ Giljanes Seamount (TAN0205-100) $\square$ Western Havre Trough Back-arc Basins

Figure 5.10. Plot of $\mathrm{MgO}$ (wt \%) versus $\mathrm{SiO}_{2}$ (wt \%), for analyses of samples from Gill Seamount, Rapuhia Ridge, Rapuhia Seamount, Yokosuka Seamount, Giljanes Seamount, Western Havre Trough Back-arc basins, Kermadec Arc-front Volcanoes, Havre Trough Back-arc basins, and the Colville Arc.

\begin{abstract}
All samples are whole rock analyses except for Colville Arc glass analyses and Colville Arc olivine-hosted melt inclusions. Data for whole rock compositions from Kermadec Arc-front volcanoes, Havre Trough Back-arc basins are the same as in (Figure 2.2), and come from Gamble et al. (1990, 1993a, 1993b, 1994, 1996, 1997); Haase et al. (2002); Wysoczanski et al., 2006, 2012; Handler et al. (2011); Timm et al. (2016). Colville Arc whole rock data, glass analyses, and olivine-hosted melt inclusions are unpublished data from Handler pers. comms. (2016).
\end{abstract}




\section{Chapter 6: Conclusions}




\subsection{Key Findings of This Study}

As back-arc stratovolcanoes in the southern Havre Trough were only discovered in recent years, much about their origin and evolution is widely unknown. Data obtained from whole rock major and trace element geochemical data, mineral analyses, and ${ }^{40} \mathrm{Ar} /{ }^{39} \mathrm{Ar}$ isotope ages have provided new insights into their respective magmatic and mantle processes. The following conclusions have been inferred.

1) Young ages associated with recent volcanism. Four samples were selected and prepared for ${ }^{40} \mathrm{Ar} /{ }^{39} \mathrm{Ar}$ isotopic analysis. Two samples obtained from Gill Seamount yielded ages of 1.2 and 0.9 Ma, and two samples selected from Rapuhia Ridge resulted in ages of 105.1 and $49.5 \mathrm{ka}$. All samples analysed are Quaternary in age. These ages are coeval with known ages for volcanoes associated with the Kermadec Arc-front, and the Rumble V Ridge, implying that they are also associated with present-day subduction at the Kermadec Arc. They also comply with the model from Mortimer et al. (2010) that has suggested that arc volcanism in the SW Pacific region has occurred in distinct phases, where the most recent phase is represented by subduction zone magmatism at the Kermadec Arc.

\section{2) Fractional crystallisation as the driving process for magma differentiation. All} the samples collected from back-arc stratovolcanoes investigated in this study are characterised by whole rock major element and trace element compositions, as well as mineral compositions, which indicate that magmas primarily evolved through fractional crystallisation. Whole rock compositions of basaltic magmas from Gill and Rapuhia Ridge display major and trace element patterns that are consistent with fractional crystallisation of olivine and clinopyroxene. Similar trends have been inferred from the compositions of in situ olivine and clinopyroxene phenocrysts, although there is evidence for olivine accumulation in some samples. Analyses of lavas from Rapuhia Seamount, Yokosuka Seamount and Giljanes Seamount are characterised by major and trace element compositions that are consistent with fractional crystallisation of plagioclase, Fe-Ti oxides and apatite. Their more evolved compositions are consistent with prolonged magma differentiation in the thickened region crustal plateau. Intensive parameters calculated from $\mathrm{Fe}-\mathrm{Ti}$ oxide pairs and 
amphibole crystals in Rapuhia Seamount are consistent with crystallisation over a wide range of pressures and temperatures during magma ascent and differentiation.

\section{3) Plagioclase compositions reflect equilibrium crystallisation from different melt}

sources. For a given back-arc volcano lava, in situ analyses of plagioclase crystals from each sample define distinct linear trends with decreasing An contents. Phenocrysts cores, rims and groundmass all follow a similar trend for a given sample, indicating that plagioclase was in equilibrium with the melt at the time of crystallisation. Disequilibrium textures and compositional zoning observed in a given plagioclase crystal in Rapuhia Seamount and Giljanes Seamount lavas are inferred to reflect changes in intensive variables during magma differentiation, such as temperature, pressure, water content and oxygen fugacity. Plagioclase crystals from different back-arc lava suites are characterised by different contents of Or, which is inferred to reflect crystallisation from melts with different $\mathrm{K}_{2} \mathrm{O}$ compositions in the southern Havre Trough.

4) Across-arc variation in the mantle source. Lavas from Gill Seamount and Rapuhia Ridge are characterised by elevated ratios of $\mathrm{Nb} / \mathrm{Yb}$ when compared with Kermadec Arc-front lavas. The observed pattern of increasing $\mathrm{Nb} / \mathrm{Yb}$ with increasing distance from the arc-front could reflect trenchward advection with progressive melt extraction, or that the back-arc volcano partial melts originate from a more fertile mantle source that is less depleted than N-MORB, and gets preferentially melted out during convection. This interpretation remains equivocal.

5) Minor role of aqueous fluid in the subducting slab. Back-arc lavas are characterised by markedly lower ratios of $\mathrm{Ba} / \mathrm{Nb}$ and $\mathrm{Ba} / \mathrm{Th}$ when compared with arc front lavas. The subducting slab is predicted to be $\geq 280 \mathrm{~km}$ deep underneath Gill Seamount, which exceeds the sub-solidus stability threshold for aqueous fluids. Fluid transfer into the mantle source for back-arc stratovolcanoes is inferred to be via supercritical fluids. The presence of enriched LILE concentrations in back-arc lavas confirms that supercritical fluids are transferred from the subducting slab in the Havre Trough back-arc, and modify the partial melts of back-arc stratovolcanoes. However, the extent of fluid enrichment is less than that modifying Kermadec arc-front magmas. 
6) Predominant sediment-derived melt in the subducting slab. Back-arc volcano lavas are characterised by elevated ratios of $(\mathrm{La} / \mathrm{Sm})_{\mathrm{N}}$ compared with most arc-front analyses, suggesting that the subducting component triggering partial melting in their mantle source is a sediment derived component. The trace element patterns of backarc volcano lavas cannot be reconciled via bulk mixing or sediment transfer via a fluid. HFSE/REE fractionations indicates that the slab-derived component modifying backarc volcano magmas is a sediment-derived partial melt, where monazite, zircon and rutile are present as refractory accessory phases. This partial melt is inferred to resemble the subduction component that is also modifying the Rumble V Ridge magmas (e.g. Todd et al., 2010). A possible mechanism for triggering partial melting of subducting sediment is the presence of thermal anomalies in the mantle wedge (e.g. "hot fingers": Tamura et al., 2002), where partial melting of sediment occurs in thermally hot regions, and supercritical fluids are the main subducting component in non-thermally anomalous regions in the mantle wedge (e.g. Todd et al., 2011).

\subsection{Suggestions for Future Work}

This study provides the first detailed geochemical study on back-arc stratovolcanoes in the southern Kermadec Arc-Havre Trough. Partly owing to their submarine nature, the regional setting associated with back-arc stratovolcanoes is poorly explored and sampled in comparison to the Kermadec arc volcanic-front. A wealth of information can be obtained from additional studies undertaken in their regional location in the southern Havre Trough. The data obtained from these backarc stratovolcanoes also raise some intriguing questions. Suggested areas for future research are listed below

1) Magmatic processes would be better constrained by melt inclusion analysis on selected crystals. A number of samples from Gill Seamount and Rapuhia Ridge were found to be characterised by multiple populations of olivine. Analysis of olivine melt inclusions would allow for olivine crystal accumulation processes to be better constrained, and provide insights into estimates of temperature, pressure and water contents as well as degassing histories, associated with back-arc volcano magmas. 
2) Constraining magma differentiation processes associated with dacitic samples from Rapuhia Ridge would be beneficial not only for future understanding of the back-arc volcano magma differentiation, but also for providing new insights into silicic magma genesis in intra-oceanic arcs. While silicic magma differentiation has been investigated in this study, magma genesis has not been quantified in detail. Additional sampling and collection of parental basaltic samples would be beneficial for examining and modelling silicic magma differentiation.

3) The mantle wedge source associated with back-arc volcanoes in the southern Havre Trough is less depleted than the melting source associated with the southern Kermadec arc-front. Constraining the origin of a less depleted mantle is important not only for testing whether there is a systematic relationship between back-arc volcanism and enriched fertile mantle, but also to gain insight into the origin of the Havre Trough ambient mantle wedge. Future sampling and geochemical analysis of back-arc basins, in a variety of locations in the southern Havre Trough, will be a very worthwhile study for constraining mantle heterogeneity in the Havre Trough mantle.

4) The "hot finger" thermal anomaly model proposed by Tamura et al. (2002) has only been speculated to explain the generation of cross-arc chains and back-arc volcanoes in the southern Havre Trough, and has not been investigated or applied in detail. Constraining the thermal structure of the Havre Trough through geophysical surveying will help evaluate the "hot finger" model and determine if it can explain variations between the proposed "rift regime" back-arc rifts and "arc regime" cross-arc chains and volcanoes 


\section{References}

Adams, C., Graham, I., Seward, D., Skinner, D., Adams, C., Skinner, D., and Moore, P., 1994, Geochronological and geochemical evolution of late Cenozoic volcanism in the Coromandel Peninsula, New Zealand: New Zealand Journal of Geology and Geophysics, 37, (3), 359-379.

Ballance, P. F., Ablaev, A. G., Pushchin, I. K., Pletnev, S. P., Birylina, M. G., Itaya, T., Follas, H. A., and Gibson, G. W., 1999, Morphology and history of the Kermadec trench-arc-backarc basin-remnant arc system at 30 to $32 \mathrm{~S}$ : geophysical profile, microfossil and K-Ar data: Marine Geology, 159, (1), 3562.

Bacon, C. R., and Hirschmann, M. M., 1988, Mg/Mn partitioning as a test for equilibrium between coexisting Fe-Ti oxides: American Mineralogist, 73, 5761.

Barker, S. J., 2010, The petrology and genesis of silicic magmas in the Kermadec arc. MSc thesis, Victoria University of Wellington, Wellington, New Zealand.

Barker, S. J., Wilson, C. J. N., Baker, J. A., Millet, M.-A., Rotella, M. D., Wright, I. C., and Wysoczanski, R. J., 2013, Geochemistry and Petrogenesis of Silicic Magmas in the Intra-Oceanic Kermadec Arc: Journal of Petrology, 54, (2), 351391.

Bea, F., and Montero, P., 1999, Behavior of accessory phases and redistribution of $\mathrm{Zr}, \mathrm{REE}, \mathrm{Y}, \mathrm{Th}$, and U during metamorphism and partial melting of metapelites in the lower crust: an example from the Kinzigite Formation of Ivrea-Verbano, NW Italy: Geochimica et Cosmochimica Acta, 63, (7), 1133-1153.

Blundy, J., and Cashman, K., 2008, Petrologic reconstruction of magmatic system variables and processes: Reviews in Mineralogy and Geochemistry, 69, (1), 179239.

Bowen, N. L., 1913, The melting phenomena of the plagioclase feldspars: American Journal of Science, (210), 577-599.

Brenan, J., Shaw, H., Ryerson, F., and Phinney, D., 1995, Mineral-aqueous fluid partitioning of trace elements at $900 \mathrm{C}$ and $2.0 \mathrm{GPa}$ : Constraints on the trace element chemistry of mantle and deep crustal fluids: Geochimica et Cosmochimica Acta, 59, (16), 3331-3350.

Brenan, J. M., Ryerson, F. J., and Shaw, H. F., 1998, The role of aqueous fluids in the slab-to-mantle transfer of boron, beryllium, and lithium during subduction: experiments and models: Geochimica et Cosmochimica Acta, 62, (19-20), 33373347.

Brophy, J. G., 2008, A study of rare earth element (REE)-SiO2 variations in felsic liquids generated by basalt fractionation and amphibolite melting: a potential test for discriminating between the two different processes: Contributions to Mineralogy and Petrology, 156, (3), 337-357. 
Brothers, R., 1967, Andesite from Rumble III volcano, Kermadec ridge, southwest Pacific: Bulletin of Volcanology, 31, (1), 17-19.

Calvert, A. T., Moore, R. B., and McGimsey, R. G., 2005, Argon geochronology of late Pleistocene to Holocene Westdahl Volcano, Unimak Island, Alaska, US Geological Survey.

Campbell, M. E., Rowland, J. V., Wright, I. C., and Smith, I. E., 2007, Oblique rifting along the central and southern Kermadec Arc front (30-36 S), SW Pacific: Geochemistry, Geophysics, Geosystems, 8, (1).

Caress, D. W., 1991, Structural trends and back-arc extension in the Havre Trough: Geophysical Research Letters, 18, (5), 853-856.

Carpentier, M., Chauvel, C., Maury, R. C., and Mattielli, N., 2009, The "zircon effect" as recorded by the chemical and Hf isotopic compositions of Lesser Antilles forearc sediments: Earth and Planetary Science Letters, 287, (1), 86-99.

Carter, L., Carter, R., McCave, I., and Gamble, J., 1996, Regional sediment recycling in the abyssal Southwest Pacific Ocean: Geology, 24, (8), 735-738.

Christie, R. H. K., 2000, The petrology, geochemistry and petrogensis of volcanic rocks in the southern Kermadec Arc, SW Pacific. MSc thesis, Victoria University of Wellington, Wellington, New Zealand.

Conway, C. E., Leonard, G. S., Townsend, D. B., Calvert, A. T., Wilson, C. J. N., Gamble, J. A., and Eaves, S. R., 2016, A high-resolution ${ }^{40} \mathrm{Ar} /{ }^{39} \mathrm{Ar}$ lava chronology and edifice construction history for Ruapehu volcano, New Zealand: Journal of Volcanology and Geothermal Research.

Dalrymple, G., 1989, The GLM continuous laser system for ${ }^{40} \mathrm{Ar} /{ }^{39} \mathrm{Ar}$ dating: Description and performance characteristics: US Geological Survey Bulletin, 1890, 89-96.

Dalrymple, G. B., Alexander, E., Lanphere, M. A., and Kraker, G., 1981, Irradiation of samples for 40Ar/39Ar dating using the Geological Survey TRIGA reactor: USGPO: for sale by the Supt. of Docs., GPO, 2330-7102.

Davy, B., and Collot, J.-Y., 2000, The Rapuhia Scarp (northern Hikurangi Plateau) its nature and subduction effects on the Kermadec Trench: Tectonophysics, 328, (3), 269-295.

Delteil, J., Ruellan, E., Wright, I., and Matsumoto, T., 2002, Structure and structural development of the Havre Trough (SW Pacific): Journal of Geophysical Research: Solid Earth, 107, (B7), ETG 7-1-ETG 7-17.

DeMets, C., Gordon, R. G., Argus, D. F., and Stein, S., 1994, Effect of recent revisions to the geomagnetic reversal time scale on estimates of current plate motions: Geophysical Research Letters, 21, (20), 2191-2194.

DePaolo, D. J., 1981, Trace element and isotopic effects of combined wallrock assimilation and fractional crystallization: Earth and Planetary Science Letters, 53, (2), 189-202.

Dickinson, W. R., and Hatherton, T., 1967, Andesitic volcanism and seismicity around the Pacific: Science, 157, (3790), 801-803.

Duggen, S., Portnyagin, M., Baker, J., Ulfbeck, D., Hoernle, K., Garbe-Schönberg, D., and Grassineau, N., 2007, Drastic shift in lava geochemistry in the volcanicfront to rear-arc region of the Southern Kamchatkan subduction zone: evidence for the transition from slab surface dehydration to sediment melting: Geochimica et Cosmochimica Acta, 71, (2), 452-480. 
Elliott, T., Plank, T., Zindler, A., White, W., and Bourdon, B., 1997, Element transport from slab to volcanic front at the Mariana arc: Journal of Geophysical Research: Solid Earth, 102, (B7), 14991-15019.

Ewart, A., Brothers, R., and Mateen, A., 1977, An outline of the geology and geochemistry, and the possible petrogenetic evolution of the volcanic rocks of the Tonga-Kermadec-New Zealand island arc: Journal of Volcanology and Geothermal Research, 2, (3), 205-250.

Ewart, A., Collerson, K., Regelous, M., Wendt, J., and Niu, Y., 1998, Geochemical evolution within the Tonga-Kermadec-Lau arc-back-arc systems: the role of varying mantle wedge composition in space and time: Journal of Petrology, 39, (3), 331-368.

Fleck, R. J., Hagstrum, J. T., Calvert, A. T., Evarts, R. C., and Conrey, R. M., 2014, ${ }^{40} \mathrm{Ar} /{ }^{39} \mathrm{Ar}$ geochronology, paleomagnetism, and evolution of the Boring volcanic field, Oregon and Washington, USA: Geosphere.

Foley, S. F., Barth, M. G., and Jenner, G. A., 2000, Rutile/melt partition coefficients for trace elements and an assessment of the influence of rutile on the trace element characteristics of subduction zone magmas: Geochimica et Cosmochimica Acta, 64, (5), 933-938.

Furukawa, Y., 1993, Depth of the decoupling plate interface and thermal structure under arcs: Journal of Geophysical Research: Solid Earth, 98, (B11), 20005-20013.

Gamble, J., Smith, I., McCulloch, M., Graham, I., and Kokelaar, B., 1993a, The geochemistry and petrogenesis of basalts from the Taupo Volcanic Zone and Kermadec Island Arc, SW Pacific: Journal of Volcanology and Geothermal Research, 54, (3), 265-290.

Gamble, J., Woodhead, J., Wright, I., and Smith, I., 1996, Basalt and Sediment Geochemistry and Magma Petrogenesis in a Transect from Oceanic Island Arc to Rifted Continental Margin Arc: the Kermadec-Hikurangi Margin, SW Pacific: Journal of Petrology, 37, (6), 1523-1546.

Gamble, J., and Wright, I., 1995, The Southern Havre Trough geological structure and magma petrogenesis of an active backarc rift complex. In: B. Taylor (Editor), Back-arc Basins: Tectonism and Magmatism: Planum Publishing, New York, 29-62.

Gamble, J., Wright, I., and Baker, J., 1993b, Seafloor geology and petrology in the oceanic to continental transition zone of the Kermadec-Havre-Taupo Volcanic Zone arc system, New Zealand: New Zealand Journal of Geology and Geophysics, 36, (4), 417-435.

Gamble, J., Wright, I., Woodhead, J., and McCulloch, M., 1994, Arc and back-arc geochemistry in the southern Kermadec arc-Ngatoro Basin and offshore Taupo Volcanic Zone, SW Pacific: Geological Society, London, Special Publications, 81, (1), 193-212.

Gamble, J., Wright, I., Wysoczanski, R., Todd, E., and McIntosh, W., 2009, Geochemistry, geochronology and tectonic implications of cross-arc ridge volcanism in the Southern Kermadec Arc, SW Pacific (abstract of paper presented at: 19th Annual VM Goldschmidt Conference, Davos, Switzerland, 21-26 June 2009): Geochimica et Cosmochimica Acta, 73, (13, Suppl.), pA409. 
Gamble, J. A., Christie, R. H., Wright, I., and Wysoczanski, R. J., 1997, Primitive Krich magmas from Clark Volcano, southern Kermadec Arc: a paradox in the K depth relationship: Canadian Mineralogist, 35, 275-290.

Gamble, J. A., Smith, I. E., Graham, I. J., Kokelaar, B. P., Cole, J. W., Houghton, B. F., and Wilson, C. J., 1990, The petrology, phase relations and tectonic setting of basalts from the Taupo Volcanic Zone, New Zealand and the Kermadec Island Arc-Havre Trough, SW Pacific: Journal of Volcanology and Geothermal Research, 43, (1), 253-270.

Ghiorso, M. S., and Evans, B. W., 2008, Thermodynamics of rhombohedral oxide solid solutions and a revision of the Fe-Ti two-oxide geothermometer and oxygen-barometer: American Journal of science, 308, (9), 957-1039.

Gill, J., 1981, Orogenic andesites and plate tectonics Berlin, Springer-Verlag.

Graham, I. J., Reyes, A. G., Wright, I. C., Peckett, K. M., Smith, I. E., and Arculus, R. J., 2008, Structure and petrology of newly discovered volcanic centers in the northern Kermadec-southern Tofua arc, South Pacific Ocean: Journal of Geophysical Research: Solid Earth, 113, (B8).

Haase, K. M., Stroncik, N., Garbe-Schönberg, D., and Stoffers, P., 2006, Formation of island arc dacite magmas by extreme crystal fractionation: an example from Brothers Seamount, Kermadec island arc (SW Pacific): Journal of Volcanology and Geothermal Research, 152, (3), 316-330.

Haase, K. M., Worthington, T. J., Stoffers, P., Garbe-Schönberg, D., and Wright, I., 2002, Mantle dynamics, element recycling, and magma genesis beneath the Kermadec Arc-Havre Trough: Geochemistry, Geophysics, Geosystems, 3, (11), 122.

Handler, M., Wysoczanski, R., and Burger, E., 2011, Evolution of a Mantle Wedge: Basalts from the Colville and Kermadec Ridges (abstract presented at: 21st Annual VM Goldschmidt Conference, Prague, Czech Republic, August 1419, 2011): Mineralogical Magazine, 75, (3), 974.

Hattori, K. H., and Guillot, S., 2003, Volcanic fronts form as a consequence of serpentinite dehydration in the forearc mantle wedge: Geology, 31, (6), 525528.

Hawkesworth, C., Turner, S., McDermott, F., Peate, D., and Van Calsteren, P., 1997, U-Th isotopes in arc magmas: Implications for element transfer from the subducted crust: Science, 276, (5312), 551-555.

Hawthorne, F. C., Oberti, R., Harlow, G. E., Maresch, W. V., Martin, R. F., Schumacher, J. C., and Welch, M. D., 2012, Nomenclature of the amphibole supergroup: American Mineralogist, 97, (11-12), 2031-2048.

Herbert, K. R., 2013, Temporal distribution and frequency of explosive volcanism in the Kermadec Arc, SW Pacific: Insights from marine cores.

Hermann, J., and Rubatto, D., 2009, Accessory phase control on the trace element signature of sediment melts in subduction zones: Chemical Geology, 265, (3), 512-526.

Hermann, J., Spandler, C., Hack, A., and Korsakov, A. V., 2006, Aqueous fluids and hydrous melts in high-pressure and ultra-high pressure rocks: implications for element transfer in subduction zones: Lithos, 92, (3), 399-417. 
Herzer, R. H., 1995, Seismic stratigraphy of a buried volcanic arc, Northland, New Zealand and implications for Neogene subduction: Marine and Petroleum Geology, 12, (5), 511-531.

Hochstaedter, A., Gill, J., Peters, R., Broughton, P., Holden, P., and Taylor, B., 2001, Across-arc geochemical trends in the Izu-Bonin arc: Contributions from the subducting slab: Geochemistry, Geophysics, Geosystems, 2, (7).

Hochstaedter, A. G., Gill, J. B., Taylor, B., Ishizuka, O., Yuasa, M., and Monta, S., 2000, Across-arc geochemical trends in the Izu-Bonin arc: Constraints on source composition and mantle melting: Journal of Geophysical Research: Solid Earth, 105, (B1), 495-512.

Honda, S., Gerya, T., and Zhu, G., 2010, A simple three-dimensional model of thermo-chemical convection in the mantle wedge: Earth and Planetary Science Letters, 290, (3-4), 311-318.

Honda, S., and Saito, M., 2003, Small-scale convection under the back-arc occurring in the low viscosity wedge: Earth and Planetary Science Letters, 216, (4), 703715.

Housh, T. B., and Luhr, J. F., 1991, Plagioclase-melt equilibria in hydrous systems: American Mineralogist, 76, (3-4), 477-492.

Hussong, D. M., and Fryer, P., 1983, Back-arc seamounts and the SeaMARC II seafloor mapping system: Eos, Transactions American Geophysical Union, 64, (45), 627-632.

Ingamells, C., 1980, Analyzed minerals for electron microprobe standards: Geostandards Newsletter, 2, (2), 115-115.

Iwamori, H., 1998, Transportation of $\mathrm{H} 2 \mathrm{O}$ and melting in subduction zones: Earth and Planetary Science Letters, 160, (1), 65-80.

Jarosewich, E., Nelen, J., and NORBERG, J. A., 1980, Reference samples for electron microprobe analysis: Geostandards Newsletter, 4, (1), 43-47.

Jochum, K. P., and Nohl, U., 2008, Reference materials in geochemistry and environmental research and the GeoReM database: Chemical Geology, 253, (12), 50-53.

Jochum, K. P., Weis, U., Schwager, B., Stoll, B., Wilson, S. A., Haug, G. H., Andreae, M. O., and Enzweiler, J., 2016, Reference Values Following ISO Guidelines for Frequently Requested Rock Reference Materials: Geostandards and Geoanalytical Research, 40, (3), 333-350.

Johnson, M. C., and Plank, T., 2000, Dehydration and melting experiments constrain the fate of subducted sediments: Geochemistry, Geophysics, Geosystems, 1, (12).

Karig, D. E., 1970, Ridges and basins of the Tonga-Kermadec island arc system: Journal of Geophysical Research, 75, (2), 239-254.

Kelemen, P. B., Shimizu, N., and Dunn, T., 1993, Relative depletion of niobium in some arc magmas and the continental crust: partitioning of $\mathrm{K}, \mathrm{Nb}$, $\mathrm{La}$ and $\mathrm{Ce}$ during melt/rock reaction in the upper mantle: Earth and Planetary Science Letters, 120, (3), 111-134.

Kelley, K. A., Plank, T., Grove, T. L., Stolper, E. M., Newman, S., and Hauri, E., 2006, Mantle melting as a function of water content beneath back-arc basins: Journal of Geophysical Research: Solid Earth, 111, (B9).

Keppler, H., 1996, Constraints from partitioning experiments on the composition of subduction-zone fluids: Nature, 380, (237-240). 
Kessel, R., Schmidt, M. W., Ulmer, P., and Pettke, T., 2005, Trace element signature of subduction-zone fluids, melts and supercritical liquids at $120-180 \mathrm{~km}$ depth: Nature, 437, (7059), 724-727.

Klemme, S., Prowatke, S., Hametner, K., and Günther, D., 2005, Partitioning of trace elements between rutile and silicate melts: implications for subduction zones: Geochimica et Cosmochimica Acta, 69, (9), 2361-2371.

Klügel, A., Hansteen, T. H., and Galipp, K., 2005, Magma storage and underplating beneath Cumbre Vieja volcano, la Palma (Canary Islands): Earth and Planetary Science Letters, 236, (1), 211-226.

Le Bas, M. J., Le Maitre, R., Streckeisen, A., and Zanettin, B., 1986, A chemical classification of volcanic rocks based on the total alkali-silica diagram: Journal of Petrology, 27, (3), 745-750.

Leat, P. T., Smellie, J. L., Millar, I. L., and Larter, R. D., 2003, Magmatism in the South Sandwich arc: Geological Society, London, Special Publications, 219, (1), 285-313.

Lepage, L.D., 2003. ILMAT: an excel worksheet for ilmenite-magnetite geothermometry and geobarometry: Computers $\mathcal{E}$ Geosciences, 29, (5), 673678.

Lloyd, E. F., and Nathan, S., 1981, Geology and tephrochronology of Raoul Island, Kermadec Group, New Zealand, New Zealand Geological Society Bulletin, 95.

Locock, A. J., 2014, An Excel spreadsheet to classify chemical analyses of amphiboles following the IMA 2012 recommendations: Computers $\mathcal{E}$ Geosciences, 62, 1-11.

Machida, S., and Ishii, T., 2003, Backarc volcanism along the en echelon seamounts: The Enpo seamount chain in the northern Izu-Ogasawara arc: Geochemistry, Geophysics, Geosystems, 4, (8).

Machida, S., Ishii, T., Kimura, J. I., Awaji, S., and Kato, Y., 2008, Petrology and geochemistry of cross-chains in the Izu-Bonin back arc: Three mantle components with contributions of hydrous liquids from a deeply subducted slab: Geochemistry, Geophysics, Geosystems, 9, (5).

Malahoff, A., Feden, R. H., and Fleming, H. S., 1982, Magnetic anomalies and tectonic fabric of marginal basins north of New Zealand: Journal of Geophysical Research: Solid Earth, 87, (B5), 4109-4125.

Martínez, F., Fryer, P., Baker, N. A., and Yamazaki, T., 1995, Evolution of backarc rifting: Mariana Trough, 20-24 N: Journal of Geophysical Research: Solid Earth, 100, (B3), 3807-3827.

Martinez, F., and Taylor, B., 2003, Controls on back-arc crustal accretion: insights from the Lau, Manus and Mariana basins: Geological Society, London, Special Publications, 219, (1), 19-54.

Martinez, F., and Taylor, B., 2006, Modes of crustal accretion in back-arc basins: Inferences from the Lau Basin. In: Back-arc spreading systems: geological, biological, chemical, and physical interactions, American Geophysical Union, Geophysical Monograph, 166, 5-30.

McCulloch, M. T., and Gamble, J., 1991, Geochemical and geodynamical constraints on subduction zone magmatism: Earth and Planetary Science Letters, 102, (3), 358-374. 
McDonough, W. F., and Sun, S.-S., 1995, The composition of the Earth: Chemical Geology, 120, (3), 223-253.

McDougall, I., and Harrison, T. M., 1999, Geochronology and Thermochronology by the ${ }^{40} \mathrm{Ar} /{ }^{39} \mathrm{Ar}$ Method, Oxford University Press on Demand.

Mibe, K., Fujii, T., and Yasuda, A., 1999, Control of the location of the volcanic front in island arcs by aqueous fluid connectivity in the mantle wedge: Nature, $401,(6750), 259-262$.

Miyashiro, A., 1974, Volcanic rock series in island arcs and active continental margins: American Journal of Science, 274, (4), 321-355.

Miyashiro, A., 1978, Nature of alkalic volcanic rock series: Contributions to Mineralogy and Petrology, 66, (1), 91-104.

Mortimer, N., Gans, P., Palin, J., Meffre, S., Herzer, R., and Skinner, D., 2010, Location and migration of Miocene-Quaternary volcanic arcs in the SW Pacific region: Journal of Volcanology and Geothermal Research, 190, (1), 1-10.

Mortimer, N., Herzer, R., Gans, P., Laporte-Magoni, C., Calvert, A., and Bosch, D., 2007, Oligocene-Miocene tectonic evolution of the South Fiji Basin and Northland Plateau, SW Pacific Ocean: Evidence from petrology and dating of dredged rocks: Marine Geology, 237, (1), 1-24.

Nichols, G. T., Wyllie, P. J., and Stern, C. R., 1994, Subduction zone melting of pelagic sediments constrained by melting experiments: Nature, 371, (6500), 785-788.

Parson, L., Pearce, J. A., Murton, B., and Hodkinson, R., 1990, Role of ridge jumps and ridge propagation in the tectonic evolution of the Lau back-arc basin, southwest Pacific: Geology, 18, (5), 470-473.

Parson, L., Rothwell, R., and MacLeod, C., 1994, Tectonics and sedimentation in the Lau Basin (southwest Pacific). In: Proceedings Proceedings of the Ocean Drilling Program, Scientific Results, 135, 9-21.

Parson, L., and Wright, I., 1996, The Lau-Havre-Taupo back-arc basin: A southward-propagating, multi-stage evolution from rifting to spreading: Tectonophysics, 263, (1), 1-22.

Peacock, S. M., and Wang, K., 1999, Seismic consequences of warm versus cool subduction metamorphism: Examples from southwest and northeast Japan: Science, 286, (5441), 937-939.

Pearce, J. A., 2008, Geochemical fingerprinting of oceanic basalts with applications to ophiolite classification and the search for Archean oceanic crust: Lithos, $100,(1), 14-48$.

Pearce, J. A., Kempton, P. D., Nowell, G. M., and Noble, S. R., 1999, Hf-Nd Element and Isotope Perspective on the Nature and Provenance of Mantle and Subduction Components in Western Pacific Arc-Basin Systems: Journal of Petrology, 40, (11), 1579-1611.

Pearce, J. A., and Peate, D. W., 1995, Tectonic implications of the composition of volcanic arc magmas: Annual Reviews of Earth and Planetary Sciences, 23, 251285.

Pearce, J. A., and Stern, R. J., 2006, Origin of back-arc basin magmas: Trace element and isotope perspectives: Back-Arc Spreading Systems: Geological, Biological, Chemical, and Physical Interactions, 63-86. 
Pearce, J. A., Stern, R. J., Bloomer, S. H., and Fryer, P., 2005, Geochemical mapping of the Mariana arc-basin system: Implications for the nature and distribution of subduction components: Geochemistry, Geophysics, Geosystems, 6, (7).

Plank, T., 2005, Constraints from thorium/lanthanum on sediment recycling at subduction zones and the evolution of the continents: Journal of Petrology, 46, (5), 921-944.

Plank, T., and Langmuir, C. H., 1998, The chemical composition of subducting sediment and its consequences for the crust and mantle: Chemical Geology, 145, (3), 325-394.

Portnyagin, M., Hoernle, K., Plechov, P., Mironov, N., and Khubunaya, S., 2007, Constraints on mantle melting and composition and nature of slab components in volcanic arcs from volatiles $(\mathrm{H} 2 \mathrm{O}, \mathrm{S}, \mathrm{Cl}, \mathrm{F})$ and trace elements in melt inclusions from the Kamchatka Arc: Earth and Planetary Science Letters, 255, (1), 53-69.

Ramsey, M. H., Potts, P. J., Webb, P. C., Watkins, P., Watson, J. S., and Coles, B. J., 1995, An objective assessment of analytical method precision: comparison of ICP-AES and XRF for the analysis of silicate rocks: Chemical Geology, 124, (1), 1-19.

Regelous, M., Collerson, K., Ewart, A., and Wendt, J., 1997, Trace element transport rates in subduction zones: evidence from $\mathrm{Th}, \mathrm{Sr}$ and $\mathrm{Pb}$ isotope data for Tonga-Kermadec arc lavas: Earth and Planetary Science Letters, 150, (3), 291302.

Ridolfi, F., Renzulli, A., and Puerini, M., 2010, Stability and chemical equilibrium of amphibole in calc-alkaline magmas: an overview, new thermobarometric formulations and application to subduction-related volcanoes: Contributions to Mineralogy and Petrology, 160, (1), 45-66.

Roeder, P., and Emslie, R., 1970, Olivine-liquid equilibrium: Contributions to Mineralogy and Petrology, 29, (4), 275-289.

Rubatto, D., and Hermann, J., 2007, Experimental zircon/melt and zircon/garnet trace element partitioning and implications for the geochronology of crustal rocks: Chemical Geology, 241, (1-2), 38-61.

Rudnick, R. L., Barth, M., Horn, I., and McDonough, W. F., 2000, Rutile-bearing refractory eclogites: missing link between continents and depleted mantle: Science, 287, (5451), 278-281.

Ruellan, E., Delteil, J., Wright, I., and Matsumoto, T., 2003, From rifting to active spreading in the Lau Basin-Havre Trough backarc system (SW Pacific): Locking/unlocking induced by seamount chain subduction: Geochemistry, Geophysics, Geosystems, 4, (5).

Rüpke, L. H., Morgan, J. P., Hort, M., and Connolly, J. A., 2004, Serpentine and the subduction zone water cycle: Earth and Planetary Science Letters, 223, (1), 1734.

Ryan, J. G., Morris, J., Tera, F., Leeman, W. P., and Tsvetkov, A., 1995, Cross-arc geochemical variations in the Kurile arc as a function of slab depth: Science, 270, (5236), 625.

Sauerzapf, U., Lattard, D., Burchard, M., and Engelmann, R., 2008, The titanomagnetite-ilmenite equilibrium: new experimental data and thermo- 
oxybarometric application to the crystallization of basic to intermediate rocks: Journal of Petrology, 49, (6), 1161-1185.

Saunders, K., Baker, J., and Wysoczanski, R., 2010, Microanalysis of large volume silicic magma in continental and oceanic arcs: Melt inclusions in Taupo Volcanic Zone and Kermadec Arc rocks, South West Pacific: Journal of Volcanology and Geothermal Research, 190, (1), 203-218.

Schellart, W., Lister, G., and Toy, V., 2006, A Late Cretaceous and Cenozoic reconstruction of the Southwest Pacific region: tectonics controlled by subduction and slab rollback processes: Earth-Science Reviews, 76, (3), 191233.

Schmidt, M. W., and Poli, S., 1998, Experimentally based water budgets for dehydrating slabs and consequences for arc magma generation: Earth and Planetary Science Letters, 163, (1), 361-379.

Skora, S., and Blundy, J., 2010, High-pressure hydrous phase relations of radiolarian clay and implications for the involvement of subducted sediment in arc magmatism: Journal of Petrology, 51, (11), 2211-2243.

Smith, I., and Brothers, R., 1988, Petrology of the Rumble seamounts, southern Kermadec Ridge, southwest Pacific: Bulletin of Volcanology, 50, (3), 139-147.

Smith, I. E., and Price, R. C., 2006, The Tonga-Kermadec arc and Havre-Lau backarc system: their role in the development of tectonic and magmatic models for the western Pacific: Journal of Volcanology and Geothermal Research, 156, (3), 315-331.

Smith, I. E. M., Worthington, T. J., Price, R. C., Stewart, R. B., and Maas, R., 2006, Petrogenesis of dacite in an oceanic subduction environment: Raoul Island, Kermadec arc: Journal of Volcanology and Geothermal Research, 156, (3), 252265.

Smith, I. E. M., Stewart, R. B., and Price, R. C., 2003, The petrology of a large intraoceanic silicic eruption: the Sandy Bay Tephra, Kermadec Arc, Southwest Pacific: Journal of Volcanology and Geothermal Research, 124, (3-4), 173-194.

Sobolev, A. V., and Danyushevsky, L. V., 1994, Petrology and geochemistry of boninites from the north termination of the Tonga Trench: constraints on the generation conditions of primary high-Ca boninite magmas: Journal of Petrology, 35, (5), 1183-1211.

Stern, R. J., Jackson, M. C., Fryer, P., and Ito, E., 1993, O, Sr, Nd and Pb isotopic composition of the Kasuga Cross-Chain in the Mariana Arc: A new perspective on the K-h relationship: Earth and Planetary Science Letters, 119, (4), 459-475.

Stern, R. J., Kohut, E., Bloomer, S. H., Leybourne, M., Fouch, M., and Vervoort, J., 2006, Subduction factory processes beneath the Guguan cross-chain, Mariana Arc: no role for sediments, are serpentinites important?: Contributions to Mineralogy and Petrology, 151, (2), 202-221.

Stern, R. J., Tamura, Y., Ishizuka, O., Shukano, H., Bloomer, S. H., Embley, R. W., Leybourne, M., Kawabata, H., Nunokawa, A., and Nichols, A. R., 2014, Volcanoes of the Diamante cross-chain: evidence for a mid-crustal felsic magma body beneath the Southern Izu-Bonin-Mariana arc: Geological Society, London, Special Publications, 385, (1), 235-255. 
Sun, S.-S., and McDonough, W. F., 1989, Chemical and isotopic systematics of oceanic basalts: implications for mantle composition and processes. In: Saunders, A. D. and Norry, M. J. (editors), Magmatism in the Ocean Basins: Geological Society, London, Special Publications, 42, (1), 313-345.

Syracuse, E. M., and Abers, G. A., 2006, Global compilation of variations in slab depth beneath arc volcanoes and implications: Geochemistry, Geophysics, Geosystems, 7, (5).

Syracuse, E. M., van Keken, P. E., and Abers, G. A., 2010, The global range of subduction zone thermal models: Physics of the Earth and Planetary Interiors, 183, (1), 73-90.

Tamura, Y., Gill, J. B., Tollstrup, D., Kawabata, H., Shukuno, H., Chang, Q., Miyazaki, T., Takahashi, T., Hirahara, Y., and Kodaira, S., 2009, Silicic magmas in the Izu-Bonin oceanic arc and implications for crustal evolution: Journal of Petrology, 50, (4), 685-723.

Tamura, Y., and Tatsumi, Y., 2002, Remelting of an andesitic crust as a possible origin for rhyolitic magma in oceanic arcs: an example from the Izu-Bonin arc: Journal of Petrology, 43, (6), 1029-1047.

Tamura, Y., Tatsumi, Y., Zhao, D., KIDO, Y., and SHUKUNO, H., 2001, Distribution of Quaternary volcanoes in the Northeast Japan arc: Proceedings of the Japan Academy, Series B, 77, (7), 135-139.

Tamura, Y., Tatsumi, Y., Zhao, D., Kido, Y., and Shukuno, H., 2002, Hot fingers in the mantle wedge: new insights into magma genesis in subduction zones: Earth and Planetary Science Letters, 197, (1), 105-116.

Tani, K., Kawabata, H., Qing, C., Sato, K., and Tastumi, Y., 2005, Quantitative analyses of silicate rock major and trace elements by X-ray fluorescence spectrometer: Evaluation of analytical precision and sample preparation: Frontier Research on Earth Evolution, 2, 1-8.

Tani, K., Fiske, R. S., Tamura, Y., Kido, Y., Naka, J., Shukuno, H., and Takeuchi, R., 2008, Sumisu volcano, Izu-Bonin arc, Japan: site of a silicic caldera-forming eruption from a small open-ocean island: Bulletin of Volcanology, 70, (5), 547562.

Tatsumi, Y., 1989, Migration of fluid phases and genesis of basalt magmas in subduction zones: Journal of Geophysical Research: Solid Earth, 94, (B4), 46974707.

Tatsumi, Y., 2001, Geochemical modeling of partial melting of subducting sediments and subsequent melt-mantle interaction: Generation of high-Mg andesites in the Setouchi volcanic belt, southwest Japan: Geology, 29, (4), 323326.

Tatsumi, Y., Hamilton, D., and Nesbitt, R., 1986, Chemical characteristics of fluid phase released from a subducted lithosphere and origin of arc magmas: evidence from high-pressure experiments and natural rocks: Journal of Volcanology and Geothermal Research, 29, (1), 293-309.

Tatsumi, Y., Sakuyama, M., Fukuyama, H., and Kushiro, I., 1983, Generation of arc basalt magmas and thermal structure of the mantle wedge in subduction zones: Journal of Geophysical Research: Solid Earth, 88, (B7), 5815-5825.

Taylor, B., Rifting and the volcanic-tectonic evolution of the Izu-Bonin-Mariana arc, in Proceedings Proceedings of the Ocean Drilling Program, Scientific 
Results1992, Volume 126, Ocean Drilling Program College Station Texas, p. 627-651.

Taylor, B., and Martinez, F., 2003, Back-arc basin basalt systematics: Earth and Planetary Science Letters, 210, (3), 481-497.

Taylor, B., Zellmer, K., Martinez, F., and Goodliffe, A., 1996, Sea-floor spreading in the Lau back-arc basin: Earth and Planetary Science Letters, 144, (1), 35-40.

Timm, C., Bassett, D., Graham, I. J., Leybourne, M. I., de Ronde, C. E., Woodhead, J., Layton-Matthews, D., and Watts, A. B., 2013, Louisville seamount subduction and its implication on mantle flow beneath the central TongaKermadec arc: Nature Communications, 4, 1720.

Timm, C., Davy, B., Haase, K., Hoernle, K. A., Graham, I. J., de Ronde, C. E. J., Woodhead, J., Bassett, D., Hauff, F., Mortimer, N., Seebeck, H. C., Wysoczanski, R. J., Caratori-Tontini, F., and Gamble, J. A., 2014, Subduction of the oceanic Hikurangi Plateau and its impact on the Kermadec arc: Nature Communications, 5, 4923.

Timm, C., Graham, I. J., de Ronde, C. E., Leybourne, M. I., and Woodhead, J., 2011, Geochemical evolution of Monowai volcanic center: New insights into the northern Kermadec arc subduction system, SW Pacific: Geochemistry, Geophysics, Geosystems, 12, (8).

Timm, C., Leybourne, M. I., Hoernle, K., Wysoczanski, R. J., Hauff, F., Handler, M., Tontini, F. C., and de Ronde, C. E., 2016, Trench-perpendicular Geochemical Variation Between two Adjacent Kermadec Arc Volcanoes Rumble II East and West: the Role of the Subducted Hikurangi Plateau in Element Recycling in Arc Magmas: Journal of Petrology, 57, (7), 1335-1360.

Todd, E., Gill, J., Wysoczanski, R., Handler, M. R., Wright, I., and Gamble, J., 2010, Sources of constructional cross-chain volcanism in the southern Havre Trough: New insights from HFSE and REE concentration and isotope systematics: Geochemistry, Geophysics, Geosystems, 11, (4).

Todd, E., Gill, J., Wysoczanski, R. J., Hergt, J., Wright, I. C., Leybourne, M. I., and Mortimer, N., 2011, Hf isotopic evidence for small-scale heterogeneity in the mode of mantle wedge enrichment: Southern Havre Trough and South Fiji Basin back arcs: Geochemistry, Geophysics, Geosystems, 12, (9).

Tollstrup, D., Gill, J., Kent, A., Prinkey, D., Williams, R., Tamura, Y., and Ishizuka, O., 2010, Across-arc geochemical trends in the Izu-Bonin arc: Contributions from the subducting slab, revisited: Geochemistry, Geophysics, Geosystems, 11, (1).

Tollstrup, D. L., and Gill, J. B., 2005, Hafnium systematics of the Mariana arc: Evidence for sediment melt and residual phases: Geology, 33, (9), 737-740.

Turner, S., Hawkesworth, C., Rogers, N., Bartlett, J., Worthington, T., Hergt, J., Pearce, J., and Smith, I., 1997, 238U-230Th disequilibria, magma petrogenesis, and flux rates beneath the depleted Tonga-Kermadec island arc: Geochimica et Cosmochimica Acta, 61, (22), 4855-4884.

Van der Hilst, R., 1995, Complex morphology of subducted lithosphere in the mantle beneath the Tonga trench: Nature, 374, 154-157.

Wallace, P. J., 2005, Volatiles in subduction zone magmas: concentrations and fluxes based on melt inclusion and volcanic gas data: Journal of Volcanology and Geothermal Research, 140, (1-3), 217-240. 
Wallace, L., Reyners, M., Cochran, U., Bannister, S., Barnes, P. M., Berryman, K., Downes, G., Eberhart-Phillips, D., Fagereng, A., Ellis, S., Nicol, A., McCaffrey, R., Beaven, R. J., Henrys, S., Sutherland, R., Barker, D. H. N., Litchfield, N., Townend, J., Robinson, R., Bell, R., Wilson, K. \& Power, W., 2009, Characterizing the seismogenic zone of a major plate boundary subduction thrust: Hikurangi Margin, New Zealand: Geochemistry, Geophysics, Geosystems, 10, (10).

Weissel, J., Reading, H., and Stegena, L., 1981, Magnetic Lineations in Marginal Basins of the Western Pacific [and Discussion]: Philosophical Transactions of the Royal Society of London A: Mathematical, Physical and Engineering Sciences, 300, (1454), 223-247.

Wilson, C., Houghton, B., McWilliams, M., Lanphere, M., Weaver, S., and Briggs, R., 1995, Volcanic and structural evolution of Taupo Volcanic Zone, New Zealand: a review: Journal of Volcanology and Geothermal Research, 68, (1), 1-28.

Woodhead, J., Eggins, S., and Gamble, J., 1993, High field strength and transition element systematics in island arc and back-arc basin basalts: evidence for multi-phase melt extraction and a depleted mantle wedge: Earth and Planetary Science Letters, 114, (4), 491-504.

Woodhead, J., Hergt, J., Davidson, J., and Eggins, S., 2001, Hafnium isotope evidence for 'conservative' element mobility during subduction zone processes: Earth and Planetary Science Letters, 192, (3), 331-346.

Woodhead, J., Stern, R. J., Pearce, J., Hergt, J., and Vervoort, J., 2012, Hf-Nd isotope variation in Mariana Trough basalts: The importance of "ambient mantle" in the interpretation of subduction zone magmas: Geology, 40, (6), 539-542.

Workman, R. K., and Hart, S. R., 2005, Major and trace element composition of the depleted MORB mantle (DMM): Earth and Planetary Science Letters, 231, (1), 53-72.

Wright, I., 1993, Pre-spread rifting and heterogeneous volcanism in the southern Havre Trough back-arc basin: Marine Geology, 113, (3), 179-200.

Wright, I., 1994, Nature and tectonic setting of the southern Kermadec submarine arc volcanoes: An overview: Marine Geology, 118, (3), 217-236.

Wright, I., Parson, L., and Gamble, J., 1996, Evolution and interaction of migrating cross-arc volcanism and backarc rifting: An example from the southern Havre Trough (35 20'-37 S): Journal of Geophysical Research: Solid Earth, 101, (B10), 22071-22086.

Wright, I., Worthington, T., and Gamble, J., 2006, New multibeam mapping and geochemistry of the 30-35 S sector, and overview, of southern Kermadec arc volcanism: Journal of Volcanology and Geothermal Research, 149, (3), 263-296.

Wright, I. C., 1997, Morphology and evolution of the remnant Colville and active Kermadec arc ridges south of 33 30' S: Marine Geophysical Researches, 19, (2), 177-193.

Wysoczanski, R., and Clark, M., 2012, Southern Kermadec Arc-Havre Trough Geohabitats and Biological Communities, in Harris, P., and EK, B., eds., Seafloor Geomorphology as a Benthic Habitat: London, Elsevier, p. 853-867. Wysoczanski, R., Handler, M., Schipper, C., Leybourne, M., Creech, J., Rotella, M., Nichols, A., Wilson, C., and Stewart, R., 2012, The tectonomagmatic source 
of ore metals and volatile elements in the southern Kermadec arc: Economic Geology, 107, (8), 1539-1556.

Wysoczanski, R., Todd, E., Wright, I., Leybourne, M., Hergt, J., Adam, C., and Mackay, K., 2010, Backarc rifting, constructional volcanism and nascent disorganised spreading in the southern Havre Trough backarc rifts (SW Pacific): Journal of Volcanology and Geothermal Research, 190, (1), 39-57.

Wysoczanski, R., Wright, I., Gamble, J. A., Hauri, E., Luhr, J., Eggins, S., and Handler, M., 2006, Volatile contents of Kermadec Arc-Havre Trough pillow glasses: fingerprinting slab-derived aqueous fluids in the mantle sources of arc and back-arc lavas: Journal of Volcanology and Geothermal Research, 152, (1), 51-73.

York, D., 1968, Least squares fitting of a straight line with correlated errors: Earth and Planetary Science Letters, 5, 320-324. 


\section{Appendix A1: Sample Information}




\begin{tabular}{|c|c|c|c|c|c|c|}
\hline Sample Number & Dredge & Location & XRF & ICP-MS & EPMA & $\begin{array}{l}{ }^{40} \mathrm{Ar} /{ }^{39} \mathrm{Ar} \\
\text { Analysis }\end{array}$ \\
\hline TAN1007-011-01 & TAN1007-011 & Gill (flank) & $\mathrm{X}$ & $\mathrm{X}$ & & \\
\hline TAN1007-011-02 & & & $\mathrm{X}$ & $\mathrm{X}$ & $\mathrm{X}$ & \\
\hline TAN1007-011-03 & & & $\mathrm{X}$ & $\mathrm{X}$ & & \\
\hline TAN1007-011-04 & & & $\mathrm{X}$ & $\mathrm{X}$ & $\mathrm{X}$ & $\mathrm{X}$ \\
\hline TAN1007-011-05 & & & $\mathrm{x}$ & $\mathrm{X}$ & & \\
\hline TAN1007-011-06 & & & $\mathrm{X}$ & $\mathrm{X}$ & $\mathrm{X}$ & \\
\hline TAN1007-011-09 & & & $\mathrm{X}$ & $\mathrm{X}$ & & \\
\hline TAN1007-011-10 & & & $\mathrm{X}$ & $\mathrm{X}$ & & \\
\hline TAN1007-011-11 & & & $\mathrm{X}$ & $\mathrm{X}$ & & \\
\hline TAN1007-012-01 & TAN1007-011 & Gill (summit) & $\mathrm{X}$ & $\mathrm{X}$ & $\mathrm{X}$ & $\mathrm{X}$ \\
\hline TAN1007-012-02 & & & $\mathrm{X}$ & $\mathrm{X}$ & & \\
\hline TAN1007-012-02x & & & $\mathrm{X}$ & $\mathrm{X}$ & & \\
\hline TAN1007-012-03 & & & $\mathrm{X}$ & $\mathrm{X}$ & $\mathrm{X}$ & \\
\hline TAN1007-012-05 & & & $\mathrm{X}$ & $\mathrm{X}$ & & \\
\hline TAN1007-012-07 & & & $\mathrm{X}$ & $\mathrm{X}$ & & \\
\hline TAN1007-012-08 & & & $\mathrm{X}$ & $\mathrm{X}$ & $\mathrm{X}$ & \\
\hline TAN1007-015-03 & TAN1007-015 & Rapuhia Ridge & $\mathrm{X}$ & & $\mathrm{X}$ & \\
\hline TAN1007-015-04 & & & $\mathrm{X}$ & & $\mathrm{X}$ & $\mathrm{X}$ \\
\hline TAN1007-015-05 & & & $\mathrm{X}$ & & & \\
\hline TAN1007-015-06 & & & $\mathrm{X}$ & & & \\
\hline TAN1007-015-07 & & & $\mathrm{X}$ & & & \\
\hline TAN1007-015-08 & & & $\mathrm{X}$ & & & \\
\hline TAN1007-015-09 & & & $\mathrm{X}$ & & & \\
\hline TAN1007-015-10 & & & $\mathrm{X}$ & & & \\
\hline TAN1007-016-01 & TAN1007-016 & Rapuhia Ridge & $\mathrm{X}$ & & $\mathrm{X}$ & $\mathrm{X}$ \\
\hline TAN1007-016-02 & & & $\mathrm{X}$ & & & \\
\hline TAN1007-016-03 & & & $\mathrm{X}$ & & $\mathrm{X}$ & \\
\hline TAN1007-016-04 & & & $\mathrm{X}$ & & & \\
\hline TAN1007-016-05 & & & $\mathrm{X}$ & & & \\
\hline TAN1007-016-06 & & & $\mathrm{X}$ & & & \\
\hline TAN1007-016-07 & & & $\mathrm{X}$ & & & \\
\hline TAN1007-016-08 & & & $\mathrm{X}$ & & & \\
\hline TAN1007-016-09 & & & $\mathrm{X}$ & & & \\
\hline TAN1007-014-01 & TAN1007-014 & Rapuhia & $\mathrm{X}$ & $\mathrm{X}$ & & \\
\hline TAN1007-014-02 & & & $\mathrm{X}$ & $\mathrm{X}$ & & \\
\hline TAN1007-014-03 & & & $\mathrm{X}$ & & $\mathrm{X}$ & \\
\hline TAN1007-014-04 & & & $\mathrm{X}$ & & & \\
\hline TAN1007-014-05 & & & $\mathrm{X}$ & & $\mathrm{X}$ & \\
\hline TAN1007-014-06 & & & $\mathrm{X}$ & & & \\
\hline TAN1007-014-07 & & & $\mathrm{X}$ & & & \\
\hline TAN1007-014-08 & & & $\mathrm{X}$ & & & \\
\hline TAN1007-014-09 & & & $\mathrm{X}$ & & & \\
\hline TAN0205-101-01 & TAN0205-101 & Rapuhia & & & & \\
\hline TAN0205-101-02 & & & $\mathrm{X}$ & $\mathrm{X}$ & $\mathrm{X}$ & \\
\hline TAN0205-101-03 & & & $\mathrm{X}$ & $\mathrm{X}$ & $\mathrm{X}$ & \\
\hline TAN0205-100-03 & TAN0205-100 & Giljanes & $\mathrm{X}$ & $\mathrm{X}$ & $\mathrm{X}$ & \\
\hline TAN1513-040-archive & TAN1513 & Western Havre Trough & $\mathrm{X}$ & & & \\
\hline TAN1513-040 & TAN1513 & & $\mathrm{X}$ & $\mathrm{X}$ & & \\
\hline TAN1513-041 & TAN1513 & & $\mathrm{X}$ & $\mathrm{X}$ & & \\
\hline TAN1513-042 & TAN1513 & & $\mathrm{X}$ & $\mathrm{X}$ & & \\
\hline TAN1513-042-archive & TAN1513 & & $\mathrm{X}$ & & & \\
\hline
\end{tabular}

Table A3.1. List of Samples investigated in this study 


\section{Appendix A2: Representative \\ Petrographic Descriptions}


Figure A2.1 shows photographs and micrographs of whole rock samples from each dredge location. All photomicrographs are in cross-polarised light except for sample TAN0205-10102Basic petrographic descriptions of representative samples are given below:

\section{TAN1007-011-02}

Basalt. $35 \%$ phenocrysts, $25 \%$ vesicles, $40 \%$ groundmass. Phenocryst assemblage consists of $40 \%$ olivine $(3.5-4 \mathrm{~mm}), 50 \%$ pyroxene $(2-4 \mathrm{~mm}), 10 \%$ tabular plagioclase $(0.5-1 \mathrm{~mm})$. Vesicles $(0.5-1 \mathrm{~mm})$ generally singular and sub-rounded. Groundmass consists of dark brown $25 \%$ glass, $40 \%$ acicular plagioclase, $30 \%$ pyroxene $(30 \%)$, and $<5 \% \mathrm{Fe}$-Ti oxides.

\section{TAN1007-011-04}

Basalt. $10 \%$ phenocrysts, $30 \%$ vesicles, $60 \%$ groundmass. Phenocrysts include $15 \%$ olivine (0.5-1 mm) and $85 \%$ pyroxene $(1-1.5 \mathrm{~mm})$. Vesicles generally singular and sub-rounded (0.4$0.8 \mathrm{~mm}$ ) but are also coalesced and reach up to $3 \mathrm{~mm}$. Groundmass consists of $55 \%$ acicular feldspar, $40 \%$ pyroxene, $<5 \% \mathrm{Fe}$-Ti oxides and dark brown glass.

\section{TAN1007-011-06}

Basalt. $20 \%$ phenocrysts, $10 \%$ vesicles, $70 \%$ groundmass. Phenocryst assemblage comprises $20 \%$ olivine $(0.5-1 \mathrm{~mm}), 60 \%$ pyroxene $(0.5-1.5 \mathrm{~mm})$ and $20 \%$ plagioclase $(0.2-1 \mathrm{~mm})$. Groundmass is comprised of $30 \%$ brown glass, $40 \%$ acicular plagioclase, $30 \%$ pyroxene, and $<5 \%$ Fe-Ti oxides. 


\section{$\underline{\text { TAN1007-011-11 }}$}

Basalt. $20 \%$ phenocrysts, $10 \%$ vesicles, $70 \%$ groundmass. Phenocryst assemblage is comprised of $40 \%$ olivine $(2-6 \mathrm{~mm}), 50 \%$ pyroxene $(1-3 \mathrm{~mm})$ and $10 \%$ tabular plagioclase $(0.4-1 \mathrm{~mm})$. Groundmass consists of $25 \%$ dark brown glass, $40 \%$ acicular feldspar, $30 \%$ pyroxene, and $<5$ $\%$ Fe-Ti oxides.

\section{$\underline{\text { TAN1007-012-01 }}$}

Basalt. $15 \%$ phenocrysts, $20 \%$ vesicles, $65 \%$ groundmass. Phenocryst assemblage consists of $15 \%$ olivine $(1-1.5 \mathrm{~mm}), 75 \%$ pyroxene $(1-3 \mathrm{~mm})$, and $10 \%$ plagioclase $(0.5-1 \mathrm{~mm})$. Vesicles consist of $15 \%$ amygdales. Groundmass consists of $40 \%$ acicular plagioclase, $60 \%$ pyroxene, and $<5 \%$ Fe-Ti oxides and dark brown glass.

\section{$\underline{\text { TAN1007-012-03 }}$}

Basalt. 5\% phenocrysts, $15 \%$ vesicles, $80 \%$ groundmass. Phenocryst assemblage includes $15 \%$ olivine $(0.5-1.5 \mathrm{~mm}) 30 \%$ pyroxene $(0.5-1.5 \mathrm{~mm})$ and $55 \%$ plagioclase $(0.5-1 \mathrm{~mm})$. Vesicles contain $10 \%$ amygdales. Groundmass consists of $20 \%$ brown glass, $40 \%$ acicular feldspar, $35 \%$ pyroxene, and $<5 \%$ Fe-Ti oxides.

\section{TAN1007-012-07}

Basalt. 20\% phenocrysts, 25\% vesicles, 55\% groundmass. Phenocryst assemblage is comprised of $20 \%$ olivine $(1-1.5 \mathrm{~mm}) 25 \%$ pyroxene $(1-1.5 \mathrm{~mm}) 55 \%$ plagioclase $(0.5-1 \mathrm{~mm})$. Vesicles consist of $50 \%$ amygdales. Groundmass consists of 25\% light brown glass, $40 \%$ acicular feldspar, $30 \%$ pyroxene, and $<5 \%$ Fe-Ti oxides. 


\section{$\underline{\text { TAN1007-012-08 }}$}

Basalt. 25\% phenocrysts, 30\% vesicles, $45 \%$ groundmass. Phenocryst assemblage consists of $10 \%$ olivine (1-2 mm), 30\% pyroxene (1-2 mm), and $60 \%$ plagioclase $(1-2 \mathrm{~mm})$. Vesicles are comprised of $20 \%$ amygdales. Groundmass consists of $20 \%$ light brown glass, $35 \%$ acicular feldspar, and $40 \%$ pyroxene, and $<5 \%$ Fe-Ti oxides.

\section{$\underline{\text { TAN1007-015-03 }}$}

Basalt. $10 \%$ phenocryst, $40 \%$ vesicles, $40 \%$ groundmass. $35 \%$ olivine $(0.5-1 \mathrm{~mm})$ and $65 \%$ pyroxene $(0.5-1 \mathrm{~mm})$. Groundmass comprises $10 \%$ brown glass, $40 \%$ acicular feldspar, and $60 \%$ pyroxene.

\section{TAN1007-015-04}

Basalt. 20\% phenocryst, $20 \%$ vesicles, $60 \%$ groundmass. Phenocryst assemblage consists of $30 \%$ olivine $(0.5-0.8 \mathrm{~mm}), 70 \%$ pyroxene $(0.5-0.8 \mathrm{~mm})$. Groundmass consists of $50 \%$ acicular feldspar, and $45 \%$ pyroxene, and $<5 \%$ Fe-Ti oxides and dark brown glass.

\section{TAN1007-016-01}

Basalt. 20\% phenocryst, 20\% vesicles, $60 \%$ groundmass. Phenocryst assemblage comprises $60 \%$ olivine $(0.5-1 \mathrm{~mm})$ and $35 \%$ pyroxene $(1-1.5 \mathrm{~mm})$. Groundmass comprises $50 \%$ acicular plagioclase, $40 \%$ pyroxene, and $<5 \%$ Fe-Ti oxides and dark brown glass.

\section{TAN1007-016-06}

Basalt. $10 \%$ phenocrysts, $30 \%$ vesicles, $60 \%$ groundmass. Phenocryst assemblage is comprised of $30 \%$ olivine $(0.6-0.8 \mathrm{~mm}), 70 \%$ pyroxene $(0.6-0.8 \mathrm{~mm})$. Groundmass consists of $\sim 10 \%$ dark brown glass, $50 \%$ acicular plagioclase, $40 \%$ pyroxene, and $<5 \% \mathrm{Fe}$-Ti oxides. 


\section{$\underline{\text { TAN1007-014-03 }}$}

Dacite. $20 \%$ phenocrysts, $15 \%$ vesicles, $65 \%$ groundmass. Phenocryst assemblage comprises $10 \%$ pyroxene $(0.4-1 \mathrm{~mm}), 90 \%$ plagioclase $(0.4-1 \mathrm{~mm})$. Micro-phenocrysts include $\mathrm{Fe}-\mathrm{Ti}$ oxides and apatite. Groundmass consists of $70 \%$ plagioclase, $25 \%$ glass, and 5\% Fe-Ti oxides and apatite.

\section{TAN1007-014-05}

Dacite. $15 \%$ phenocrysts, $15 \%$ vesicles, $70 \%$ groundmass. Phenocryst assemblage includes 95\% plagioclase, and 5\% pyroxene. Micro-phenocrysts include Fe-Ti oxides and apatite. Groundmass consists of $60 \%$ plagioclase, $35 \%$ glass, and $5 \% \mathrm{Fe}-\mathrm{Ti}$ oxides and apatite.

\section{$\underline{\text { TAN0205-101-02 }}$}

Dacite. $40 \%$ phenocrysts, $<5 \%$ vesicles, $55 \%$ groundmass. Phenocryst assemblage consists of $65 \%$ plagioclase $(0.5-2 \mathrm{~mm})$ and $35 \%$ amphibole $(0.1-1.5 \mathrm{~mm})$. Micro-phenocrysts include amphibole, Fe-Ti oxides and apatite. Groundmass consists of $70 \%$ plagioclase, $25 \%$ glass, and $5 \% \mathrm{Fe}-\mathrm{Ti}$ oxides and apatite.

\section{TAN0205-100-03}

Andesite. $65 \%$ phenocrysts, $<5 \%$ vesicles, $30 \%$ groundmass. Phenocryst assemblage consists of $35 \%$ clinopyroxene $(0.5-2.5 \mathrm{~mm})$ and $60 \%$ plagioclase $(0.5-3 \mathrm{~mm})$, and $<5 \%$ amphibole $(<5$ $\mathrm{mm}$ ). Micro-phenocrysts include Fe-Ti oxides and apatite. Groundmass consists of $65 \%$ plagioclase, $30 \%$ glass, and $5 \% \mathrm{Fe}-\mathrm{Ti}$ oxides and apatite. 


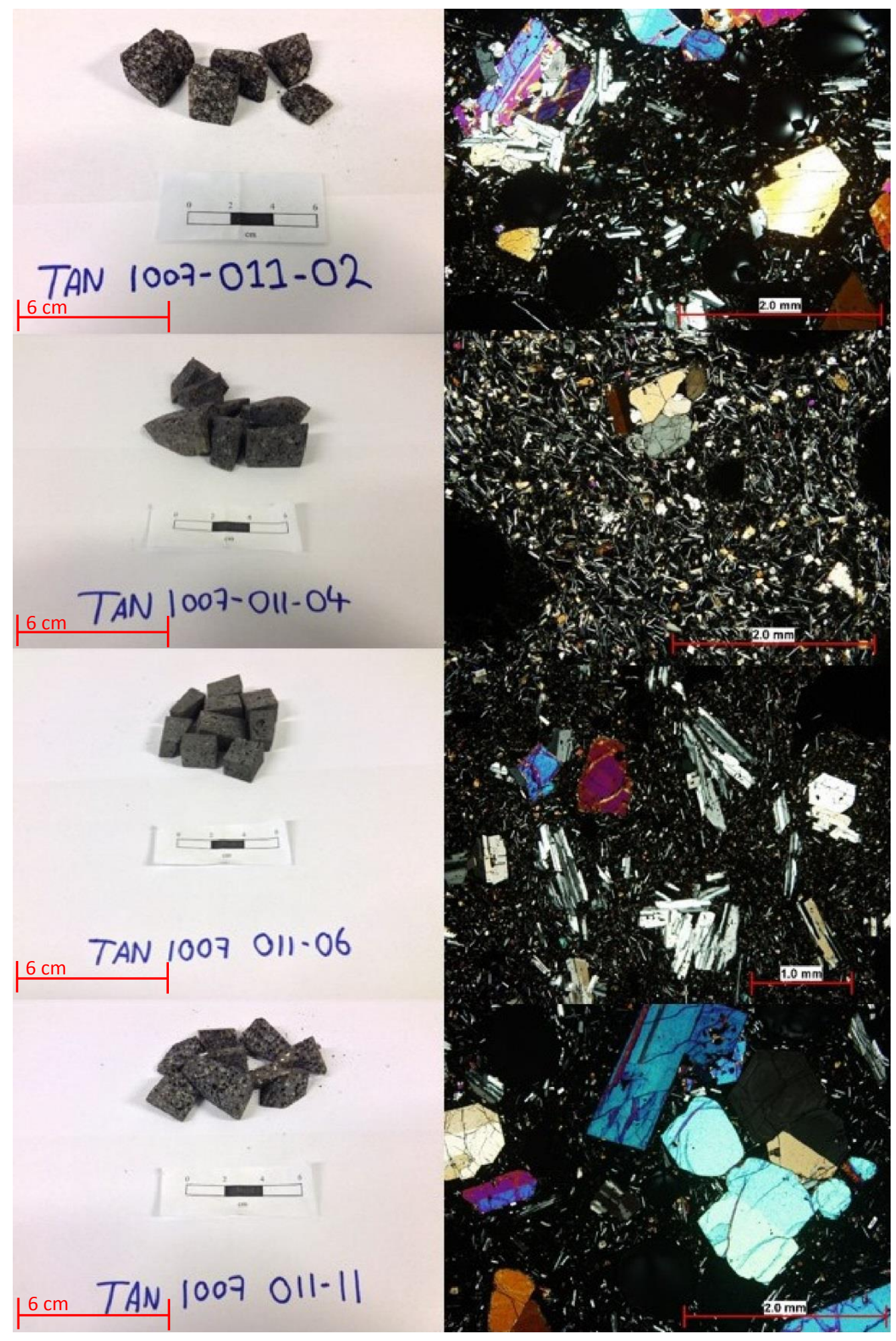

Figure A2.1. Photographs and micrographs of samples from back-arc stratovolcanoes 


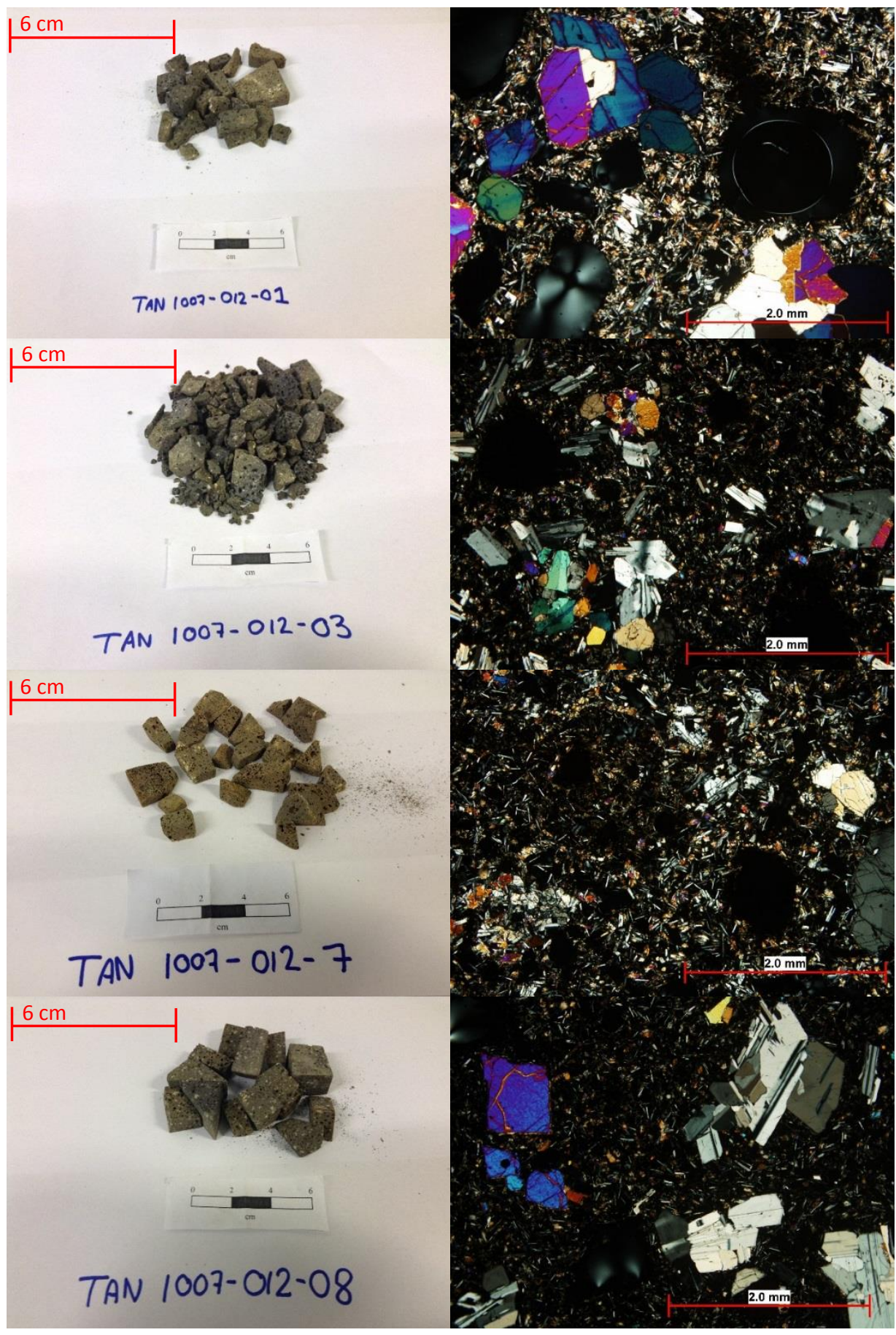

Figure A2.1 cont. 


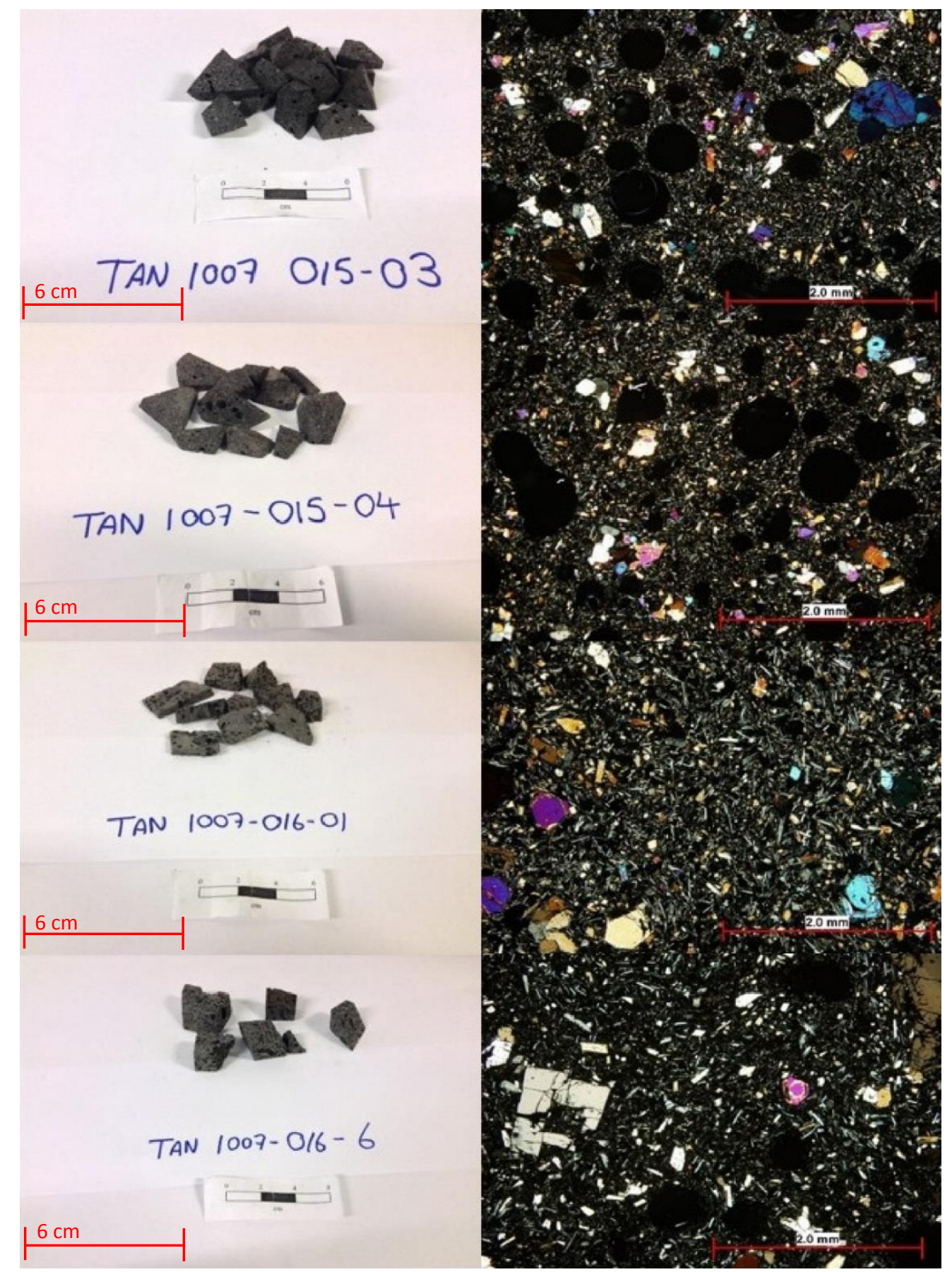

Figure A2.1 cont. 


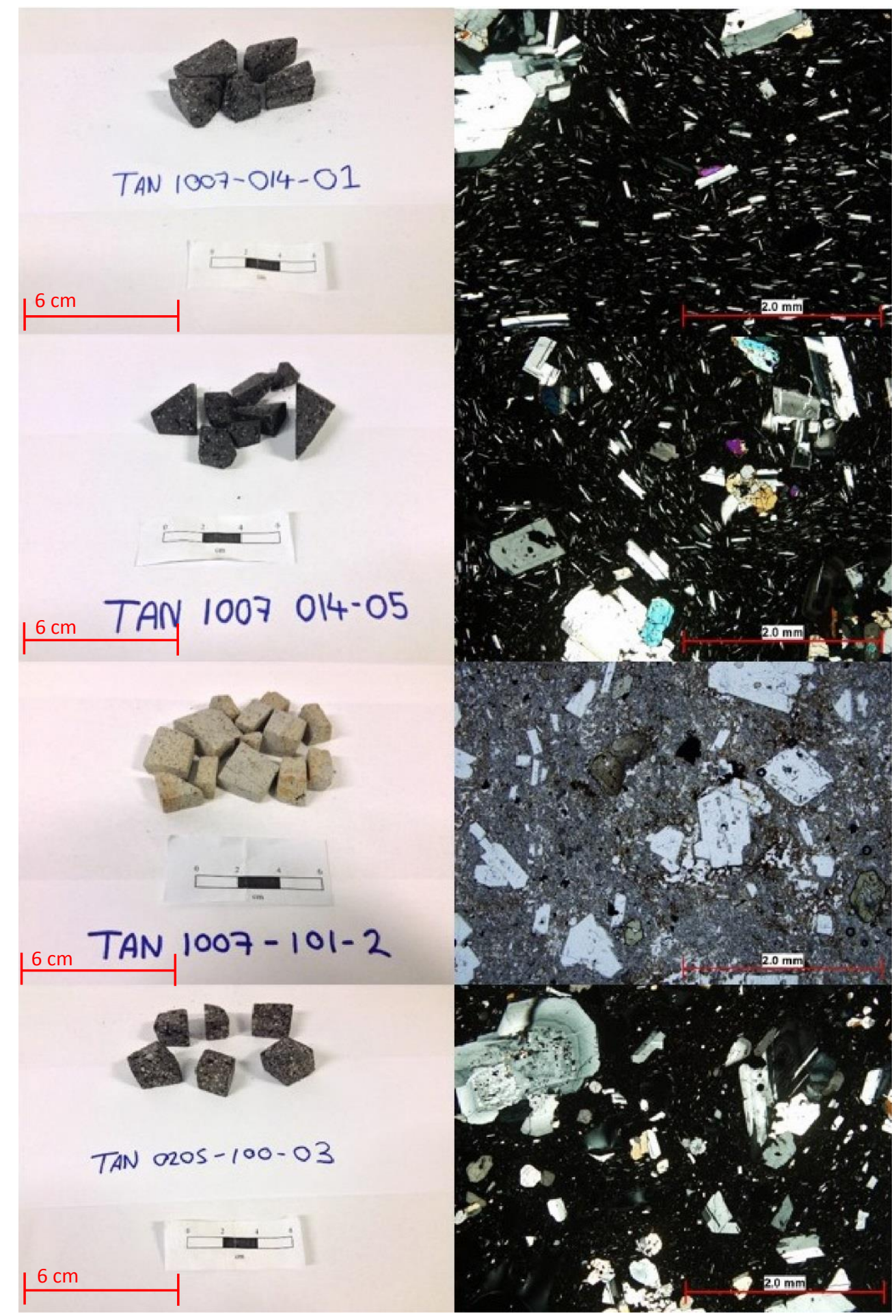

Figure A2.1 cont. 


\section{Appendix A3: Analytical Standards and Uncertainties}




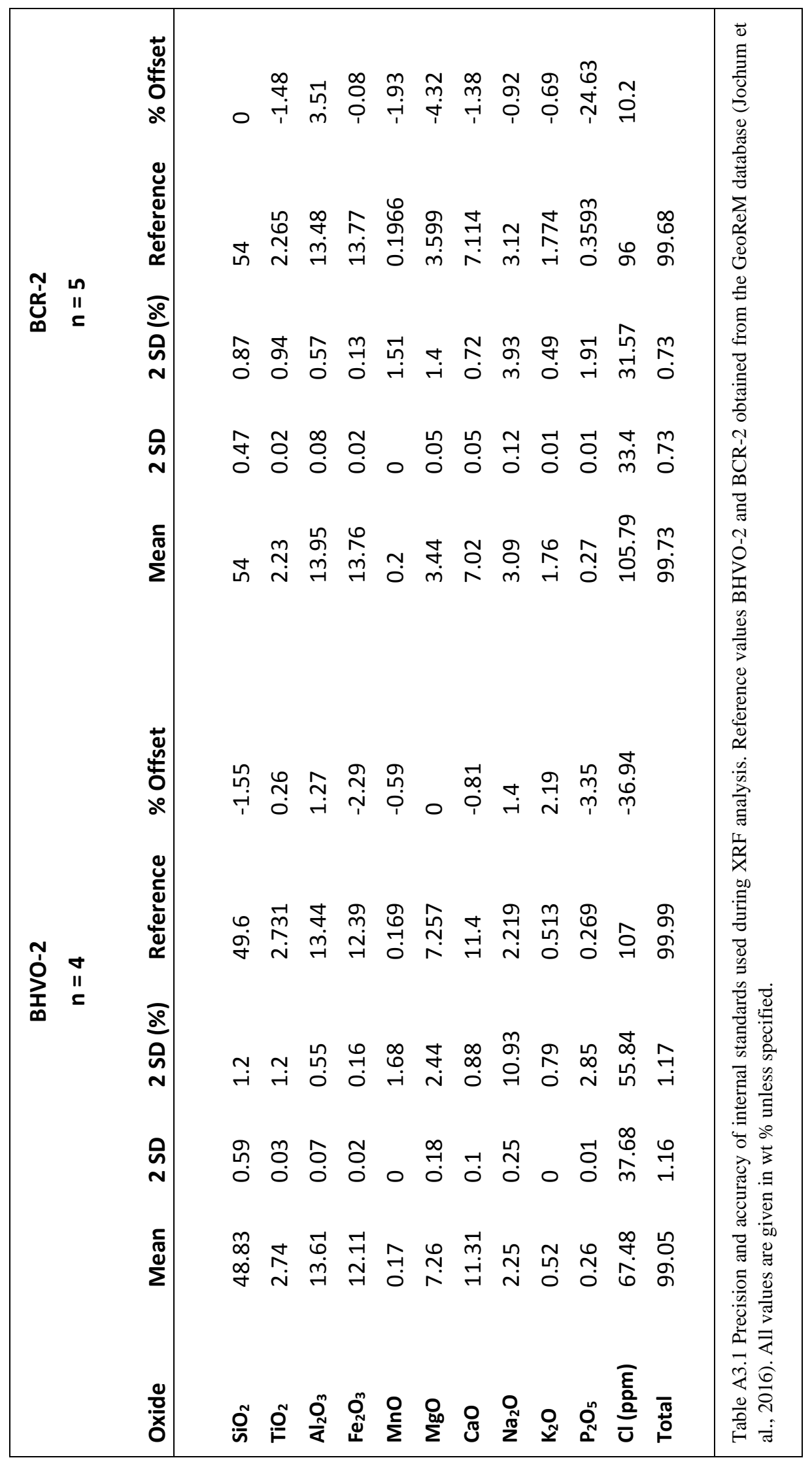




\begin{tabular}{|c|c|c|c|c|}
\hline \multirow[t]{2}{*}{ Element } & \multicolumn{2}{|c|}{ BHVO-2 } & \multicolumn{2}{|c|}{ BCR-2 } \\
\hline & 2008 & 2016 & 2008 & 2016 \\
\hline Li & 4.8 & 4.5 & 9 & 9.13 \\
\hline $\mathrm{Be}$ & 1.0 & 1.08 & & 2.17 \\
\hline MgO (wt \%) & 7.23 & 7.26 & 3.59 & 3.6 \\
\hline $\mathrm{CaO}$ (wt \%) & 11.4 & 11.4 & 7.12 & 7.11 \\
\hline $\mathrm{Al}_{2} \mathrm{O}_{3}$ (wt \%) & 13.5 & 13.44 & 13.5 & 13.48 \\
\hline Sc & 32 & 31.83 & 33 & 33.53 \\
\hline v & 317 & 318.2 & 416 & 417.6 \\
\hline $\mathrm{Cr}$ & 280 & 287.2 & 18 & 15.85 \\
\hline MnO (wt \%) & 0.17 & 0.17 & 0.2 & 0.2 \\
\hline Co & 45 & 44.89 & 37 & 37.33 \\
\hline $\mathrm{Ni}$ & 119 & 119.8 & 18 & 12.57 \\
\hline $\mathrm{Cu}$ & 127 & 129.3 & 21 & 19.66 \\
\hline $\mathrm{Zn}$ & 103 & 103.9 & 127 & 129.5 \\
\hline Ga & 22 & 21.37 & 23 & 22.07 \\
\hline $\mathbf{R b}$ & 9.11 & 9.26 & 46.9 & 46.02 \\
\hline $\mathrm{Sr}$ & 396 & 394.1 & 340 & 337.40 \\
\hline $\mathbf{Y}$ & 26 & 25.91 & 37 & 36.07 \\
\hline $\mathrm{Zr}$ & 172 & 171.2 & 184 & 186.4 \\
\hline $\mathrm{Nb}$ & 18.1 & 18.1 & 12.6 & 12.44 \\
\hline $\mathrm{Cd}$ & 0.06 & 0.15 & & 0.69 \\
\hline Cs & 0.1 & 0.1 & 1.1 & 1.16 \\
\hline $\mathrm{Ba}$ & 131 & 130.9 & 677 & 683.9 \\
\hline La & 15.2 & 15.2 & 24.9 & 25.08 \\
\hline $\mathrm{Ce}$ & 37.5 & 37.53 & 52.9 & 53.12 \\
\hline $\mathrm{Pr}$ & 5.35 & 5.34 & 6.7 & 6.83 \\
\hline Nd & 24.5 & 24.27 & 29.7 & 28.26 \\
\hline Sm & 6.07 & 6.02 & 6.58 & 6.55 \\
\hline Eu & 2.07 & 2.04 & 1.96 & 1.99 \\
\hline Gd & 6.24 & 6.21 & 6.75 & 6.81 \\
\hline Tb & 0.92 & 0.94 & 1.07 & 1.08 \\
\hline Dy & 5.31 & 5.28 & 6.41 & 6.42 \\
\hline Ho & 0.98 & 0.99 & 1.28 & 1.31 \\
\hline $\mathrm{Er}$ & 2.54 & 2.51 & 3.66 & 3.67 \\
\hline $\mathrm{Tm}$ & 0.33 & 0.33 & 0.54 & 0.53 \\
\hline $\mathrm{Yb}$ & 2.0 & 1.99 & 3.38 & 3.39 \\
\hline Lu & 0.27 & 0.28 & 0.5 & 0.5 \\
\hline $\mathrm{Hf}$ & 4.36 & 4.47 & 4.9 & 4.97 \\
\hline Ta & 1.14 & 1.15 & 0.74 & 0.79 \\
\hline w & 0.21 & 0.25 & & 0.47 \\
\hline $\mathbf{P b}$ & 1.6 & 1.65 & 11 & 10.59 \\
\hline Th & 1.22 & 1.22 & 5.7 & 5.83 \\
\hline U & 0.4 & 0.41 & 1.69 & 1.68 \\
\hline
\end{tabular}

Table A3.2. List of preferred values for element abundances of whole rock powdered standards BHVO-2 and BCR2 used for trace element solution ICP-MS analysis. Values obtained from the GeoREM database (Jochum and Nohl, 2008; Jochum et al., 2016). All values are given in ppm unless specified. 


\begin{tabular}{|c|c|c|c|c|c|}
\hline \multicolumn{6}{|c|}{ BCR-2 Whole Rock Powder } \\
\hline Element & Mean & 2 SD & 2 SD (\%) & Reference & $\%$ Offset \\
\hline Li & 9.67 & 1.52 & 15.71 & 9.13 & -5.62 \\
\hline $\mathrm{Be}$ & 2.33 & 0.45 & 19.14 & & \\
\hline MgO (wt \%) & 3.64 & 0.30 & 8.16 & 3.6 & -1.25 \\
\hline $\mathrm{Al}_{2} \mathrm{O}_{3}$ (wt \%) & 13.52 & 0.68 & 5.00 & 13.48 & -0.29 \\
\hline Sc & 33.61 & 1.30 & 3.88 & 33.53 & -0.25 \\
\hline $\mathbf{v}$ & 422.52 & 12.57 & 2.97 & 417.6 & -1.16 \\
\hline $\mathrm{Cr}$ & 22.48 & 25.86 & 115.02 & 15.85 & -29.49 \\
\hline MnO (wt \%) & 0.20 & 0.01 & 4.22 & 0.2 & -1.35 \\
\hline Co & 37.85 & 1.08 & 2.86 & 37.33 & -1.37 \\
\hline $\mathrm{Ni}$ & 12.40 & 2.41 & 19.39 & 12.57 & 1.33 \\
\hline $\mathrm{Cu}$ & 17.57 & 0.67 & 3.81 & 19.66 & 11.90 \\
\hline $\mathrm{Zn}$ & 135.25 & 15.79 & 11.68 & 129.5 & -4.25 \\
\hline Ga & 22.20 & 0.71 & 3.21 & 22.07 & -0.57 \\
\hline $\mathbf{R b}$ & 48.15 & 1.79 & 3.71 & 46.02 & -4.43 \\
\hline $\mathrm{Sr}$ & 342.69 & 11.60 & 3.39 & 337.4 & -1.54 \\
\hline$Y$ & 36.08 & 1.13 & 3.13 & 36.07 & -0.03 \\
\hline $\mathrm{Zr}$ & 188.53 & 8.08 & 4.29 & 186.4 & -1.13 \\
\hline $\mathrm{Nb}$ & 12.48 & 0.51 & 4.08 & 12.44 & -0.29 \\
\hline $\mathrm{Cd}$ & 0.52 & 0.21 & 39.91 & 0.69 & 32.01 \\
\hline Cs & 1.09 & 0.17 & 15.81 & 1.16 & 6.54 \\
\hline $\mathrm{Ba}$ & 694.03 & 25.98 & 3.74 & 683.9 & -1.46 \\
\hline La & 25.38 & 0.75 & 2.97 & 25.08 & -1.18 \\
\hline $\mathrm{Ce}$ & 53.95 & 1.73 & 3.20 & 53.12 & -1.55 \\
\hline $\mathrm{Pr}$ & 6.93 & 0.25 & 3.64 & 6.83 & -1.42 \\
\hline Nd & 28.79 & 0.89 & 3.08 & 28.26 & -1.84 \\
\hline Sm & 6.59 & 0.38 & 5.75 & 6.55 & -0.69 \\
\hline Eu & 2.04 & 0.08 & 3.69 & 1.99 & -2.40 \\
\hline Gd & 6.95 & 0.29 & 4.15 & 6.81 & -2.00 \\
\hline Tb & 1.07 & 0.04 & 3.99 & 1.08 & 0.34 \\
\hline Dy & 6.47 & 0.28 & 4.28 & 6.42 & -0.73 \\
\hline Ho & 1.32 & 0.06 & 4.59 & 1.31 & -0.20 \\
\hline $\mathrm{Er}$ & 3.67 & 0.13 & 3.66 & 3.67 & 0.11 \\
\hline $\mathrm{Tm}$ & 0.53 & 0.03 & 6.61 & 0.53 & 1.58 \\
\hline $\mathrm{Yb}$ & 3.41 & 0.14 & 4.22 & 3.39 & -0.42 \\
\hline Lu & 0.50 & 0.03 & 6.54 & 0.5 & 0.72 \\
\hline $\mathrm{Hf}$ & 5.01 & 0.19 & 3.75 & 4.97 & -0.69 \\
\hline $\mathrm{Ta}$ & 0.79 & 0.05 & 6.76 & 0.79 & -1.14 \\
\hline$w$ & 0.49 & 0.15 & 31.35 & 0.47 & -5.81 \\
\hline $\mathrm{Pb}$ & 11.09 & 3.09 & 27.88 & 10.59 & -4.53 \\
\hline Th & 5.88 & 0.36 & 6.19 & 5.83 & -0.85 \\
\hline u & 1.68 & 0.10 & 6.19 & 1.68 & 0.43 \\
\hline
\end{tabular}

Table A3.3. Summary of trace element data obtained for USGS international standard BCR-2. All values are normalised to $\mathrm{CaO}$, and are given in ppm unless stated otherwise. 


\begin{tabular}{|c|c|c|c|c|c|c|}
\hline \multirow{2}{*}{$\begin{array}{l}\text { Sample } \\
\text { Element }\end{array}$} & \multicolumn{3}{|c|}{ TAN1007-011-06 } & \multicolumn{3}{|c|}{ TAN1007-011-03 } \\
\hline & run 1 & run 2 & $\%$ Offset & run 1 & run 2 & $\%$ Offset \\
\hline $\mathbf{L i}$ & 5.15 & 5.17 & 0.33 & 5.41 & 5.43 & 0.48 \\
\hline $\mathrm{Be}$ & 0.54 & 0.83 & 52.36 & 0.69 & & \\
\hline MgO (wt \%) & 6.14 & 5.50 & -10.53 & 7.08 & 7.20 & 1.58 \\
\hline $\mathrm{Al}_{2} \mathrm{O}_{3}$ (wt \%) & 18.74 & 17.98 & -4.09 & 16.89 & 16.95 & 0.36 \\
\hline Sc & 32.90 & 33.28 & 1.15 & 34.87 & 35.22 & 0.98 \\
\hline v & 323.44 & 326.84 & 1.05 & 308.04 & 303.24 & -1.56 \\
\hline $\mathrm{Cr}$ & 67.72 & 71.22 & 5.17 & 216.56 & 204.07 & -5.77 \\
\hline MnO (wt \%) & 0.16 & 0.17 & 1.13 & 0.17 & 0.17 & -0.47 \\
\hline Co & 29.70 & 31.02 & 4.43 & 35.58 & 34.38 & -3.37 \\
\hline $\mathrm{Ni}$ & 45.03 & 43.29 & -3.86 & 89.43 & 88.17 & -1.40 \\
\hline Zn & 69.53 & 69.67 & 0.20 & 72.60 & 76.41 & 5.24 \\
\hline Ga & 17.72 & 17.17 & -3.08 & 16.75 & 16.48 & -1.63 \\
\hline $\mathbf{R b}$ & 15.43 & 15.24 & -1.25 & 14.11 & 14.15 & 0.27 \\
\hline $\mathrm{Sr}$ & 461.08 & 453.88 & -1.56 & 432.22 & 427.94 & -0.99 \\
\hline$Y$ & 23.27 & 23.20 & -0.32 & 21.75 & 21.47 & -1.25 \\
\hline $\mathrm{Zr}$ & 83.85 & 82.46 & -1.66 & 75.91 & 78.18 & 2.99 \\
\hline $\mathrm{Nb}$ & 6.57 & 6.50 & -1.04 & 5.88 & 6.03 & 2.58 \\
\hline Cs & 0.28 & 0.28 & 1.35 & 0.24 & 0.24 & 2.46 \\
\hline $\mathrm{Ba}$ & 253.83 & 254.64 & 0.32 & 230.93 & 231.92 & 0.43 \\
\hline La & 13.28 & 13.16 & -0.92 & 11.93 & 12.04 & 0.89 \\
\hline $\mathrm{Ce}$ & 27.74 & 27.49 & -0.88 & 25.78 & 25.60 & -0.71 \\
\hline $\mathrm{Pr}$ & 3.80 & 3.79 & -0.31 & 3.55 & 3.51 & -1.10 \\
\hline $\mathrm{Nd}$ & 16.72 & 16.48 & -1.42 & 15.36 & 15.19 & -1.08 \\
\hline Sm & 4.09 & 3.89 & -4.86 & 3.72 & 3.70 & -0.57 \\
\hline Eu & 1.36 & 1.29 & -5.44 & 1.24 & 1.25 & 0.74 \\
\hline Gd & 4.17 & 4.00 & -3.90 & 4.00 & 3.89 & -2.88 \\
\hline $\mathrm{Tb}$ & 0.65 & 0.67 & 3.40 & 0.63 & 0.62 & -1.87 \\
\hline Dy & 4.11 & 4.04 & -1.81 & 3.70 & 3.73 & 0.81 \\
\hline Ho & 0.88 & 0.85 & -4.22 & 0.82 & 0.79 & -2.96 \\
\hline $\mathrm{Er}$ & 2.36 & 2.42 & 2.41 & 2.18 & 2.30 & 5.55 \\
\hline $\mathrm{Tm}$ & 0.35 & 0.36 & 0.87 & 0.34 & 0.33 & -1.60 \\
\hline $\mathrm{Yb}$ & 2.29 & 2.24 & -2.08 & 2.12 & 2.10 & -0.72 \\
\hline Lu & 0.34 & 0.35 & 2.51 & 0.33 & 0.30 & -8.68 \\
\hline Hf & 2.16 & 2.19 & 1.44 & 2.01 & 2.12 & 5.29 \\
\hline $\mathrm{Ta}$ & 0.39 & 0.39 & 1.25 & 0.37 & 0.37 & 0.92 \\
\hline$w$ & 0.18 & 0.14 & -20.18 & 0.17 & 0.24 & 37.42 \\
\hline $\mathrm{Pb}$ & 1.79 & 1.78 & -0.81 & 2.27 & 2.19 & -3.32 \\
\hline Th & 1.81 & 1.80 & -0.54 & 1.67 & 1.77 & 6.53 \\
\hline U & 0.53 & 0.54 & 0.15 & 0.52 & 0.50 & -3.51 \\
\hline
\end{tabular}

Table A3.4. Summary of trace element data obtained for duplicate dissolutions of samples TAN1007-011-06 and TAN1007-011-03, providing estimates of the reproducibility of ICP-MS analyses. All values are normalised to $\mathrm{CaO}$, and are given in ppm unless stated otherwise. 


\begin{tabular}{|c|c|c|c|c|c|c|}
\hline \multirow{2}{*}{$\begin{array}{l}\text { Sample } \\
\text { Element }\end{array}$} & \multirow[b]{2}{*}{ run 1} & \multirow[b]{2}{*}{ run 2} & \multicolumn{2}{|c|}{ TAN1007-011-11 } & \multirow[b]{2}{*}{$2 S D$} & \multirow[b]{2}{*}{2 SD (\%) } \\
\hline & & & run 3 & mean & & \\
\hline Li & 4.55 & 4.19 & 4.81 & 4.52 & 0.62 & 13.70 \\
\hline $\mathrm{Be}$ & 0.43 & 0.34 & & & & \\
\hline MgO (wt \%) & 12.65 & 12.26 & 12.61 & 12.51 & 0.43 & 3.41 \\
\hline $\mathrm{Al}_{2} \mathrm{O}_{3}$ (wt \%) & 13.01 & 12.46 & 13.22 & 12.89 & 0.78 & 6.09 \\
\hline Sc & 41.81 & 40.71 & 42.20 & 41.57 & 1.54 & 3.71 \\
\hline v & 264.15 & 253.52 & 255.43 & 257.70 & 11.34 & 4.40 \\
\hline $\mathrm{Cr}$ & 771.18 & 776.20 & 757.23 & 768.20 & 19.67 & 2.56 \\
\hline MnO (wt \%) & 0.17 & 0.17 & 0.18 & 0.17 & 0.01 & 4.47 \\
\hline Co & 50.55 & 48.14 & 48.20 & 48.96 & 2.75 & 5.61 \\
\hline $\mathrm{Ni}$ & 254.87 & 243.44 & 250.16 & 249.49 & 11.48 & 4.60 \\
\hline $\mathrm{Zn}$ & 69.24 & 63.41 & 65.80 & 66.15 & 5.87 & 8.87 \\
\hline Ga & 12.93 & 12.23 & 12.93 & 12.69 & 0.81 & 6.41 \\
\hline $\mathbf{R b}$ & 9.61 & 8.96 & 9.45 & 9.34 & 0.67 & 7.22 \\
\hline $\mathrm{Sr}$ & 330.77 & 312.16 & 328.48 & 323.80 & 20.30 & 6.27 \\
\hline $\mathbf{Y}$ & 17.63 & 16.75 & 17.64 & 17.34 & 1.03 & 5.93 \\
\hline $\mathrm{Zr}$ & 55.78 & 53.64 & 61.13 & 56.85 & 7.71 & 13.57 \\
\hline $\mathrm{Nb}$ & 4.28 & 4.13 & 4.52 & 4.31 & 0.40 & 9.16 \\
\hline Cs & 0.17 & 0.14 & 0.16 & 0.16 & 0.03 & 21.64 \\
\hline $\mathrm{Ba}$ & 165.36 & 159.13 & 165.92 & 163.47 & 7.54 & 4.61 \\
\hline La & 9.03 & 8.59 & 9.19 & 8.93 & 0.62 & 6.99 \\
\hline $\mathrm{Ce}$ & 19.16 & 18.21 & 19.26 & 18.88 & 1.16 & 6.14 \\
\hline $\mathrm{Pr}$ & 2.65 & 2.50 & 2.65 & 2.60 & 0.17 & 6.57 \\
\hline $\mathbf{N d}$ & 11.87 & 11.20 & 11.66 & 11.58 & 0.68 & 5.89 \\
\hline Sm & 2.87 & 2.76 & 2.88 & 2.84 & 0.13 & 4.72 \\
\hline Eu & 0.95 & 0.94 & 1.00 & 0.97 & 0.06 & 6.07 \\
\hline Gd & 3.20 & 2.90 & 3.21 & 3.10 & 0.35 & 11.40 \\
\hline Tb & 0.51 & 0.46 & 0.48 & 0.48 & 0.05 & 10.83 \\
\hline Dy & 3.05 & 2.86 & 3.05 & 2.99 & 0.22 & 7.26 \\
\hline Ho & 0.65 & 0.63 & 0.62 & 0.63 & 0.04 & 6.08 \\
\hline $\mathrm{Er}$ & 1.78 & 1.69 & 1.79 & 1.75 & 0.11 & 6.47 \\
\hline $\mathrm{Tm}$ & 0.27 & 0.25 & 0.26 & 0.26 & 0.02 & 8.13 \\
\hline $\mathrm{Yb}$ & 1.68 & 1.65 & 1.69 & 1.67 & 0.05 & 2.96 \\
\hline Lu & 0.25 & 0.25 & 0.26 & 0.26 & 0.01 & 3.83 \\
\hline Hf & 1.54 & 1.49 & 1.64 & 1.56 & 0.16 & 10.07 \\
\hline $\mathrm{Ta}$ & 0.27 & 0.25 & 0.28 & 0.27 & 0.03 & 10.39 \\
\hline w & 0.15 & 0.14 & 0.19 & 0.16 & 0.06 & 34.39 \\
\hline $\mathrm{Pb}$ & 1.83 & 1.67 & 1.74 & 1.75 & 0.16 & 9.07 \\
\hline Th & 1.25 & 1.17 & 1.27 & 1.23 & 0.10 & 7.92 \\
\hline $\mathbf{U}$ & 0.40 & 0.37 & 0.37 & 0.38 & 0.03 & 8.62 \\
\hline
\end{tabular}

Table A3.5. Summary of trace element data obtained for duplicate dissolutions of samples TAN1007-011-11, providing estimates of the reproducibility of ICP-MS analyses. All values are normalised to $\mathrm{CaO}$, and are given in ppm unless stated otherwise. 


\begin{tabular}{|c|c|c|}
\hline Mineral & Matrix-Matched Standards & Synthetic Oxides \\
\hline Olivine & Springwater Olivine (Si, Mg, Fe) & $\begin{array}{l}\mathrm{Al}_{2} \mathrm{O}_{3}, \mathrm{TiO}_{2}, \mathrm{MnO}, \mathrm{CaO} \\
\text { (Wollastonite), } \mathrm{Cr}_{2} \mathrm{O}_{3}, \mathrm{NiO}\end{array}$ \\
\hline Clinopyroxene & Kakanui Augite (Si, Al, Mg, Na, Ca, Fe, Ti) & $\begin{array}{l}\mathrm{TiO}_{2}, \mathrm{MnO}, \mathrm{K}_{2} \mathrm{O} \text { (Orthoclase } \\
\text { Or- } 1 \mathrm{~A}), \mathrm{Cr}_{2} \mathrm{O}_{3}, \mathrm{NiO}\end{array}$ \\
\hline Plagioclase & Plagiocalse (Si, Al, Mg, Na, Ca) & $\begin{array}{l}\mathrm{TiO}_{2}, \mathrm{Fe}_{2} \mathrm{O}_{3}, \mathrm{MnO}, \mathrm{MgO}, \mathrm{K}_{2} \mathrm{O} \\
\text { (Orthoclase Or-1A) }\end{array}$ \\
\hline Ilmenite & Ilmenite (Ti, Fe) & $\mathrm{Al}_{2} \mathrm{O}_{3}, \mathrm{MnO}, \mathrm{MgO}, \mathrm{Cr}_{2} \mathrm{O}_{3}$ \\
\hline Magnetite & Magnetite (Ti, Fe) & $\mathrm{Al}_{2} \mathrm{O}_{3}, \mathrm{MnO}, \mathrm{MgO}, \mathrm{Cr}_{2} \mathrm{O}_{3}$ \\
\hline Cr-Spinel & $\begin{array}{l}\text { Magnetite (Ti, Fe) } \\
\text { Springwater Olivine (Si) }\end{array}$ & $\mathrm{Al}_{2} \mathrm{O}_{3}, \mathrm{MnO}, \mathrm{MgO}, \mathrm{Cr}_{2} \mathrm{O}_{3}$ \\
\hline Apatite & Beeson Apatite (Si, Ca, P, F) & $\begin{array}{l}\mathrm{K}_{2} \mathrm{O} \text { (Orthoclase Or-1A), } \mathrm{Cl} \\
\text { (Scaptolite) }\end{array}$ \\
\hline Amphibole & $\begin{array}{l}\text { Engels Amphibole ( } \mathrm{Si}, \mathrm{Al}, \mathrm{Mg}, \mathrm{Na}, \mathrm{Ca}, \mathrm{Fe}) \\
\text { Hornblende ( } \mathrm{Si}, \mathrm{Al}, \mathrm{Mg}, \mathrm{Na}, \mathrm{Ca}, \mathrm{Fe})\end{array}$ & $\begin{array}{l}\mathrm{TiO}_{2}, \mathrm{~K}_{2} \mathrm{O} \text { (Orthoclase Or-1A), } \\
\mathrm{Cl} \text { (Scaptolite) }\end{array}$ \\
\hline
\end{tabular}

Table A3.6. List of all minerals and standards used during EPMA analysis.

\begin{tabular}{|c|c|c|c|c|c|c|c|}
\hline \multicolumn{8}{|c|}{$\begin{array}{l}\text { Springwater Olivine } \\
n=77\end{array}$} \\
\hline & Mean & Min & Max & $2 S D$ & 2 SD (\%) & Reference & $\%$ Offset \\
\hline $\mathrm{SiO}_{2}$ & 40.14 & 39.01 & 40.60 & 0.68 & 1.70 & 38.95 & 3.07 \\
\hline $\mathrm{Al}_{2} \mathrm{O}_{3}$ & 0.00 & 0.00 & 0.03 & 0.01 & 435.70 & & \\
\hline $\mathrm{TiO}_{2}$ & 0.00 & 0.00 & 0.02 & 0.01 & 359.89 & & \\
\hline $\mathrm{FeO}$ & 17.11 & 16.20 & 17.47 & 0.46 & 2.66 & 16.62 & 2.97 \\
\hline MnO & 0.31 & 0.26 & 0.37 & 0.04 & 14.25 & 0.3 & 4.99 \\
\hline MgO & 45.19 & 43.20 & 45.95 & 1.12 & 2.48 & 43.58 & 3.70 \\
\hline $\mathrm{CaO}$ & 0.00 & 0.00 & 0.01 & 0.00 & 606.41 & & \\
\hline $\mathrm{Na}_{2} \mathrm{O}$ & 0.00 & 0.00 & 0.02 & 0.01 & 348.41 & & \\
\hline $\mathrm{K}_{2} \mathrm{O}$ & 0.00 & 0.00 & 0.01 & 0.01 & 342.45 & & \\
\hline $\mathrm{Cr}_{2} \mathrm{O}_{3}$ & 0.02 & 0.00 & 0.06 & 0.03 & 162.62 & 0.02 & 2.53 \\
\hline $\mathrm{NiO}$ & 0.00 & 0.00 & 0.03 & 0.01 & 356.69 & & \\
\hline Total & 102.80 & 98.86 & 104.25 & 2.14 & 2.08 & 99.47 & 3.35 \\
\hline
\end{tabular}

Table A3.7a. Summary of EPMA data acquired for international mineral standard Springwater Olivine, showing the precision and accuracy of olivine major element analysis. Reference values are from Jarosewich et al. (1980). All values are givne in wt $\%$ unless specified otherwise. 


\begin{tabular}{|c|c|c|c|c|c|c|c|}
\hline \multicolumn{8}{|c|}{$\begin{array}{c}\text { Kakanui Augite } \\
\qquad n=54\end{array}$} \\
\hline & Mean & Min & Max & 2 SD & 2 SD (\%) & Reference & $\%$ Offset \\
\hline $\mathrm{SiO}_{2}$ & 51.24 & 50.67 & 51.73 & 0.40 & 0.79 & 50.73 & 1.00 \\
\hline $\mathrm{Al}_{2} \mathrm{O}_{3}$ & 8.80 & 8.58 & 8.93 & 0.13 & 1.44 & 8.73 & 0.81 \\
\hline $\mathrm{TiO}_{2}$ & 0.55 & 0.52 & 0.60 & 0.03 & 6.33 & 0.74 & -26.09 \\
\hline $\mathrm{FeO}$ & 6.46 & 6.31 & 6.58 & 0.12 & 1.87 & 6.34 & 1.90 \\
\hline MnO & 0.14 & 0.10 & 0.18 & 0.04 & 28.72 & 0.13 & 8.83 \\
\hline MgO & 16.90 & 16.66 & 17.09 & 0.21 & 1.26 & 16.65 & 1.48 \\
\hline $\mathrm{CaO}$ & 14.16 & 13.68 & 14.57 & 0.33 & 2.34 & 15.82 & -10.50 \\
\hline $\mathrm{Na}_{2} \mathrm{O}$ & 1.17 & 1.10 & 1.27 & 0.07 & 5.83 & 1.27 & -7.95 \\
\hline $\mathrm{K}_{2} \mathrm{O}$ & 0.01 & 0.00 & 0.01 & 0.01 & 149.39 & & \\
\hline $\mathrm{Cr}_{2} \mathrm{O}_{3}$ & 0.16 & 0.11 & 0.20 & 0.04 & 27.61 & 0.15 & 4.43 \\
\hline $\mathrm{NiO}$ & 0.02 & 0.00 & 0.07 & 0.04 & 160.90 & & \\
\hline Total & 99.60 & 98.61 & 100.23 & 0.74 & 0.74 & 100.56 & -0.96 \\
\hline
\end{tabular}

Table A3.7b. Summary of EPMA data acquired for international mineral standard Kakanui Augite, showing the precision and accuracy of clinopyroxene major element analysis. Reference values are from Jarosewich et al. (1980) and Klügel et al. (2005).

\begin{tabular}{|c|c|c|c|c|c|c|c|}
\hline \multicolumn{8}{|c|}{$\begin{array}{l}\text { Plagioclase NMNH } 115900 \\
\qquad n=113\end{array}$} \\
\hline & Mean & Min & Max & 2 SD & 2 SD (\%) & Reference & $\%$ Offset \\
\hline $\mathrm{SiO}_{2}$ & 50.67 & 49.00 & 51.74 & 1.56 & 3.02 & 51.25 & -1.14 \\
\hline $\mathrm{Al}_{2} \mathrm{O}_{3}$ & 30.61 & 29.60 & 31.23 & 0.90 & 2.89 & 30.91 & -0.98 \\
\hline $\mathrm{TiO}_{2}$ & 0.02 & 0.00 & 0.06 & 0.03 & 46.24 & 0.05 & -53.59 \\
\hline $\mathrm{FeO}$ & 0.45 & 0.38 & 0.53 & 0.06 & 10.81 & 0.46 & -3.02 \\
\hline MnO & 0.01 & 0.00 & 0.04 & 0.02 & 50.62 & 0.01 & -22.74 \\
\hline MgO & 0.05 & 0.00 & 0.16 & 0.13 & 82.72 & 0.14 & -64.84 \\
\hline $\mathrm{CaO}$ & 13.62 & 13.07 & 13.89 & 0.31 & 2.23 & 13.64 & -0.11 \\
\hline $\mathrm{Na}_{2} \mathrm{O}$ & 3.44 & 3.16 & 3.64 & 0.19 & 5.34 & 3.45 & -0.17 \\
\hline $\mathrm{K}_{2} \mathrm{O}$ & 0.12 & 0.09 & 0.16 & 0.02 & 13.66 & 0.18 & -32.21 \\
\hline Total & 99.00 & 96.11 & 100.66 & 2.69 & 2.67 & 99.73 & -0.74 \\
\hline
\end{tabular}

Table A3.7c. Summary of EPMA data acquired for international standard Plagioclase NMNH 115900, showing the precision and accurary of plagioclase major element analysis. Reference values are from Jarosewich et al. (1980). 


\begin{tabular}{|c|c|c|c|c|c|c|c|}
\hline \multicolumn{8}{|c|}{$\begin{array}{c}\text { Magnetite } \\
n=14\end{array}$} \\
\hline & Mean & Min & Max & 2 SD & 2 SD (\%) & Reference & $\%$ Offset \\
\hline $\mathrm{TiO}_{2}$ & 0.07 & 0.05 & 0.09 & 0.02 & 0.34 & 0.16 & -56.88 \\
\hline FeO & 90.69 & 88.62 & 92.26 & 1.90 & 0.02 & 90.94 & -0.28 \\
\hline MnO & 0.01 & 0.00 & 0.01 & 0.01 & 0.61 & 0.01 & 0.00 \\
\hline MgO & 0.05 & 0.04 & 0.07 & 0.02 & 0.41 & 0.05 & 0.00 \\
\hline $\mathrm{Cr}_{2} \mathrm{O}_{3}$ & 0.25 & 0.18 & 0.29 & 0.07 & 0.29 & 0.25 & 0.00 \\
\hline Total & 91.12 & 89.10 & 92.72 & 1.89 & 0.02 & 91.40 & -0.31 \\
\hline
\end{tabular}

Table A3.7d. Summary of EPMA data acquired for international standard Magnetite NMNH 115900, showing the precision and accuracy of magnetite major element analyses. Reference values are from Jarosewich et al. (1980).

\begin{tabular}{|c|c|c|c|c|c|c|c|}
\hline \multicolumn{8}{|c|}{$\begin{array}{c}\text { Ilmenite } \\
n=14\end{array}$} \\
\hline & Mean & Max & Min & 2 SD & 2 SD (\%) & Reference & $\%$ Offset \\
\hline $\mathrm{TiO}_{2}$ & 45.26 & 44.59 & 45.74 & 0.74 & 0.02 & 45.70 & -0.97 \\
\hline $\mathrm{FeO}$ & 45.46 & 44.18 & 46.48 & 1.41 & 0.03 & 46.54 & -2.32 \\
\hline MnO & 4.61 & 4.07 & 4.87 & 0.44 & 0.10 & 4.77 & -3.39 \\
\hline MgO & 0.30 & 0.28 & 0.31 & 0.03 & 0.09 & 0.31 & -4.73 \\
\hline $\mathrm{Cr}_{2} \mathrm{O}_{3}$ & 0.02 & 0.00 & 0.04 & 0.02 & 1.19 & & \\
\hline Total & 95.66 & 94.40 & 97.01 & 1.58 & 0.02 & 98.24 & -2.63 \\
\hline
\end{tabular}

Table A3.7e. Summary of EPMA data acquired for international standard Ilmenite NMNH 115900, showing the precision and accuracy of ilmenite major element analyses. Reference values are from Jarosewich et al. (1980).

\begin{tabular}{|llllllll|}
\hline \multicolumn{7}{c|}{$\begin{array}{c}\text { Beeson Apatite } \\
\mathbf{n}=\mathbf{3 4}\end{array}$} \\
\hline & Mean & Max & Min & 2 SD & 2 SD (\%) & Reference & \% Offset \\
& & & & & & & \\
$\mathrm{SiO}_{2}$ & 0 & 0 & 0 & 0 & N/A & 0.11 & -100 \\
$\mathrm{FeO}$ & 0.01 & 0.07 & 0.00 & 0.03 & 218.39 & 0.04 & -62.65 \\
$\mathrm{CaO}$ & 54.99 & 56.99 & 53.55 & 1.77 & 3.22 & 54.31 & 1.25 \\
$\mathrm{P}_{\mathbf{2}} \mathrm{O}_{5}$ & 39.52 & 40.57 & 38.22 & 1.01 & 2.57 & 40.93 & -3.45 \\
$\mathbf{F}$ & 2.38 & 3.69 & 1.57 & 1.12 & 47.10 & 3.67 & -35.04 \\
& & & & & & & \\
Total & 96.10 & 98.30 & 94.50 & 1.93 & 2.01 & 100.14 & -4.04 \\
\hline
\end{tabular}

Table A3.7f. Summary of EPMA data acquired for international standard Beeson Apatite, showing the precision and accuracy of apatite major element analyses. Reference values are from Ingamells (1980). 


\begin{tabular}{|c|c|c|c|c|c|c|c|}
\hline \multicolumn{8}{|c|}{$\begin{array}{l}\text { Engels Amphibole } \\
\qquad n=\mathbf{2 2}\end{array}$} \\
\hline & Mean & Max & Min & $2 \mathrm{SD}$ & 2 SD (\%) & Reference & \% Offset \\
\hline $\mathrm{SiO}_{2}$ & 42.09 & 43.00 & 41.41 & 0.77 & 1.83 & 42.14 & -0.13 \\
\hline $\mathrm{Al}_{2} \mathrm{O}_{3}$ & 11.70 & 12.41 & 11.08 & 0.60 & 5.17 & 12.09 & -3.23 \\
\hline $\mathrm{TiO}_{2}$ & 0.83 & 0.91 & 0.56 & 0.09 & 10.66 & 0.94 & -11.93 \\
\hline $\mathrm{FeO}$ & 18.94 & 19.32 & 18.26 & 0.55 & 2.90 & 19.05 & -0.58 \\
\hline MnO & 0.69 & 0.80 & 0.58 & 0.12 & 16.79 & 0.63 & 9.85 \\
\hline MgO & 8.90 & 9.21 & 8.55 & 0.42 & 4.73 & 8.67 & 2.65 \\
\hline $\mathrm{CaO}$ & 11.55 & 11.75 & 11.38 & 0.16 & 1.40 & 11.56 & -0.12 \\
\hline $\mathrm{Na}_{2} \mathrm{O}$ & 1.60 & 1.69 & 1.46 & 0.11 & 6.58 & 1.63 & -1.68 \\
\hline $\mathrm{K}_{2} \mathrm{O}$ & 0.82 & 0.90 & 0.68 & 0.13 & 15.54 & 0.91 & -10.42 \\
\hline Cl & 0.01 & 0.03 & 0.00 & 0.01 & 69.20 & 0.18 & -92.25 \\
\hline Total & 97.12 & 97.83 & 96.12 & 0.99 & 1.02 & 97.8 & -0.70 \\
\hline
\end{tabular}

Table A3.7g. Summary of EPMA data acquired for international standard Engels Amphibole, showing the precision and accuracy of amphibole major element analyses. Reference values are from Ingamells (1980).

\begin{tabular}{|c|c|c|c|c|c|c|c|}
\hline \multicolumn{8}{|c|}{$\begin{array}{l}\text { Hornblende } \\
n=22\end{array}$} \\
\hline & Mean & Max & Min & $2 S D$ & 2 SD (\%) & Reference & $\%$ Offset \\
\hline $\mathrm{SiO}_{2}$ & 39.50 & 40.30 & 37.56 & 1.40 & 3.55 & 39.54 & -0.11 \\
\hline $\mathrm{Al}_{2} \mathrm{O}_{3}$ & 9.67 & 10.24 & 8.60 & 0.93 & 9.57 & 10 & -3.25 \\
\hline $\mathrm{TiO}_{2}$ & 3.17 & 5.77 & 2.21 & 2.30 & 72.74 & 2.88 & 10.02 \\
\hline $\mathrm{FeO}$ & 26.19 & 27.59 & 25.51 & 1.01 & 3.84 & 26.15 & 0.14 \\
\hline Mno & 0.42 & 0.52 & 0.32 & 0.11 & 26.62 & 0.41 & 2.58 \\
\hline MgO & 4.40 & 4.69 & 4.18 & 0.22 & 4.89 & 4.38 & 0.47 \\
\hline $\mathrm{CaO}$ & 10.74 & 11.02 & 10.00 & 0.57 & 5.29 & 10.79 & -0.48 \\
\hline $\mathrm{Na}_{2} \mathrm{O}$ & 2.08 & 2.27 & 1.84 & 0.20 & 9.40 & 2.02 & 2.84 \\
\hline $\mathrm{K}_{2} \mathrm{O}$ & 1.31 & 1.45 & 0.99 & 0.23 & 17.77 & 1.47 & -10.55 \\
\hline $\mathrm{Cl}$ & 0.14 & 0.17 & 0.11 & 0.02 & 16.80 & 0.18 & -20.86 \\
\hline Total & 97.59 & 98.17 & 96.92 & 0.65 & 0.66 & 97.82 & -0.24 \\
\hline
\end{tabular}

Table A3.7h. Summary of EPMA data acquired for international standard Hornblende, showing the precision and accuracy of amphibole major element analyses. Reference values are from Ingamells (1980). 


\section{Appendix A4: \\ Additional EPMA Information}




\begin{tabular}{|c|c|c|c|c|c|}
\hline \multicolumn{6}{|c|}{ Springwater Olivine } \\
\hline & \multicolumn{3}{|c|}{$\begin{array}{l}\text { Measurement Time } \\
\text { (seconds) }\end{array}$} & \multicolumn{2}{|c|}{$\begin{array}{l}\text { Average Count Rates } \\
\text { (counts per second) }\end{array}$} \\
\hline & & Peak & Background & Calibration 1 & Calibration 2 \\
\hline $\mathbf{S i}$ & 30 & & 15 & 3762.1 & 3787.6 \\
\hline $\mathrm{Fe}$ & 30 & & 15 & 807.2 & 796.7 \\
\hline Mg & 30 & & 15 & 3784.2 & 3834.3 \\
\hline
\end{tabular}

Table A4.1a. Summary of measurement times and average count rates for each element during analyses of olivine standard Springwater Olivine.

Multiple count rates are shown for elements when the olivine standard Springwater Olivine was re-calibrated for additional analyses.

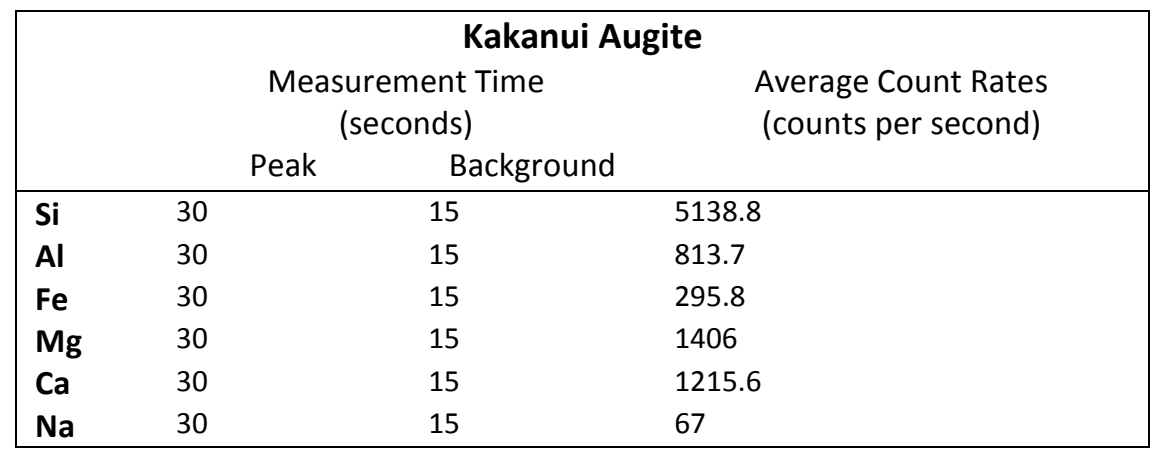

Table A4.1b. Summary of measurement times and average count rates for each element during analyses of clinopyroxene standard Kakanui Augite.

\begin{tabular}{|c|c|c|c|c|}
\hline \multicolumn{5}{|c|}{ Plagioclase NMNH 115900} \\
\hline & \multicolumn{2}{|c|}{$\begin{array}{l}\text { Measurement Time } \\
\text { (seconds) }\end{array}$} & \multicolumn{2}{|c|}{$\begin{array}{l}\text { Average Count Rates } \\
\text { (counts per second) }\end{array}$} \\
\hline & Peak & Background & Calibration 1 & Calibration 2 \\
\hline Si & 30 & 15 & 5213.7 & 3502.5 \\
\hline Al & 30 & 15 & 3332.5 & 2243.5 \\
\hline $\mathrm{Ca}$ & 30 & 15 & 1007.3 & 665.8 \\
\hline $\mathrm{Na}$ & 30 & 15 & 205.4 & 137.6 \\
\hline
\end{tabular}

Table A4.1c. Summary of measurement times and average count rates for each element during analyses of plagioclase standard Plagioclase NMNH 115900.

Multiple count rates are shown for elements when the plagioclase standard Plagioclase NMNH 115900 was recalibrated for additional analyses. 


\begin{tabular}{|lccl|}
\hline & \multicolumn{2}{c|}{$\begin{array}{c}\text { Ilmenite } \\
\text { Measurement Time } \\
\text { (seconds) }\end{array}$} & $\begin{array}{c}\text { Average Count Rates } \\
\text { (counts per second) }\end{array}$ \\
\hline & Peak & Background & \\
\hline $\mathrm{Ti}$ & 30 & 15 & 814.8 \\
$\mathrm{Fe}$ & 30 & 15 & 8094.2 \\
\hline
\end{tabular}

Table A4.1d. Summary of measurement times and average count rates for each element during analyses of ilmenite standard Ilmenite NMNH 115900.

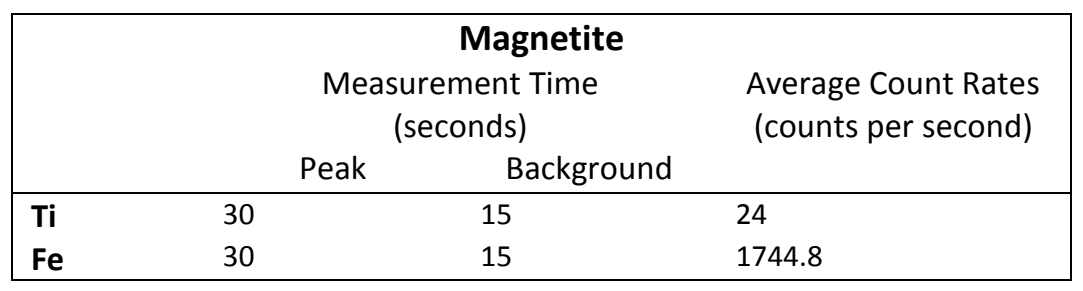

Table A4.1e. Summary of measurement times and average count rates for each element during analyses of magnetite standard Magnetite NMNH 115900.

\begin{tabular}{|c|c|c|c|c|}
\hline & & & eson Apatite & \\
\hline & & Med & $\begin{array}{l}\text { nent Time } \\
\text { nds) }\end{array}$ & $\begin{array}{l}\text { Average Count Rates } \\
\text { (counts per second) }\end{array}$ \\
\hline & & Peak & Background & \\
\hline Si & 30 & & 15 & \\
\hline $\mathbf{P}$ & 30 & & 15 & 1168.8 \\
\hline $\mathbf{F}$ & 30 & & 15 & 230.7 \\
\hline $\mathrm{Ca}$ & 30 & & 15 & 2814.3 \\
\hline
\end{tabular}

Table A4.1f. Summary of measurement times and average count rates for each element during analyses of apatite standard Beeson Apatite. 


\begin{tabular}{|llcl|}
\hline \multicolumn{3}{c|}{$\begin{array}{c}\text { Engels Amphibole } \\
\text { Measurement Time } \\
\text { (seconds) }\end{array}$} & $\begin{array}{c}\text { Average Count Rates } \\
\text { (counts per second) }\end{array}$ \\
\hline & & Peak & Background \\
\hline $\mathbf{S i}$ & 30 & 15 & 2894 \\
$\mathbf{A l}$ & 30 & 15 & 771.4 \\
$\mathbf{T i}$ & 30 & 15 & 83.2 \\
$\mathbf{F e}$ & 30 & 15 & 623.1 \\
$\mathbf{M n}$ & 30 & 15 & 6.5 \\
$\mathbf{M g}$ & 30 & 15 & 470.5 \\
$\mathbf{C a}$ & 30 & 15 & 1579.6 \\
$\mathbf{N a}$ & 30 & 15 & 46.4 \\
$\mathbf{K}$ & 30 & 15 & 48.2 \\
\hline
\end{tabular}

Table A4.1g. Summary of measurement times and average count rates for each element during analyses of apatite standard Engels Amphibole. 